\title{
Site U1336
}

\author{
Expedition 320/321 Scientists ${ }^{2}$
}

\section{Chapter contents}

Background and objectives. . . . . . . . 1

Science summary.................. 3

Operations.................6

Lithostratigraphy.............. 7

Biostratigraphy ............... 9

Paleomagnetism ............... 13

Geochemistry ................. 14

Physical properties .............. 15

Stratigraphic correlation and composite

section................... 17

References.................... 18

Figures................... 20

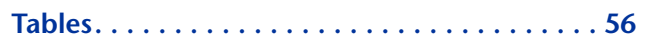

'Expedition 320/321 Scientists, 2010. In Pälike, H., Lyle, M., Nishi, H., Raffi, I., Gamage, K., Klaus, A., and the Expedition 320/321 Scientists, Proc. IODP, 320/321: Tokyo (Integrated Ocean Drilling Program Management International, Inc.). doi:10.2204/iodp.proc.320321.108.2010 'Expedition 320/321 Scientists' addresses.

\section{Background and objectives}

Integrated Ocean Drilling Program Site U1336 (site survey PEAT$5 \mathrm{C} ; 7^{\circ} 42.067^{\prime} \mathrm{N}, 128^{\circ} 15.253^{\prime} \mathrm{W} ; 4286$ meters below sea level [mbsl]) (Fig. F1; Table T1) is in the central area drilled during the Pacific Equatorial Age Transect (PEAT) program (Expedition 320/ $321)$. Site U1336 ( 32 Ma crust) is between Site U1334 $\sim 10 \mathrm{~km}$ to the west and Site U1335 330 km to the southeast and $\sim 100 \mathrm{~km}$ to the west of Deep Sea Drilling Project (DSDP) Site 78. Site U1336 is also $\sim 30 \mathrm{~km}$ north of the center of the Clipperton Fracture Zone. The site survey data (Lyle et al., 2006; Pälike et al., 2008) show that Site U1336 is on abyssal hill topography draped with thick sediment (Fig. F2). The fabric of the abyssal hills is oriented slightly west of due north.

Water depth in the vicinity of Site U1336 is relatively shallow for the age of the crust, between 4200 and $4400 \mathrm{~m}$. Surprisingly, the crust south of the Clipperton Fracture Zone is only $100 \mathrm{~m}$ deeper than the crust north of the zone, despite a water depth of nearly $5 \mathrm{~km}$ in the middle of the fracture zone trace. A few oblique ridges and depressed topography occur in the south of the survey area, showing some interaction between the fracture zone and the Site U1336 region. The site is thickly covered with sediment (300-400 ms two-way traveltime [TWT]) (Fig. F2) and has a very thin layer of recent to middle Miocene sediment, with frequent sediment erosion on flanks of abyssal hills. Based on correlation to the Neogene central equatorial Pacific seismic stratigraphy of Mayer et al. (1985) and the Paleogene equatorial Pacific stratigraphy of Lyle et al. (2002), we estimated $\sim 120 \mathrm{~m}$ of Oligocene sediment for an average Oligocene sedimentation rate of $13 \mathrm{~m} / \mathrm{m}$.y., assuming a crustal age of $32 \mathrm{Ma}$. The total sediment thickness, using the velocity-depth conversion for DSDP Site 574 (Mayer et al., 1985) was estimated as $253 \mathrm{~m}$ prior to drilling.

Based on stage-pole reconstructions of Pacific plate motion, observations of basement age from previous drilling sites, and magnetic anomaly maps (Cande et al., 1989), we estimated that Site U1336 is on 32 Ma crust. The best control on age is information from Site 78, $100 \mathrm{~km}$ east of Site U1336. The base of Site 78 reaches the lower Oligocene.

Site U1336 targets the Oligocene and is on lower Oligocene crust. This interval of time is noted by heavy oxygen isotopes and a relatively deep calcium carbonate compensation depth (CCD) (Zachos et al., 2001a, 2001b; Pälike et al., 2006a, 2006b; Lyle, 2003). 
There was probably ice on Antarctica during this interval, but not the large ice sheets found there in the middle Miocene. There is no compelling evidence for ice sheets in the Northern Hemisphere during the Oligocene and early Miocene. Thus, there was apparently a relatively low global ice volume, relatively cold bottom waters, a relatively cold South Pole, and a relatively warm North Pole. This scenario of a "one cold pole" world has given rise to speculation on the impact of interhemispheric temperature imbalance on pole to Equator temperature gradients and on the symmetry of the global wind systems. The extent to which such an imbalance may have affected trade winds, the position of the intertropical convergence zone, and seasonal shifts in this zone should be seen in the wind-driven currents of the equatorial region.

Older low-resolution DSDP data (Hays et al., 1972) indicate relatively high but variable sediment accumulation rates during the Oligocene and better carbonate preservation south of the Equator (van Andel, 1975). In the Ocean Drilling Program (ODP) Leg 199 equatorial transect (Lyle, Wilson, Janecek, et al., 2002), the highest accumulation rates encountered (>15 m/m.y.) occurred in the lower part of the Oligocene, but these were in sites north of the Oligocene Equator or on relatively old (and therefore deep) crust. Thus we expected better fossil preservation and a thicker carbonate section at the Oligocene Equator.

Studies of Oligocene sections from Leg 199 (Lyle, Wilson, Janecek, et al., 2002) and from other ODP sites (e.g., Paul et al., 2000; Zachos et al., 2001b) indicate the presence of strong eccentricity and obliquity cycles in carbonate preservation and suggest a strong (southern) high-latitude influence on the carbonate record. These cycles are leading to the development of an orbitally tuned timescale that reaches to the base of the Oligocene (Pälike et al., 2006b). Such a timescale makes it possible to develop a very detailed picture of equatorial geochemical fluxes and of the degree of variability in the equatorial system of the Oligocene.

Site U1336 also targets paleoceanographic events in the late Oligocene and into the early Miocene, including the climatically significant OligoceneMiocene transition and the recovery from the Mi-1 glaciation event. In conjunction with Sites U1335 and U1337, it was also sited to provide a latitudinal transect for early Miocene age slices. At the end of the Oligocene there is a significant multimillion year long rise in the oxygen isotope record (supplementary material in Pälike et al., 2006b), which is closely followed by a relatively short, sharp increase in oxygen isotope values that has been interpreted as a major glacial episode (Mi-1) (Zachos et al., 1997, 2001a, 2001b; Pälike et al., 2006a, 2006b) and correlated to a pronounced drop in sea level (Miller et al., 1991). This event is very close to the Oligocene/Miocene boundary and has now been astronomically age calibrated in several ocean basins (Shackleton et al., 2000; Billups et al., 2004; Pälike et al., 2006a). Although there are clear periodic isotopic signals indicating major changes in ice volume, ocean temperatures, and/or ocean structure, this biostratigraphic boundary has always been somewhat of an enigma. Unlike the major changes in the isotopic stratigraphy, the biostratigraphies of planktonic microfossils show very little change at all. In fact it is one of the most difficult epoch boundaries to pick using only microfossil biostratigraphies.

Given the Clipperton Fracture Zone geographical constraint, we positioned Site U1336 as close as possible to the estimated paleoequatorial position at the target age in order to maximize the time that the drill site remains within the equatorial zone (i.e., $\pm 2^{\circ}$ of the Equator), to allow for some southward bias of the equatorial sediment mound relative to the hotspot frame of reference (Knappenberger, 2000) and to place the interval of maximum interest above the basal hydrothermal sediments. We located the site using the digital age grid of seafloor age from Müller et al. (1997), heavily modified and improved with additional magnetic anomaly picks from Petronotis (1991) and Petronotis et al. (1994) and DSDP/ODP basement ages. For this grid, each point is then backrotated in time to zero age, using the fixed-hotspot stage-poles from Koppers et al. (2001) and Engebretson et al. (1985) and the paleopole data from Sager and Pringle (1988). From the backtracked latitudes for each grid point we then obtained the paleoequator at the crustal age by contouring of latitudes.

One of the common objectives of the PEAT program for all sites is to provide a limited depth transect for several Cenozoic key horizons, such as the OligoceneMiocene transition (Shackleton et al., 2000; Pälike et al., 2006a; Zachos et al., 2001b). For the OligoceneMiocene transition objective, Sites U1334-U1337 will form a combined depth transect for OligoceneMiocene time. Site U1336 has an estimated crustal paleodepth of $\sim 3.7 \mathrm{~km}$ during the OligoceneMiocene transition, $\sim 300 \mathrm{~m}$ deeper than Site U1335 and $\sim 500 \mathrm{~m}$ shallower than Site U1334.

Expedition 320/321 drill sites all have in common the objective to improve and extend the extensive intercalibrated bio-, magneto-, chemo-, and astronomical stratigraphies for the Cenozoic (e.g., Shackleton et al., 2000; Pälike et al., 2006b).

Seismic reflection data (Fig. F2) (Pälike et al., 2008; Lyle et al., 2006) allowed us to optimize the Site 
U1336 position on seismic Line PEAT-5C-sl-6, west of the intersection with the north-south Cross-line PEAT-5C-sl-1, to better image basement and obtain a more expanded lower sediment section. We estimated sediment thickness using interval velocities published for Site 574 by Mayer et al. (1985), which drilling determined later to underestimate the basal interval velocities and therefore total sediment thickness. Based upon correlation to the central equatorial Pacific seismic stratigraphy of Mayer et al. (1985), middle Miocene sediment has been exposed.

Site survey piston Core RR0603-7JC was taken east of Site U1336 (Fig. F1B). The cores recovered mottled brown to light brown alternating carbonates and siliceous biogenic sediments. The age at the base of this core is $\sim 13 \mathrm{Ma}$, based on radiolarian biostratigrapy.

\section{Science summary}

Two holes were cored at Site U1336 (proposed Site PEAT-5C; $7^{\circ} 42.067^{\prime} \mathrm{N}, 128^{\circ} 15.253^{\prime} \mathrm{W} ; 4286 \mathrm{mbsl}$ ) (Fig. F1; Table T1) targeting paleoceanographic events in the late Oligocene and into the Miocene, including a focus on the Oligocene-Miocene transition and the recovery of the Mi-1 glaciation event (Zachos et al., 2001b; Pälike et al., 2006b). In conjunction with Sites U1335 and U1337, Site U1336 was also designed to provide a latitudinal transect for early Miocene age slices. Site U1336 provides data toward a depth transect across the late Oligocene and Miocene that allow us to verify and apply a previous astronomical age calibration from Site 1218 (Pälike et al., 2006a).

At Site U1336, advanced piston corer (APC) cores were taken from the seafloor to $184.8 \mathrm{~m}$ (Cores 320U1336A-1H through $21 \mathrm{H}$ ) and $173.6 \mathrm{~m}$ (Cores 320U1336B-1H through 20H). Nonmagnetic core barrels were used for Cores 320-U1336A-1H through $16 \mathrm{H}$ and Cores $320-\mathrm{U} 1336 \mathrm{~B}-1 \mathrm{H}$ through $16 \mathrm{H}$ and steel barrels were used for all other cores. Two hard layers, one at $\sim 121 \mathrm{~m}$ core depth below seafloor (CSF) (Cores 320-U1336A-14H and 320-U1336B-14H) and one at $135 \mathrm{~m}$ CSF (Core 320-U1336B-16H) caused core loss and prevented the development of a continuous sediment section. Extended core barrel (XCB) cores (320-U1336A-22X through 35X) were taken from 184.8 to $302.9 \mathrm{~m}$ CSF in Hole U1336A. We stopped coring before reaching the basement objective because of decreasing rates of penetration, relatively low recovery, and the possibility of obtaining a stratigraphically complete Miocene section by allocating the remaining operational time during Expedition 320 to Hole U1336B.

At Site U1336, $\sim 300 \mathrm{~m}$ of pelagic sediments are divided into three major lithologic units (Fig. F3). The sediments are composed mainly of nannofossil oozes, nannofossil chalks, and chert. The lower to middle Miocene sedimentary sequence of Unit I (0$74.54 \mathrm{~m} \mathrm{CSF}$ ) contains more radiolarians, clay, foraminifers, and diatoms relative to the lower Miocene to lower Oligocene sediments below $\sim 70 \mathrm{~m}$ CSF. Subtle changes in the relative proportions of these minor components produce meter-scale dark-light color cycles and two diatom-rich layers. Numerous rounded fragments of pumice occur throughout this unit.

Unit II (74.50-189.50 m CSF) is dominated by nannofossil ooze. Sediment color changes downhole from pale yellow to light greenish gray at $92 \mathrm{~m}$ CSF. Below this boundary, the color of Unit II alternates between light greenish gray and white to $184.80 \mathrm{~m}$ CSF. Oxidation-reduction reactions are responsible for the observed vivid colors and pore water chemistry changes, likely fueled by varied availability of organic carbon. Occasional thin chert layers were encountered below $120 \mathrm{~m}$ CSF in Unit II. Mainly broken chert fragments were recovered, except for a small in situ chert fragment at $159.6 \mathrm{~m}$ CSF in Section 320-U1336B-18H-4, $106 \mathrm{~cm}$. More abundant chert layers are common in the lower third of the recovered sequence.

Unit III (189.5-299.6 m CSF) was only recovered in Hole U1336A. The dominant lithologies of this unit are light greenish gray and white nannofossil chalk with light greenish gray millimeter-scale color banding and chert layers. The chert shows many different colors including black, dark greenish gray, very dark greenish gray, dark gray, olive-yellow, dark brown, and pink. The Unit II-III transition is identified by the uppermost common occurrence of chert. Below 289 m CSF, nannofossil chalk contains increasing amounts of micrite and the cherts vary in color. The lowermost cherts are olive-yellow, then pink, and, finally, dark brown at the base. The chalk changes color to white below $298.54 \mathrm{~m} \mathrm{CSF}$. $\mathrm{CaCO}_{3}$ contents remain $>88 \mathrm{wt} \%$ in the chalk layers. Igneous basement was not recovered at Site U1336.

All major microfossil groups were found in sediments from Site U1336, representing a complete biostratigraphic succession at the shipboard sample resolution level of middle Miocene to lower Oligocene sediments. They provide a coherent, high-resolution biochronology through a complete sequence (Fig. F3). Calcareous nannofossils are moderately to poorly preserved throughout the succession. There appears to be a complete sequence of nannofossil zones from Zone NN6 (middle Miocene) through NP22 (lower Oligocene), except for Zone NN3, which could not be resolved. Planktonic foraminifers are present throughout the succession ranging from 
Zones N12 through O1. They are moderately well preserved in the Miocene and less well preserved in the Oligocene.

Benthic foraminifers are present throughout the section, although abundances are overall quite low. The preservation of tests is moderate in the upper part of Site U1336 (Samples 320-U1336A-1H-CC through 19H-CC, 8.22-170.63 m CSF, and 320-U1336B-1HCC through 20H-CC, 1.68-174.01 m CSF) but deteriorates below this level. The Oligocene to middle Miocene benthic foraminifer assemblage is relatively diverse and indicates oligotrophic lower bathyal to abyssal paleodepths.

The Oligocene/Miocene boundary is placed between the first occurrence of Paragloborotalia kugleri (23.0 Ma) and the extinction of Sphenolithus delphix (23.1 Ma). The former occurs between Samples 320-U1336A$16 \mathrm{H}-\mathrm{CC}$ and $17 \mathrm{H}-2,38-40 \mathrm{~cm}(142.96 \mathrm{~m} \mathrm{CSF})$ and Samples 320-U1336B-16H-1, 52-54 cm, and $17 \mathrm{H}-3$, $80-82 \mathrm{~cm}$ (137.72 m CSF). The top of $S$. delphix is recognized between Samples 320-U1336A-17X-2, $90 \mathrm{~cm}$, and 17X-4, $90 \mathrm{~cm}$ (145.9 $\mathrm{m} \mathrm{CSF})$, and between Samples 320-U1336B-16H-CC and 17H-1, $150 \mathrm{~cm}$ (137.56 m CSF).

The radiolarian stratigraphy at Site U1336 spans the interval from just above the Zone RN6/RN5 boundary (middle Miocene) to the upper part of Zone RP22 (upper Oligocene) at $\sim 170 \mathrm{~m}$ CSF. Below this level the sediments are barren of radiolarians. Above this level the assemblages tend to have good to moderate preservation with intermittent intervals of good preservation in Zones RN3 and RN4 (lower to middle Miocene). The downsection decrease in preservation and ultimate disappearance of the radiolarians below Core 320-U1336A-19H appears to be associated with dissolution and reprecipitation of the biogenic silica as intergranular cement and as chert.

Diatom stratigraphy in Hole U1336B spans the interval from just above the Cestodiscus peplum zone (middle Miocene) in Core 320-U1336B-1H to the lowermost part of the Crucidenticula nicobarica zone (upper lower Miocene) in Core 320-U1336B-7H. Below Sample 320-U1336B-7H-CC, the sediments are barren of diatoms. Above this level the valves tend to be mostly poorly preserved. Sample 320-U1336B-1HCC contains the highest diversity with Cestodiscus pulchellus as dominant component, accompanied by Cavitatus jouseana and Thalassiosira yabei. Fragments of the large centric diatom Ethmodiscus are present in the upper part of Hole U1336B.

Paleomagnetic measurements were conducted on archive-half sections of 21 APC cores from Hole U1336A and 20 APC cores from Hole U1336B. Measurements of natural remanent magnetization
(NRM) above $\sim 80 \mathrm{~m}$ CSF in Holes U1336A and U1336B indicate moderate magnetization intensities $\left(\sim 1 \times 10^{-3} \mathrm{~A} / \mathrm{m}\right)$ with a patchy but generally weak viscous remanent magnetization (VRM) or isothermal remanent magnetization (IRM) drilling overprint. Polarity reversal sequences are clearly recognized (Fig. F3). Demagnetization data from discrete samples above $\sim 80 \mathrm{~m} \mathrm{CSF}$ indicate that the characteristic remanent magnetization of the sediments is identified at the 10-20 mT demagnetization steps. The reversals pattern can be correlated with the geomagnetic polarity timescale (GPTS) from the base of Chrons C5r to C6n ( 12 to $19 \mathrm{Ma})$.

Below $\sim 80 \mathrm{~m}$ CSF, a zone of diagenetic alteration involving dissolution of remanence carriers reduces remanence intensities after alternating-field (AF) demagnetization of $20 \mathrm{mT}$ to values close to magnetometer noise level in the shipboard environment $\left(\sim 1 \times 10^{-5} \mathrm{~A} / \mathrm{m}\right)$. In this zone, sediment magnetizations have been partly or entirely overprinted during the coring process and remanence inclinations are sometimes steep after AF demagnetization at peak fields of $20 \mathrm{mT}$. At $\sim 130-140 \mathrm{~m}$ CSF (Cores 320U1336A-15H through $16 \mathrm{H}$ and $320-\mathrm{U} 1336 \mathrm{~B}-15 \mathrm{H})$ and below $\sim 160 \mathrm{~m}$ CSF (Cores 320-U1336A-19H through $21 \mathrm{H}$ and $320-\mathrm{U} 1336 \mathrm{~B}-18 \mathrm{H}$ through $20 \mathrm{H}$ ), polarity reversals are apparently present but the inclinations are steep (as much as $80^{\circ}$ ), indicating that the drilling overprint has not been effectively removed during shipboard demagnetization.

A complete physical property program was conducted on whole cores, split cores, and discrete samples. Whole-Round Multisensor Logger (WRMSL) (gamma ray attenuation [GRA] bulk density, magnetic susceptibility, $P$-wave velocity, and electrical noncontact resistivity), thermal conductivity, and natural gamma radiation (NGR) measurements comprised the whole-core measurements. Compressional wave velocity measurements on split cores and moisture and density (MAD) analyses on discrete core samples were made at a frequency of 1 per undisturbed section in Cores 320-U1336A-1H through $35 \mathrm{X}$. Compressional wave velocities were measured toward the bottom of sections. MAD analyses were located $10 \mathrm{~cm}$ downsection from carbonate analyses (see "Geochemistry"). Lastly, the Section Half Multisensor Logger (SHMSL) was used to measure spectral reflectance on archive-half sections. Physical properties measurements on whole-round sections and samples from split cores reflect the differences among lithologies drilled at Site U1336 (Fig. F3). Nannofossil ooze with varying amounts of clay, radiolarians, and diatoms makes up lithologic Unit I and is characterized by high-amplitude and highfrequency variations in bulk density, magnetic sus- 
ceptibility, NGR, and color reflectance. Magnetic susceptibility is highest in Unit I, with values ranging from $5 \times 10^{-5}$ to $30 \times 10^{-5}$ SI. NGR is also high in this unit, with values to $56 \mathrm{cps}$ near the seafloor. Wet bulk densities are lowest in Unit I, with values ranging from 1.4 to $1.7 \mathrm{~g} / \mathrm{cm}^{3}$. Porosity is highest in this interval, ranging from $65 \%$ to $80 \%$. The grain density of most of the sediments of Unit I, as well as Units II and III, ranges from 2.6 to $2.9 \mathrm{~g} / \mathrm{cm}^{3}$, reflecting the dominance of carbonate constituents at Site U1336. The sediment velocity in Unit I is low, averaging $1500 \mathrm{~m} / \mathrm{s}$. The color reflectance of Unit I is marked by luminance $\left(\mathrm{L}^{*}\right)$ values that are slightly lower and more variable than values determined for sediments in Units II and III.

Below Unit I, a more uniform increase in wet bulk density and decrease in porosity in Units II and III reflects the increasing compaction of the sediments. A slight step increase in wet bulk density marks the transition between Units II and III. In Unit III wet bulk density and porosity average $1.9 \mathrm{~g} / \mathrm{cm}^{3}$ and $51 \%$, respectively. Magnetic susceptibility and NGR are low and nearly uniform in Units II and III. Magnetic susceptibility is typically below $5 \times 10^{-5} \mathrm{SI}$, and NGR is $\sim 2$ cps. Lower clay abundance in Unit II is marked by an increase in $\mathrm{L}^{*}$ at the boundary between Units I and II. At $92 \mathrm{~m} \mathrm{CSF}$, within Unit II, sharp decreases in the $a^{*}$ and $b^{*}$ reflectance parameters mark the change in sediment color from pale yellow to greenish gray. One of the most pronounced changes in physical properties at Site U1336 is the sharp increase in velocity that accompanies the change from nannofossil ooze to nannofossil chalk at the boundary between Units II and III. The velocity at the base of Unit II is $\sim 1700 \mathrm{~m} / \mathrm{s}$. Below $190 \mathrm{~m}$ CSF, in Unit III, the rate at which velocity increases with depth increases, ultimately reaching $\sim 2200 \mathrm{~m} / \mathrm{s}$ at $290 \mathrm{~m} \mathrm{CSF}$, near the base of Hole U1336A.

Special Task Multisensor Logger (STMSL) data were collected at $5 \mathrm{~cm}$ intervals from Hole U1336B and compared to the WRMSL data obtained at $2.5 \mathrm{~cm}$ resolution from Hole U1336A during Expedition 320. Features in the magnetic susceptibility and gamma ray attenuation density are well aligned between Holes U1336A and U1336B to a depth of 94 m core composite depth below seafloor (CCSF-A; see "Core composite depth scale" in the "Methods" chapter). Below $94 \mathrm{~m}$ CCSF-A, the magnetic susceptibility signal drops to very low values but the density data are good enough to sustain a correlation to interval 320-U1334B-14H-4, $122 \mathrm{~cm}$. At this point (138.50 m CCSF-A) sediments recovered in both holes are disturbed.
Paleomagnetic reversals were used to calculate the average linear sedimentation rate (LSR) for the upper $74 \mathrm{~m}$ of the section at Site U1336 on the corrected core composite depth below seafloor (CCSF-B; see "Corrected core composite depth scale" in the "Methods" chapter) depth scale. Below $74 \mathrm{~m}$ CSF only biostratigraphic datums were used to calculate the average LSR. The LSR at Site U1336 decreases from $15 \mathrm{~m} / \mathrm{m}$.y. in the upper Oligocene to $12 \mathrm{~m} / \mathrm{m}$.y. in the lower Miocene and stays relatively constant at $9 \mathrm{~m} / \mathrm{m}$.y. in the remainder of the section.

Standard geochemical analyses of pore water and organic and inorganic sediment properties were undertaken on Site U1336 samples. Alkalinity is relatively constant at values $>2.5 \mathrm{mM}$ in the upper $110 \mathrm{~m} \mathrm{CSF}$, with a pronounced decline to $1 \mathrm{mM}$ by $170 \mathrm{~m}$ CSF. Sulfate concentrations decrease with depth to values as low as $22 \mathrm{mM}$. Dissolved manganese has a broad peak in the depth range from $\sim 25$ to $120 \mathrm{~m} \mathrm{CSF}$, and dissolved iron appears then peaks below $100 \mathrm{~m}$ CSF. The increase of dissolved iron occurs where $\mathrm{Mn}$ decreases downhole. Concentrations of dissolved silicate increase with depth from $<400$ to $800 \mu \mathrm{M}$.

\section{Highlights}

\section{Miocene sedimentary section and cyclic sedimentation}

One of the highlights from Site U1336 is the recovery of a thick Miocene carbonate section from the central equatorial Pacific, one of the high-priority objectives of the PEAT program. We recovered the complete early Miocene sequence (7.1 m.y. duration) in a $\sim 110 \mathrm{~m}$ thick section, with a sedimentation rate of $12 \mathrm{~m} / \mathrm{m} . \mathrm{y}$. and the middle Miocene sequence (4.4 m.y. duration) in a $\sim 45 \mathrm{~m}$ thick interval with a sedimentation rate of $\sim 21 \mathrm{~m} / \mathrm{m}$.y. These high sedimentation rates will facilitate the study of paleoceanographic processes at unprecedented resolution for the equatorial Pacific.

The obvious variations of both color and biogenic composition within nannofossil oozes represent cyclic fluctuations of CCD and upwelling intensity during the middle Miocene through early Miocene. The variable lithology also results in the variations of many petrophysical signals of physical properties including $\mathrm{L}^{*}, \mathrm{~b}^{*}$, magnetic susceptibility, NGR, and GRA bulk density.

\section{Oligocene-Miocene transition and depth transects}

Site U1336 was planned as part of a latitudinal transect for early Miocene age slices and the PEAT OligoceneMiocene depth transect compound in conjunction with Sites U1335 and U1337. The Miocene sequence 
at these sites includes the critical intervals of the Mi1 glaciation and middle Miocene ice sheet expansion (Holbourn et al., 2005; Zachos et al., 2001b; Pälike et al., 2006b). The dominant lithologies of nannofossil ooze and chalk at Sites U1336 and U1335, with good preservation of calcareous microfossils, will allow us to achieve the prime objective for this site.

The Oligocene-Miocene transition in Hole U1336A occurs in homogeneous nannofossil ooze within the alternations of white and light greenish gray ooze. The same alternating sequence is observed above the Oligocene-Miocene transition at Site U1334. Biostratigraphy reveals that the Oligocene/Miocene boundary exists between 142.96 and $145.9 \mathrm{~m} \mathrm{CSF}$ at Site U1336; this will allow the high-resolution study of this critical interval.

\section{Geochemical front}

Site U1336 recovered an interval of greenish gray carbonates that exhibit a distinct peak in dissolved Fe concentrations in pore water with similar characteristics as geochemical alteration fronts at Sites U1334 and U1335. At Site U1336, this zone is 200 m thick. The remanent magnetization intensity is very weak in most parts of this section (80-180 m CSF). High dissolved $\mathrm{Fe}$ and $\mathrm{Mn}$ concentrations in pore water are caused by changes in the oxidation state of the sediments. The oxidation-reduction reactions are likely fueled by variable availability of organic carbon in the sediments. This site may provide the opportunity to study organic matter degradation.

Site U1336 migrated from south to north through the equatorial belt of high productivity. Based on paleolatitude reconstructions these geochemical alteration fronts can be mapped to similar equatorial positions between Sites U1334 and U1335, roughly between the Equator and $\sim 4^{\circ} \mathrm{N}$.

\section{Chert formation in the early Oligocene}

The sequence at Site U1336 includes barren intervals of radiolarian fossils and many thin intercalated chert layers and fragments. The radiolarians decrease in preservation downsection and disappear below Core 320-U1336A-19H. Instead, the sediments contain several chert fragments. Some inferred chert layers occur at 120-140 m CSF and blocked APC penetration. Below $\sim 190 \mathrm{~m} \mathrm{CSF}$, various colored chert layers and fragments occurred within the cores. The chert frequently contains foraminifer tests, reflecting diagenetic process of dissolution and reprecipitation of the biogenic silica.

The dissolution of biogenic silica is the source of porcellanite and chert and, on crust younger than $65 \mathrm{Ma}$, almost all cherts in the Pacific Ocean lie $<150 \mathrm{~m}$ above basement. Although we did not recover basement rocks at this site, the sediments became hard, lithified limestones and the drilled section is probably close to basement. The dissolution of silica in the basal sedimentary section is likely associated with the circulation of warm hydrothermal waters in the upper oceanic crust that extend into the lower sediments where they are cut by fractures and faults (Moore, 2008a, 2008b). This site will provide information on chert formation in the equatorial Pacific regions.

\section{Operations}

Times for Site U1336 are given in local ship time, which was Universal Time Coordinated (UTC) -9 h.

\section{Transit to Site U1336}

The $185 \mathrm{nmi}$ transit from Site U1335 to Site U1336 took $17.8 \mathrm{~h}$ at an average speed of $10.4 \mathrm{kt}$.

\section{Site U1336}

\section{Hole U1336A}

The ship slowed as it approached Hole U1336A and was in dynamic positioning mode at $1545 \mathrm{~h}$ on 22 April 2009. Once the ship was stabilized over the new site, the drill string was deployed and the bit positioned $5 \mathrm{~m}$ shallower than the corrected precision depth recorder depth of $4300.4 \mathrm{~m}$ drilling depth below rig floor (DRF). Hole U1336A was spudded with the APC at $0135 \mathrm{~h}$ on 23 April. The seafloor depth estimated from recovery in the first core was $4296.9 \mathrm{~m}$ DRF (4285.3 mbsl) (Table T1).

APC Cores 320-U1336A-1H through $21 \mathrm{H}$ were taken from 0 to $184.8 \mathrm{~m} \mathrm{CSF}$ and recovered $190.2 \mathrm{~m}$ (103\%) (Table T1). Nonmagnetic core barrels were used to obtain Cores 320-U1336A-1H through 16H; steel barrels were used for all other cores. Three cores $(320-\mathrm{U} 1336 \mathrm{~A}-14 \mathrm{H}, 16 \mathrm{H}$, and $21 \mathrm{H})$ only partially stroked and were advanced by recovery. A hard layer at 124 DSF prevented Core 320-U1336A-14H from achieving a full stroke; the layer was $\sim 0.5 \mathrm{ft}$ thick and was not recovered. Based on how it drilled, we inferred it may have been chert. The last piston core (320-U1336A-21H) required drilling over to free the barrel from the formation.

Cores 320-U1336A-22X through 35X were taken from 184.8 to $302.9 \mathrm{~m} \mathrm{CSF}$ and recovered $69.0 \mathrm{~m}$ (58\%). We stopped coring before reaching the basement objective because of decreasing rates of penetration (as low as $\sim 3 \mathrm{~m} / \mathrm{h}$ for Cores $320-\mathrm{U} 1336 \mathrm{~A}-34 \mathrm{X}$ and $35 \mathrm{X}$ ), relatively low recovery, and the possibility of obtaining a stratigraphically complete Miocene section by coring in a second hole. We pulled out of 
the hole and the bit cleared the seafloor at $0400 \mathrm{~h}$ on 25 April. We offset the ship $25 \mathrm{~m}$ south of Hole U1336A.

\section{Hole U1336B}

After positioning the bit at $4284 \mathrm{~m}$ DRF (5 m shallower than in Hole U1336A), we started coring in Hole U1336B at $0540 \mathrm{~h}$ on 25 April. Based on recovery in the first core, the seafloor depth was $4298.1 \mathrm{~m}$ DRF (4286.5 mbsl). Cores 320-U1336B-1H through $20 \mathrm{H}$ were taken from 0 to $173.9 \mathrm{~m} \mathrm{CSF}$ and recovered $179.6 \mathrm{~m}(103 \%)$. Nonmagnetic core barrels were used for Cores 320-U1336B-1H through 16H; steel barrels were used for the others. Core 320-U1336B$16 \mathrm{H}$ only achieved a partial stroke and was advanced by recovery. Once coring was completed, the drill string was pulled out of the hole with the bit clearing the seafloor at $0400 \mathrm{~h}$ on 26 April. Once all drilling equipment was secured, the vessel departed for Honolulu, Hawaii, at 1315 h on 26 April.

\section{Transit to Honolulu, Hawaii}

The $1954 \mathrm{nmi}$ transit from Site U1336 to Honolulu, Hawaii took 7.8 days at an average speed of $10.4 \mathrm{kt}$. At 2400 on 27 April 2009, the shipboard clocks were set back one hour so that ship local time was UTC $10 \mathrm{~h}$ (Hawaii Standard Time). Expedition 320 concluded with the first line ashore at $0736 \mathrm{~h}$ on 4 May.

\section{Lithostratigraphy}

Drilling at Site U1336 recovered a $\sim 300 \mathrm{~m}$ thick section of pelagic sediments (Fig. F4). The sedimentary sequence at Site U1336 is divided into three lithologic units (Fig. F4; Table T2). Unit I (0-74 m CSF) is composed of nannofossil ooze of Miocene age that displays submeter-scale alternations of white (10YR 8/1) to brown (10YR 5/3) nannofossil oozes with varying amounts of radiolarians, foraminifers, diatoms, and clay as minor constituents. Two white (10YR 8/1) diatom nannofossil oozes (Samples 320-U1336A$5 \mathrm{H}, 22-36 \mathrm{~cm}$, and $6 \mathrm{H}-2,87-92 \mathrm{~cm}$ ) are present within Unit I. These intervals were not observed in Hole U1336B. Unit II (74-189 m CSF) consists of $\sim 115 \mathrm{~m}$ thick nannofossil ooze of early Miocene to late Oligocene age with very weak magnetic susceptibility and vivid color changes. Sediment color changes downhole from pale yellow $(2.5 \mathrm{Y} 8 / 2)$ to light greenish gray (10Y 8/1) at $92 \mathrm{~m}$ CSF. Below this boundary, the coloration of the Unit II nannofossil oozes alternates between light greenish gray (10Y $8 / 1$ ) and white $(\mathrm{N} 8 /)$ to $184.80 \mathrm{~m} \mathrm{CSF}$. Unit III is composed of light greenish gray (10GY 7/1) nannofossil chalks with interbedded greenish gray (10GY 6/1) to black (10YR 2/1), olive-yellow (2.5Y
6/6), and pink (7.5YR 7/3) chert layers (189.50$299.6 \mathrm{~m} \mathrm{CSF}$ ) of Oligocene age. Units II and III have similar color alternations with occasional sharply defined packets of light greenish gray (5G 8/1) color bands below $120.86 \mathrm{~m}$ CSF.

Lithologic units and boundaries (Table T2) are defined by differences in lithology, physical property data, and calcium carbonate $\left(\mathrm{CaCO}_{3}\right)$ content as measured by coulometry (see "Geochemistry"). Lithologic differences, based on both visual core description and smear slide analysis, reflect varying distributions of biogenic components such as nannofossils, radiolarians, diatoms, and clay-sized lithogenic material (Fig. F4; see "Site U1336 smear slides" in "Core descriptions"). Lithologic descriptions are based on sediments recovered in Holes U1336A and U1336B. Sediments from Hole U1336A were described by the scientific party during Expedition 320, whereas those from Hole U1336B were examined and described by the Expedition 321 scientific party.

\section{Unit I}

Intervals: $320-\mathrm{U} 1336 \mathrm{~A}-1 \mathrm{H}-1,0 \mathrm{~cm}$, through $8 \mathrm{H}-7$, $5 \mathrm{~cm} ; 320-\mathrm{U} 1336 \mathrm{~B}-1 \mathrm{H}-1,0 \mathrm{~cm}$, through $9 \mathrm{H}-5$, $84 \mathrm{~cm}$

Depths: Hole U1336A = 0-73.05 m CSF; Hole $\mathrm{U} 1336 \mathrm{~B}=0-75.14 \mathrm{~m} \mathrm{CSF}$

Age: middle to lower Miocene

Lithology: nannofossil ooze and diatom nannofossil ooze

Major lithologies in Unit I are white (10YR 8/1) to brown (10YR 5/3) nannofossil ooze. The unit is characterized by alternating submeter-scale light and dark bands of nannofossil ooze. Based on smear slides, the darker bands contain greater amounts of radiolarians and/or clay and some of the white bands are nannofossil ooze with foraminifers (Figs. F5, F6). The alternating white to brown sequence is punctuated by two white (10YR 8/1) layers of diatom nannofossil ooze (Samples 320-U1336A-5H-2, 22$36 \mathrm{~cm}$, and $6 \mathrm{H}-2,87-92 \mathrm{~cm}$ ); however, these sediments were not recovered in Hole U1336B and were likely missed by coring gaps or sampled for whole-round studies before cores were described. Pumice fragments, sometimes as large as $2.0 \mathrm{~cm}$ in diameter, occur in Unit I. Most are well rounded and light gray to gray (N7/ to N6/) in color. Throughout Unit I, physical properties, including magnetic susceptibility, $\mathrm{b}^{*}$ and $\mathrm{L}^{*}$ reflectance, and GRA bulk density, all show higher amplitude variability than underlying units. $\mathrm{CaCO}_{3}$ content is also more variable in Unit I relative to Unit II, ranging between 48 and $90 \mathrm{wt} \%$ (Fig. F4). The transition to Unit II is indicated by an overall decrease in the amplitude of variation in the physical properties, a downhole increase 
in density and $\mathrm{L}^{*}$, a decrease in magnetic susceptibility, and a lesser abundance of the minor constituent radiolarians, clay, and foraminifers (Fig. F4).

\section{Unit II}

Intervals: 320-U1336A-8H-7, $5 \mathrm{~cm}$, through $22 \mathrm{X}-4$, $20 \mathrm{~cm}$; 320-U1336B-9H-5, $84 \mathrm{~cm}$, through $20 \mathrm{H}-$ $7,58 \mathrm{~cm}$ (end of Hole U1336B)

Depths: Hole U1336A = 73.05-189.50 m CSF; Hole $\mathrm{U} 1336 \mathrm{~B}=75.14-173.98 \mathrm{~m}$ CSF (end of hole)

Age: early Miocene to late Oligocene

Lithology: nannofossil ooze

The dominant lithology in Unit II is nannofossil ooze with vivid coloring. The uppermost $9.6 \mathrm{~m}$ of Unit II is pale yellow (2.5Y $8 / 2$ to $2.5 \mathrm{Y} 8 / 3$ ) nannofossil ooze that sharply overlies a sequence of alternating white $(2.5 \mathrm{Y} 8 / 1$ and $\mathrm{N} 8 /$ ) and light greenish gray (10GY 8/1) nannofossil ooze at $92.14 \mathrm{~m}$ CSF in Hole U1336A (Figs. F7, F8). Below 120 m CSF, light greenish gray (5G 8/1) millimeter-scale color bands are observed in centimeter-scale packets in nearly every core. Chert was encountered in the lower portion of this unit hampering coring recovery, but no layers were recovered directly. Numerous small angular fragments of chert were found in Section 320-U1336B-16H-CC and soupy intervals near tops of Cores 320-U1336B-17H through $19 \mathrm{H}$, representing fall-in sediment. A small fragment of in situ chert was recovered in interval 320-U1336B-18H-4, $106 \mathrm{~cm}$. Bioturbation is generally minor or nonvisible throughout the unit. $\mathrm{CaCO}_{3}$ content in Unit II is relatively constant, typically $>85 \mathrm{wt} \%$ (Fig. F4; see "Geochemistry"). Color reflectance parameter b* decreases abruptly at $92.14 \mathrm{~m}$ CSF in Hole U1336A and $91.85 \mathrm{~m}$ CSF in Hole U1336B and remains low throughout the unit. $L^{*}$ increases across the Unit I/II boundary, reaching a maximum near the top of Unit II ( 90) and gradually decreases with depth to $\sim 65-70$ at $\sim 180-190 \mathrm{~m}$ CSF (Fig. F7). Working downhole through Unit II, GRA bulk density increases from $~ 1.6$ to $1.9 \mathrm{~g} / \mathrm{cm}^{3}$. Magnetic susceptibility is very low (typically $<5 \times 10^{-5} \mathrm{SI}$ ), sometimes below zero, throughout the unit (Fig. F4; see "Physical properties").

\section{Unit III}

Intervals: 320-U1336A-22X-4, $20 \mathrm{~cm}$, through 35X-CC, $38 \mathrm{~cm}$

Depths: Hole U1336A = 189.5-299.6 m CSF

Age: Oligocene

Lithology: nannofossil chalk, and chert

The Unit II-III transition is identified by the transition to chalk. Dominant lithologies of Unit III are light greenish gray (10GY $8 / 1$ and $10 \mathrm{GY} 7 / 1)$ and white (7.5YR 8/1 and $\mathrm{N} \mathrm{8/)} \mathrm{nannofossil} \mathrm{chalk} \mathrm{with}$ light greenish gray (5G 8/1) millimeter-scale color banding and chert layers. In the upper $100 \mathrm{~m}$ of Unit III cherts are black (10YR 2/1) to dark greenish gray (10GY 4/1). Below 289 m CSF nannofossil chalk contains increasing amounts of micrite and cherts occur in different colors: olive yellow (2.5Y 6/6), dark brown (7.5Y 3/2), and pink (7.5YR 7/3) (see "Site U1336 thin sections" in "Core descriptions"). Thin section analyses show increasing abundance with depth of foraminifers in the cherts (see "Site U1336 thin sections" in "Core descriptions"). Foraminifer tests in the cherts have been filled with microcrystalline quartz or occasionally filled or replaced by opaques, likely pyrite (Fig. F9). GRA density continues to increase with depth, from $\sim 1.9 \mathrm{~g} / \mathrm{cm}^{3}$ at the top of the unit and reaching a maximum of $\sim 2.0-2.1 \mathrm{~g} / \mathrm{cm}^{3}$ from $282 \mathrm{~m} \mathrm{CSF}$ and below (Fig. F4; see "Physical properties"). Magnetic susceptibility in Unit III is generally low $\left(<5 \times 10^{-5} \mathrm{SI}\right)$ with thin instances of much higher values that correspond to the chert layers. $L^{*}$ is overall more variable and generally lower in Unit III, whereas $b^{*}$ shows more variability than overlying units. $\mathrm{CaCO}_{3}$ contents remain $>88 \mathrm{wt} \%$ in the chalk layers. Igneous rocks were not recovered at Site U1336.

\section{Discussion}

\section{Unit I light-dark color cycles}

Pronounced submeter-scale color variations are common within the nannofossil oozes of Miocene age found in Unit I. These light-dark cycles are associated with variations in the relative amounts of accessory lithologic components within the nannofossil oozes, including clay, radiolarians, and diatoms (Fig. F5). These lithologic cycles are also apparent in a higher amplitude of variation in physical properties, including $L^{*}, b^{*}$, magnetic susceptibility, and GRA bulk density (Fig. F4; see "Physical properties"). Nannofossils dominate these sediments, making up between $50 \%$ and $95 \%$ of smear slide samples. The remainder is made up of clay, radiolarians, or diatoms (Fig. F5; see "Site U1336 smear slides" in "Core descriptions"). Two white (10YR 8/1) diatom nannofossil ooze layers (Samples 320-U1336A-5H-2, 22$36 \mathrm{~cm}$, and $6 \mathrm{H}-2,87-92 \mathrm{~cm}$ ) occur at 38.34 and $48.40 \mathrm{~m}$ CSF. These layers stand out because they are visually brighter than the surrounding sediments (nearest $\mathrm{L}^{*}$ measurements are 88 and 83.5 for the upper and lower layers, respectively) and also have a unique spongy texture that causes pilling during surface scraping in preparation for line scan imaging. Smear slide analysis indicates that the diatom assemblage is composed primarily of pennate taxa, with abundant needlelike Thalassiothrix spp. (Fig. F6). The low abundance of diatoms $(<5 \%)$ in most dark layers, 
where abundance of radiolarians increases relative to nannofossils, suggests that the observed lithologic variations within the nannofossil oozes could be the product of dissolution cycles; however, more detailed mass accumulation rate data are needed to test this.

\section{Redox-related color changes}

Site U1336 sediments are marked by vivid color changes that are made obvious against the backdrop of otherwise relatively white nannofossil oozes and chalks. Sediment color shows a downhole shift from white (10YR 8/1) to very pale brown (10YR 7/3) through pale yellow $(2.5 \mathrm{Y} 8 / 2)$ to light greenish gray (10GY 8/1) over a $30 \mathrm{~m}$ thick interval (65-95 m CSF). This greenish gray color starts abruptly (Fig. F8) at 92.14 $\mathrm{m}$ CSF in Hole U1336A and at $91.8 \mathrm{~m}$ CSF in Hole U1336B and spans a $\sim 198 \mathrm{~m}$ thick interval before shifting to white and pink below $290.41 \mathrm{~m} \mathrm{CSF}$ in Hole U1336A (not recovered in Hole U1336B). Reflectance parameters $a^{*}$ and $b^{*}$, which measure green-red and blue-yellow portions of the spectrum, respectively, shift in a steplike manner to lower values with these observed color changes (Fig. F7). Magnetic susceptibility drops to near zero in the transition from very pale brown to pale yellow and remains very weak throughout the light greenish gray interval, the same pattern observed at Sites U1334 and U1335. With elevated Fe and Mn pore water concentrations, discrete millimeter- to centimeterscale color bands occur within the interval of light greenish gray to white nannofossil ooze where Fe reduction has occurred in Units II and III. Although there is no obvious lithologic specificity, the banded sediments are sometimes more consolidated than the immediately overlying and underlying sediments.

The pattern of changing sediment color, physical and magnetic properties, and pore water chemistry seen at Site U1336 suggests loss of Fe-bearing minerals during diagenesis by microbial Fe reduction. A diagenetic origin for the color bands is suggested by their occurrence in the interval of the sequence that has undergone Fe reduction, their lack of lithologic specificity, and induration sometimes associated with discrete beds with particularly prominent banding. Similar "light gray-green banded chalk" is reported from DSDP Site $79\left(2^{\circ} 33.02^{\prime} \mathrm{N}, 121^{\circ} 34.00^{\prime} \mathrm{W}\right)$ with high $\mathrm{Fe}(105 \mu \mathrm{M} / \mathrm{kg})$ and $\mathrm{Mn}(1000 \mu \mathrm{M} / \mathrm{kg})$ interstitial water concentrations (Presley and Kaplan, 1972).

\section{Summary}

At Site U1336 300 m of pelagic sediments are divided into three major lithologic units. Sediments are composed mainly of nannofossil oozes, nannofossil chalks, and chert. The early to middle Miocene sedimentary sequence of Unit I contains more radiolarians, clay, foraminifers, and diatoms relative to the early Miocene to early Oligocene sediments below $\sim 75 \mathrm{~m}$ CSF. Subtle changes in the relative proportions of these minor components produce meter-scale dark-light color cycles and two diatom-rich layers. Numerous rounded fragments of pumice occur throughout this unit. The oxidation-reduction reactions responsible for the observed vivid colors and pore water chemistry changes are likely fueled by enhanced availability of organic carbon relative to overlying and underlying sediments. Thin chert layers were encountered near $124 \mathrm{~m} \mathrm{CSF}$ in Unit II, but mainly broken fragments were recovered, except for a small in situ chert fragment at $159.6 \mathrm{~m}$ CSF in interval 320-U1336B-18H-4, $106 \mathrm{~cm}$. More abundant chert layers are common in Unit III.

\section{Biostratigraphy}

At Site U1336 we recovered a $300 \mathrm{~m}$ thick sequence of middle Miocene to lower Oligocene nannofossil ooze and chalk with thin chert layers toward the base. Calcareous nannofossils are present throughout the succession, and there appears to be a complete sequence of nannofossil zones from Zone NN6 (middle Miocene) through Zone NP22 (lower Oligocene), except for Zone NN3, which could not be resolved. Radiolarians are present in the upper half of the section only, and Zones RN6-RP22 are present. Similarly, diatoms are only found in the upper cores and are poorly preserved. Planktonic foraminifers are present throughout the succession, and Zones N12 (Subzone M9b)-O1 are recognized. Planktonic foraminifers are abundant and moderately well preserved in the Miocene but less well preserved in the Oligocene. No preservational changes were associated with the sediment color shift from brown and very pale brown to light greenish gray. Ostracodes were occasionally observed in samples. The nannofossil, foraminifer, radiolarian, and diatom datums and zonal determinations agree well, and an integrated calcareous and siliceous microfossil biozonation is shown in Figure F10. An age-depth plot including biostratigraphic and paleomagnetic datums is shown in Figure F11. Benthic foraminifers are present throughout the section and indicate lower bathyal to abyssal paleodepths.

\section{Calcareous nannofossils}

Calcareous nannofossil biostratigraphy is based on analysis of core catcher and core section samples from both holes. Depth positions (CSF) and age estimates of biostratigraphic marker events are presented in Table T3. Nannofossils are abundant and 
moderately well preserved in the Miocene with intervals of poor preservation. Preservation is poor to moderate through most of the Oligocene.

The uppermost sample investigated (Sample 320U1336A-1H-1, $110 \mathrm{~cm}$ ) contains Coronocyclus nitescens and Calcidiscus premacintyrei without Sphenolithus heteromorphus, indicating a Zone NN6 age. Sample 320-U1336B-1H-CC lacks C. nitescens and C. premacintyrei. The top common occurrence of Cyclicargolithus floridanus (lowermost Zone NN6) is recognized in Sample 320-U1336A-2H-6, $80 \mathrm{~cm}$, just above the top S. hetermorphus (base of Zone NN6) in Sample 320-U1336A-3H-2, $90 \mathrm{~cm}$. In Hole U1336B, both events occur within Core 320-U1336B-3H. Nannofossil Zones NN4 and NN5 cannot be differentiated in this succession because of the absence of the zonal marker Helicosphaera ampliaperta; however, the presence of Discoaster petaliformis between Samples 320U1336A-3H-4, $90 \mathrm{~cm}$, and 5H-4, $64 \mathrm{~cm}$, indicates a position in upper Zones NN4 to NN5 (Young, 1999; Raffi et al., 2006). The base of $D$. petaliformis has been calibrated at $15.70 \mathrm{Ma}$ at ODP Sites 925 and 926 (as Discoaster signus in Raffi et al., 2006). This event was observed in Sample 320-U1336A-5H-4, $64 \mathrm{~cm}$. The intra-Zone NN4 datum top common Discoaster deflandrei occurs in Sample 320-U1336A-4H-4, $90 \mathrm{~cm}$, at a level that appears to be too high in comparison with surrounding biostratigraphic datums. This may be due to difficulties in distinguishing $D$. deflandrei from Discoaster exilis in material where discoaster identification is impaired by relatively poor preservation. In Hole U1336B, the top common datum of $D$. deflandrei is quite distinct because of the lower sample resolution used; it occurs within Core 320-U1336B-5H.

The base of $S$. heteromorphus occurs in Sample 320U1336A-7H-2, $50 \mathrm{~cm}$, together with frequent Sphenolithus belemnos in Hole U1336A, and in Core $320-\mathrm{U} 1336 \mathrm{~B}-7 \mathrm{H}$. Zone NN3 is defined by the extinctions of $S$. belemnos (top) and Triquetrorhabdulus carinatus (bottom). As these events are only $1.5 \mathrm{~m}$ apart (i.e., in adjacent samples), this suggests that Zone NN3 is missing or confined to a condensed interval between Samples 320-U1336A-7H-2, $50 \mathrm{~cm}$, and 7H-3, $53 \mathrm{~cm}$. Alternatively, the ranges of one or both of these taxa may be modified in the equatorial Pacific Ocean.

The intra-Zone NN2 datums, base of $S$. belemnos and top acme of T. carinatus (Raffi et al., 2006) are recognized in Samples 320-U1336A-8H-CC and 13H-CC, respectively. The lowermost occurrence of Discoaster druggii was observed in Samples 320-U1336A-14H$\mathrm{CC}$ and 320-U1336B-14H-CC. Its rare and discontinuous distribution makes it difficult to exactly place the Zone NN1/NN2 boundary. The base of Sphenoli- thus disbelemnos occurs in Sample 320-U1336A-15HCC and Sample 320-U1336B-15H-1, $10 \mathrm{~cm}$. The top and base of $S$. delphix occurs in Samples 320-U1336A$17 \mathrm{H}-4,90 \mathrm{~cm}$, and $17 \mathrm{H}-6,90 \mathrm{~cm}$, respectively, although the species is rare and difficult to distinguish in these relatively poorly preserved assemblages. In Hole U1336B, S. delphix occurs from Sample 320U1336B 17H-1, $150 \mathrm{~cm}$, to $17 \mathrm{H}-3,149 \mathrm{~cm}$. The extinction of this species occurs just prior to ( $<100$ k.y.) the Oligocene/Miocene boundary.

The Oligocene succession is predominantly nannofossil chalk with abundant nannofossils but poor to moderate preservation. The top of Zone NP25 is recognized by the top of Sphenolithus ciperoensis in Sample 320-U1336A-20H-CC. The intra-Zone NP24 abundance crossover from Triquetrorhabdulus longus to T. carinatus is difficult to place because of the poor preservation of these nannolith taxa-especially calcitic overgrowth of the slender rodlike taxa T. longus, which makes it indistinct from the thicker T. carinatusbut our initial analysis places it between Samples 320-U1336A-20H-CC and 20H-5, $100 \mathrm{~cm}$, close to the top of $S$. ciperoensis datum. As at Sites U1332-U1335, the top of Cyclicargolithus abisectus was picked at this site in Sample 320-U1336A-19H-6, $70 \mathrm{~cm}$, at a level consistent with the calibration for the top acme of $C$. abisectus (also Sites U1332-U1335). In Hole U1336B, this species was only observed in the lowermost core catcher sample (320-U1336B-20H-CC). The top of this species thus appears to have biostratigraphic potential in the paleoequatorial Pacific Ocean. The base of Zone NP25 is placed at the top of Sphenolithus distentus in Sample 320-U1336A-24X-3, $73 \mathrm{~cm}$, and the base of Zone NP24 at the base of $S$. ciperoensis in Sample 320-U1336A-24X-5, $53 \mathrm{~cm}$. The first appearance of $S$. distentus occurs within Zone NP23, in Sample 320-U1336A-29X-3, $40 \mathrm{~cm}$. The top of Reticulofenestra umbilicus occurs in Sample 320-U1336A-35X-1, $34 \mathrm{~cm}$, at the base of the sedimentary succession marking the base of Zone NP23.

\section{Radiolarians}

Radiolarian stratigraphy at Site U1336 (Table T4) spans the interval from just above the Zone RN6/ RN5 boundary (middle Miocene) to the upper part of Zone RP22 (upper Oligocene). Below this level the sediments are barren of radiolarians. Above this level assemblages tend to have good to moderate preservation, with intermittent intervals of good preservation in Zones RN3 and RN4 (lower to middle Miocene). Species abundance and preservation are shown in Tables T5 and T6. One of the unusual aspects of this site was the recovery of well-preserved upper middle Miocene sediments practically at the seafloor. There is no sign of younger sedimentary material and only 
minor reworking of older microfossils into the sediments of Cores 320-U1336A-1H and $2 \mathrm{H}$. Most of the other sites drilled in the region a few degrees north of the Pacific Equator encounter a layer of barren clay or radiolarian clay of variable thickness at the sediment surface. This clay usually contains radiolarian microfossils of widely ranging ages. The sediment surface at Site U1336 appears swept clean.

The downsection decrease in preservation and ultimate disappearance of the radiolarians below Core 320-U1336A-19H appears to be associated with dissolution and reprecipitation of the biogenic silica as intergranular cement and chert. It has been proposed that the dissolution of biogenic silica is the source of silica forming porcellinite and chert, and on crust $<65 \mathrm{Ma}$ in age, almost all cherts in the Pacific lie $<150 \mathrm{~m}$ above basement (Moore, 2008b). Chert encountered at this site (see "Lithostratigraphy") fits within these criteria. What is unusual about silica dissolution at this site is that it extends so far up into the section. Normally the silica-free zone (the zone of the sediments at the base of a sedimentary section that is devoid of siliceous microfossils) extends only $\leq 40 \mathrm{~m}$ above the basement in Pacific sediments (Moore, 2008a). Here the silica-free zone extends $>120 \mathrm{~m}$ above basement, something that is usually seen only in sites on the older crust of the western Pacific. Moore (2008a, 2008b) proposes that the dissolution of the silica in basal sedimentary sections is associated with the circulation of warm hydrothermal waters in the upper oceanic crust that extends into the lower sediments when they are cut by permeable fractures and faults. Such small-offset faults appear to be present in the section near this site (Fig. F2). These faults, combined with possible higher heat flow so close to a major fracture zone (located $10 \mathrm{~km}$ south of the site), may have aided in a much more pervasive dissolution of the biogenic silica in the basal sediments at Site U1336.

The topmost part of the section corresponds to the lowest part of Zone RN6 (uppermost middle Miocene) that is based on the presence of Diarutus pettersoni and Dorcadospyris alata (Samples 320-U1366A-1H-4, 104-106 cm, and 320-U1336B-1H-CC). Only core catcher samples were investigated in Hole U1336B. Zone RN5 is well distinguished by four datum events (Table T4). The Zone RN5/RN4 boundary occurs between Samples 320-U1336A-4H-2, 105-107 cm, and $4 \mathrm{H}-4,105-107 \mathrm{~cm}$, and in Core $320-\mathrm{U} 1336 \mathrm{~B}-5 \mathrm{H}$. This boundary is defined by the evolutionary transition from Dorcadospyris dentata to D. alata.

In Hole U1336A, the Zone RN4/ RN3 boundary was recognized by the base of Calocycletta (Calocyclissima) costata between Samples 320-U1336A-6H-4, 105$107 \mathrm{~cm}$, and 6H-CC. The base of Zone RN3 is distin- guished by the evolutionary appearance of Stychocorys wolffii between Samples 320-U1336A-8H-2, 105$107 \mathrm{~cm}$, and $8 \mathrm{H}-4,105-107 \mathrm{~cm}$. The top of Zone RN1, defined by the top of Theocyrtis anossa, occurs between Samples 320-U1336A-12H-2, 105-107 cm, and $12 \mathrm{H}-4,105-107 \mathrm{~cm}$, and in Core $320-\mathrm{U} 1336 \mathrm{~B}-$ $14 \mathrm{H}$. The base of Zone RN1 is determined by the base of Cyrtocapsella tetrapera between Sample 320U1336A-15H-4, 105-107 cm, and Sample 320U1336A-15H-CC and in Core 320-U1336B-15H. The lower sections contain Lychnocanomma elongata, indicating Zone RP22. Eight radiolarian events are observed within Zone RP22 in Hole U1336A.

The Oligocene/Miocene boundary occurs between Sample 320-U1336A-16H-CC and Sample 320U1336A-17H-4, 105-107 cm, as suggested by the presence of Dorcadospyris cyclacantha, which has a short stratigraphic range across the Oligocene/ Miocene boundary. It appears at 23.29 Ma and disappears just after the Oligocene/Miocene boundary at 22.98 Ma. In Hole U1336B, D. cyclacantha was observed only in Sample U1336B-17H-CC.

\section{Diatoms}

The diatom stratigraphy in Hole U1336B (Table T7) spans the interval from just above the $C$. peplum zone (middle Miocene) in Core 320-U1336B-1H to the lowermost part of $C$. nicobarica zone (upper lower Miocene) in Sample 320-U1336B-7H-CC. Below Sample 320-U1336B-7H-CC, the sediments are barren of diatoms. Above this level the valves tend to be mostly poorly preserved. Sample 320-U1336B-1HCC contains the highest diversity with $C$. pulchellus as dominant component, accompanied by $C$. jouseana, and T. yabei. Fragments of the large centric diatoms Ethmodiscus are present in the upper part of Hole U1336B.

\section{Planktonic foraminifers}

A high-resolution planktonic foraminifer biostratigraphy was generated at Site U1336 using core catchers and supplementary additional samples, usually two per core. The sedimentary succession at this site ranges from Subzone M9b (Zone N12) (middle Miocene) to Zones O1-O2 (lower Oligocene) (Fig. F10; Table T8), which agrees well with calcareous nannofossil and radiolarian biostratigraphy (Fig. F11). Species abundance and preservation are shown in Tables T9 and T10. The preservation and abundance of planktonic foraminifers is moderate in the upper part of the succession and deteriorates to poor downcore with extensive infilling and encrustation. Preservation of planktonic foraminifer tests is inferior to nearby equatorial Pacific Ocean sites drilled during DSDP Leg 9 (Jenkins and Orr, 1972). Planktonic 
foraminifer tests can account for $>70 \%$ of the total residue in each sample, but some intervals are characterized by lower abundance and assemblages are dominated by dissolution-resistant forms (i.e., Samples 320-U1336A-6H-4, 38-40 cm, and 320-U1336B$17 \mathrm{H}-3,80-82 \mathrm{~cm}$ ); in such cases identification of datum events is difficult. As a result of the extensive infilling we applied a very broad definition to Globoquadrina venezuelana, which is dominant to abundant in most samples. Preservation is poor in the lowest part of the sedimentary succession consisting of nannofossil chalk. Planktonic foraminifers are encrusted with calcite in this section and it is difficult to identify and/or estimate the percentage of planktonic foraminifers in each sample because the washing process failed to successfully extract all the foraminifers from the chalk.

A continuous record of the middle to lower Miocene is observed from Subzone M9b (Zone N12) to Subzone M1a. Subzone M9a through Zone M8 (Zone N12) are distinguished on the basis of several datum events within the Globorotalia (Fohsella) fohsi group (Table T8). The base of Globorotalia (Fohsella) fohsi robusta occurred in Samples 320-U1336A-1H-3, 38$40 \mathrm{~cm}$, and 320-U1336B-1H-CC. The Zone M7/M8 (N11/N12) boundary is defined by the base of $G$. (Fohsella) fohsi sensu lato in Samples 320-U1336A$2 \mathrm{H}-\mathrm{CC}$ and 320-U1336B-2H-CC. The base of Zone N11 is indicated by the base of Globorotalia (Fohsella) "praefohsi" in Samples 320-U1336A-3H-5, 38-40 cm, and 320-U1336B-3H-CC.

It was not possible to fully constrain the boundary between Zones M6-M7 (N9-N10) because the base of Globorotalia (Fohsella) peripheroacuta (14.24 Ma) on which it is defined appears to occur deeper than the base of Orbulina spp. (14.74 Ma), which separates Zones M6 and M5. Higher resolution samples in Cores 320-U1336A-3H and $4 \mathrm{H}$ may be needed in order to fully resolve these zonal boundaries. However, Zone M5 is identified between the base of Orbulina spp. in Samples 320-U1336A-3H-CC and 320U1336B-3H-CC and the base of Praeorbulina sicana in Samples 320-U1336A-6H-2, 38-40 cm, and 320U1336B-6H-CC. The rarity of Catapsydrax dissimilis in Hole U1336A made it difficult to distinguish the Zone M3/M4 boundary; however, in Hole U1336B the top of $C$. dissimilis was constrained to the interval between Samples 320-U1336B-7H-CC and 8H-CC. It was not possible to identify the boundary between Zones M3 and M2 because of the absence of Globigerinatella insueta. The top of $P$. kugleri defines the top of Subzone M1b and was found between Samples 320U1336A-10H-CC and $11 \mathrm{H}-2,30-32 \mathrm{~cm}$. The base of Subzone M1b was between Samples 320-U1336A$15 \mathrm{H}-2,38-40 \mathrm{~cm}$, and $15 \mathrm{H}-4,38-40 \mathrm{~cm}$, using the base of Globoquadrina dehiscens. The co-occurrence of P. kugleri, Paragloborotalia pseudokugleri, and G. dehiscens in Sample 320-U1336A-11H-2, 38-40 cm, and Samples 320-U1336B-12-CC, 13-CC, and 14-CC indicate Subzone M1b.

The base of Zone M1 is marked by the base of $P$. $k u$ gleri and is employed to approximate the Oligocene/ Miocene boundary (Steininger et al., 1997). It occurs between Samples 320-U1336A-16H-CC and 17H-2, $38-40 \mathrm{~cm}$, and between Samples 320-U1336B-16H-1, $52-54 \mathrm{~cm}$, and $17 \mathrm{H}-3,80-82 \mathrm{~cm}$. Only specimens with a subacute periphery and more than six chambers in the final whorl were considered to be $P$. kugleri (see Pearson and Wade, 2009, for discussion). Sample 320-U1336B-16H-CC contained many reworked specimens of early and middle Oligocene age and could not be used to provide further constraint on the base of Zone M1.

In the upper part of Zone O6, robust dentoglobigerinids and paragloborotaliids are more abundant. The upper part of Zone $\mathrm{O} 6$ is indicated by the presence of $P$. pseudokugleri. The $150-250 \mu \mathrm{m}$ size fraction contains assemblages abundant and diverse in paragloborotaliids, but they are rare in the $>250 \mu \mathrm{m}$ size fraction. This is consistent with the size change in paragloborotaliids documented at Site 1218 (Wade et al., 2007). Frequent specimens of Dentoglobigerina galavisi, Dentoglobigerina tripartita, G. venezuelana, and Paragloborotalia nana are found in lowermost part of Zone O6. The top of Paragloborotalia opima marks the top of Zone O5, and whereas at previous sites it was not observed, the lower boundary of this zone is fully identified in Hole U1336A by the top of the common occurrence of Chiloguembelina cubensis $(28.0 \mathrm{Ma})$ that occurs between Samples 320-U1336A25X-2, 45-47 cm, and 25X-CC. The base of Globigerina angulisuturalis defines the base of Zone $\mathrm{O} 4$ and occurs between Samples 320-U1336A-27X-CC and $28 \mathrm{X}-2,20-22 \mathrm{~cm}$. Zone O3 is partially distinguished by the co-occurrence of Subbotina angiporoides, Turborotalia ampliapertura, and P. opima (i.e., Sample 320-U1336A-29X-CC). Zones O1 and O2 at the base of the succession are not fully constrained, although the lack of $P$. opima and the presence of $P$. nana, $C$. dissimilis, Dentoglobigerina spp., and Turborotalia ampliapertura indicate that the lower Oligocene is preserved. Further age control is difficult because of the poor preservation of the planktonic foraminifers in the deeper part of the section.

\section{Benthic foraminifers}

Benthic foraminifers were examined in core catcher samples from Holes U1336A and U1336B. The occurrence of benthic foraminifers at this site is shown in Tables T11 and T12. The sample intervals 
from Samples 320-U1336A-1H-CC through 35X-CC (8.22-299.61 m CSF) and 320-U1336B-1H-CC through 20H-CC (1.68-174.01 m CSF) contain benthic foraminifers continuously, although abundances are low overall. Samples 320-U1336A-34X-CC (294.10 m CSF), within a chert interval, and $6 \mathrm{H}-\mathrm{CC}(49.87 \mathrm{~m}$ $\mathrm{CSF}$ ), within a radiolarian ooze, contain rare benthic foraminifers. Benthic to planktonic foraminifer ratios are $\sim 1 \%-2 \%$ in Samples 320-U1336B-1H-CC through 16H-CC (8.22-136.86 $\mathrm{m} \mathrm{CSF})$, except in Sample 320-U1336B-6H-CC (49.87 m CSF), where the benthic to planktonic foraminifer ratio rises to $25 \%$. In Samples 320-U1336B-16H-CC through 20HCC (136.81-174.01 m CSF), benthic to planktonic foraminifer ratios increase to $5 \%-10 \%$. Fish teeth and ostracodes are present in most of the core catcher samples examined. Benthic foraminifer tests are moderately well preserved in the upper part of Site U1336 (Samples 320-U1336A-1H-CC through 19H-CC, 8.22-170.63 m CSF; and 320-U1336B-1HCC through 20H-CC, 1.68-174.01 m CSF), but preservation deteriorates and tests are frequently abraded and infilled below this level.

The Oligocene to middle Miocene benthic foraminifer assemblage at Site U1336 is relatively diverse and indicates oligotrophic, lower bathyal to abyssal paleodepths. Characteristic taxa are Cibicidoides mundulus, Globocassidulina subglobosa, Gyroidinoides spp., Laticarinina pauperata, Nuttallides umbonifer, Oridorsalis umbonatus, Pullenia bulloides, and Siphonodosaria spp. Brizalina pusilla is abundant (39\%) in Sample 320-U1336A-30X-CC (264.48 m CSF). The benthic foraminifer assemblage at Site U1336 closely resembles Oligocene and early Miocene assemblages previously described from the eastern equatorial Pacific Ocean (ODP Site 573, Thomas, 1985; ODP Sites 1218 and 1219, Takata and Nomura, 2005). The assemblage from Site U1336 also shows close affinity to Oligocene and middle Miocene assemblages from Sites U1332-U1334, although N. umbonifer occurs less frequently at Site U1336 than at these other sites.

\section{Paleomagnetism}

We conducted a paleomagnetic study of archive-half sections of 21 APC cores from Hole U1336A and 20 APC cores from Hole U1336B with the primary objective of determining the magnetostratigraphy of the site and providing chronostratigraphic constraints. To accomplish this, we measured the NRM of each section at either 5 or $2.5 \mathrm{~cm}$ intervals (depending on time availability) before and after demagnetization at a peak AF of $20 \mathrm{mT}$. AF demagnetization at a peak field of $10 \mathrm{mT}$ was also carried out for most Hole U1336B core sections. We processed the paleomag- netic data by removing measurements made within $5 \mathrm{~cm}$ (or $7.5 \mathrm{~cm}$ when measured at $2.5 \mathrm{~cm}$ intervals) of section ends and data from disturbed intervals (Table T13).

The FlexIt core orientation tool was not deployed at the site because the conclusion, derived from Sites U1331 and U1332, that the output of the tool was erratic and inconsistent with expected remanence directions for sediments of this age from this location (we expected Neogene declinations to lie close to north for the normal polarity and close to south for the reversed polarity). The remanence inclination is close to zero, as expected for a site located close to the paleoequator, making inclination not diagnostic of polarity. The lack of core orientation gave us an unwelcome degree of freedom in the assignment of polarity, as each core can be rotated in azimuth through $180^{\circ}$ to change the sign of any polarity zone. Azimuthal core orientation had to be determined solely by correlating distinct reversals patterns as recorded by the paleomagnetic declination with the GPTS (see "Paleomagnetism" in the "Methods" chapter and "Paleomagnetism" in the "Site U1331" chapter). Although this process is aided by biostratigraphic age constraints, which limit the range of possible correlations with the GPTS (see "Biostratigraphy"), it is the polarity zone pattern and its fit to the GPTS that provided the basis for the match. Once we had identified a possible reversal pattern, data were oriented so that normal and reversed polarity zones had declinations of $\sim 0^{\circ}$ and $\sim 180^{\circ}$, respectively.

We measured magnetic susceptibilities and masses of 138 discrete samples. Volumes of samples were recalculated using sediment MAD data (see "Physical properties") and the magnetic susceptibilities were subsequently normalized using recalculated volumes and masses. Of these samples, 20 were stepwise AF demagnetized and measured at $5 \mathrm{mT}$ steps to a peak field of $40 \mathrm{mT}$ and $10 \mathrm{mT}$ steps to $60 \mathrm{mT}$.

\section{Results}

Downhole paleomagnetic data for Holes U1336A and U1336B are presented in Figures F12, F13, F14, F15, and F16. Measurements of NRM above $\sim 80 \mathrm{~m}$ CSF in Holes U1336A and U1336B indicate moderate magnetization intensities $\left(\sim 1 \times 10^{-3} \mathrm{~A} / \mathrm{m}\right)$ with a patchy but generally weak VRM or isothermal remanent magnetization IRM drilling overprint (see "Paleomagnetism" in the "Site U1331" chapter). Polarity reversal sequences are clearly recognized in general. Demagnetization data from discrete samples above $\sim 80 \mathrm{~m}$ CSF (Fig. F17; Table T14) indicate that the characteristic remanent magnetization (ChRM) of the sediments is identified at the $10-20 \mathrm{mT}$ de- 
magnetization steps. Principal component analysis directions of the ChRM components above $\sim 80 \mathrm{~m}$ CSF agree with measurements of coeval intervals from the archive halves (Fig. F12), indicating that the magnetic directions after $20 \mathrm{mT}$ demagnetization provide a reliable indicator of the ChRM of the sediments.

Below $\sim 80 \mathrm{~m}$ CSF, a zone of diagenetic alteration involving dissolution of remanence carriers (see "Paleomagnetism" in the "Site U1334" chapter) reduces remanent intensities after $20 \mathrm{mT}$ AF demagnetization to values close to magnetometer noise level in the shipboard environment $\left(\sim 2 \times 10^{-5} \mathrm{~A} / \mathrm{m}\right)$. In this zone, sediment magnetizations have been partly or entirely overprinted during the coring process and remanent inclinations are sometimes steeply negative after AF demagnetization at a peak field of $20 \mathrm{mT}$. At 130-140 m CSF (Cores 320-U1336A-15H through $16 \mathrm{H}$ and $320-\mathrm{U} 1336 \mathrm{~B}-15 \mathrm{H}$ ) and below $\sim 160 \mathrm{~m}$ CSF (Cores 320-U1336A-19H through $21 \mathrm{H}$ and $320-\mathrm{U} 1336 \mathrm{~B}-18 \mathrm{H}$ through $20 \mathrm{H}$ ), polarity reversals are apparently present but the inclinations are steep (as much as $80^{\circ}$ ), indicating that the drilling overprint has not been effectively removed during shipboard demagnetization.

\section{Magnetostratigraphy}

In the upper $\sim 80 \mathrm{~m}$ CSF, correlation of polarity zones with the GPTS is guided by the biostratigraphic framework of key nannofossil and foraminifer datums from core catcher and additional samples (see "Biostratigraphy") but is based largely on the polarity zone pattern fit to the GPTS. Reversal depths are provided in Table T15 and polarity interpretation is shown in Figure F16. At the top of Holes U1336A and U1336B, polarity assignments are constrained by the tops of nannofossils $C$. nitescens and C. premacintyrei, which have ages of $12.12 \mathrm{Ma}$ and $12.45 \mathrm{Ma}$, respectively. We correlate the uppermost reversed polarity zone to the base of Chron C5r of the GPTS (Fig. F16). Cores 320-U1336A-3H and 320-U1336B$4 \mathrm{H}$ contain a $\sim 10 \mathrm{~m}$ thick normal polarity zone, which we tentatively correlate to normal polarity Chrons C5ACn and C5ADn; Chron C5ACr was not identified. The base of Core 320-U1336A-4H has an age of $15.7 \mathrm{Ma}$ (see "Biostratigraphy"); therefore, we correlate the reversal sequence within Cores 320U1336A-4H, 320-U1336B-4H, and 5H with Chrons C5ADr and C5Bn (Fig. F16). The top of the polarity zone corresponding to Chron $\mathrm{C} 5 \mathrm{Br}$ occurs at the base of Core 320-U1336-4H and top of Core 320$\mathrm{U} 1336 \mathrm{~B}-5 \mathrm{H}$, with the base of the polarity zone at the base of Core 320-U1336A-5H and at the top of Core $320-\mathrm{U} 1336 \mathrm{~B}-6 \mathrm{H}$. Below the polarity zone corresponding to Chron $\mathrm{C} 5 \mathrm{Br}$, our correlation with the
GPTS is relatively unambiguous through Core 320U1336A-9H, which contains the upper portions of Chron C6n. Below $~ 90$ m CCSF-A the magnetization intensity of the sediments decreases below analytical noise level; however, below $\sim 160 \mathrm{~m}$ CSF a reversal pattern is discernible (Figs. F13, F15) but difficult to correlate with GPTS in the absence of core orientation data.

\section{Geochemistry}

\section{Sediment gases sampling and analysis}

Headspace gas samples were taken at a frequency of one sample per core in Hole U1336A as part of the routine environmental protection and safety monitoring program. All headspace sample analyses resulted in nondetectable levels of methane $\left(\mathrm{C}_{1}\right.$; $<2$ ppmv), with no higher hydrocarbons.

\section{Interstitial water sampling and chemistry}

Twenty-two interstitial water samples were collected from Hole U1336B (Table T16) in the APC-cored interval using the whole-round squeezing method. Chemical constituents were determined according to the procedures outlined in "Geochemistry" in the "Methods" chapter. Chlorinity varies from $~ 555 \mathrm{mM}$ in the shallowest sample to $\sim 565-570 \mathrm{mM}$ in deeper samples (Fig. F18). Chlorinity values have a distinct increase from $\sim 555$ to $\sim 570 \mathrm{mM}$ in the uppermost $40 \mathrm{~m} \mathrm{CSF}$, potentially reflecting the change from the more saline ocean at the Last Glacial Maximum to the present (Adkins and Schrag, 2003). Alkalinity is relatively constant at $>2.5 \mathrm{mM}$ in the upper $110 \mathrm{~m}$ CSF, with a pronounced decline to $1 \mathrm{mM}$ by $170 \mathrm{~m}$ CSF. Sulfate concentrations decrease with depth to values of $22 \mathrm{mM}$. Dissolved phosphate concentrations are $\sim 5 \mu \mathrm{M}$ at $\sim 9 \mathrm{~m} \mathrm{CSF}$, decreasing to $\sim 1 \mu \mathrm{M}$ by $\sim 15 \mathrm{~m}$ CSF. Dissolved manganese has a broad peak to $>5 \mu \mathrm{M}$ from $\sim 25$ to $120 \mathrm{~m}$ CSF and then returns to $\sim 1.8 \mu \mathrm{M}$ in the deepest four samples. Below $100 \mathrm{~m}$ $\mathrm{CSF}$, dissolved iron increases coincident with manganese decline, with concentrations reaching $>10 \mu \mathrm{M}$ below $130 \mathrm{~m}$ CSF.

Because of the relatively high sulfate concentrations, dissolved $\mathrm{Ba}$ concentrations are below detection $(0.5 \mu \mathrm{M})$. Concentrations of dissolved silicate increase with depth from $<400$ to $800 \mu \mathrm{M}$.

Calcium and magnesium concentrations increase and decrease with depth, respectively, with calcium values from 10 to $29 \mathrm{mM}$ and magnesium values from 50 to $28 \mathrm{mM}$ (Fig. F18). This is indicative of diffusional control of $\mathrm{Mg}$ and $\mathrm{Ca}$ profiles between seawater at the top and the reaction zone of fluid and basalt in the underlying basement (e.g., Gieskes, 1981). 
Lithium concentrations decrease from $\sim 26 \mu \mathrm{M}$ at the surface to $<10 \mu \mathrm{M}$ below $130 \mathrm{~m} \mathrm{CSF}$, and potassium concentrations decrease with depth to values as low as $8 \mathrm{mM}$. Strontium concentrations increase from near-seawater values in the shallowest sample to $>400 \mu \mathrm{M}$ in the deepest samples, the highest values seen during this expedition. Boron concentrations range between 440 and $490 \mu \mathrm{M}$, showing a slight decrease downcore.

\section{Bulk sediment geochemistry}

Calcium carbonate $\left(\mathrm{CaCO}_{3}\right)$ and inorganic carbon concentrations were determined on sediment samples from Hole U1336A (Table T17; Fig. F19), and calcium carbonate, inorganic carbon, and total organic carbon (TOC) concentrations were determined on 39 sediment samples from Hole U1336B. TOC was not run on samples from Hole U1336A because samples from Hole U1336A were accidently sent to the Gulf Coast Repository during the Expedition 320/321 port call (Table T17; Fig. F19). Calcium carbonate concentrations ranged between 48 and 96 $\mathrm{wt} \%$. In the uppermost $\sim 90 \mathrm{~m} \mathrm{CSF}, \mathrm{CaCO}_{3}$ concentrations vary between 48 and $95 \mathrm{wt} \%$, with a distinct low at $48 \mathrm{~m}$ CSF. Below $90 \mathrm{~m} \mathrm{CSF}, \mathrm{CaCO}_{3}$ concentrations are consistently high (77 to $96 \mathrm{wt} \%$ ). Variations in $\mathrm{CaCO}_{3}$ concentrations correspond to lithostratigraphic observations (see "Lithostratigraphy"). TOC content is generally low throughout the sediment column, ranging between 0.05 and $0.08 \mathrm{wt} \%$; however, relatively high TOC concentrations $(0.10$ to $0.30 \mathrm{wt} \%$ ) are observed at 0.71 and $51.52 \mathrm{~m} \mathrm{CSF}$ and in the interval between 108.51 and $135.22 \mathrm{~m} \mathrm{CSF}$.

In Hole U1336B, bulk sediment samples were analyzed at a frequency of one per core for silicon, aluminum, iron, manganese, magnesium, calcium, sodium, potassium, titanium, phosphorus, barium, copper, chromium, scandium, strontium, vanadium, yttrium, and zirconium (Table T18). Concentrations of noncarbonate components like $\mathrm{SiO}_{2}, \mathrm{Al}_{2} \mathrm{O}_{3}$, and $\mathrm{Fe}_{2} \mathrm{O}_{3}$ display similar patterns, with the highest values occurring in the uppermost sediments and decreasing to a minimum between 100 and $140 \mathrm{~m} \mathrm{CSF}$ before a small peak at the base of the section. Ca (carbonate) content displays the opposite pattern, indicating the important role of carbonate dilution in determining the bulk sediment composition at this site.

\section{Physical properties}

Physical properties at Site U1336 were measured on whole cores, split cores, and discrete samples. WRMSL measurements (GRA bulk density, magnetic susceptibility, and $P$-wave velocity), thermal conductivity, and NGR measurements comprised the whole- core measurements. For Hole U1336A, compressional wave velocity measurements on split cores and MAD analyses on discrete core samples were made at a frequency of one per undisturbed section in Cores 320U1336A-1H through 35X. The SHMSL, configured with the Ocean Optics sensor, was used to measure spectral reflectance on archive-half sections. Resolution was reduced from 2.5 to $5 \mathrm{~cm}$ for Hole U1336A cores as a result of time constraints.

Hole U1336B cores were analyzed by the WRMSL and NGR detector during Expedition 320 and placed directly into cold storage unsplit. During Expedition 321 , thermal conductivity measurements were made on whole-round sections. After the cores were split, MAD and velocity measurements were made on samples from every other section. Sediment reflectance was measured on all archive-half cores with the SHMSL at a resolution of $2.5 \mathrm{~cm}$.

\section{Density and porosity}

Two methods were used to determine bulk sediment properties at Site U1336, GRA for the bulk density of whole-round sections (Fig. F20), and MAD analyses for wet bulk density, dry bulk density, grain density, water content, and porosity of discrete samples (Fig. F21; Table T19). MAD and GRA bulk density measurements display the same trends and are similar in absolute values through the entire section (Fig. F21B). Cross-plots of wet bulk density and dry bulk density versus interpolated GRA bulk density (Fig. F22) show excellent correlation between MAD and GRA density data.

Generally, wet bulk density corresponds with changes in lithology (Fig. F21B). Wet bulk density is lowest in lithologic Unit I $\left(1.4-1.7 \mathrm{~g} / \mathrm{cm}^{3}\right)$ and reflects variations in the amount of minor lithologic components (clay, radiolarians, and diatoms) within the major lithology of nannofossil ooze. In Unit II, bulk density increases slightly and becomes more uniform $\left(\sim 1.7 \mathrm{~g} / \mathrm{cm}^{3}\right)$. In Unit III, which also corresponds to the XCB-cored interval, bulk density becomes highly irregular, ranging from lower density at the top of cores to higher density at the base of cores. This pattern reflects drilling disturbance at the top of XCB cores. The average wet bulk density for the $\mathrm{XCB}$ portion can be determined from the discrete MAD analyses that were cut directly from undisturbed intervals. Wet bulk density values in Unit III average $1.9 \mathrm{~g} / \mathrm{cm}^{3}$, reflecting increased compaction of the sediments at depths $>180 \mathrm{~m}$ CSF.

Variations in grain density $\left(\rho_{s}\right)$ in Hole U1336A generally match changes in lithology (Fig. F21C). At the top of Hole U1336A grain density is $3.0 \mathrm{~g} / \mathrm{cm}^{3}$ and decreases rapidly, reflecting clay-rich sediments that grade rapidly into nannofossil ooze. Grain density 
averages $2.7 \mathrm{~g} / \mathrm{cm}^{3}$ for most of the section, varying from 2.6 to $2.9 \mathrm{~g} / \mathrm{cm}^{3}$. This average and range reflect the dominance of carbonate material (calcite; $\rho_{\mathrm{s}}=$ $2.70 \mathrm{~g} / \mathrm{cm}^{3}$ ) at Site U1336. Grain densities determined for Hole U1336B average $\sim 0.1 \mathrm{~g} / \mathrm{cm}^{3}$ less than grain densities determined for the same interval in Hole U1336A. The lower density of Hole U1336B material most likely reflects a larger sample volume and reduction of measurement error and error associated with mass and volume values derived from the assumed salt content of the pore fluid.

Porosity and water content vary inversely with wet bulk density (Fig. F21A). The highest porosities occur in lithologic Unit I, varying from $65 \%$ to $80 \%$. At the boundary between Units I and II porosity begins to decrease gradually toward the base of Unit II, where values average from $55 \%$ to $60 \%$ at $\sim 184 \mathrm{~m}$ CSF. A shift to lower porosity accompanies the shift to higher density in Unit III. Porosity in this interval ranges from $45 \%$ to $60 \%$.

\section{Magnetic susceptibility}

Whole-round magnetic susceptibility measurements correlate well with the major differences in lithology at Site U1336 (Fig. F20). Magnetic susceptibility values are highest in lithologic Unit I and show high amplitude and high frequency variations from $5 \times 10^{-5}$ to $30 \times 10^{-5}$ SI. Across the boundary between Units I and II, susceptibility decreases from $\sim 10 \times 10^{-5}$ to near 0 SI and remains low to the bottom of Hole U1336A. There is a slight increase in the amplitude and frequency of the variation of magnetic susceptibility in Unit III.

\section{Compressional wave velocity}

\section{Shipboard results}

Velocity measurements made with the $P$-wave logger (PWL) on whole-round sections and discrete measurements from split cores follow similar trends of increasing velocity with increasing depth as a result of increased compaction (Fig. F23). Discrete velocity measurements along the $x$-axis (contact probe) follow the trend of the PWL results in Hole U1336A (Fig. F23; Table T20) but exceed the PWL velocities on average by $20 \mathrm{~m} / \mathrm{s}$. An offset of $40 \mathrm{~m} / \mathrm{s}$ is present in the first $25 \mathrm{~m}$ of the section in Hole U1336A. The cores in this interval appeared dry and fractured, which may account for the disparity. The $x$-axis velocities determined in Hole U1336B average $50 \mathrm{~m} / \mathrm{s}$ higher than those over the comparable interval in Hole U1336A. Differences in the pressure applied in making contact between the sediment and transducers may account for this difference. Velocity mea- surements in the $y$ - and $z$-axis directions (insertion probe) generally exceed the PWL velocity by $10 \mathrm{~m} / \mathrm{s}$. Differences between the whole-core and split-core measurements possibly reflect the presence of water in the space between the core liner and sediment in the whole cores, sediment fracturing as the $y$ - and $z$ axis transducers penetrate the split core, and slight compaction of the sediment in the contact probe technique. No $y$ - or $z$-axis velocity measurements were made below $150 \mathrm{~m} \mathrm{CSF}$, as the XCB-cored sediment was hard and fractured easily with insertion of the transducers.

Velocities are between 1480 and $1500 \mathrm{~m} / \mathrm{s}$ in lithologic Unit I and between 1480 and $1530 \mathrm{~m} / \mathrm{s}$ in Unit II. At $\sim 176 \mathrm{~m}$ CSF, velocities begin to increase rapidly into Unit III, from 1530 to $\sim 1960 \mathrm{~m} / \mathrm{s}$ at $208 \mathrm{~m} \mathrm{CSF}$. The remainder of Unit III shows high frequency and high amplitude variation, averaging $1910 \mathrm{~m} / \mathrm{s}$ in this lithified and highly biscuited interval.

\section{Postcruise correction}

The $x$-direction velocities for Hole U1336A were determined using a liner thickness of $3.2 \mathrm{~mm}$, the correction that was initially applied at Site U1334 (see "Physical properties" in the "Site U1334" chapter). This correction was not applied to velocities determined for Hole U1336B. These velocities were determined using a core liner thickness of $2.7 \mathrm{~mm}$ for the liner correction. During the analysis of Hole U1337A cores, it was determined that high $x$-direction velocities do not result from thicker than expected core liner but instead are the result of using an incorrect value for the system delay associated with the contact probe (see "Physical properties" in the "Site U1337" chapter). Critical parameters used in this correction are system delay $=19.811 \mu$ s, liner thickness $=2.7 \mathrm{~mm}$, and liner delay $=1.26 \mu \mathrm{s}$. During the analysis of Hole U1337A cores, it also was determined that consistently low PWL velocities required the addition of a constant value that would produce a reasonable velocity of water $(\sim 1495 \mathrm{~m} / \mathrm{s})$ for the quality assurance/quality control liner (see "Physical properties" in the "Site U1337" chapter). These corrections have not been applied to the velocity data presented in this chapter.

\section{Natural gamma radiation}

NGR was measured in both holes at Site U1336 (Fig. F20). The highest counts per second are present at the seafloor ( $\sim 56 \mathrm{cps})$. The NGR signal rapidly decreases with depth in lithologic Unit I, with small variations centered at $5 \mathrm{cps}$. At the boundary between Units I and II, NGR values decrease to $\sim 2$ cps. NGR is uniform at $\sim 2$ cps through Units II and III. 


\section{Thermal conductivity}

Thermal conductivity was measured on the third section of each core from Hole U1336A and the fourth section of each core from Hole U1336B (Table T21). Thermal conductivity increases slightly with depth at the site (Fig. F24) and is inversely related to porosity (Fig. F25). Lower conductivity occurs with higher porosity as increased interstitial spacing attenuates the applied current from the probe. Overall, thermal conductivity decreases from 1.2 to $1 \mathrm{~W} /(\mathrm{m} \cdot \mathrm{K})$ through lithologic Unit I, with a minimum conductivity of $0.91 \mathrm{~W} /(\mathrm{m} \cdot \mathrm{K})$ at $31 \mathrm{~m} \mathrm{CSF}$. Through Units II and III, thermal conductivity increases from 1 to $1.4 \mathrm{~W} /(\mathrm{m} \cdot \mathrm{K})$, whereas porosity decreases over a similarly gradual trend of $75 \%$ to $50 \%$ (Fig. F21A). Below $183 \mathrm{~m}$ CSF, thermal conductivity decreases in XCBcored sediment, possibly as a result of increased fractures and occurrence of sediment biscuits. Thermal conductivity values were not recorded deeper than $189 \mathrm{~m}$ CSF because the sediment was too hard to insert the probe.

\section{Reflectance spectroscopy}

Spectral reflectance was measured on the archivehalf sections from Holes U1336A and U1336B using the SHMSL (Fig. F26). Variations in luminance $\left(L^{*}\right)$ correspond to pronounced lithologic changes. In lithologic Unit I, L* values are lowest (50-80) and display high-amplitude variations, reflecting changes in minor lithologic components. Values in Unit II are higher and more uniform, reflecting the relatively pure nannofossil ooze of this unit. Luminance values are slightly lower and more variable in Unit III. Variations in $\mathrm{a}^{*}$ (blue-yellow) and $\mathrm{b}^{*}$ (greenred) also reflect changes in lithology, with higher and more variable values in Unit I compared to Unit II. Both $\mathrm{a}^{*}$ and $\mathrm{b}^{*}$ exhibit a steplike decrease at $92 \mathrm{~m}$ CSF that is associated with a sharp change in the color of the nannofossil ooze from pale yellow to greenish gray.

\section{Stratigraphic correlation and composite section}

STMSL data were collected at $5 \mathrm{~cm}$ intervals from Hole U1336B and compared to WRMSL data obtained at $2.5 \mathrm{~cm}$ resolution from Hole U1336A during Expedition 320. In this way, drilling was monitored in Hole U1336B in real time to maximize the opportunity for the recovery and construction of a stratigraphically complete composite section.
Cores from Hole U1336B were also measured on the WRMSL during Expedition 320 and left onboard as whole-round sections to be split and described during Expedition 321. After the cores were split and described a composite section was constructed.

Magnetic susceptibility and GRA density proved most useful for correlating between holes at Site U1336 (Figs. F27, F28). Features in the magnetic susceptibility and GRA density are well aligned between Holes U1336A and U1336B to $~ 94 \mathrm{~m}$ CCSF-A. The correlation between the two holes is presented in Figures F27 and F28. Offsets and composite depths are listed in Table T22. Below $\sim 94 \mathrm{~m}$ CCSF-A, the magnetic susceptibility signal drops to very low values but density data are good enough to sustain a correlation to interval 320-U1334B-14H-4, $122 \mathrm{~cm}$. At this point (138.50 m CCSF-A) sediments recovered in both holes are disturbed. Core 320-U1336B$15 \mathrm{H}$ was appended to the bottom of the splice (Table T23). Near the bottom of Core 320-U1336B-18H the splice shifts to Core 320-U1336A-18H and continues to the base of the hole by appending Hole U1336A cores (Table T23). A preferred splice would have been to append Core 321-U1336A-15H just above the disturbed section at the base of Core 321-U1336B$14 \mathrm{H}$. However, this was not allowed by Correlator software. The critical interval from Cores 320U1336B-14H through 320-U1336A-18H is illustrated in Figure F29.

A growth factor of 1.13 is calculated by linear regression for the top $94 \mathrm{~m}$ CCSF-A of Site U1336, indicating a 13\% increase in CCSF-A relative to CSF depth (Fig. F30). We used this value to calculate CCSF-B depth presented in Table T22 to aid in the calculation of sedimentation and mass accumulation rates.

\section{Sedimentation rates}

All principal biostratigraphic datums and a set of 33 tentatively interpreted paleomagnetic reversals (restricted to the APC-cored sections) (Table T24; see also "Biostratigraphy" and "Paleomagnetism") were used in establishing age control (Fig. F11). Paleomagnetic reversals were used to calculate the average LSRs for the upper $74 \mathrm{~m}$ CCSF-B of the section at Site U1336, as depicted in Figure F11. Below $74 \mathrm{~m}$ CCSF-B, only biostratigraphic datums were used to calculate the average LSRs.

The LSR at Site U1336 decreases from $15 \mathrm{~m} / \mathrm{m} . \mathrm{y}$. in the upper Oligocene to $12 \mathrm{~m} / \mathrm{m} . \mathrm{y}$. in the lower Miocene and stays relatively constant at $9 \mathrm{~m} / \mathrm{m}$.y. in the remainder of the section (Fig. F11). 


\section{References}

Adkins, J.F., and Schrag, D.P., 2003. Reconstructing Last Glacial Maximum bottom water salinities from deep-sea sediment pore fluid profiles. Earth Planet Sci. Lett., 216:109-123. doi:10.1016/S0012-821X(03)00502-8

Amante, C., and Eakins, B.W., 2008. ETOPO1 1 Arc-Minute Global Relief Model: Procedures, Data Sources and Analysis: Washington, DC (DOC/NOAA/NESDIS/NGDC).

Billups, K., Pälike, H., Channell, J.E.T., Zachos, J.C., and Shackleton, N.J., 2004. Astronomic calibration of the late Oligocene through early Miocene geomagnetic polarity time scale. Earth Planet. Sci. Lett., 224(1-2):3344. doi:10.1016/j.epsl.2004.05.004

Cande, S.C., LaBrecque, J.L., Larson, R.L., Pitmann, W.C., III, Golovchenko, X., and Haxby, W.F., 1989. Magnetic Lineations of the World's Ocean Basins. AAPG Map Ser., 13.

Engebretson, D.C., Cox, A., and Gordon, R.G., 1985. Relative Motions between Oceanic and Continental Plates in the Pacific Basin. Spec. Pap.-Geol. Soc. Am., 206.

Gieskes, J.M., 1981. Deep-sea drilling interstitial water studies: implications for chemical alteration of the oceanic crust, Layers I and II. In Warme, J.E., Douglas, R.G., and Winterer, E.L. (Eds.), The Deep Sea Drilling Project: $A$ Decade of Progress. Spec. Publ.-Soc. Econ. Paleontol. Mineral., 32:149-167.

Hays, J.D., et al., 1972. Init. Repts. DSDP, 9: Washington, DC (U.S. Govt. Printing Office). doi:10.2973/ dsdp.proc.9.1972

Holbourn, A., Kuhnt, W., Schulz, M., and Erlenkeuser, H., 2005. Impacts of orbital forcing and atmospheric $\mathrm{CO}_{2}$ on Miocene ice-sheet expansion. Nature (London, U.K.), 438(7067):483-487. doi:10.1038/nature04123

Jenkins, D.G., and Orr, W.N., 1972. Planktonic foraminiferal biostratigraphy of the eastern equatorial PacificDSDP Leg 9. In Hays, J.D., et al., Init. Repts. DSDP, 9: Washington, DC (U.S. Govt. Printing Office), 10591193. doi:10.2973/dsdp.proc.9.125.1972

Knappenberger, M., 2000. Sedimentation rates and Pacific plate motion calculated using seismic cross sections of the Neogene equatorial sediment bulge [M.Sc. thesis]. Boise State Univ., Idaho.

Koppers, A.A.P., Phipps Morgan, J., Morgan, J.W., and Staudigel, H., 2001. Testing the fixed hotspot hypothesis using ${ }^{40} \mathrm{Ar} /{ }^{39} \mathrm{Ar}$ age progressions along seamount trails. Earth Planet. Sci. Lett., 185(3-4):237-252. doi:10.1016/ S0012-821X(00)00387-3

Lyle, M., 2003. Neogene carbonate burial in the Pacific Ocean. Paleoceanography, 18(3):1059. doi:10.1029/ 2002PA000777

Lyle, M., Liberty, L., Moore, T.C., Jr., and Rea, D.K., 2002. Development of a seismic stratigraphy for the Paleogene sedimentary section, central tropical Pacific Ocean. In Lyle, M., Wilson, P.A., Janecek, T.R., et al., Proc. ODP, Init. Repts., 199: College Station, TX (Ocean Drilling Program), 1-21. doi:10.2973/ odp.proc.ir.199.104.2002
Lyle, M., Wilson, P.A., Janecek, T.R., et al., 2002. Proc. ODP, Init. Repts., 199: College Station, TX (Ocean Drilling Program). doi:10.2973/odp.proc.ir.199.2002

Lyle, M.W., Pälike, H., Moore, T.C., Mitchell, N., and Backman, J., 2006. Summary Report of R/V Roger Revelle Site Survey AMATO3 to the IODP Environmental Protection and Safety Panel (EPSP) in Support for Proposal IODP626: Southampton, U.K. (Univ. Southampton). http:// eprints.soton.ac.uk/45921/

Mayer, L.A., Shipley, T.H., Theyer, F., Wilkens, R.H., and Winterer, E.L., 1985. Seismic modeling and paleoceanography at Deep Sea Drilling Project Site 574. In Mayer, L., Theyer, F., Thomas, E., et al., Init. Repts. DSDP, 85: Washington, DC (U.S. Govt. Printing Office), 947-970. doi:10.2973/dsdp.proc.85.132.1985

Miller, K.G., Wright, J.D., and Fairbanks, R.G., 1991. Unlocking the ice house: Oligocene-Miocene oxygen isotopes, eustasy, and margin erosion. J. Geophys. Res., [Solid Earth], 96(B4):6829-6848. doi:10.1029/ 90JB02015

Moore, T.C., Jr., 2008a. Biogenic silica and chert in the Pacific Ocean. Geology, 36(12):975-978. doi:10.1130/ G25057A.1

Moore, T.C., Jr., 2008b. Chert in the Pacific: biogenic silica and hydrothermal circulation. Palaeogeogr., Palaeoclimatol., Palaeoecol., 261(1-2):87-99. doi:10.1016/ j.palaeo.2008.01.009

Müller, R.D., Roest, W.R., Royer, J.-Y., Gahagan, L.M., and Sclater, J.G., 1997. Digital isochrons of the world's ocean floor. J. Geophys. Res., [Solid Earth], 102(B2):32113214. doi:10.1029/96JB01781

Pälike, H., Frazier, J., and Zachos, J.C., 2006b. Extended orbitally forced palaeoclimatic records from the equatorial Atlantic Ceara Rise. Quat. Sci. Rev., 25(23-24):31383149. doi:10.1016/j.quascirev.2006.02.011

Pälike, H., Lyle, M.W., Ahagon, N., Raffi, I., Gamage, K., and Zarikian, C.A., 2008. Pacific equatorial age transect. IODP Sci. Prosp., 320/321. doi:10.2204/ iodp.sp.320321.2008

Pälike, H., Norris, R.D., Herrle, J.O., Wilson, P.A., Coxall, H.K., Lear, C.H., Shackleton, N.J., Tripati, A.K., and Wade, B.S., 2006a. The heartbeat of the Oligocene climate system. Science, 314(5807):1894-1898. doi:10.1126/science.1133822

Paul, H.A., Zachos, J.C., Flower, B.P., and Tripati, A., 2000. Orbitally induced climate and geochemical variability across the Oligocene/Miocene boundary. Paleoceanography, 15(5):471-485. doi:10.1029/1999PA000443

Pearson, P.N., and Wade, B.S., 2009. Taxonomy and stable isotope paleoecology of well-preserved planktonic foraminifera from the uppermost Oligocene of Trinidad. $J$. Foraminifer. Res., 39(3):191-217. doi:10.2113/ gsjfr.39.3.191

Petronotis, K.E., 1991. Paleomagnetic studies of the skewness of Pacific plate marine magnetic anomalies 2532R: implications for anomalous skewness and the motion of the Pacific plate and hotspots [Ph.D. thesis]. Northwestern Univ., Evanston, IL.

Petronotis, K.E., Gordon, R.G., and Acton, G.D., 1994. A $57 \mathrm{Ma}$ Pacific plate paleomagnetic pole determined 
from a skewness analysis of crossings of marine magnetic anomaly 25r. Geophys. J. Int., 118(3):529-554. doi:10.1111/j.1365-246X.1994.tb03983.x

Presley, B.J., and Kaplan, I.R., 1972. Interstitial water chemistry: Deep Sea Drilling Project, Leg 9. In Hayes, J.D., et al., Init. Repts. DSDP, 9: Washington, D.C. (U.S. Govt. Printing Office), 841-844. doi:10.2973/ dsdp.proc.9.116.1972

Raffi, I., Backman, J., Fornaciari, E., Pälike, H., Rio, D., Lourens, L., and Hilgen, F., 2006. A review of calcareous nannofossil astrobiochronology encompassing the past 25 million years. Quat. Sci. Rev., 25(23-24):3113-3137. doi:10.1016/j.quascirev.2006.07.007

Sager, W.W., and Pringle, M.S., 1988. Mid-Cretaceous to early Tertiary apparent polar wander path of the Pacific plate. J. Geophys. Res., [Solid Earth], 93(B10):1175311771. doi:10.1029/JB093iB10p11753

Shackleton, N.J., Hall, M.A., Raffi, I., Tauxe, L., and Zachos, J., 2000. Astronomical calibration age for the Oligocene-Miocene boundary. Geology, 28(5):447-450. doi:10.1130/00917613(2000)28<447:ACAFTO>2.0.CO;2

Steininger, F.F., Aubry, M.P., Berggren, W.A., Biolzi, M., Borsetti, A.M., Brzobohaty, R., Cartlidge, J.E., Cati, F., Corfield, R., Gelati, R., Iacarrino, S., Mödden, C., Napoleone, D., Nolf, F., Ottner, B., Reichenbacher, B., Rögl, F., Roetzel, R., Spezzaferri, S., Tateo, F., Villa, G., Wielandt, U., Zevenboom, D., and Zorn, I., 1997. The global stratotype sample and point the GSSP for the base of the Neogene (the Paleogene/Neogene boundary). Episodes, 20:23-28.

Takata, H., and Nomura, R., 2005. Data report: Oligocene benthic foraminifers from the eastern equatorial Pacific, Sites 1218 and 1219, ODP Leg 199. In Wilson, P.A., Lyle,
M., and Firth, J.V. (Eds.), Proc. ODP, Sci. Results,199: College Station, TX (Ocean Drilling Program), 1-26. doi:10.2973/odp.proc.sr.199.224.2005

Thomas, E., 1985. Late Eocene to Recent deep-sea benthic foraminifers from the central equatorial Pacific Ocean. In Mayer, L., Theyer, F., Thomas, E., et al., Init. Repts. DSDP, 85: Washington, DC (U.S. Govt. Printing Office), 655-694. doi:10.2973/dsdp.proc.85.117.1985

van Andel, T.H., 1975. Mesozoic/Cenozoic calcite compensation depth and the global distribution of calcareous sediments. Earth Planet. Sci. Lett., 26(2):187-194. doi:10.1016/0012-821X(75)90086-2

Wade, B.S., Berggren, W.A., and Olsson, R.K., 2007. The biostratigraphy and paleobiology of Oligocene planktonic foraminifera from the equatorial Pacific Ocean (ODP Site 1218). Mar. Micropaleontol., 62(3):167-179. doi:10.1016/j.marmicro.2006.08.005

Young, J.R., 1999. Neogene. In Bown, P.R. (Ed.), Calcareous Nannofossil Biostratigraphy: Dordrecht, The Netherlands (Kluwer Academic Publ.), 225-265.

Zachos, J., Pagani, M., Sloan, L., Thomas, E., and Billups, K., 2001a. Trends, rhythms, and aberrations in global climate 65 Ma to present. Science, 292(5517):686-693. doi:10.1126/science.1059412

Zachos, J.C., Flower, B.P., and Paul, H., 1997. Orbitally paced climate oscillations across the Oligocene/Miocene boundary. Nature (London, U. K.), 388(6642):567570. doi:10.1038/41528

Zachos, J.C., Shackleton, N.J., Revenaugh, J.S., Pälike, H., and Flower, B.P., 2001. Climate response to orbital forcing across the Oligocene-Miocene boundary. Science, 292(5515):274-278. doi:10.1126/science.1058288

Publication: 30 October 2010 MS 320321-108 
Figure F1. A. ETOPO1 (Amante and Eakins, 2008) bathymetric overview map of Site U1336 and PEAT drilling locations with previous ODP and DSDP sites. F.Z. = fracture zone. B. Swath bathymetry from AMAT-03 site survey, Site U1336 region. White line = survey Line 6 .
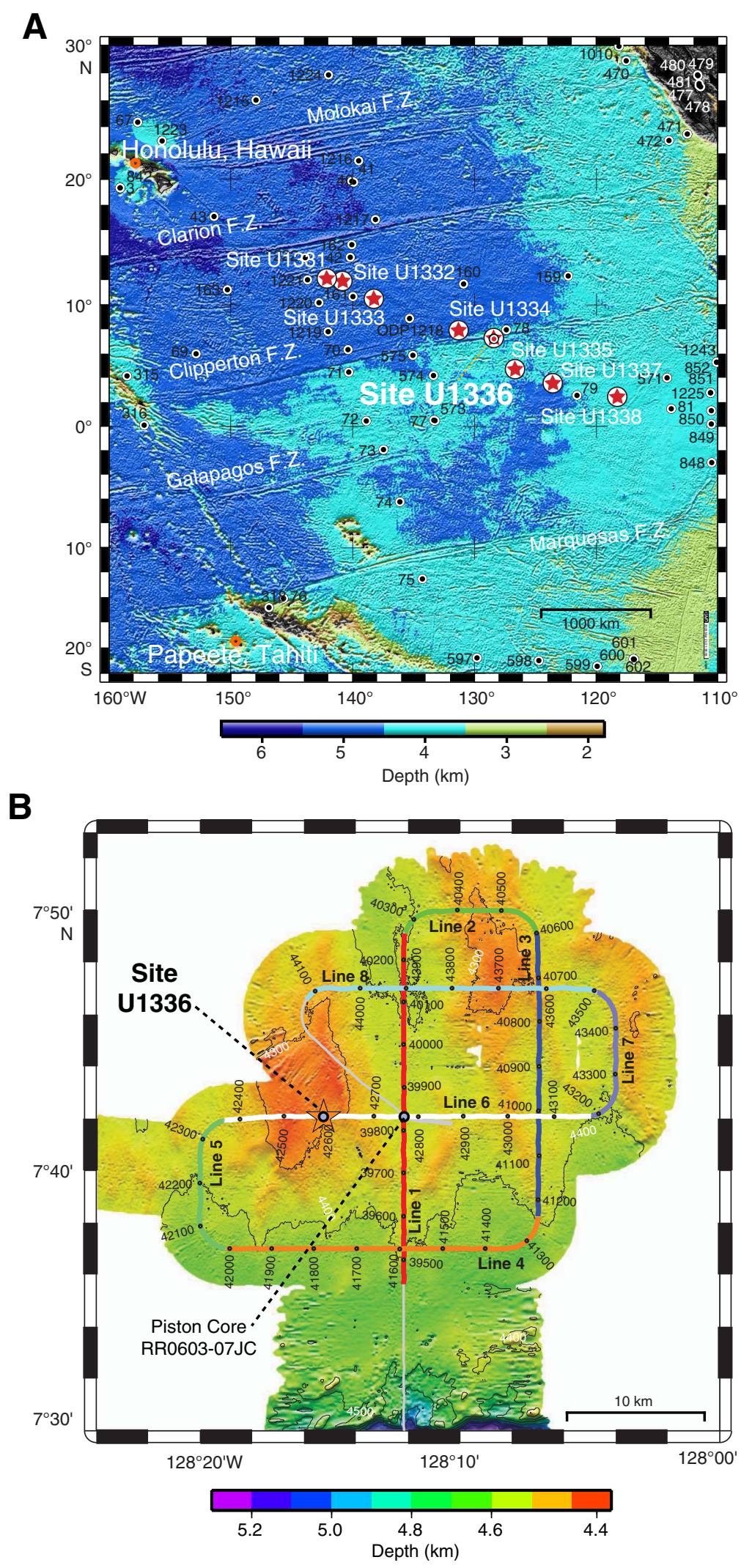
Figure F2. Seismic reflection profile Line 6 from 48-channel seismic reflection survey (Lyle et al., 2006). Data are filtered, stacked, and migrated. $\mathrm{SP}=$ shotpoint.

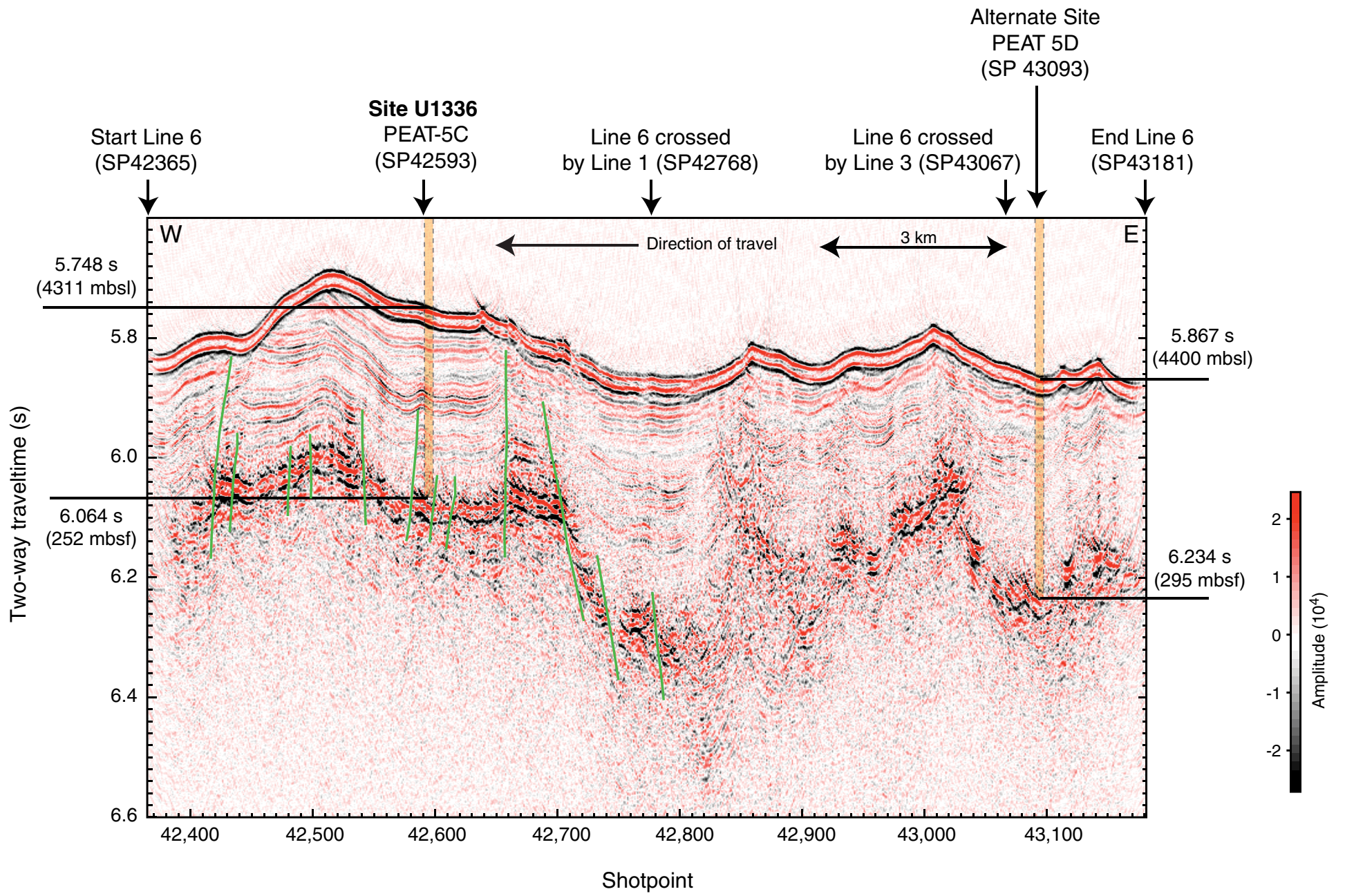


Figure F3. Site U1336 summary.

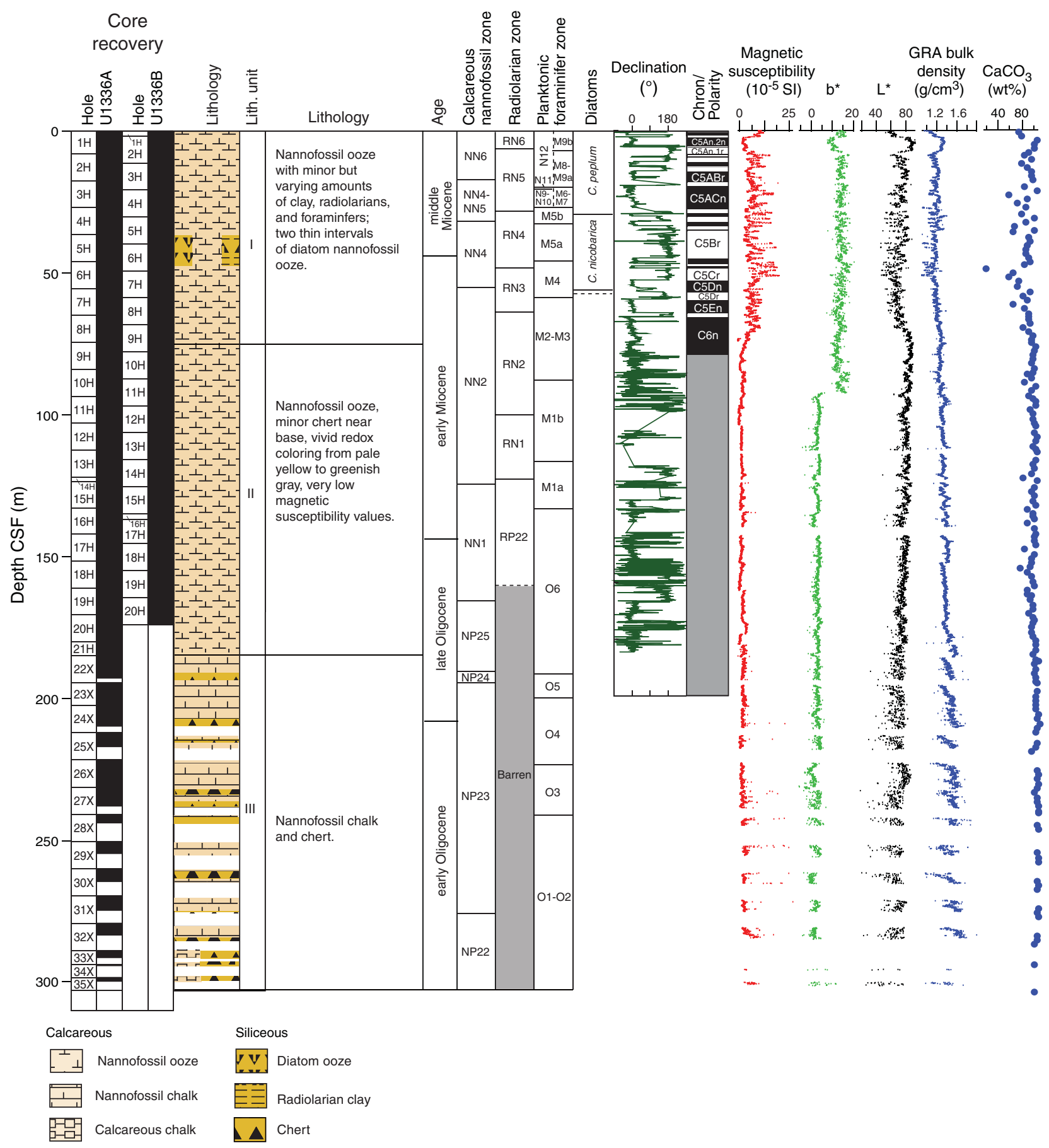


Figure F4. Lithostratigraphy summary, Site U1336. $L^{*}, b^{*}=$ lightness reflectance value of sediment as defined in the LAB color model, GRA = gamma ray attenuation.

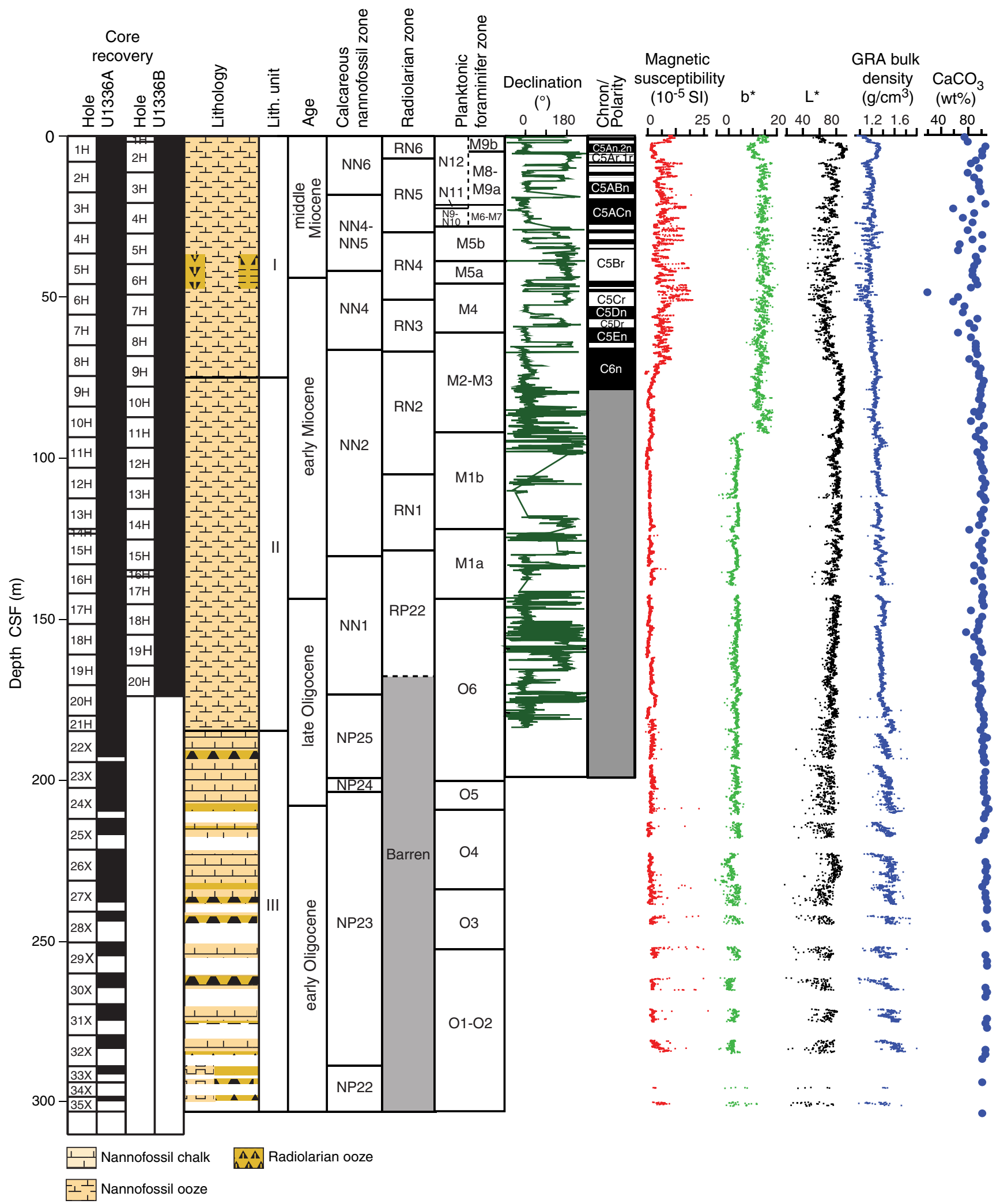


Figure F5. Light-dark sediment alternations of Miocene age including the two diatom-rich intervals. Pie charts show lithologic variability observed in smear slides.

Hole U1336A

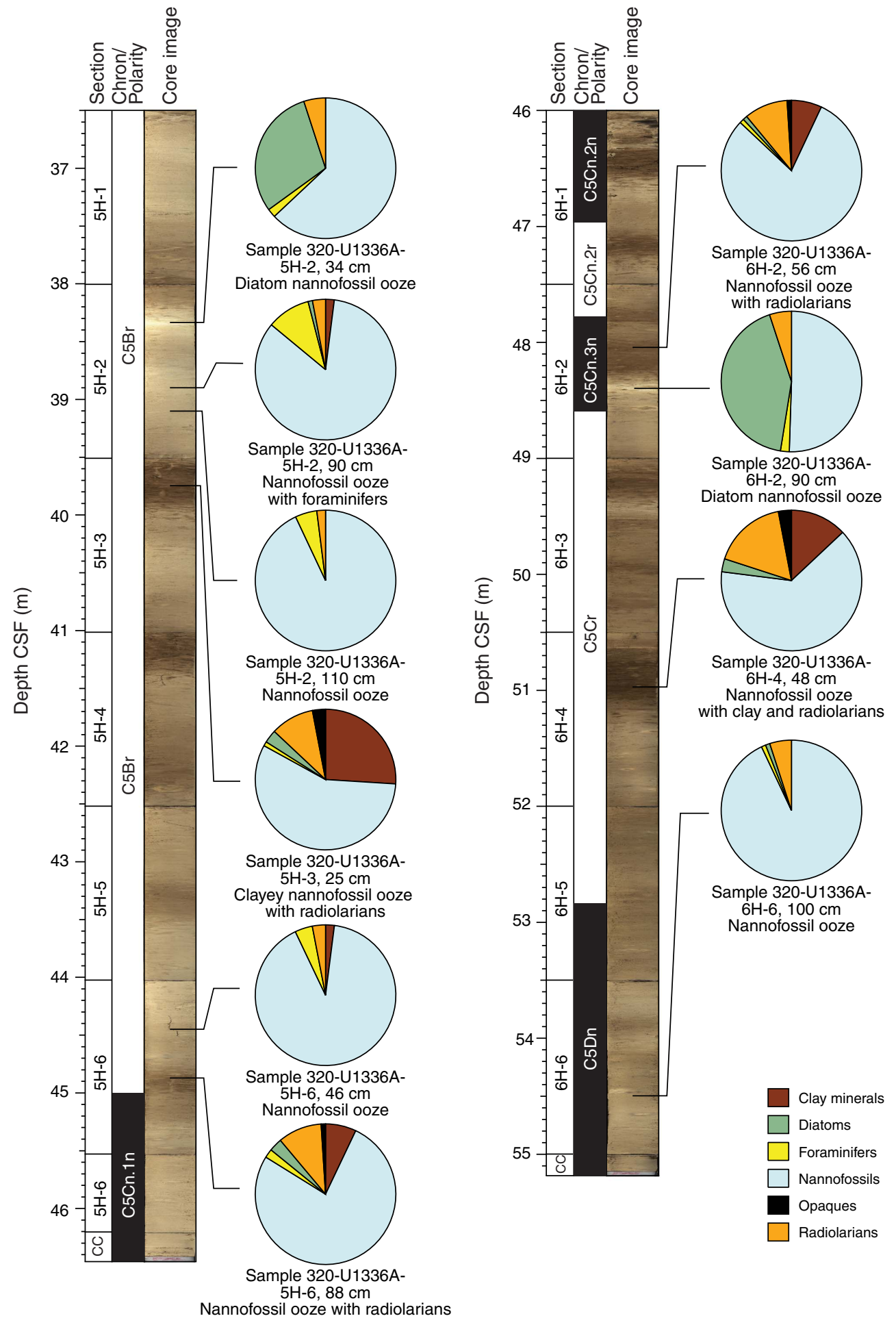


Figure F6. Smear slide photomicrographs of diatom-rich layers and adjacent lithologies. Left image = planepolarized light, right image $=$ cross-polarized light. A. Diatom nannofossil ooze $($ Sample 320-U1336A-5H-2, $34 \mathrm{~cm})$. B. Nannofossil ooze with foraminifers (Sample 320-U1336A-5H-2, $90 \mathrm{~cm}$ ). C. Nannofossil ooze with radiolarians (Sample 320-U1336A-6H-2, $56 \mathrm{~cm}$ ). D. Diatom nannofossil ooze (Sample 320-U1336A-6H-2, $90 \mathrm{~cm}$ ).
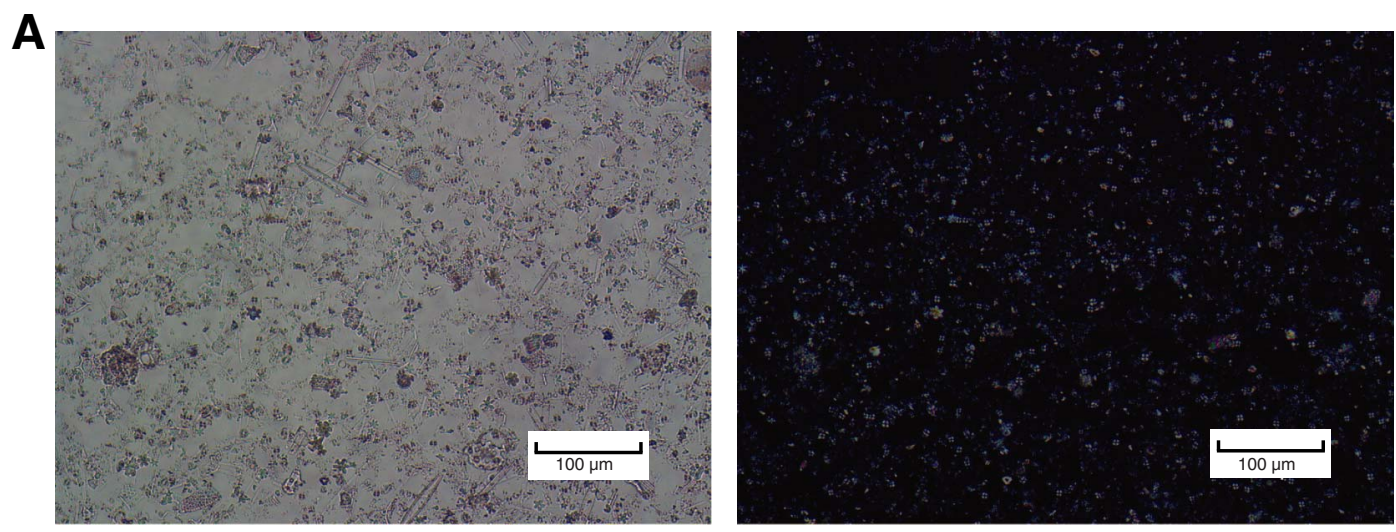

B
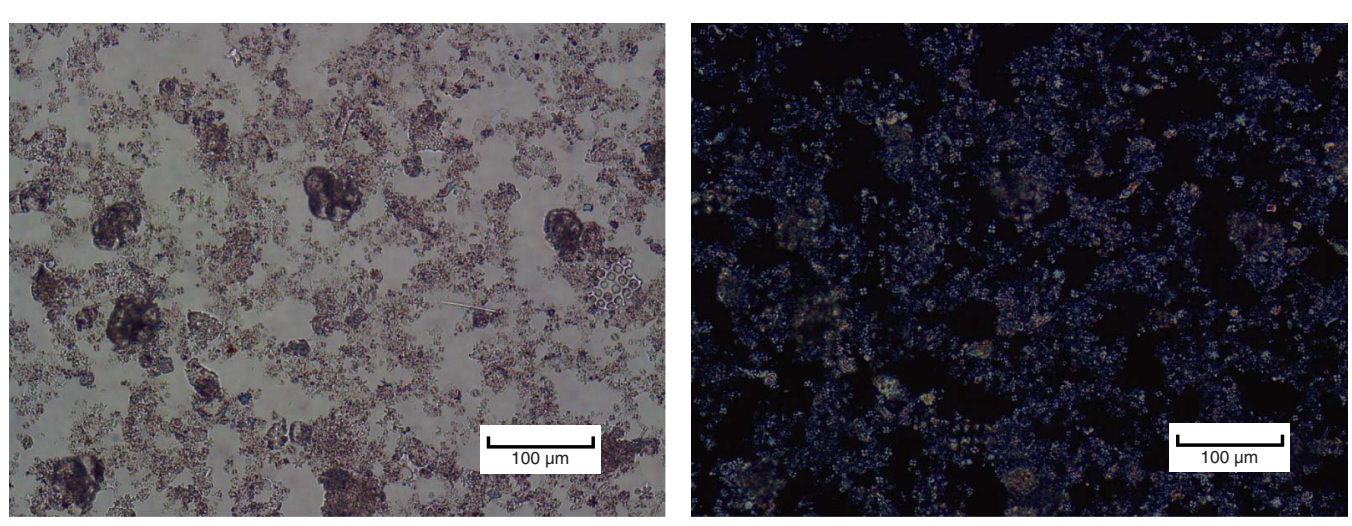

C
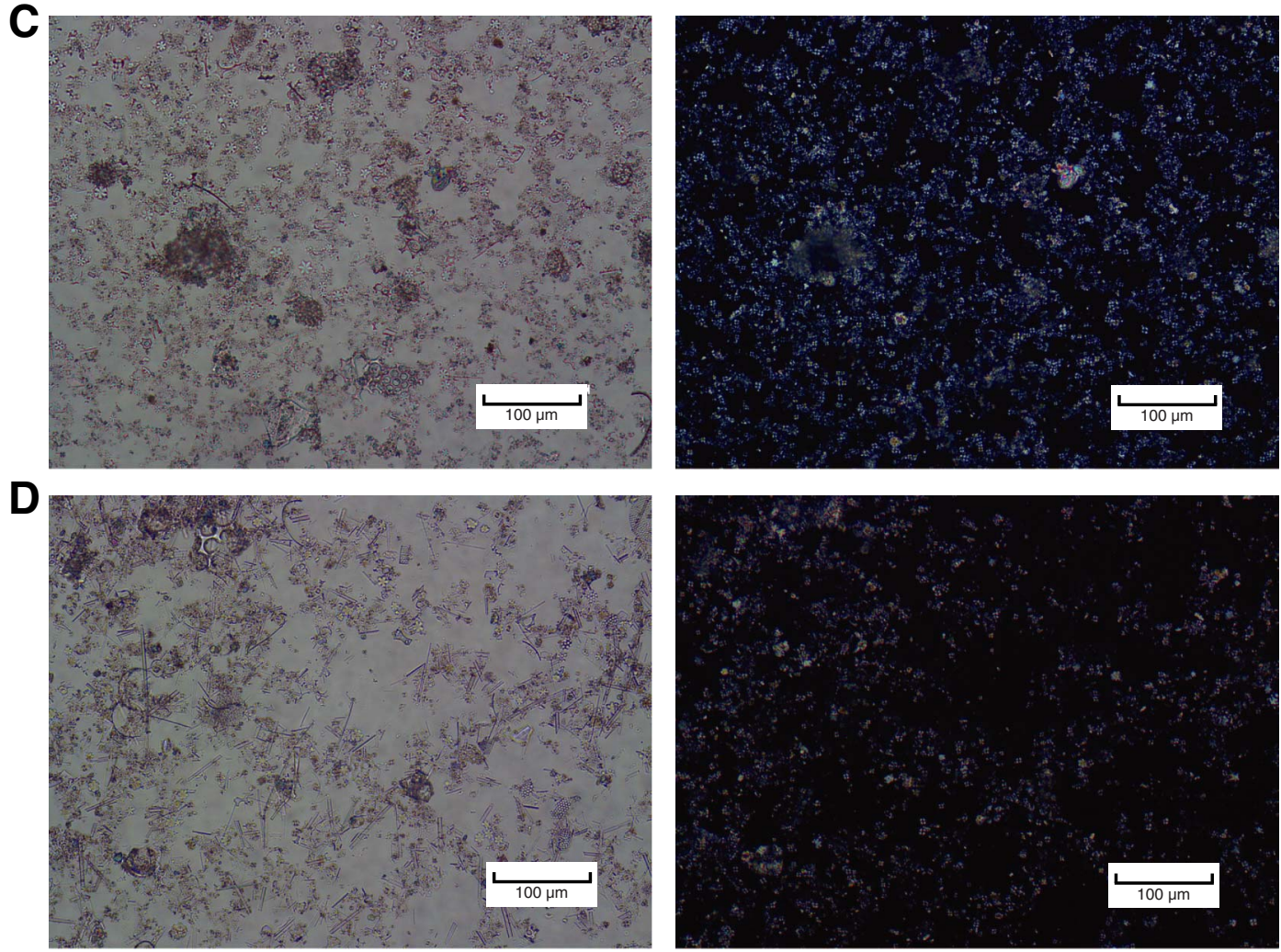
Figure F7. Color reflectance and magnetic susceptibility, Hole U1336A. Line scan images from Cores 320U1336A-8H through $11 \mathrm{H}$ highlight observed color changes. $\mathrm{L}^{*}, \mathrm{a}^{*}, \mathrm{~b}^{*}=$ lightness reflectance value of sediment as defined in the LAB color model.

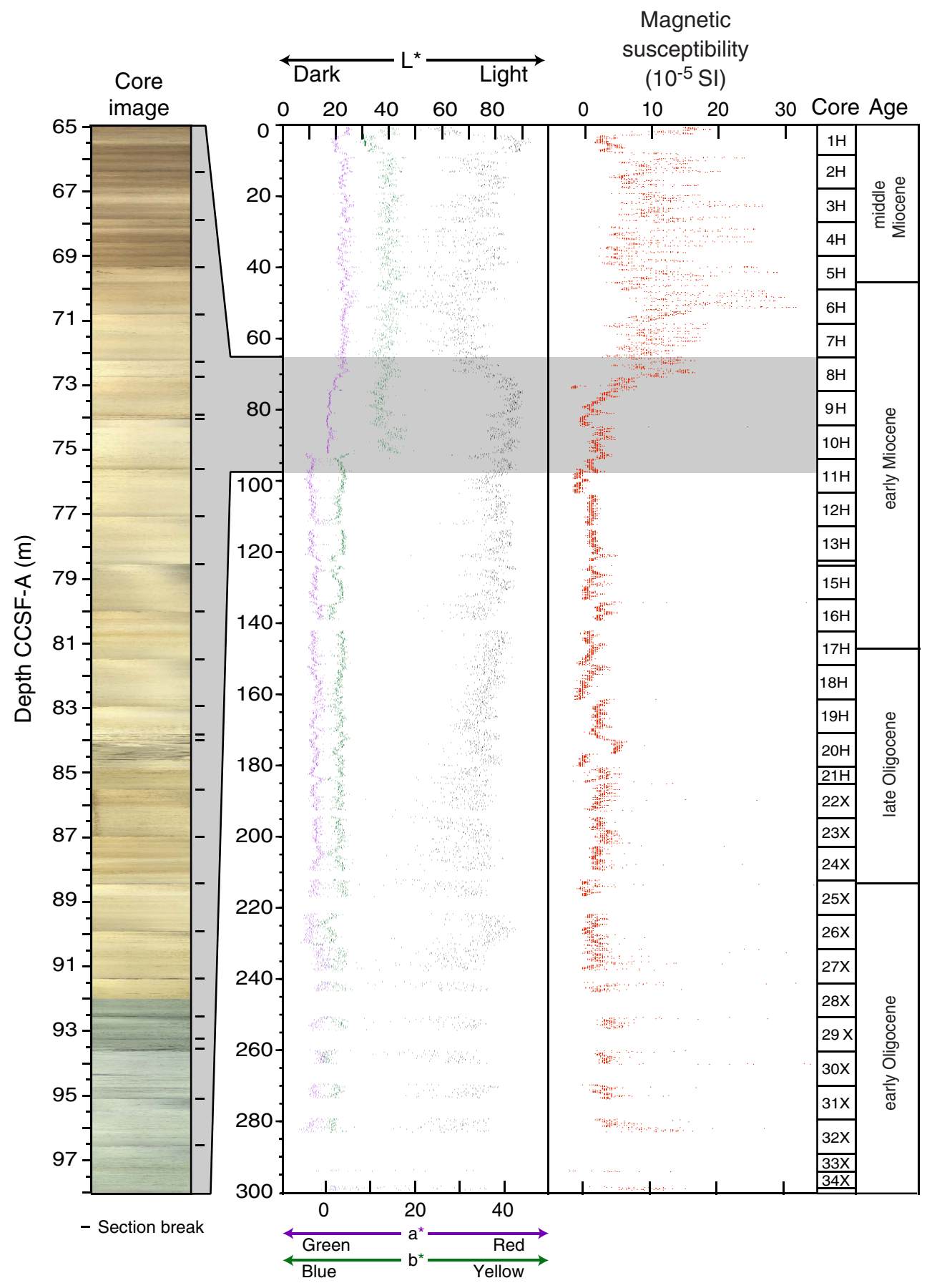


Figure F8. Line scan image of interval 320-U1336A-10H-6, $55-75 \mathrm{~cm}$, showing sharp redox-related color change.

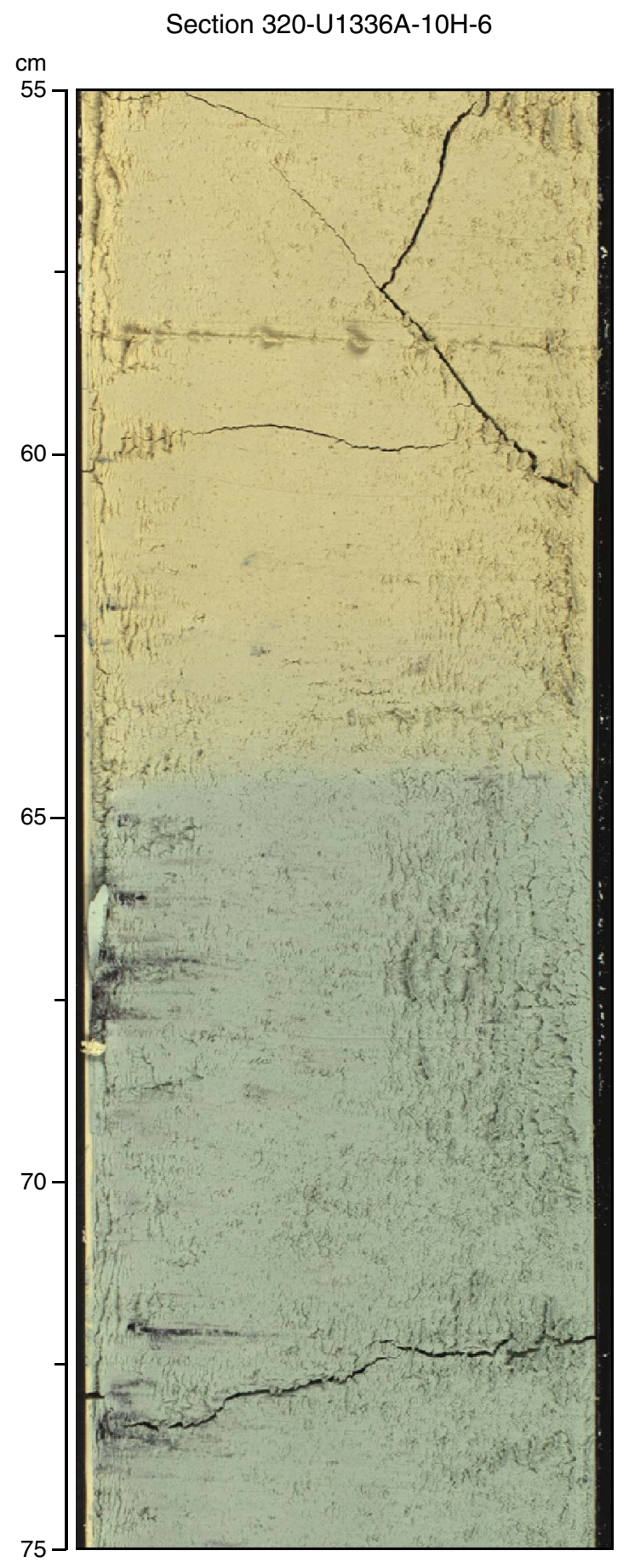


Figure F9. Thin section photomicrographs of foraminifer-bearing cherts, Site U1336. Left image = plane-polarized light, right image $=$ cross-polarized light. A. Sample 320-U1336A-33X-1, 2-3 cm. B. Sample 320-U1336A-35X-1, 78-80 cm. C, D. Sample 320-U1336A-27X-1, 0-2 cm.

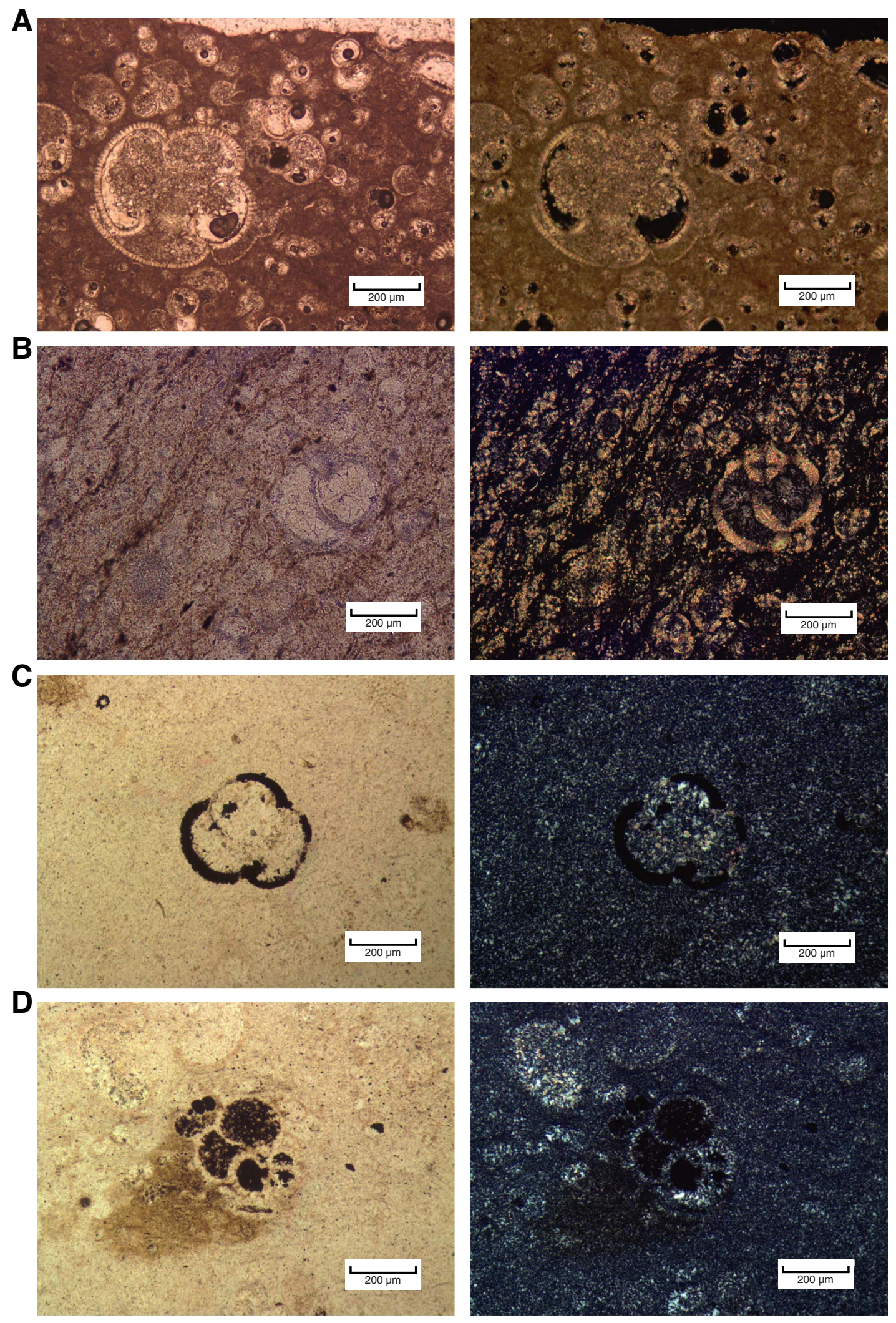


Figure F10. Integrated calcareous and siliceous microfossil biozonation, Site U1336.

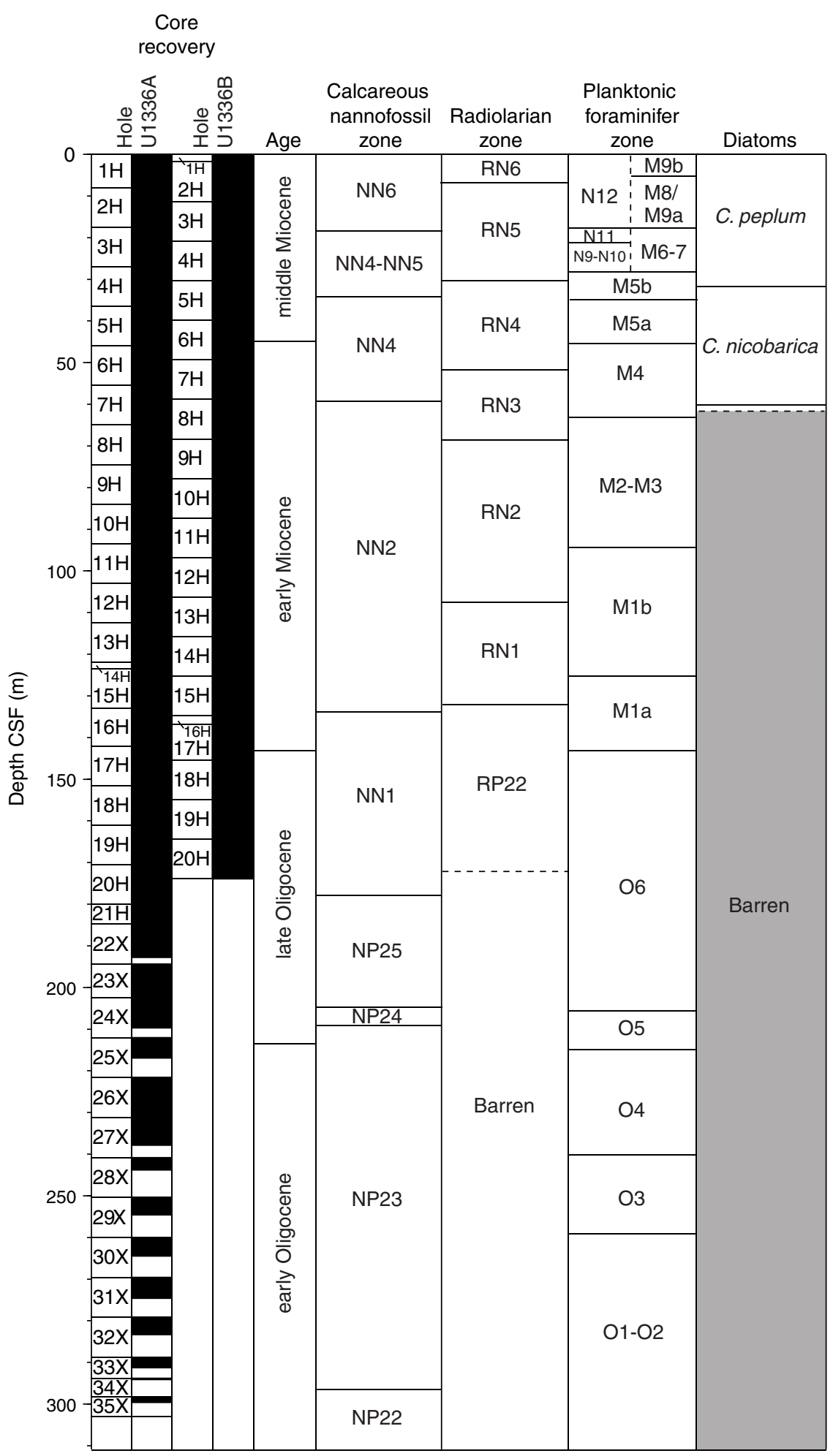


Figure F11. Linear sedimentation rates and chronostratigraphic markers, Site U1336.

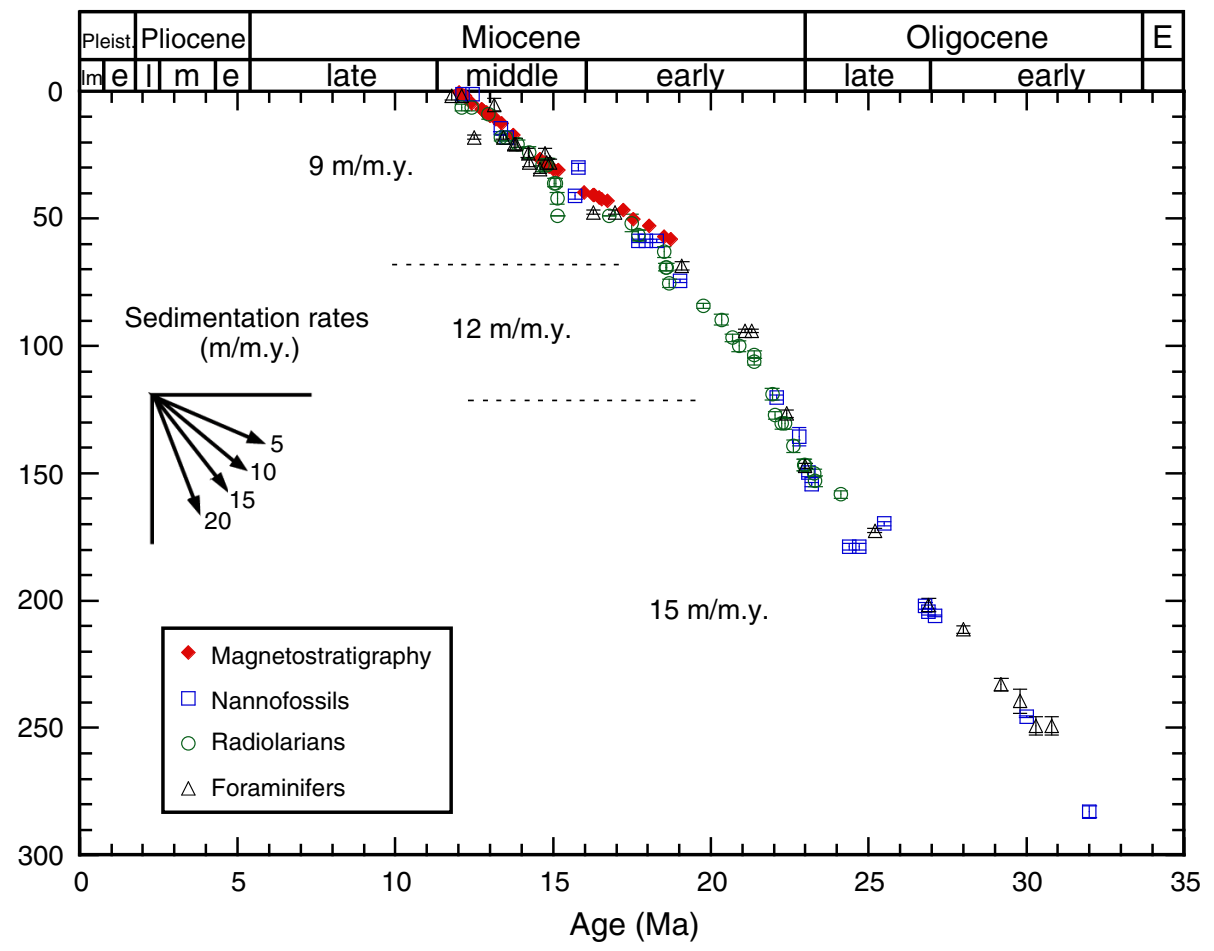


Figure F12. Magnetic susceptibility and paleomagnetic summary, Hole U1336A, 0-100 m CSF. Gray lines = measurements before demagnetization, red lines = measurements after $20 \mathrm{mT}$ alternating-field demagnetization, blue squares $=$ discrete sample data.

Hole U1336A

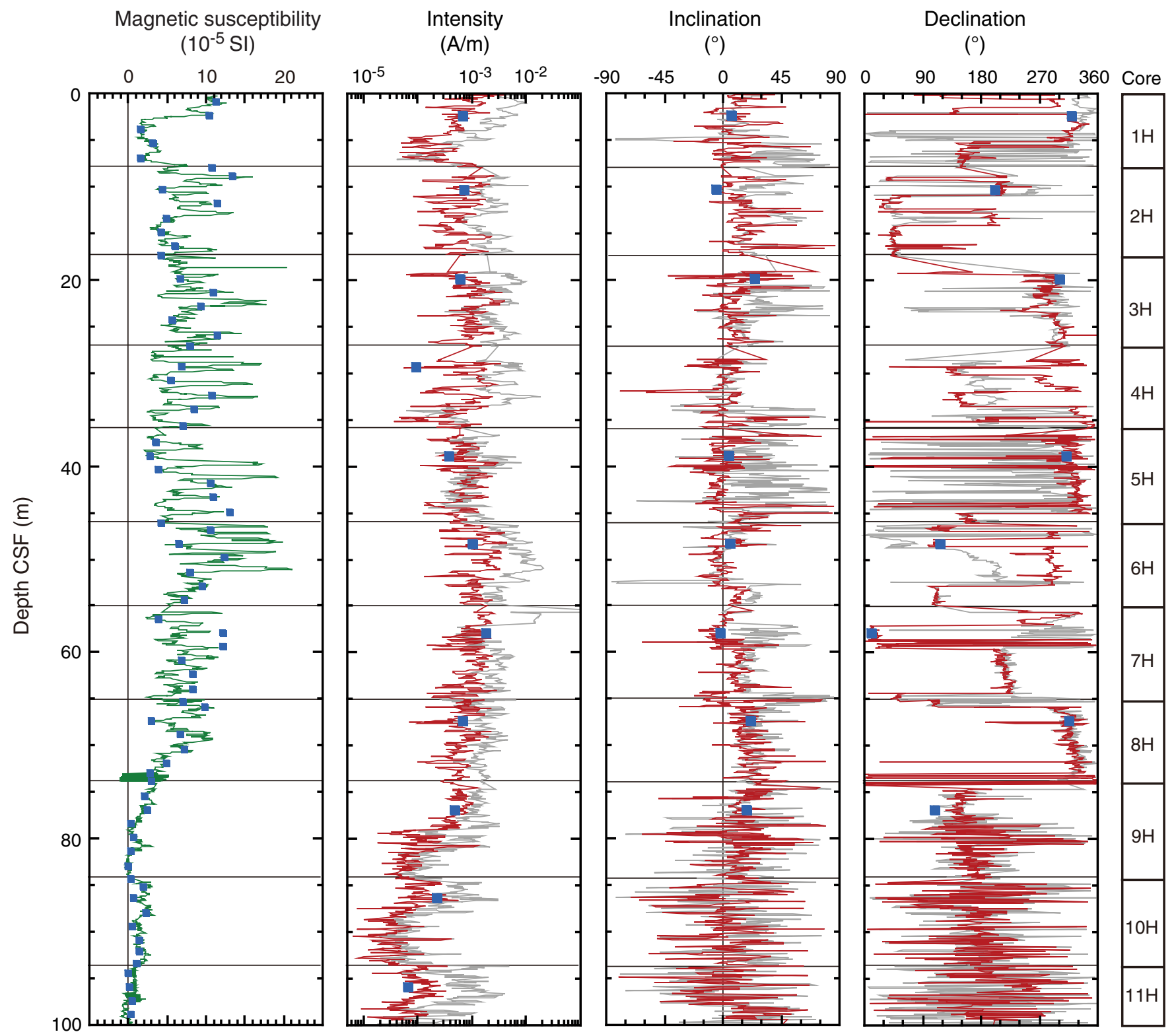


Figure F13. Magnetic susceptibility and paleomagnetic summary, Hole U1336A, 100-200 m CSF. Gray lines = measurements before demagnetization, red lines = measurements after $20 \mathrm{mT}$ alternating-field demagnetization, blue squares $=$ discrete sample data.

Hole U1336A

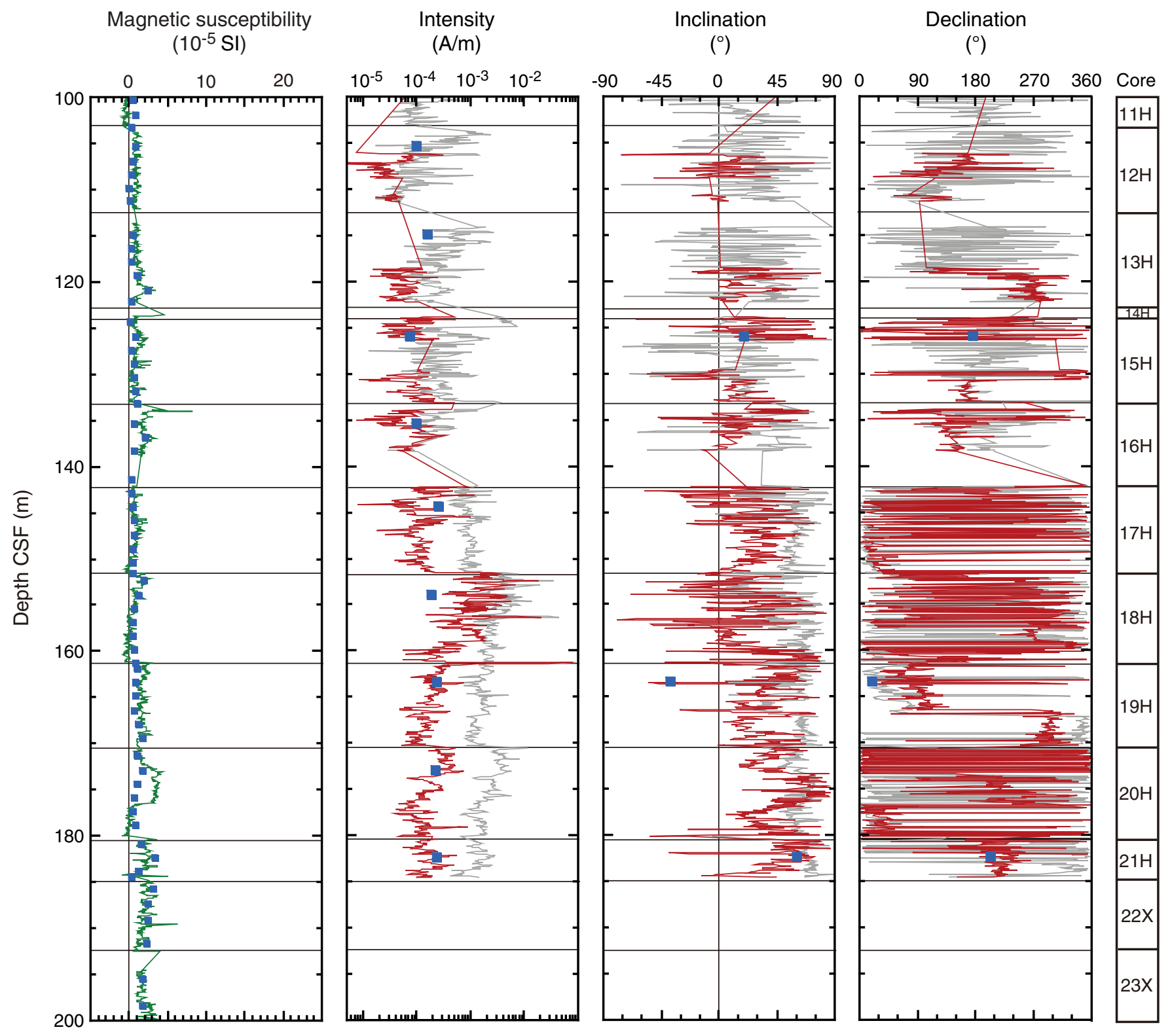


Figure F14. Magnetic susceptibility and paleomagnetic summary, Hole U1336B, 0-100 m CSF. Gray lines = measurements before demagnetization, red lines = measurements after $20 \mathrm{mT}$ alternating-field demagnetization.

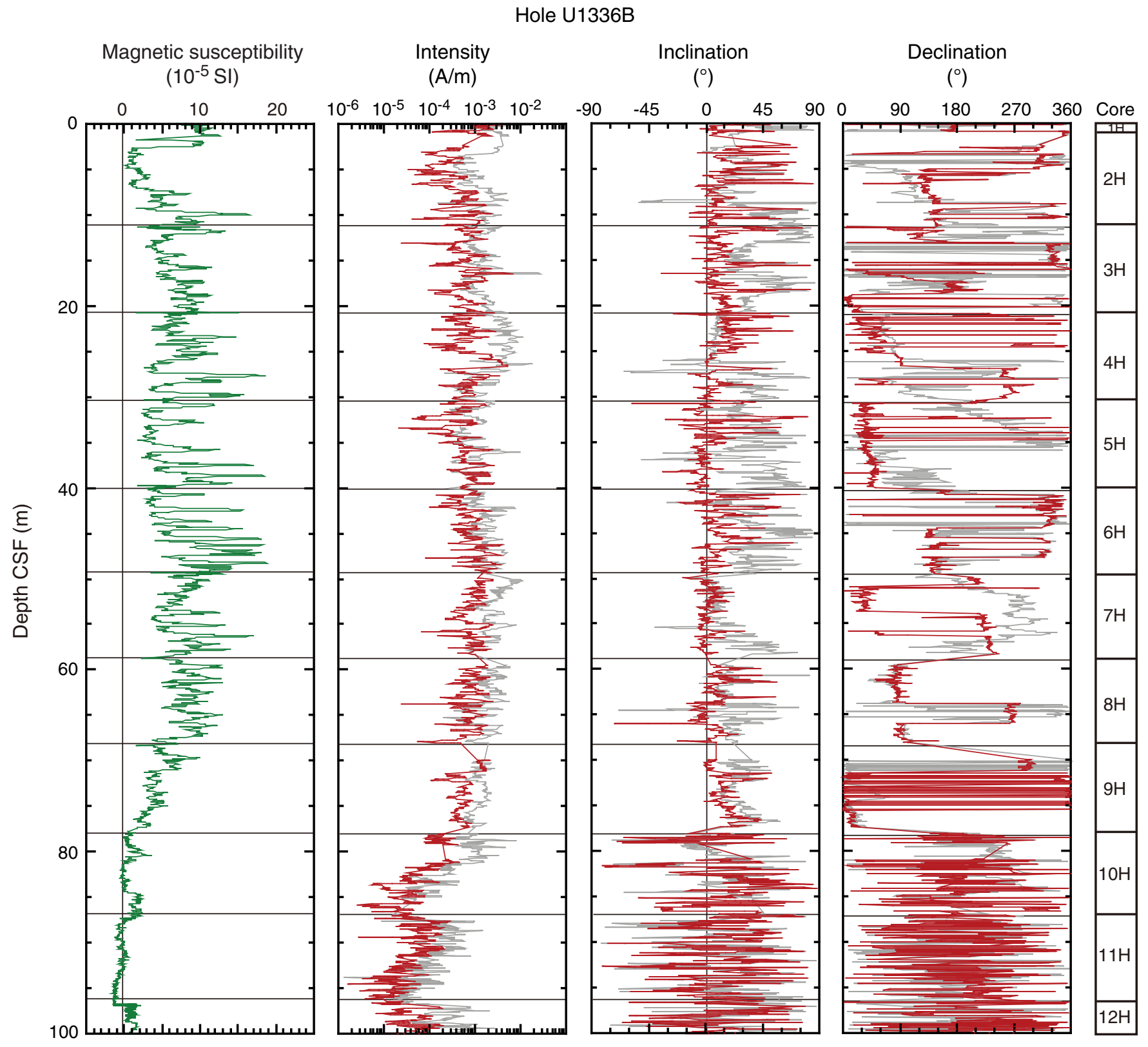


Figure F15. Magnetic susceptibility and paleomagnetic summary, Hole U1336B, 100-180 m CSF. Gray lines = measurements before demagnetization, red lines = measurements after $20 \mathrm{mT}$ alternating-field demagnetization.

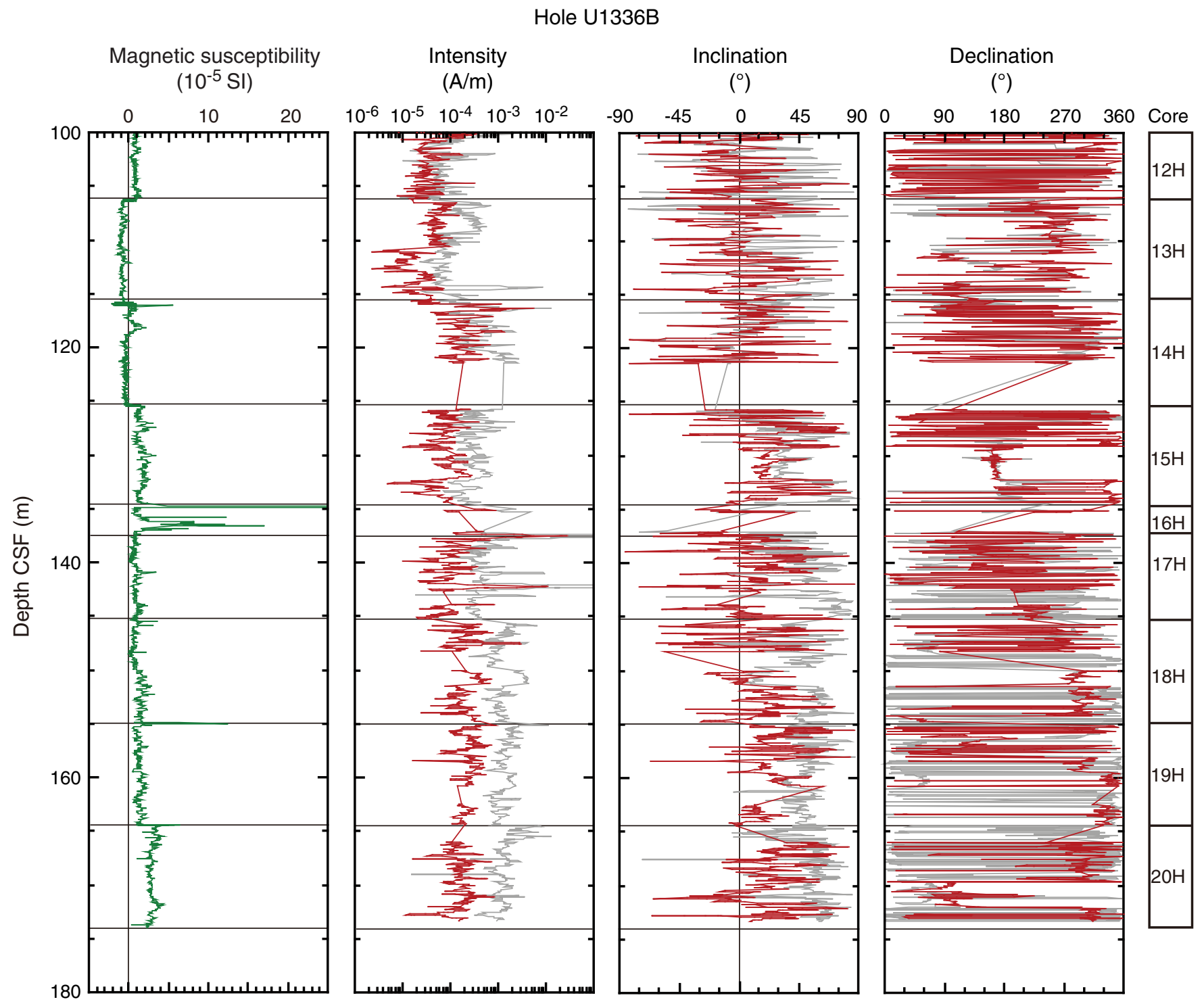


Figure F16. Declination of natural remanent magnetization after $20 \mathrm{mT}$ alternating-field demagnetization. Red = cores. Note that in this interpretation polarity zones corresponding to Chrons C5ADn and C5ACn are concatenated into a single polarity zone, with Chron C5ACr not recorded. CCSF-A depths for holes were determined independent of the polarity record. See Table T15.

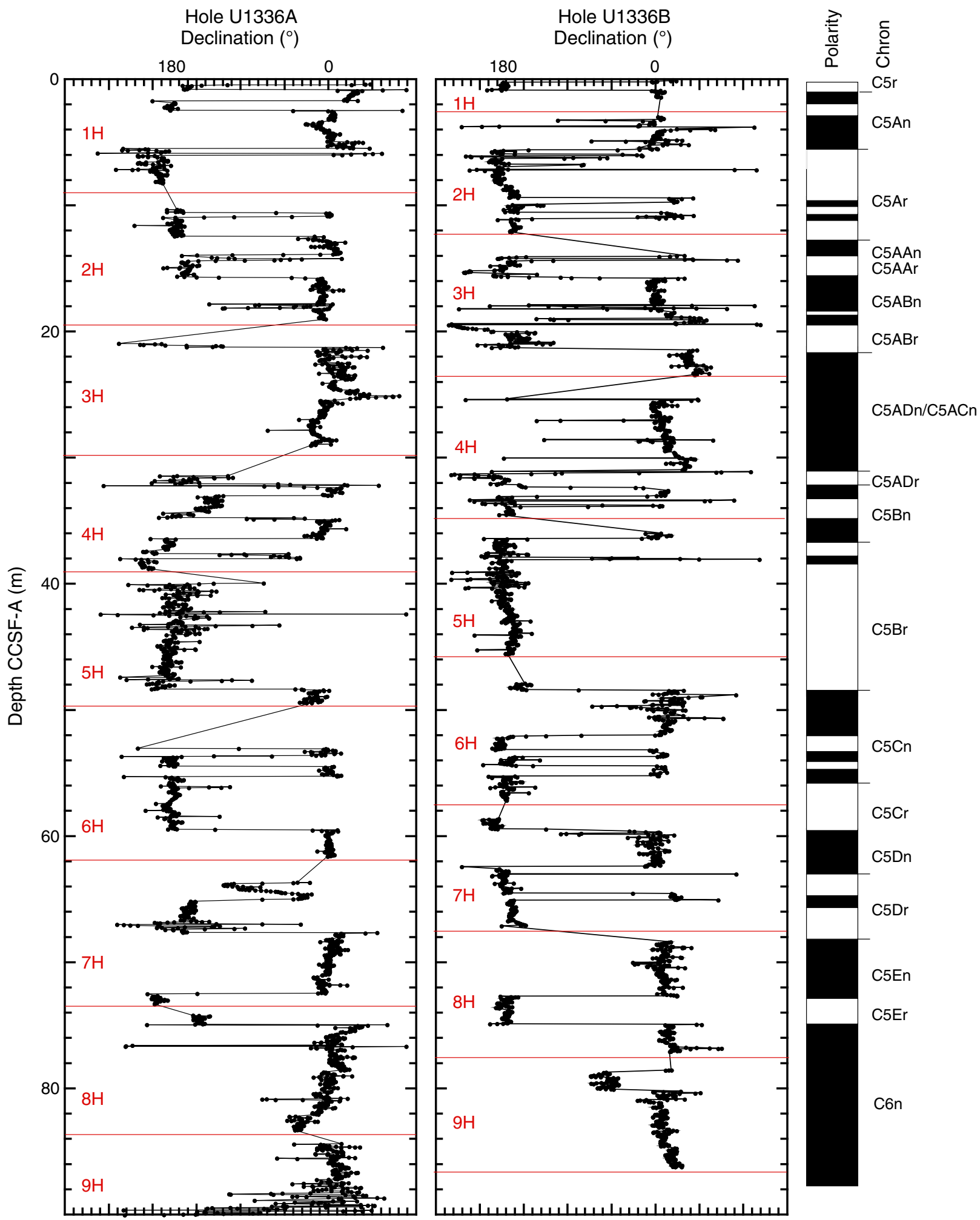


Figure F17. Alternating-field (AF) demagnetization results representative of Site U1336 discrete samples. Left plot $=$ vector endpoints of paleomagnetic directions on vector demagnetization diagrams or modified Zijderveld plots (open squares $=$ inclinations [Inc], solid squares $=$ declinations [Dec]), top right plot $=$ intensity variation with progressive demagnetization, bottom right plot $=$ directions plotted on an equal-area stereonet. Data in A and B illustrate removal of a drilling overprint by $\sim 10 \mathrm{mT}$, with remaining magnetization providing a relatively well-resolved characteristic remanent magnetization. $\mathrm{C}$ shows a sample from base of the hole, illustrating that a steep drilling overprint is dominant and a stable ChRM is not isolated during AF demagnetization. Maximum angular deviation (MAD) values provide an estimate quality of principal component analysis (PCA), where values $<10$ indicate good agreement between PCA vector and paleomagnetic data. See Table T14. A. Hole U1336A (2.35 m CSF). B. Hole U1336A (10.35 m CSF). C. Hole U1336A (172.85 m CSF).
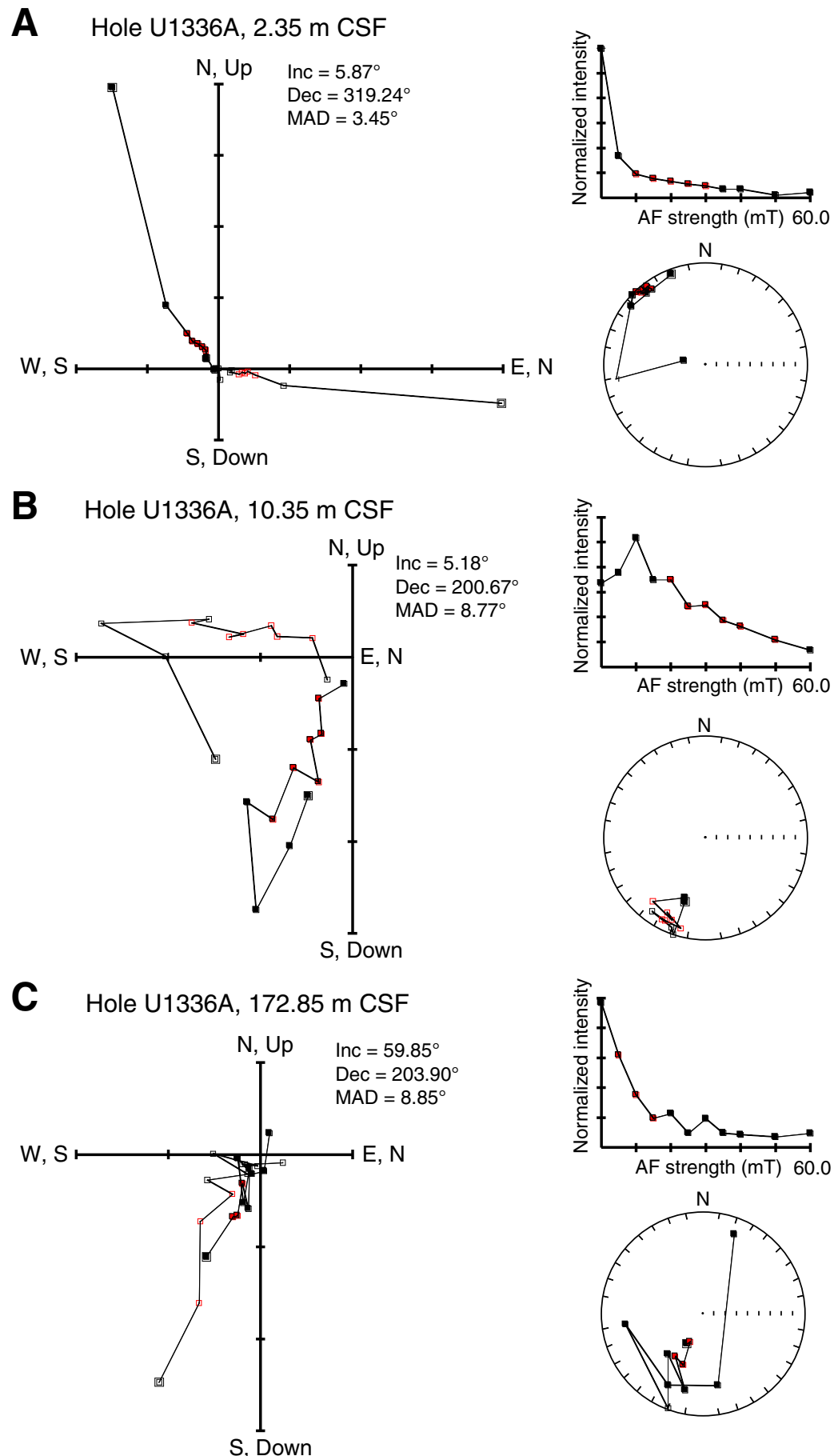
Figure F18. Interstitial water chemistry, Hole U1336B. Values below detection limit (see Table T16) plotted as zero.

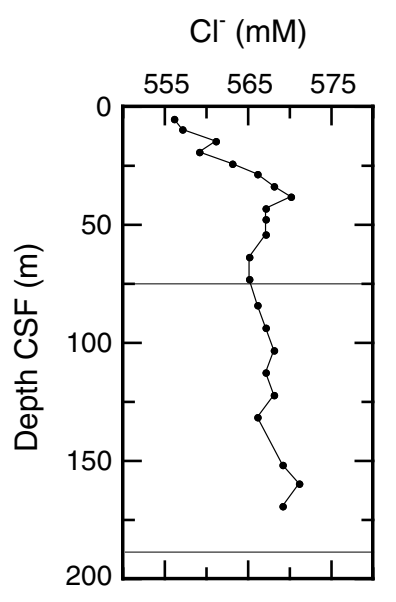

$$
\text { Alkalinity (mM) }
$$
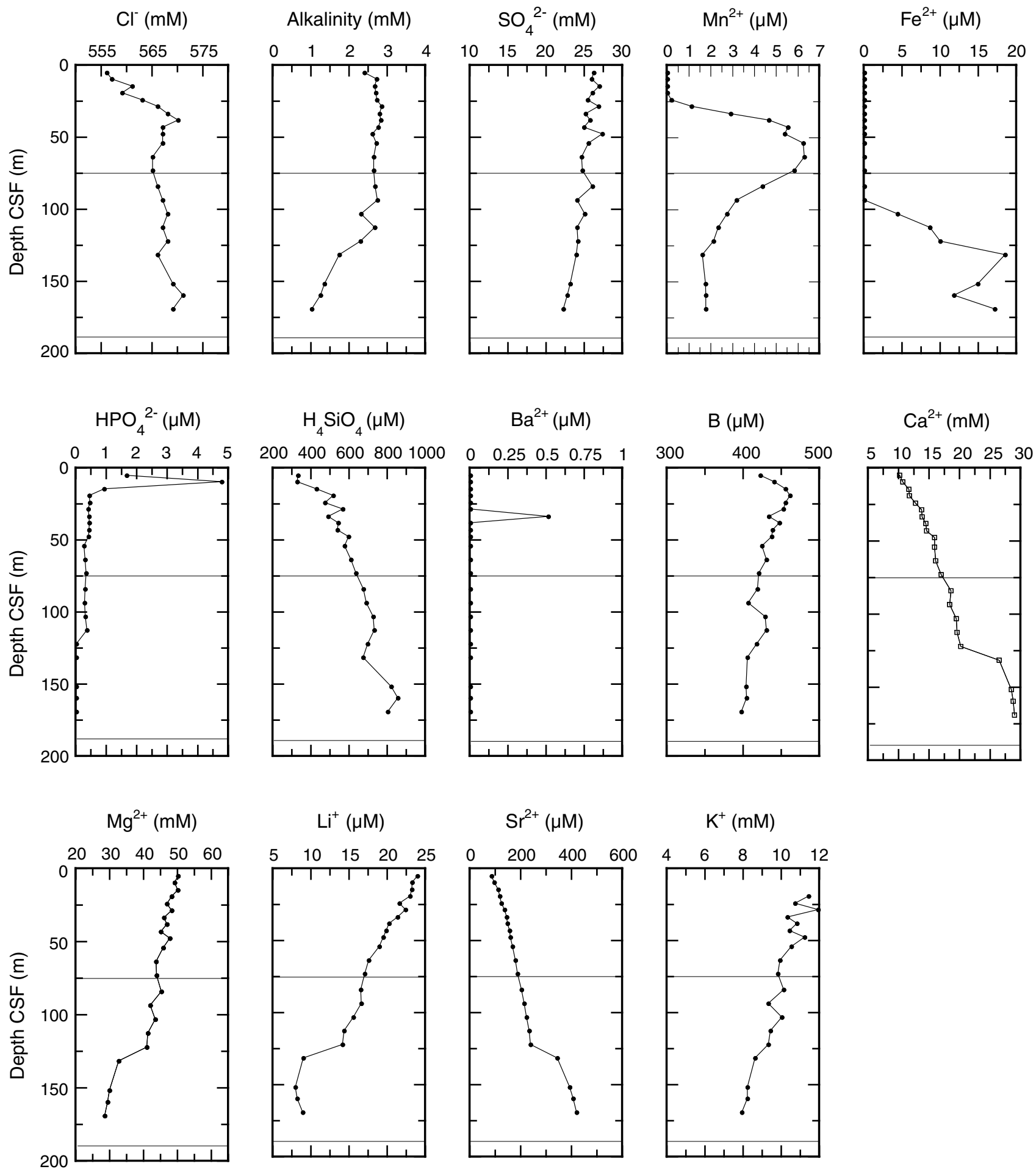
Figure F19. Calcium carbonate in sediments, Holes U1336A and U1336B. Total organic carbon (TOC) content from Hole U1336B.

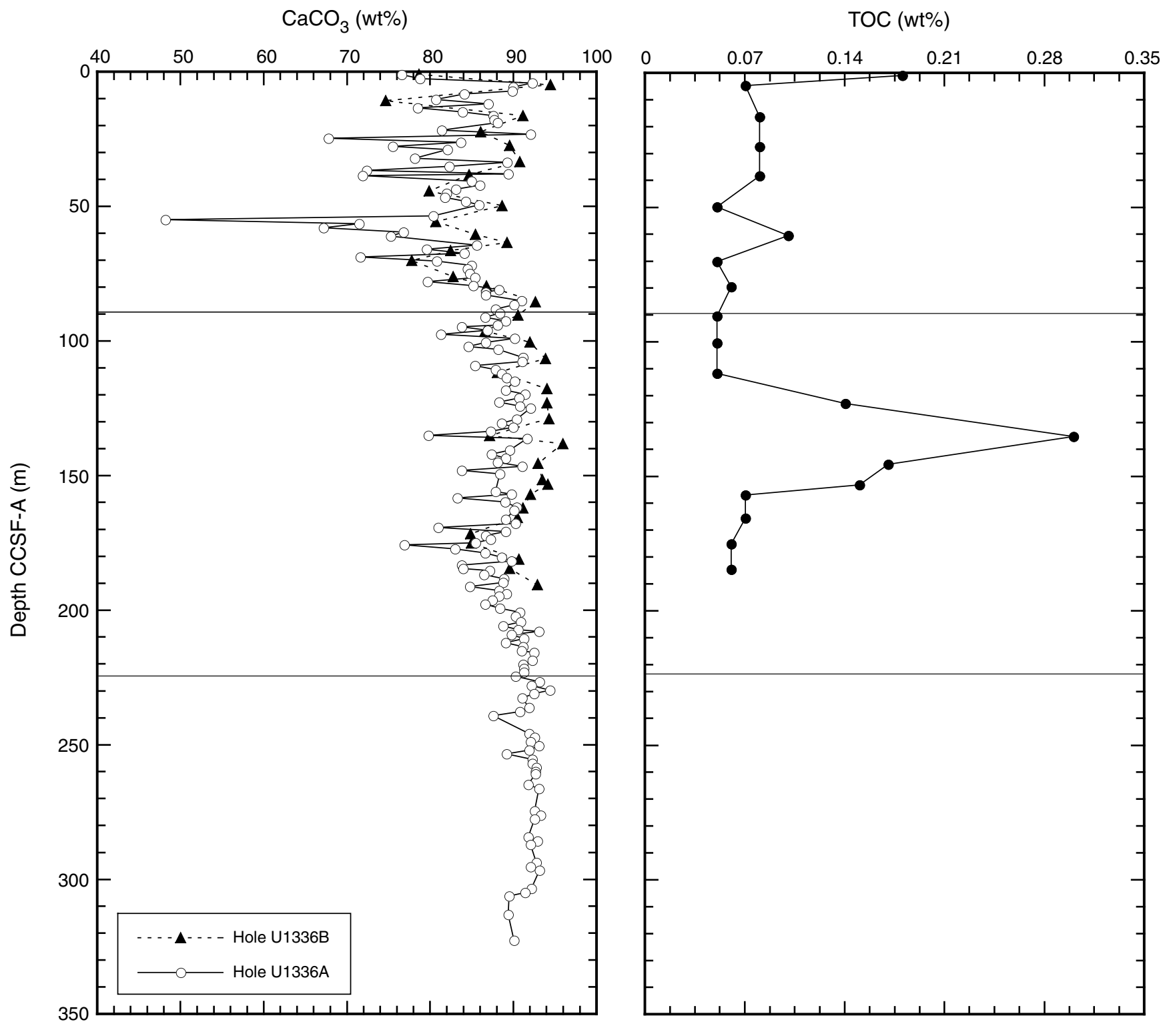


Figure F20. Whole-round measurements, Holes U1336A (black) and U1336B (red). Data for Hole U1336B are plotted using offsets of $0.5 \mathrm{~g} / \mathrm{cm}^{3}$ for bulk density, $30 \times 10^{-5} \mathrm{SI}$ for magnetic susceptibility, $100 \mathrm{~m} / \mathrm{s}$ for $P$-wave velocity, and $10 \mathrm{cps}$ for natural gamma radiation.

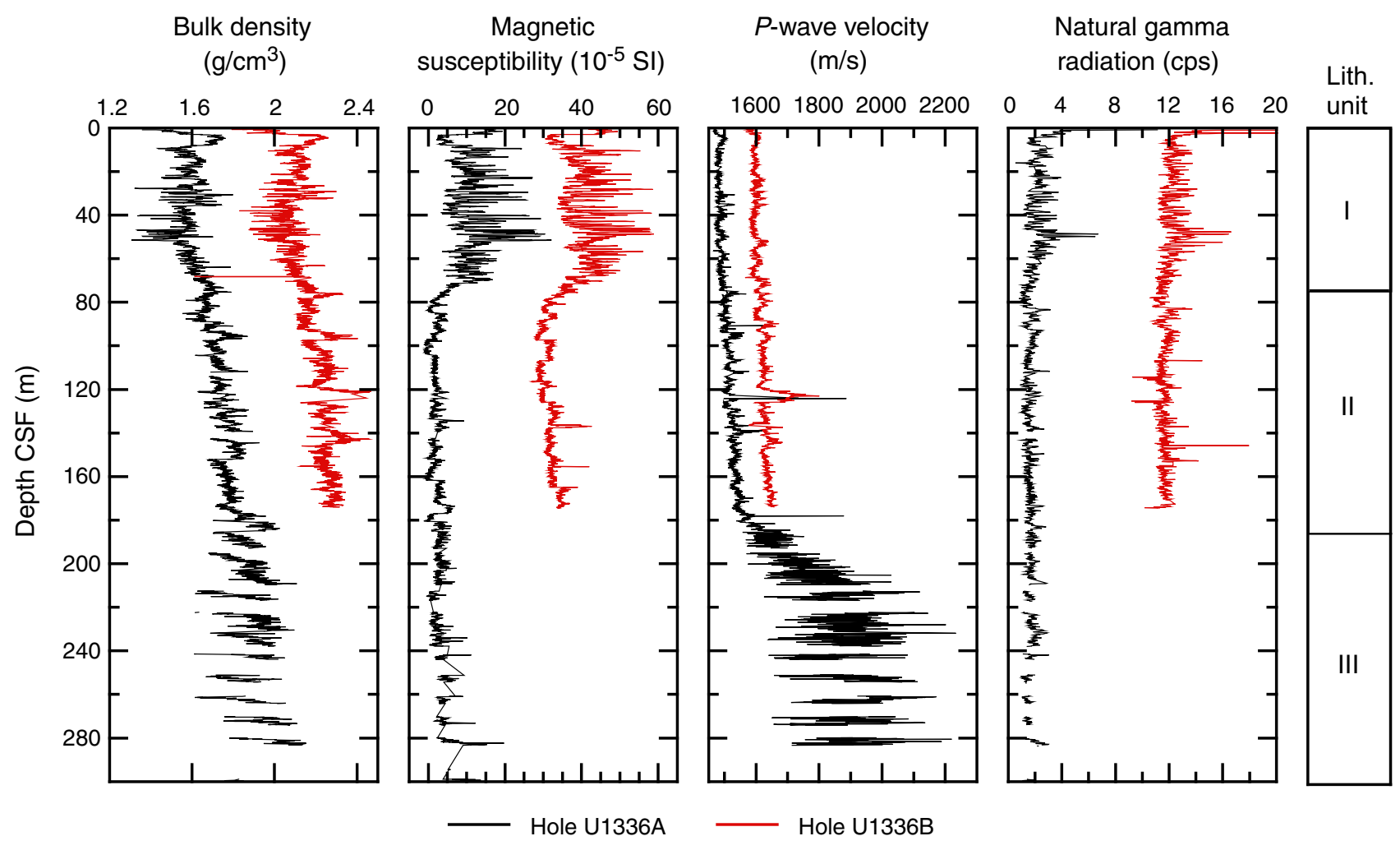


Figure F21. MAD measurements, Holes U1336A (black) and U1336B (red). A. Porosity (solid circles) and water content (open circles). B. Discrete-sample wet bulk density (solid circles) and gamma ray attenuation (GRA) bulk density (gray line). C. Grain density.

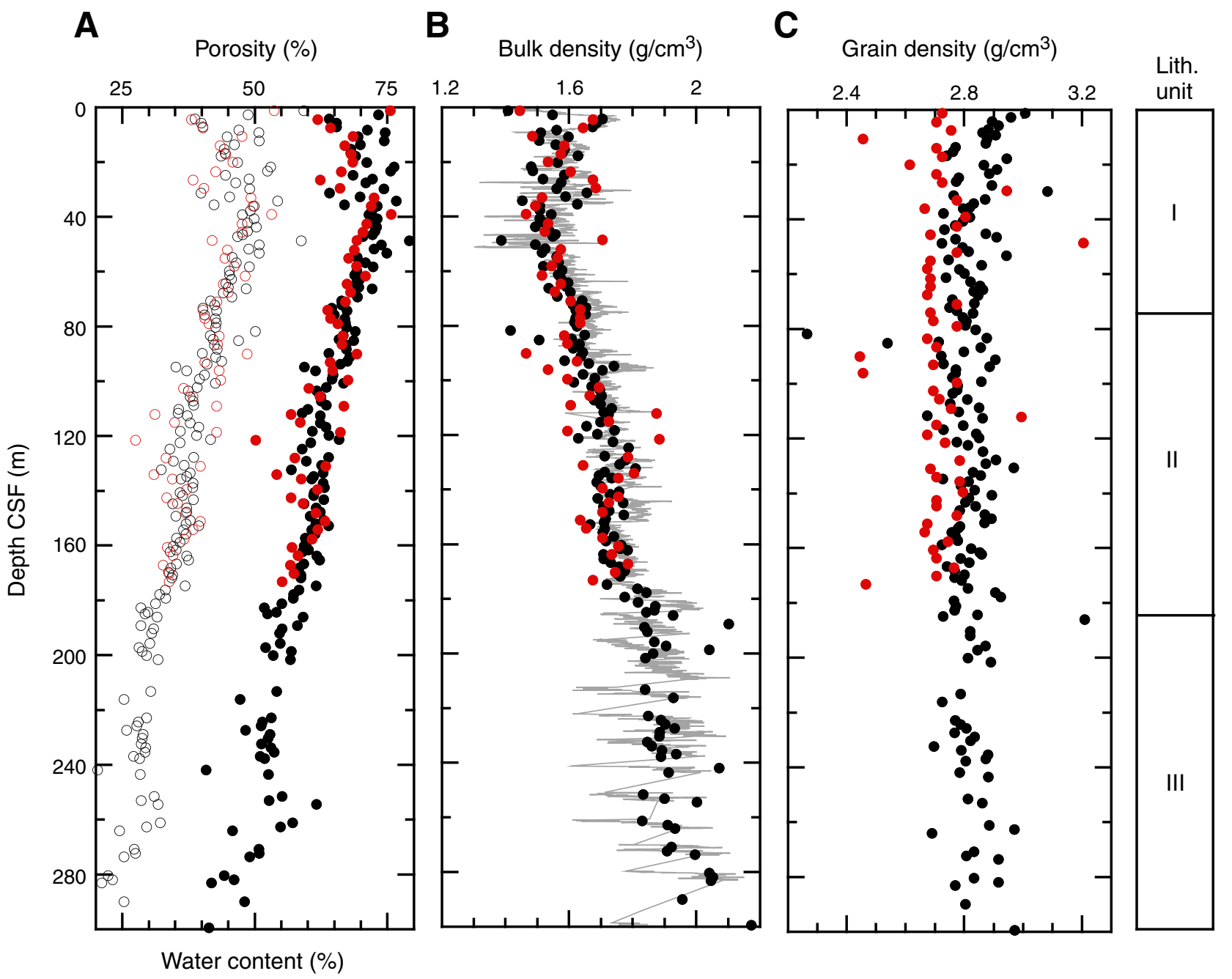


Figure F22. (A) Wet and (B) dry bulk density from MAD analysis of discrete samples from Holes U1336A (black) and U1336B (red) plotted with gamma ray attenuation (GRA) bulk density interpolated with a $20 \mathrm{~cm}$ wide Gaussian window.

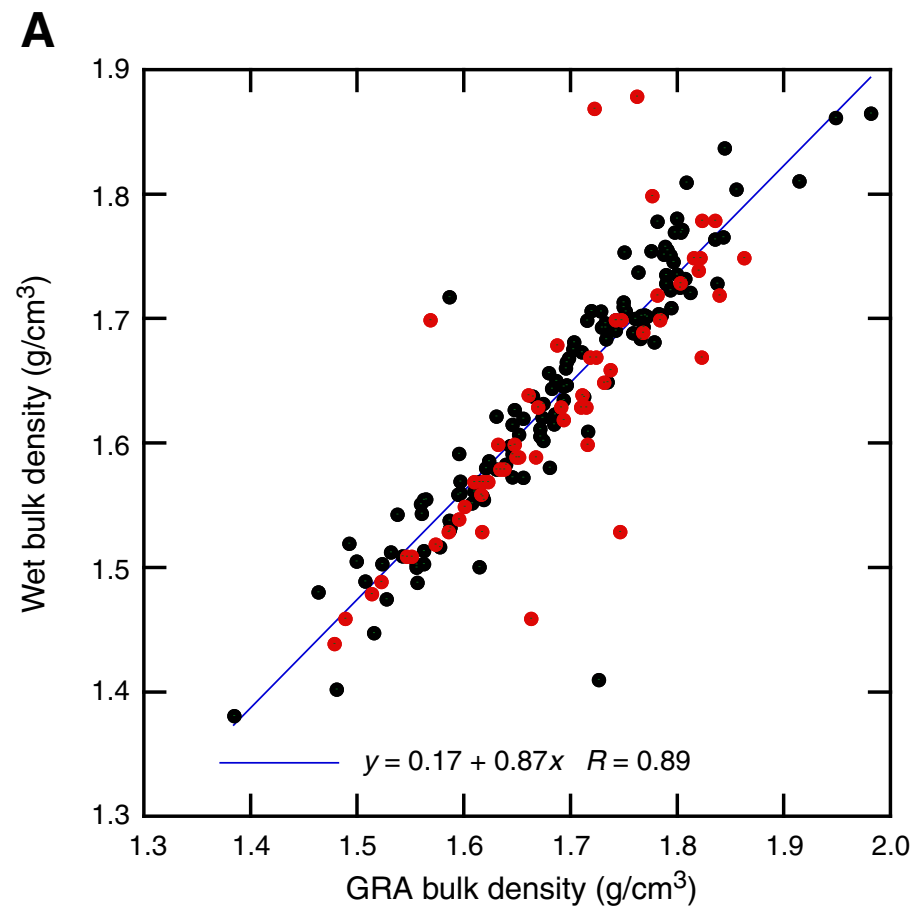

B

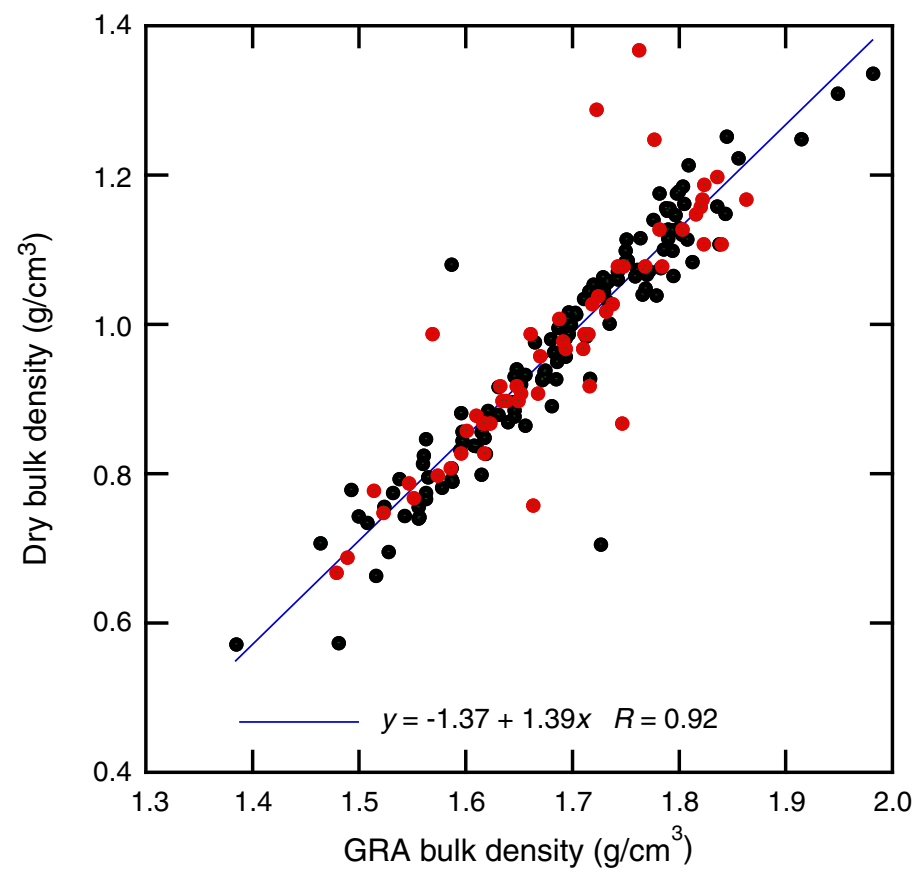


Figure F23. Compressional wave velocity from the PWL (gray lines) and discrete velocity measurements on split core using the contact probe for $x$-axis measurements and insertion probes for $y$ - and $z$-axis measurements. Black circles $=$ Hole U1336A, red circles $=$ Hole U1336B. (See "Compressional wave velocity" for a note on postcruise velocity correction.)

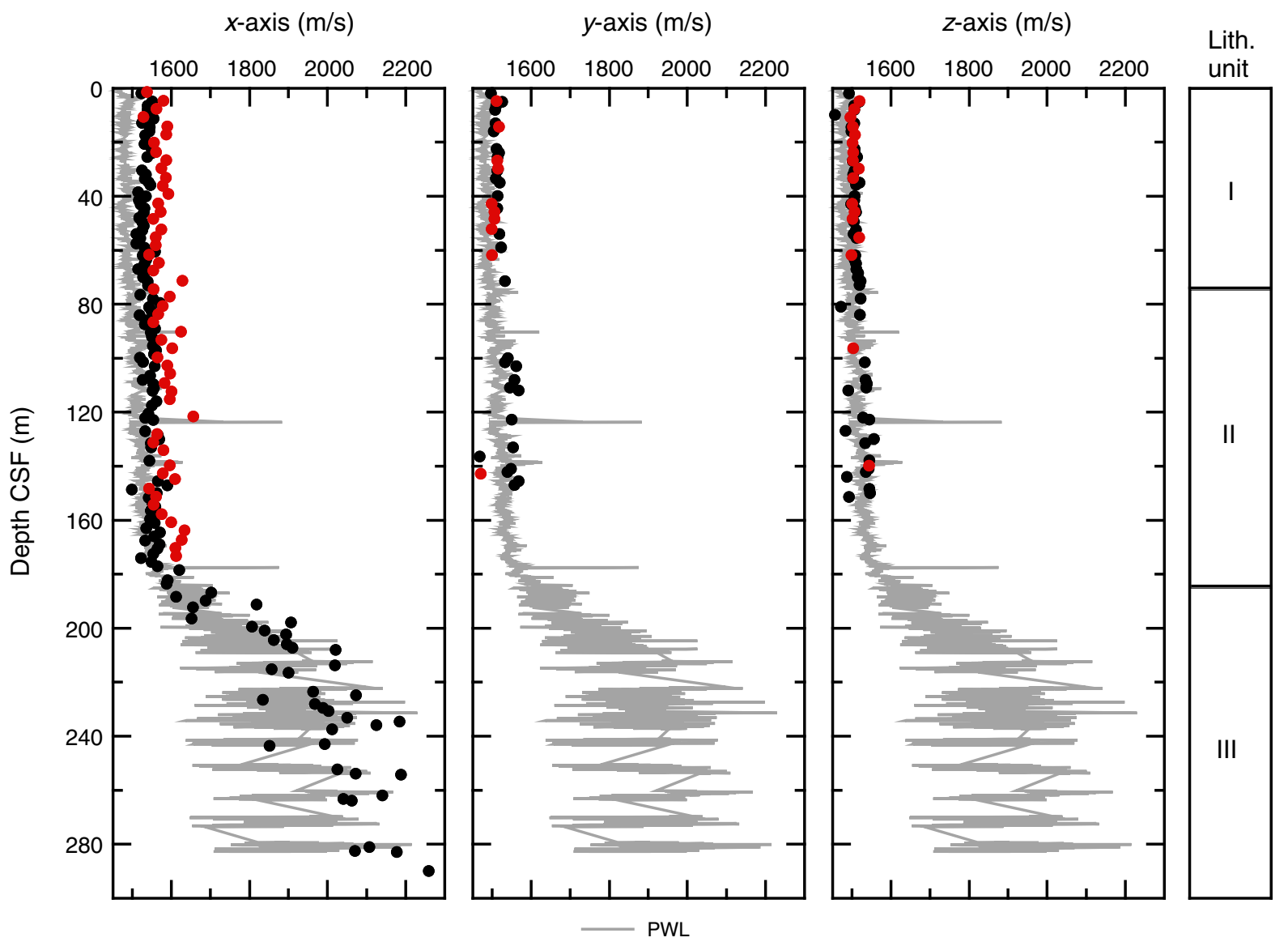


Figure F24. Thermal conductivity vs. depth, Holes U1336A (black) and U1336B (red).

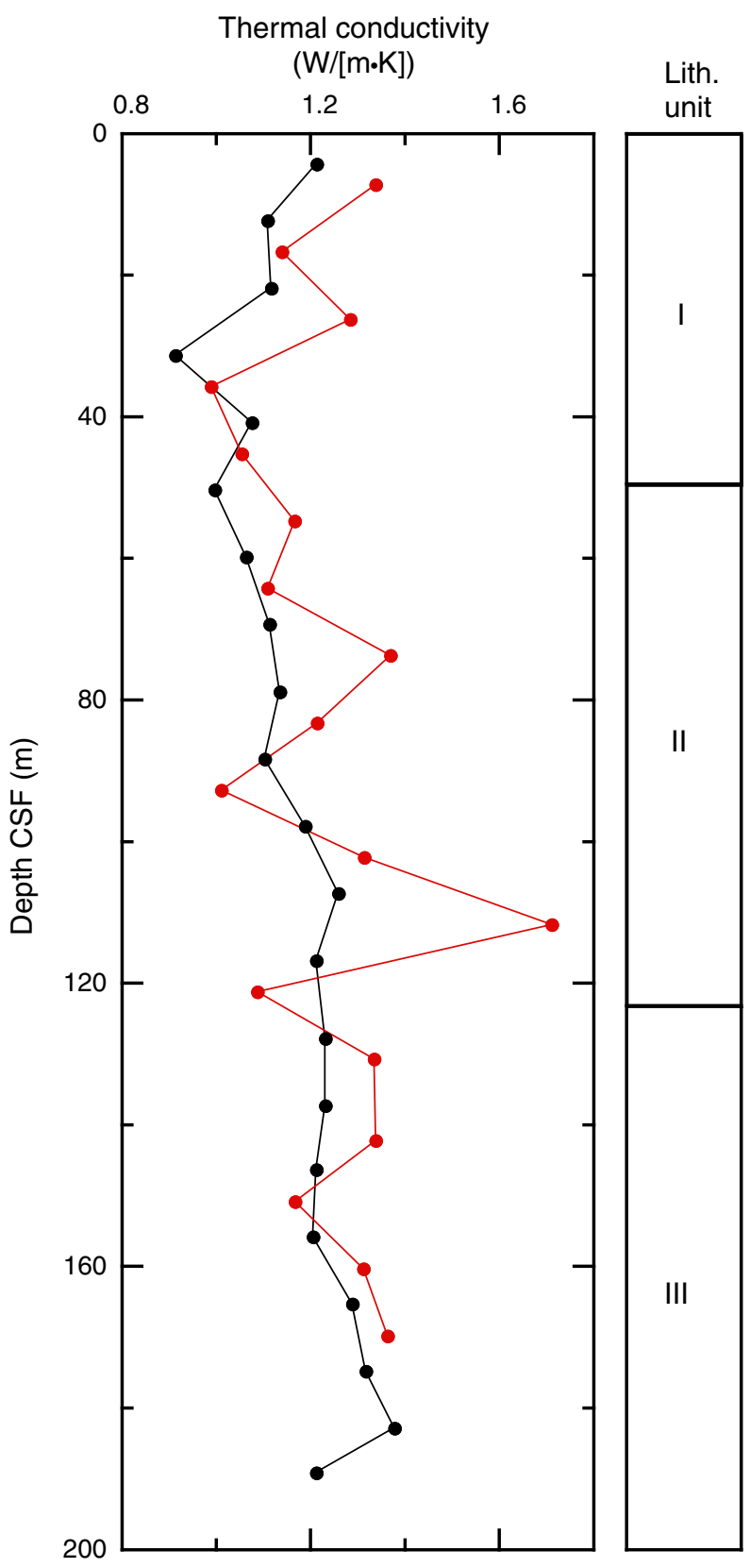


Figure F25. Thermal conductivity vs. porosity from MAD analysis of discrete samples, Holes U1336A (black) and U1336B (red).

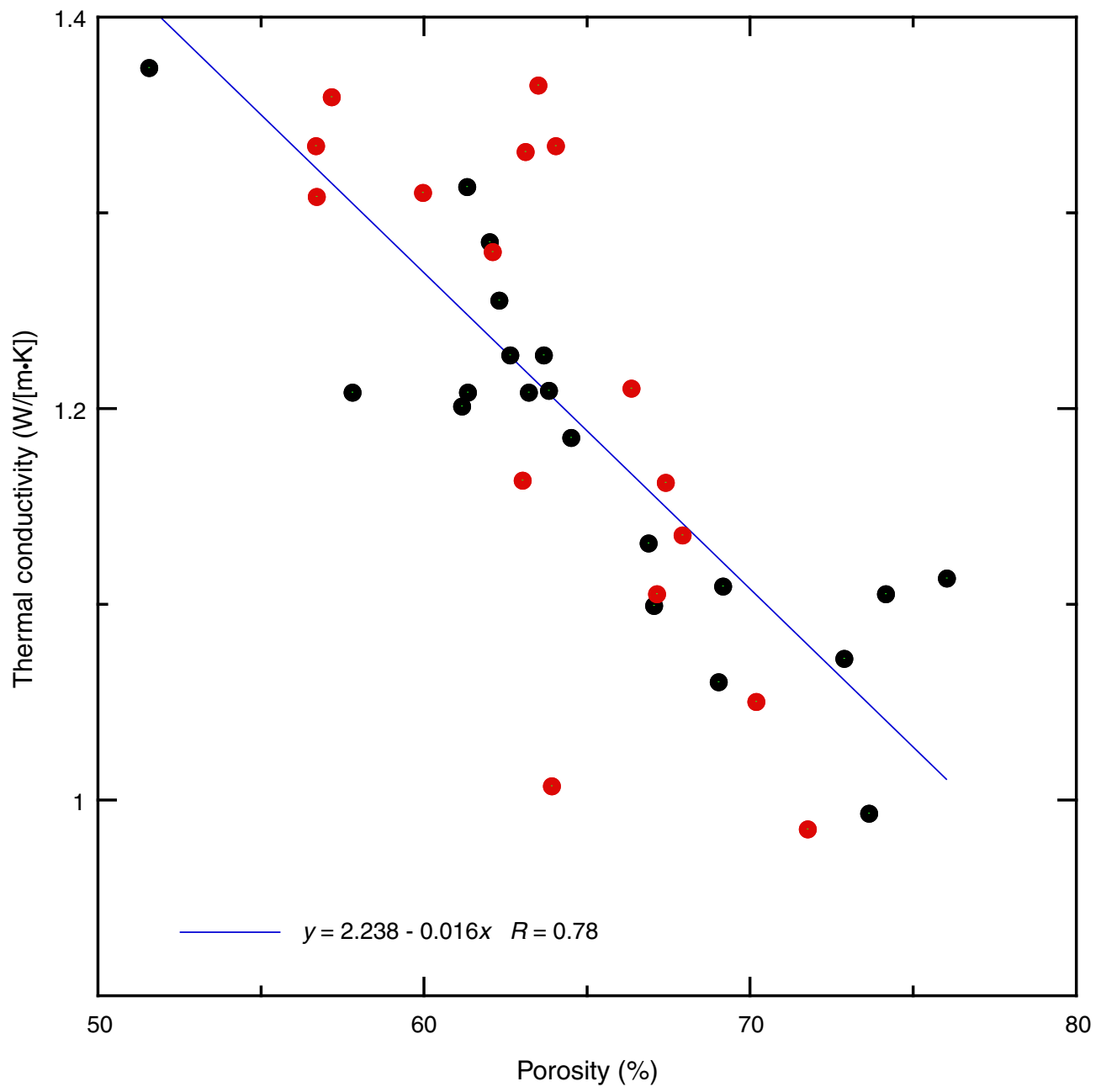


Figure F26. Reflectance spectrophotometry, Holes U1336A (black) and U1336B (red). Data for Hole U1336B are plotted using offsets of 20 for $\mathrm{L}^{*}$ (luminance), 5 for $\mathrm{a}^{*}$ (blue-yellow), and 5 for $\mathrm{b}^{*}$ (green-red).

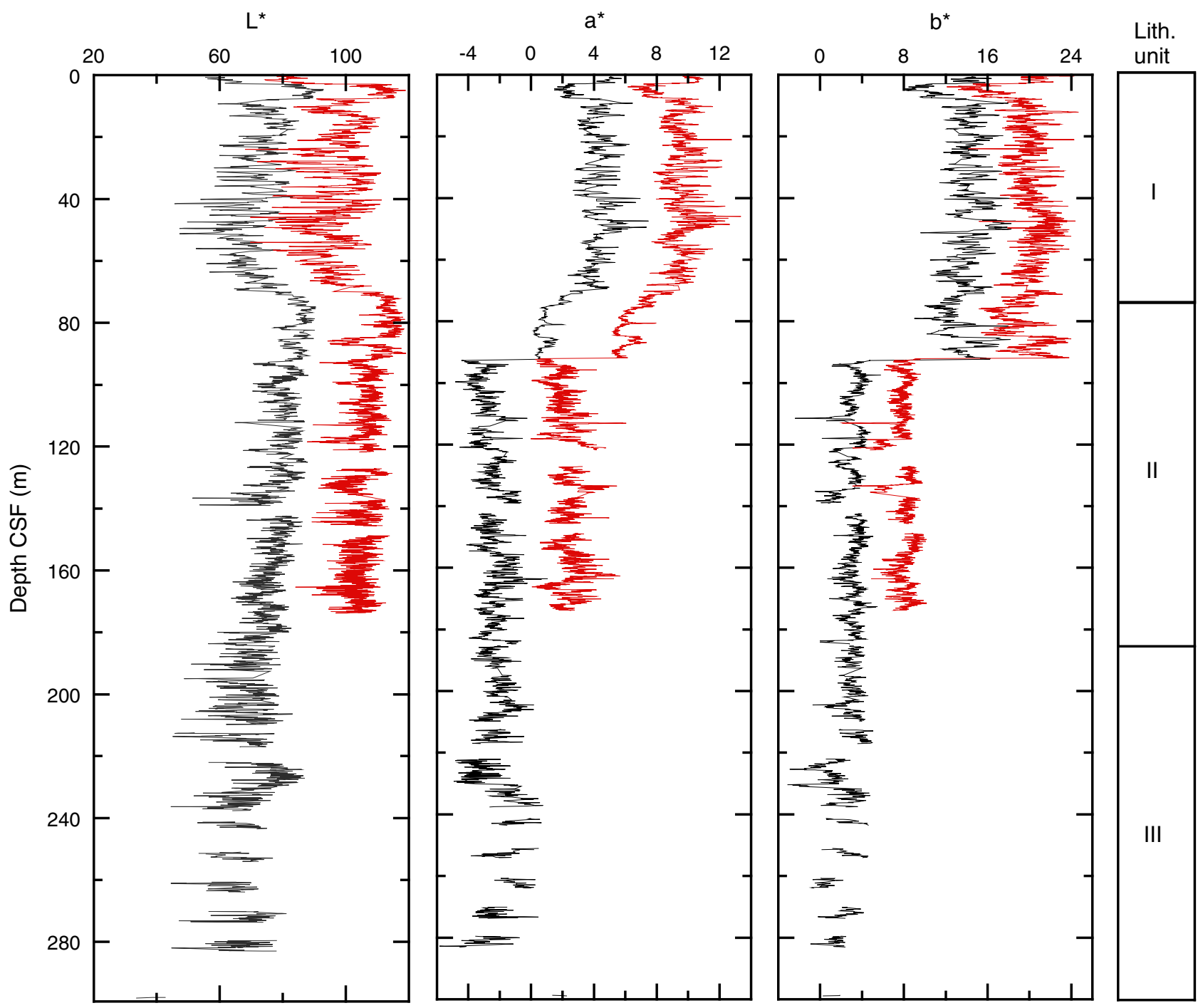


Figure F27. Magnetic susceptibility data, Holes U1336A (red) and U1336B (blue). Data are offset by a constant 10 SI units. Upper panels are the Site U1338 splices for the intervals. A. 0-50 m CCSF-A. (Continued on next three pages.)
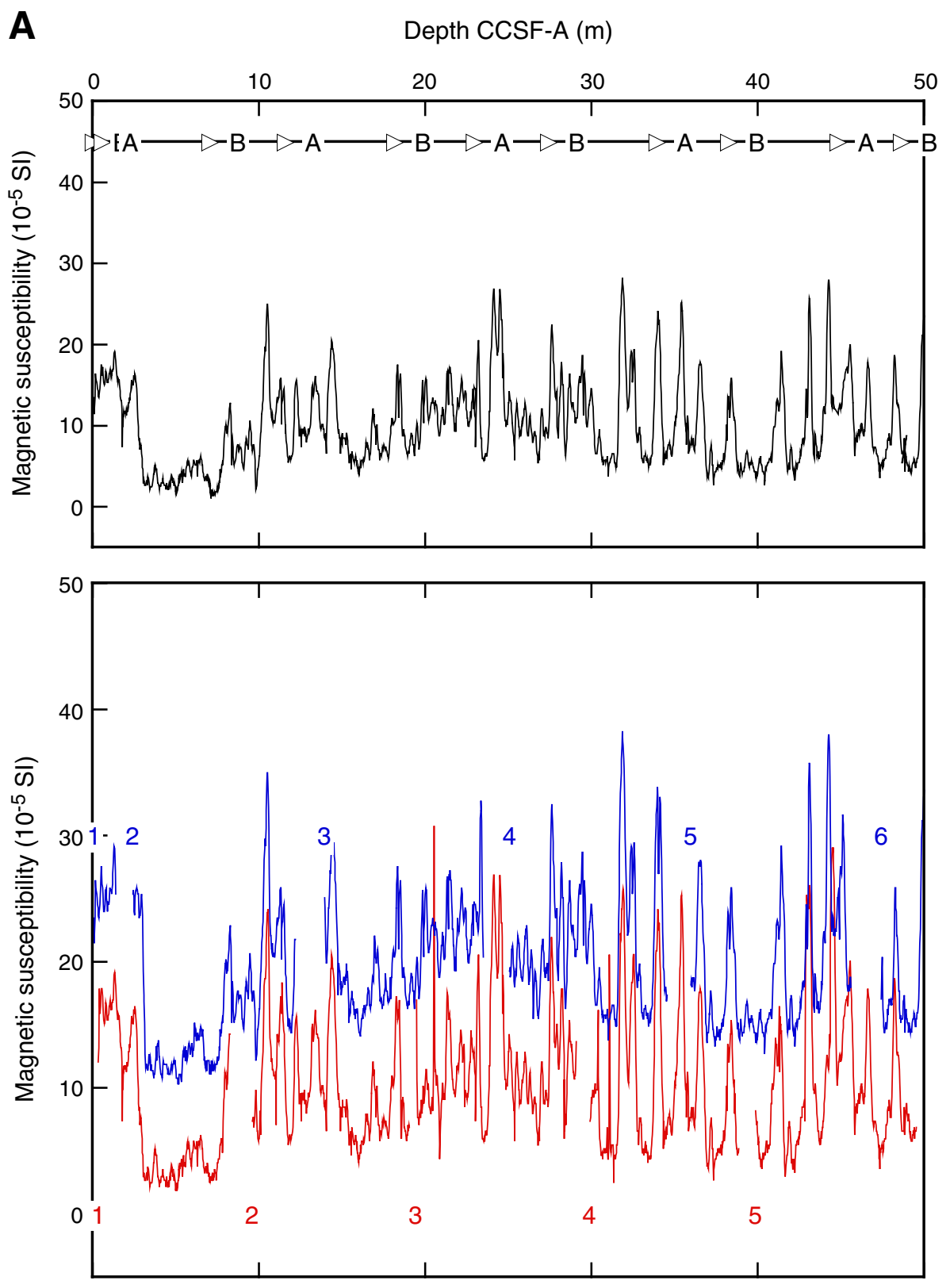
Figure F27 (continued). B. 50-100 m CCSF-A. (Continued on next page.)
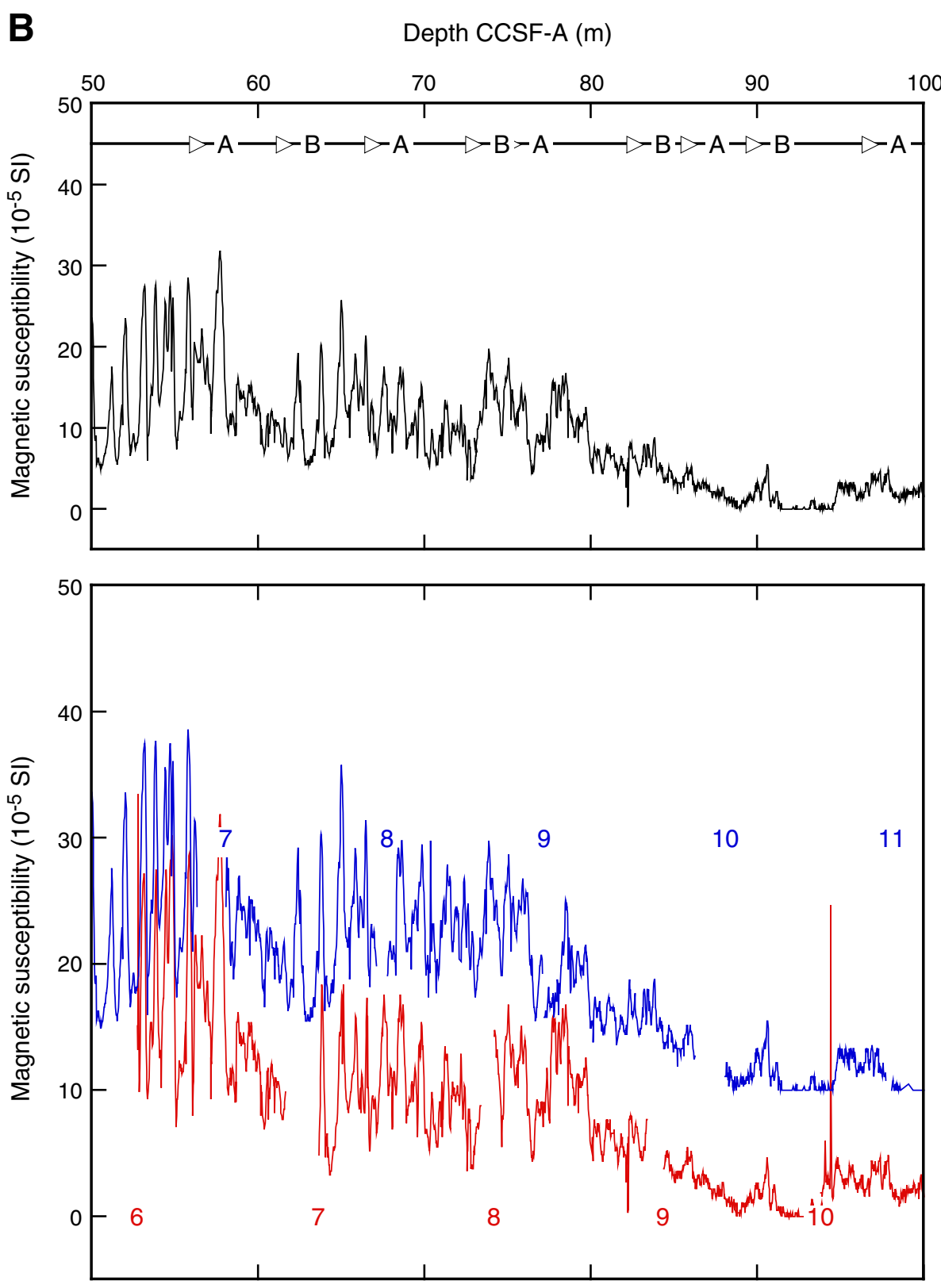
Figure F27 (continued). C. 100-150 m CCSF-A. (Continued on next page.)
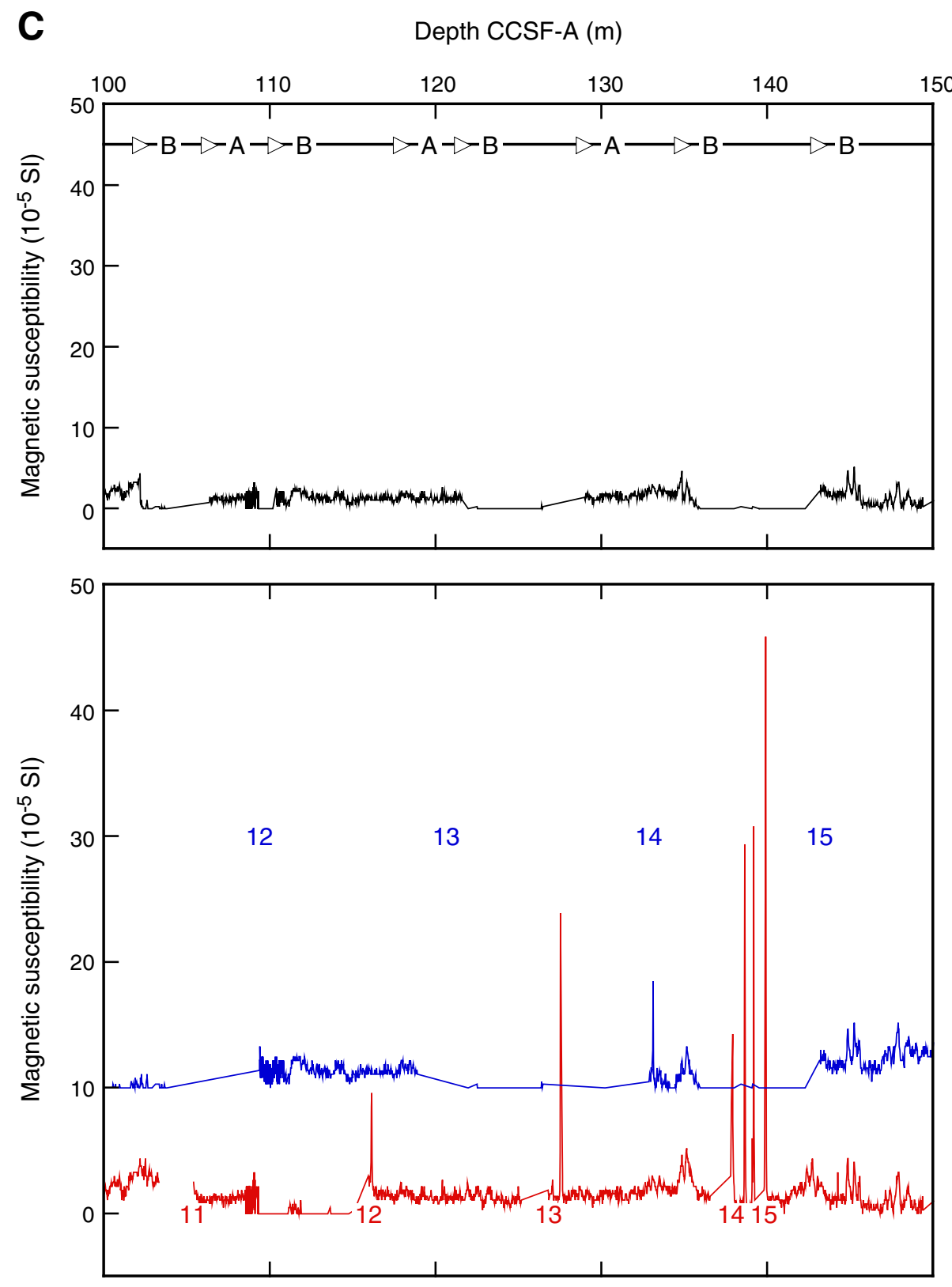
Figure F27 (continued). D. 150-200 m CCSF-A.
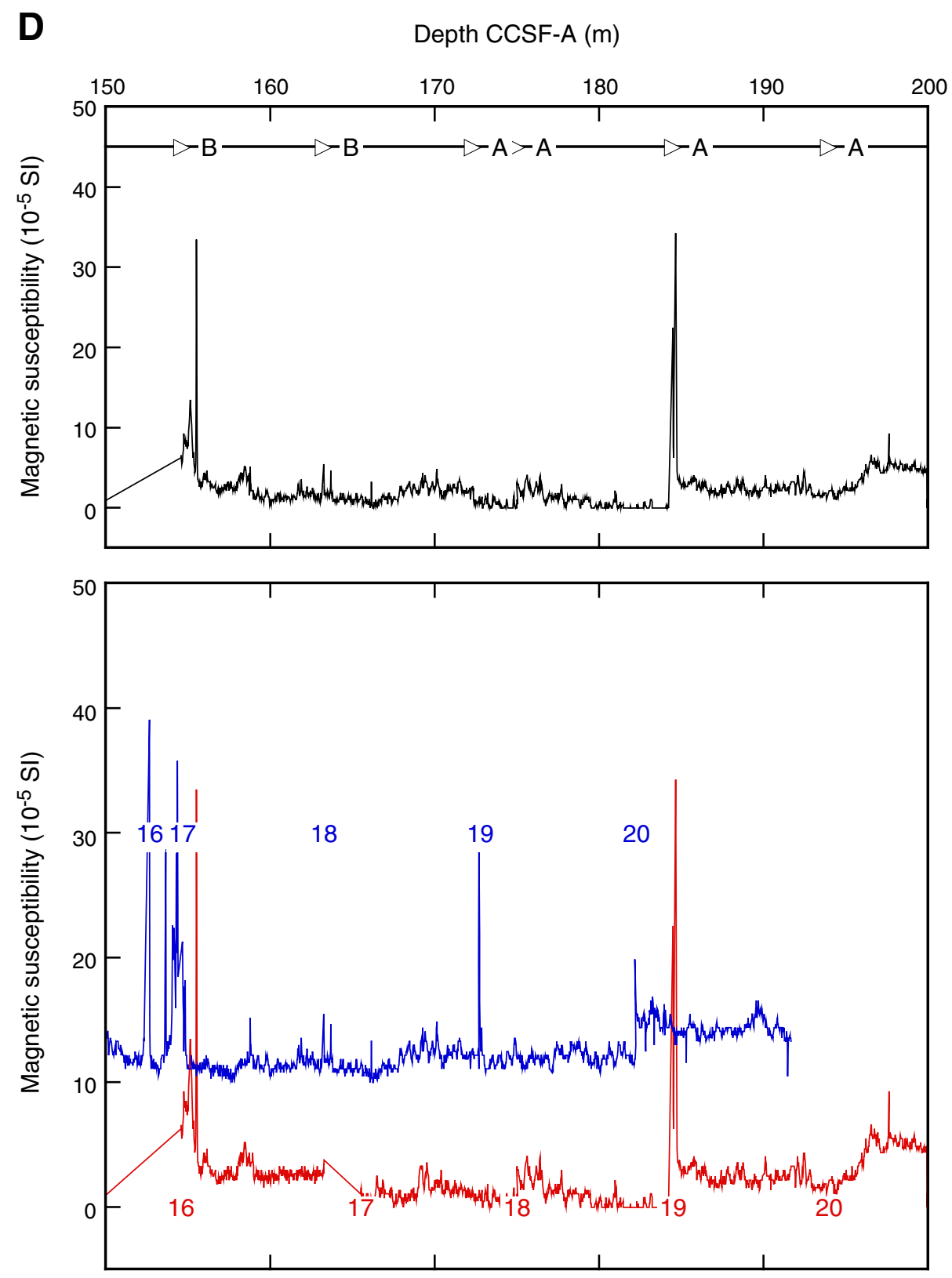
Figure F28. Gamma ray attenuation density data, Holes U1336A (red) and U1336B (blue). Data are offset by a constant $0.5 \mathrm{~g} / \mathrm{cm}^{3}$. Upper panels are the Site U1338 splices for the intervals. A. 0-50 m CCSF-A. (Continued on next three pages.)

A

Depth CCSF-A (m)
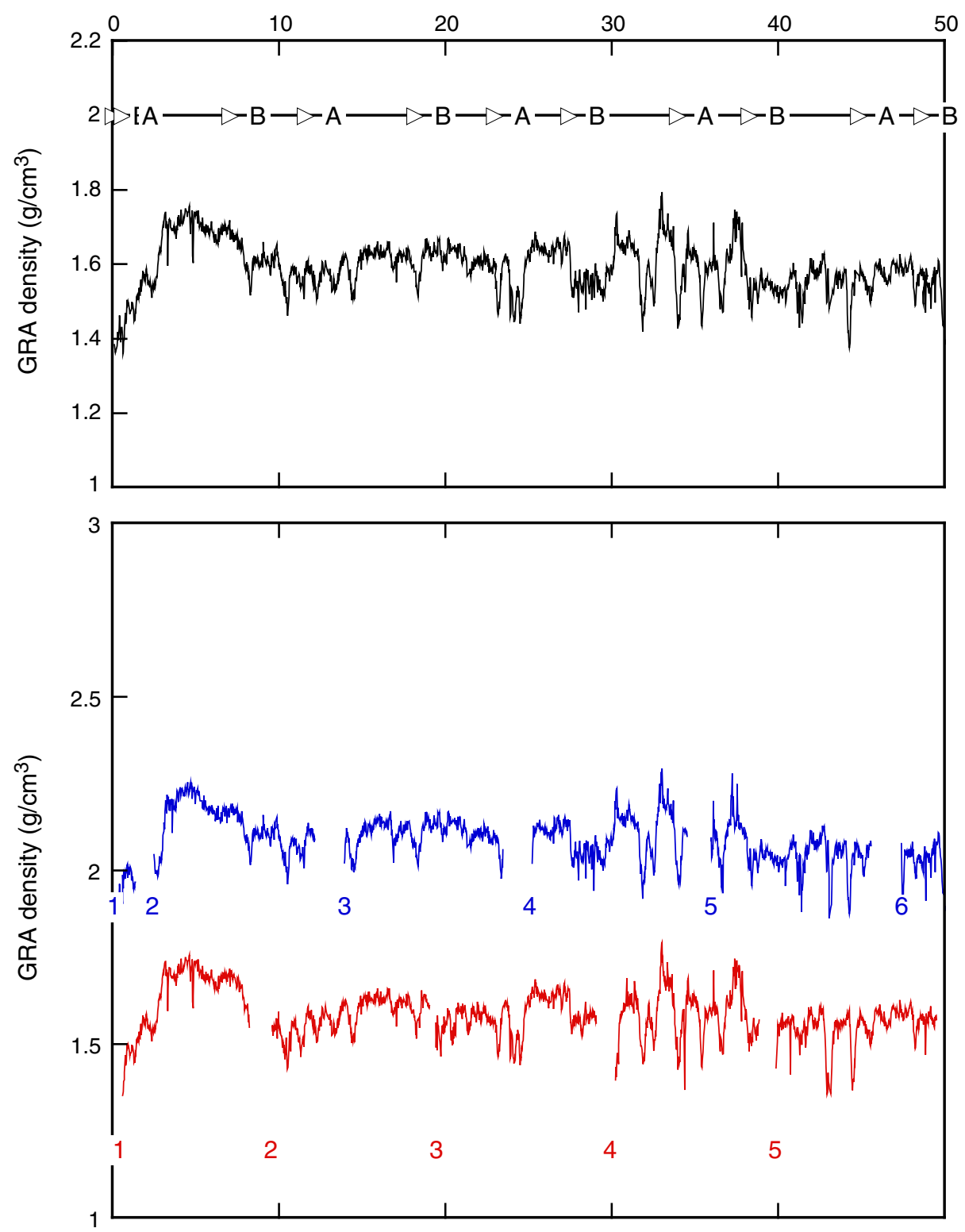
Figure F28 (continued). B. 50-100 m CCSF-A. (Continued on next page.)
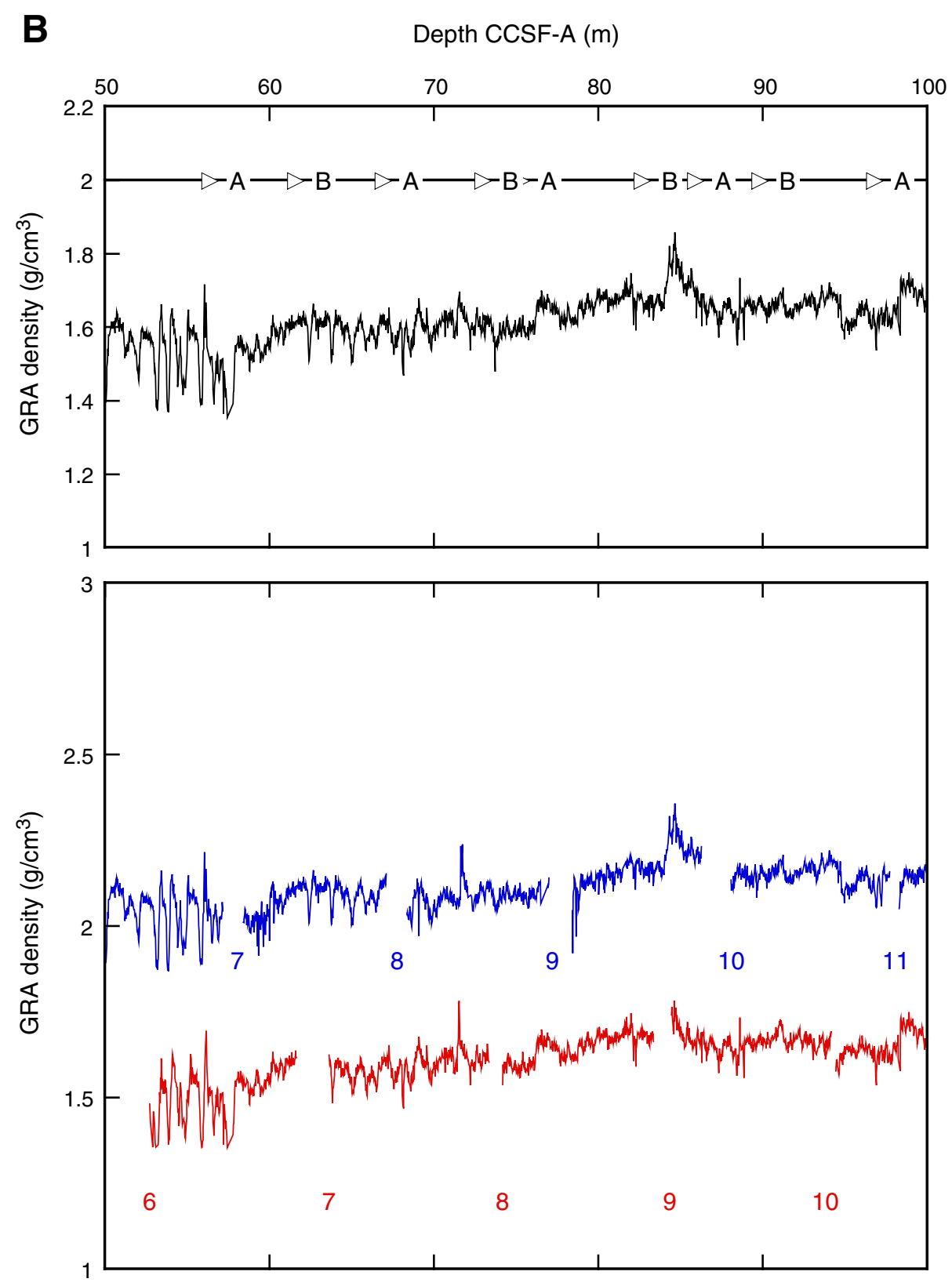
Figure F28 (continued). C. 100-150 m CCSF-A. (Continued on next page.)
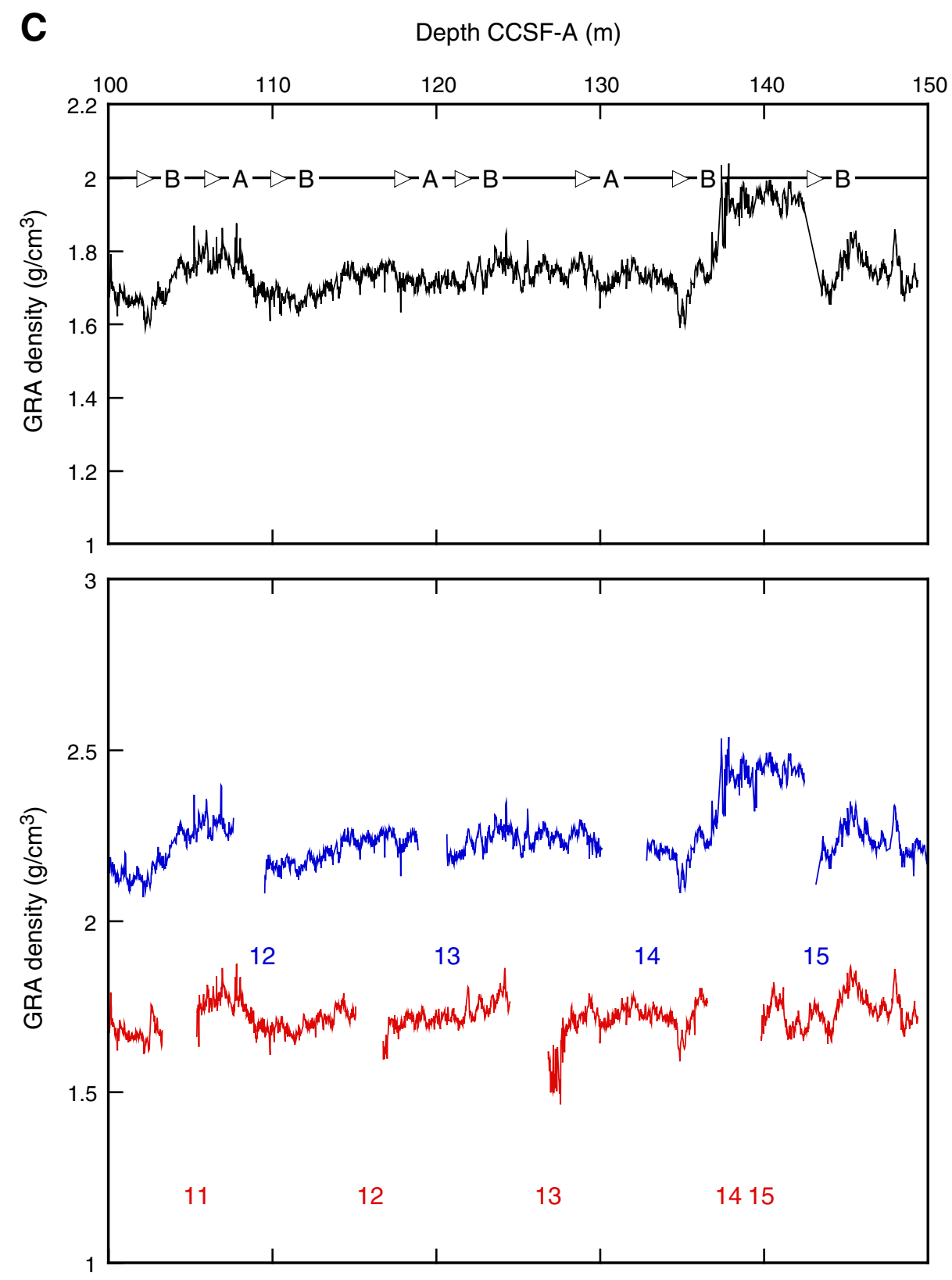
Figure F28 (continued). D. 150-200 m CCSF-A.
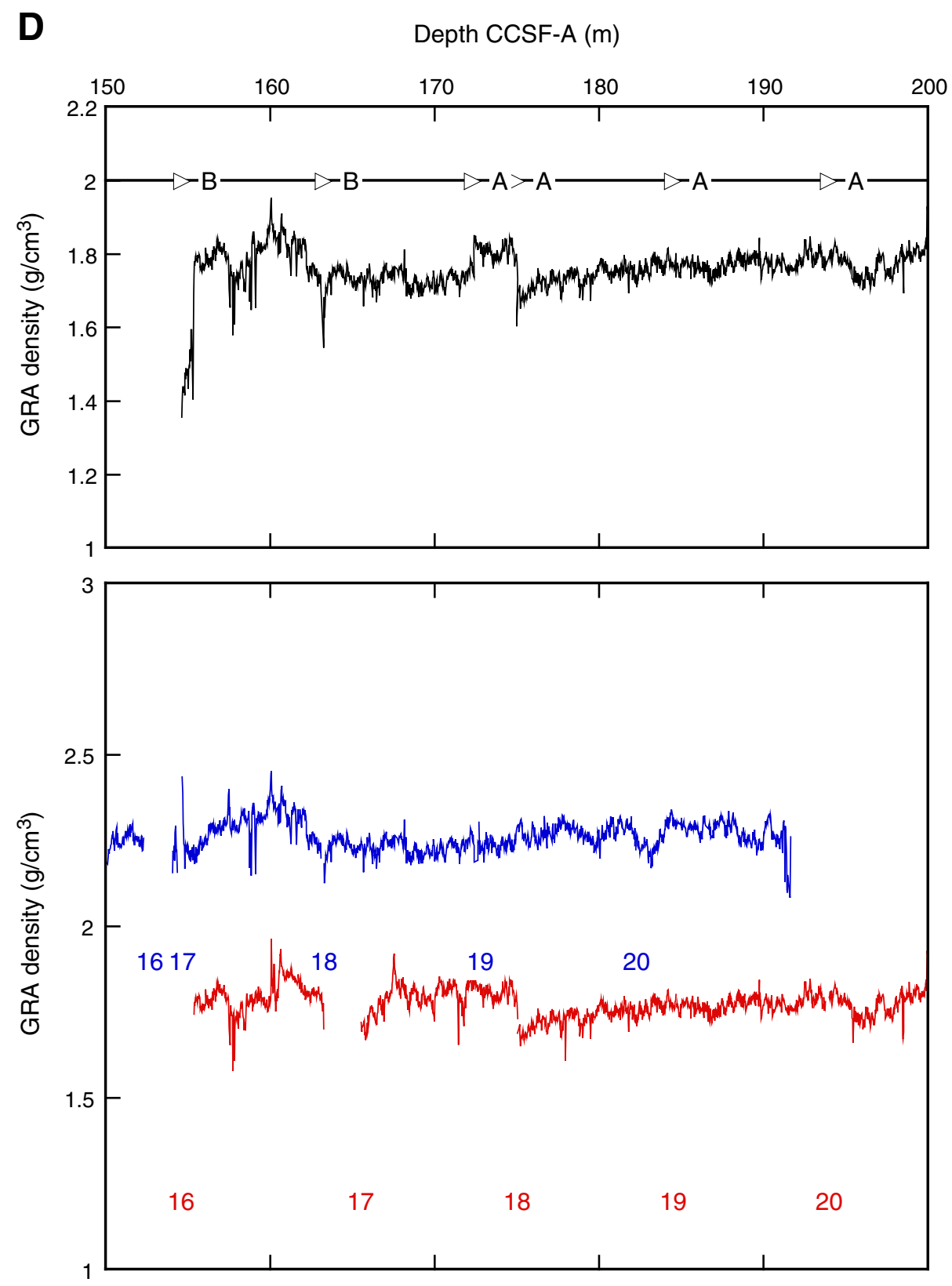
Figure F29. Core images, Holes U1336A and U1336B. Yellow line $=$ top of deepest splice, black bars $=$ disturbed intervals, green lines $=$ floating ties or correlations (see text). Uninterrupted composite section ends at the top of disturbed section in Core 321-U1336B-14H. The most continuous splice appends Core 321-U1336A-15H at this point. Splice continues by appending Cores 320-U1336B-15H through 18H (blue arrow). Splice moves to Core 320-U1336A-18H and stays within Hole U1336A to total depth. Cores 320-U1336A-15H and 320-U1336B-15H can be correlated to one another, but neither can be tied to the rest of the section either above or below.

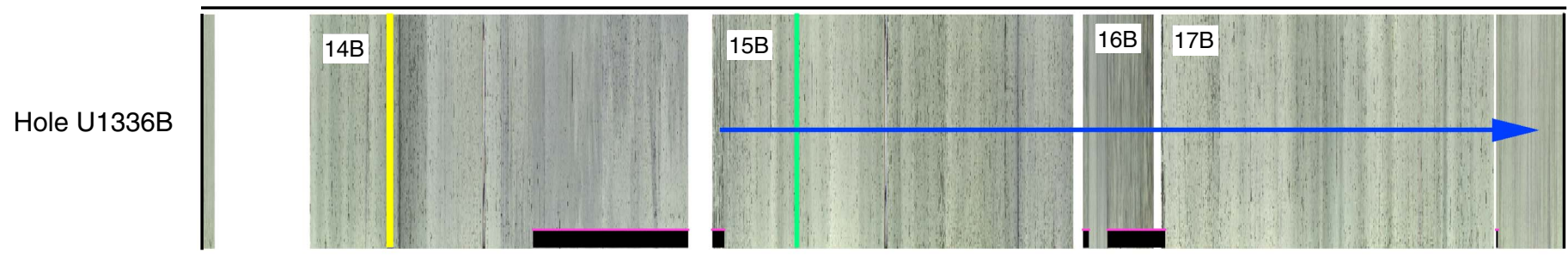

Hole U1336A

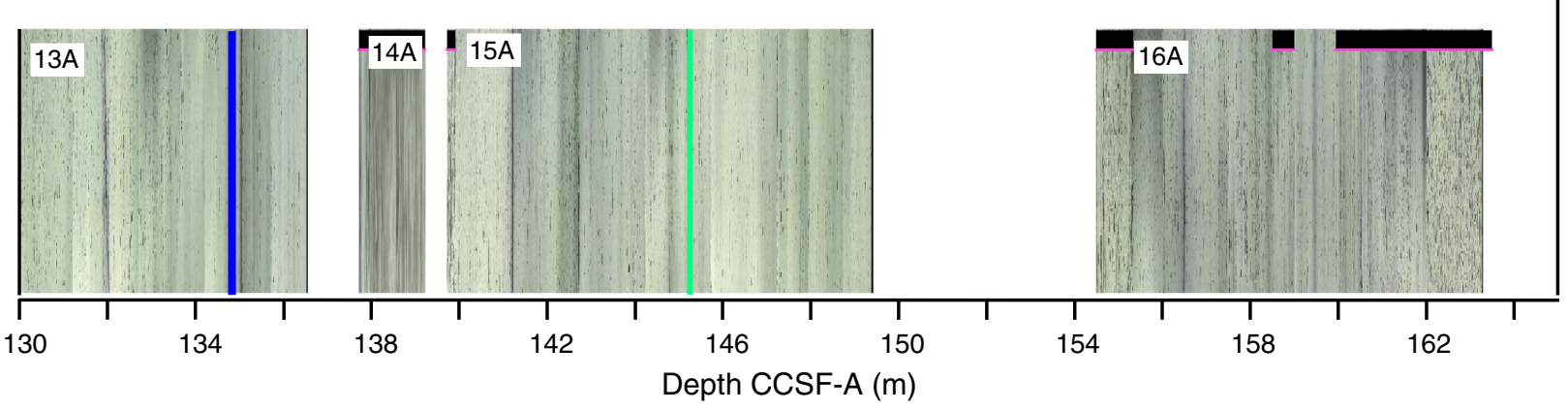

Hole U1336B
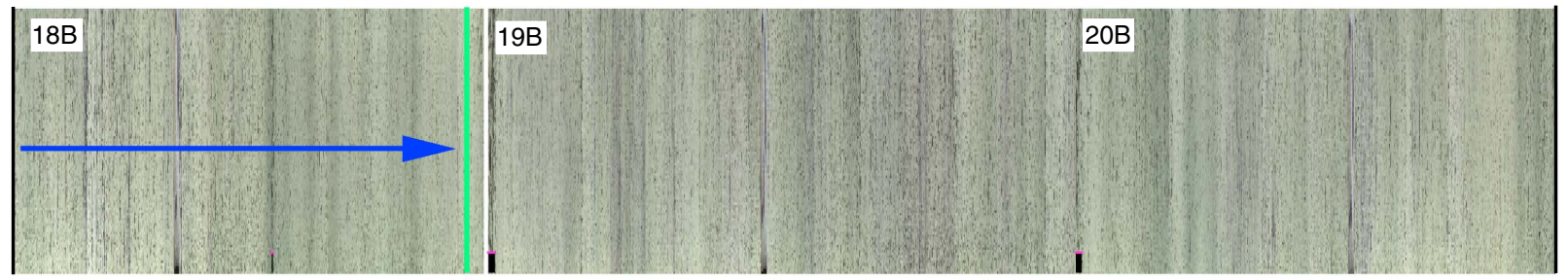

Hole U1336A

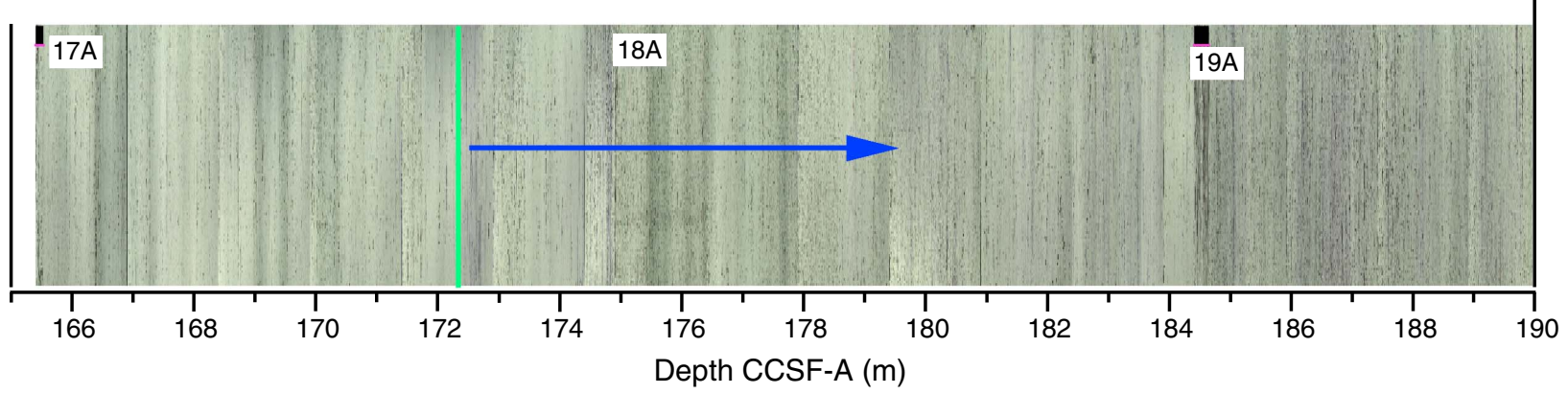


Figure F30. Core depth below seafloor vs. core composite depth below seafloor for tops of cores, Site U1336. Growth factor is slope of the regression line. On average, the core composite depth below seafloor of the spliced section is $13 \%$ greater than the core depth below seafloor.

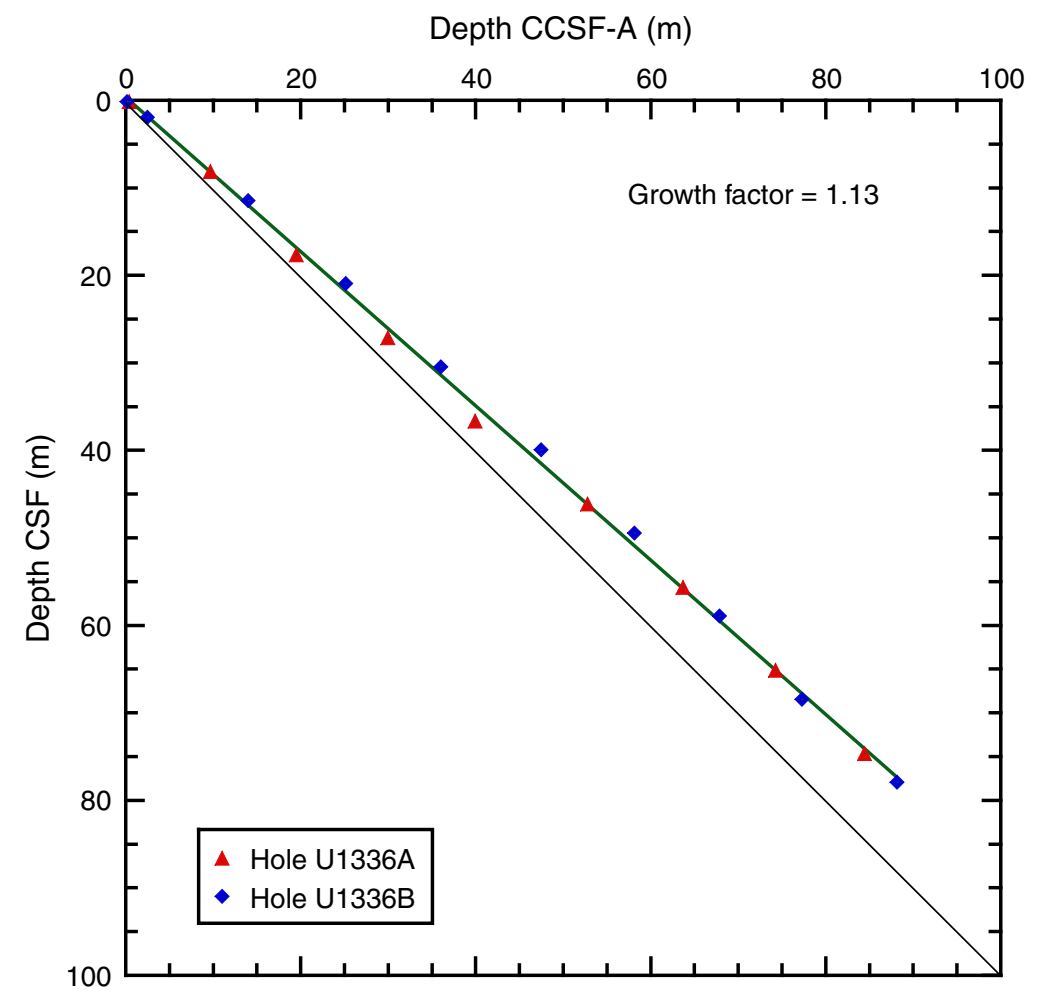


Table T1. Coring summary, Site U1336. (See table notes.) (Continued on next page.)

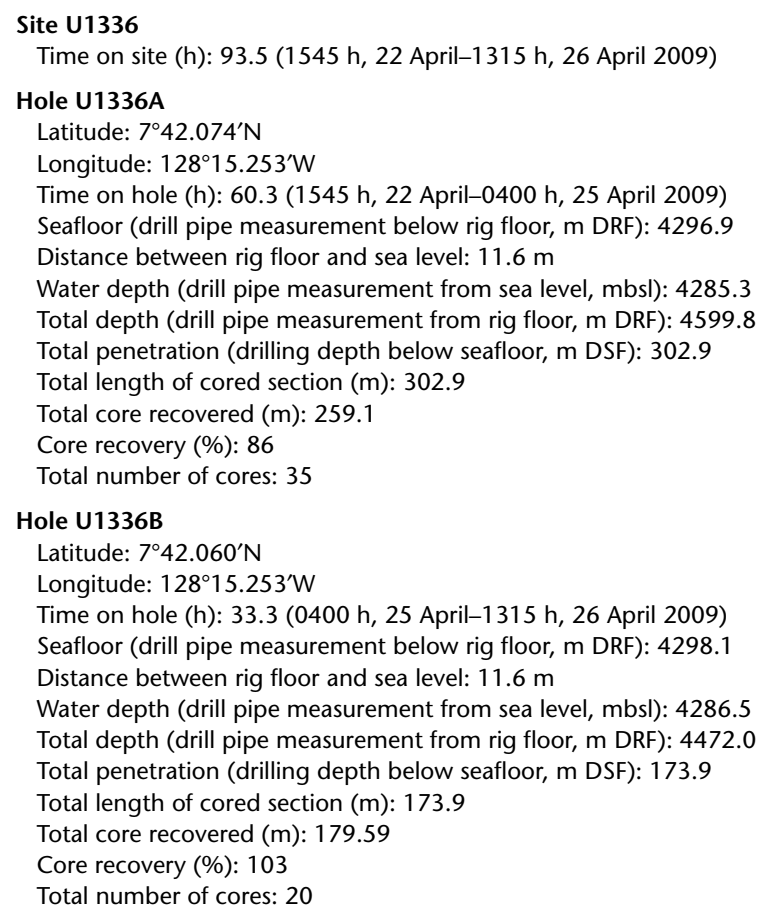

\begin{tabular}{|c|c|c|c|c|c|c|c|c|c|}
\hline \multirow[b]{2}{*}{ Core } & \multirow[b]{2}{*}{$\begin{array}{l}\text { Date } \\
(2009)\end{array}$} & \multirow[b]{2}{*}{$\begin{array}{l}\text { Local time } \\
\text { (h) }\end{array}$} & \multicolumn{2}{|c|}{ Depth DSF $(m)$} & \multirow[b]{2}{*}{$\begin{array}{l}\text { Interval } \\
\text { advanced } \\
(\mathrm{m})\end{array}$} & \multicolumn{2}{|c|}{ Depth CSF (m) } & \multirow[b]{2}{*}{$\begin{array}{l}\text { Length of core } \\
\text { recovered } \\
(\mathrm{m})\end{array}$} & \multirow[b]{2}{*}{$\begin{array}{l}\text { Recovery } \\
(\%)\end{array}$} \\
\hline & & & $\begin{array}{l}\text { Top of } \\
\text { cored } \\
\text { interval }\end{array}$ & $\begin{array}{l}\text { Bottom of } \\
\text { cored } \\
\text { interval }\end{array}$ & & $\begin{array}{l}\text { Top of } \\
\text { cored } \\
\text { interval }\end{array}$ & $\begin{array}{c}\text { Bottom of } \\
\text { cored } \\
\text { interval }\end{array}$ & & \\
\hline \multicolumn{10}{|c|}{ 320-U1336A- } \\
\hline $1 \mathrm{H}$ & $23 \mathrm{Apr}$ & 0200 & 0.0 & 8.0 & 8.0 & 0.00 & 8.24 & 8.24 & 103 \\
\hline $2 \mathrm{H}$ & $23 \mathrm{Apr}$ & 0255 & 8.0 & 17.5 & 9.5 & 8.00 & 17.73 & 9.73 & 102 \\
\hline $3 \mathrm{H}$ & $23 \mathrm{Apr}$ & 0355 & 17.5 & 27.0 & 9.5 & 17.50 & 27.52 & 10.02 & 105 \\
\hline $4 \mathrm{H}$ & $23 \mathrm{Apr}$ & 0455 & 27.0 & 36.5 & 9.5 & 27.00 & 36.25 & 9.25 & 97 \\
\hline $5 \mathrm{H}$ & $23 \mathrm{Apr}$ & 0550 & 36.5 & 46.0 & 9.5 & 36.50 & 46.46 & 9.96 & 105 \\
\hline $6 \mathrm{H}$ & $23 \mathrm{Apr}$ & 0645 & 46.0 & 55.5 & 9.5 & 46.00 & 55.19 & 9.19 & 97 \\
\hline $7 \mathrm{H}$ & $23 \mathrm{Apr}$ & 0750 & 55.5 & 65.0 & 9.5 & 55.50 & 65.61 & 10.11 & 106 \\
\hline $8 \mathrm{H}$ & $23 \mathrm{Apr}$ & 0850 & 65.0 & 74.5 & 9.5 & 65.00 & 74.43 & 9.43 & 99 \\
\hline $9 \mathrm{H}$ & $23 \mathrm{Apr}$ & 0940 & 74.5 & 84.0 & 9.5 & 74.50 & 84.63 & 10.13 & 107 \\
\hline $10 \mathrm{H}$ & $23 \mathrm{Apr}$ & 1040 & 84.0 & 93.5 & 9.5 & 84.00 & 93.83 & 9.83 & 103 \\
\hline $11 \mathrm{H}$ & $23 \mathrm{Apr}$ & 1135 & 93.5 & 103.0 & 9.5 & 93.50 & 103.53 & 10.03 & 106 \\
\hline $12 \mathrm{H}$ & $23 \mathrm{Apr}$ & 1235 & 103.0 & 112.5 & 9.5 & 103.00 & 112.48 & 9.48 & 100 \\
\hline $13 \mathrm{H}$ & $23 \mathrm{Apr}$ & 1330 & 112.5 & 122.0 & 9.5 & 112.50 & 122.63 & 10.13 & 107 \\
\hline $14 \mathrm{H}$ & $23 \mathrm{Apr}$ & 1440 & 122.0 & 123.5 & 1.5 & 122.00 & 123.55 & 1.55 & 103 \\
\hline $15 \mathrm{H}$ & $23 \mathrm{Apr}$ & 1605 & 123.5 & 133.0 & 9.5 & 123.50 & 133.43 & 9.93 & 105 \\
\hline $16 \mathrm{H}$ & $23 \mathrm{Apr}$ & 1705 & 133.0 & 142.0 & 9.0 & 133.00 & 142.04 & 9.04 & 100 \\
\hline $17 \mathrm{H}$ & $23 \mathrm{Apr}$ & 1910 & 142.0 & 151.5 & 9.5 & 142.00 & 151.89 & 9.89 & 104 \\
\hline $18 \mathrm{H}$ & $23 \mathrm{Apr}$ & 2005 & 151.5 & 161.0 & 9.5 & 151.50 & 161.58 & 10.08 & 106 \\
\hline $19 \mathrm{H}$ & $23 \mathrm{Apr}$ & 2125 & 161.0 & 170.5 & 9.5 & 161.00 & 170.65 & 9.65 & 102 \\
\hline $20 \mathrm{H}$ & $23 \mathrm{Apr}$ & 2225 & 170.5 & 180.0 & 9.5 & 170.50 & 180.18 & 9.68 & 102 \\
\hline $21 \mathrm{H}$ & $23 \mathrm{Apr}$ & 2325 & 180.0 & 184.8 & 4.8 & 180.00 & 184.83 & 4.83 & 101 \\
\hline $22 x$ & $24 \mathrm{Apr}$ & 0340 & 184.8 & 194.4 & 9.6 & 184.80 & 192.77 & 7.97 & 83 \\
\hline $23 x$ & $24 \mathrm{Apr}$ & 0535 & 194.4 & 202.4 & 8.0 & 194.40 & 202.20 & 7.80 & 98 \\
\hline $24 X$ & $24 \mathrm{Apr}$ & 0725 & 202.4 & 212.0 & 9.6 & 202.40 & 209.67 & 7.27 & 76 \\
\hline $25 X$ & $24 \mathrm{Apr}$ & 0835 & 212.0 & 221.6 & 9.6 & 212.00 & 216.96 & 4.96 & 52 \\
\hline $26 x$ & $24 \mathrm{Apr}$ & 0955 & 221.6 & 231.2 & 9.6 & 221.60 & 231.00 & 9.40 & 98 \\
\hline $27 x$ & $24 \mathrm{Apr}$ & 1100 & 231.2 & 240.8 & 9.6 & 231.20 & 237.83 & 6.63 & 69 \\
\hline $28 x$ & $24 \mathrm{Apr}$ & 1235 & 240.8 & 250.4 & 9.6 & 240.80 & 243.83 & 3.03 & 32 \\
\hline $29 x$ & $24 \mathrm{Apr}$ & 1355 & 250.4 & 260.0 & 9.6 & 250.40 & 254.57 & 4.17 & 43 \\
\hline $30 x$ & $24 \mathrm{Apr}$ & 1505 & 260.0 & 269.6 & 9.6 & 260.00 & 264.50 & 4.43 & 47 \\
\hline $31 x$ & $24 \mathrm{Apr}$ & 1630 & 269.6 & 279.2 & 9.6 & 269.60 & 274.61 & 5.01 & 52 \\
\hline $32 x$ & $24 \mathrm{Apr}$ & 1800 & 279.2 & 288.8 & 9.6 & 279.20 & 283.34 & 4.14 & 43 \\
\hline $33 x$ & $24 \mathrm{Apr}$ & 1950 & 288.8 & 293.8 & 5.0 & 288.80 & 291.29 & 2.49 & 50 \\
\hline
\end{tabular}


Table T1 (continued).

\begin{tabular}{|c|c|c|c|c|c|c|c|c|c|}
\hline \multirow[b]{2}{*}{ Core } & \multirow[b]{2}{*}{$\begin{array}{c}\text { Date } \\
(2009)\end{array}$} & \multirow[b]{2}{*}{$\begin{array}{l}\text { Local time } \\
\text { (h) }\end{array}$} & \multicolumn{2}{|c|}{ Depth DSF (m) } & \multirow[b]{2}{*}{$\begin{array}{l}\text { Interval } \\
\text { advanced } \\
(\mathrm{m})\end{array}$} & \multicolumn{2}{|c|}{ Depth CSF (m) } & \multirow[b]{2}{*}{$\begin{array}{l}\text { Length of core } \\
\text { recovered } \\
\text { (m) }\end{array}$} & \multirow[b]{2}{*}{$\begin{array}{l}\text { Recovery } \\
\text { (\%) }\end{array}$} \\
\hline & & & $\begin{array}{l}\text { Top of } \\
\text { cored } \\
\text { interval }\end{array}$ & $\begin{array}{l}\text { Bottom of } \\
\text { cored } \\
\text { interval }\end{array}$ & & $\begin{array}{l}\text { Top of } \\
\text { cored } \\
\text { interval }\end{array}$ & $\begin{array}{c}\text { Bottom of } \\
\text { cored } \\
\text { interval }\end{array}$ & & \\
\hline $34 X$ & $24 \mathrm{Apr}$ & 2255 & 293.8 & 298.3 & 4.5 & 293.80 & 294.12 & 0.32 & 7 \\
\hline \multirow[t]{3}{*}{$35 x$} & $25 \mathrm{Apr}$ & 0200 & 298.3 & 302.9 & 4.6 & 298.30 & 299.62 & 1.32 & 29 \\
\hline & & & & Cored totals: & 302.9 & & & 259.12 & 86 \\
\hline & & & Total in & terval cored: & 302.9 & & & & \\
\hline \multicolumn{10}{|c|}{ 320-U1336B- } \\
\hline $1 \mathrm{H}$ & $25 \mathrm{Apr}$ & 0610 & 0.0 & 1.8 & 1.8 & 0.00 & 1.73 & 1.73 & 96 \\
\hline $2 \mathrm{H}$ & $25 \mathrm{Apr}$ & 0710 & 1.8 & 11.3 & 9.5 & 1.80 & 11.88 & 10.08 & 106 \\
\hline $3 \mathrm{H}$ & $25 \mathrm{Apr}$ & 0815 & 11.3 & 20.8 & 9.5 & 11.30 & 21.16 & 9.86 & 104 \\
\hline $4 \mathrm{H}$ & $25 \mathrm{Apr}$ & 0910 & 20.8 & 30.3 & 9.5 & 20.80 & 30.57 & 9.77 & 103 \\
\hline $5 \mathrm{H}$ & $25 \mathrm{Apr}$ & 1010 & 30.3 & 39.8 & 9.5 & 30.30 & 40.30 & 10.00 & 105 \\
\hline $6 \mathrm{H}$ & $25 \mathrm{Apr}$ & 1110 & 39.8 & 49.3 & 9.5 & 39.80 & 49.90 & 10.10 & 106 \\
\hline $7 \mathrm{H}$ & $25 \mathrm{Apr}$ & 1205 & 49.3 & 58.8 & 9.5 & 49.30 & 58.68 & 9.38 & 99 \\
\hline $8 \mathrm{H}$ & $25 \mathrm{Apr}$ & 1300 & 58.8 & 68.3 & 9.5 & 58.80 & 68.50 & 9.70 & 102 \\
\hline $9 \mathrm{H}$ & $25 \mathrm{Apr}$ & 1355 & 68.3 & 77.8 & 9.5 & 68.30 & 77.77 & 9.47 & 100 \\
\hline $10 \mathrm{H}$ & $25 \mathrm{Apr}$ & 1450 & 77.8 & 87.3 & 9.5 & 77.80 & 87.80 & 10.00 & 105 \\
\hline $11 \mathrm{H}$ & $25 \mathrm{Apr}$ & 1550 & 87.3 & 96.8 & 9.5 & 87.30 & 97.25 & 9.95 & 105 \\
\hline $12 \mathrm{H}$ & $25 \mathrm{Apr}$ & 1645 & 96.8 & 106.3 & 9.5 & 96.80 & 106.60 & 9.80 & 103 \\
\hline $13 \mathrm{H}$ & $25 \mathrm{Apr}$ & 1740 & 106.3 & 115.8 & 9.5 & 106.30 & 116.41 & 10.11 & 106 \\
\hline $14 \mathrm{H}$ & $25 \mathrm{Apr}$ & 1845 & 115.8 & 125.3 & 9.5 & 115.80 & 125.89 & 10.09 & 106 \\
\hline $15 \mathrm{H}$ & $25 \mathrm{Apr}$ & 1940 & 125.3 & 134.8 & 9.5 & 125.30 & 134.83 & 9.53 & 100 \\
\hline $16 \mathrm{H}$ & $25 \mathrm{Apr}$ & 2045 & 134.8 & 136.8 & 2.0 & 134.80 & 136.86 & 2.06 & 103 \\
\hline $17 \mathrm{H}$ & $25 \mathrm{Apr}$ & 2150 & 136.8 & 145.4 & 8.6 & 136.80 & 145.66 & 8.86 & 103 \\
\hline $18 \mathrm{H}$ & $25 \mathrm{Apr}$ & 2315 & 145.4 & 154.9 & 9.5 & 145.40 & 155.05 & 9.65 & 102 \\
\hline $19 \mathrm{H}$ & $26 \mathrm{Apr}$ & 0020 & 154.9 & 164.4 & 9.5 & 154.90 & 164.74 & 9.84 & 104 \\
\hline \multirow[t]{3}{*}{$20 \mathrm{H}$} & $26 \mathrm{Apr}$ & 0150 & 164.4 & 173.9 & 9.5 & 164.40 & 174.01 & 9.61 & 101 \\
\hline & & & & Cored totals: & 173.9 & & & 179.59 & 103 \\
\hline & & & \multicolumn{2}{|c|}{ Total interval cored: } & 173.9 & & & & \\
\hline
\end{tabular}

Notes: $\mathrm{DRF}=$ drilling depth below rig floor, DSF $=$ drilling depth below seafloor, $\mathrm{CSF}=$ core depth below seafloor. $\mathrm{H}=\mathrm{APC}$ core, $\mathrm{X}=\mathrm{XCB}$ core. Local time $=$ UTC $-10 \mathrm{~h}$.

Table T2. Lithologic unit boundaries, Site U1336. (See table notes.)

\begin{tabular}{|c|c|c|c|c|c|}
\hline Unit & Lithologic summary & $\begin{array}{l}\text { Core, section, } \\
\text { interval }(\mathrm{cm})\end{array}$ & $\begin{array}{l}\text { Depth } \\
\text { CSF (m) }\end{array}$ & $\begin{array}{l}\text { Core, section, } \\
\text { interval }(\mathrm{cm})\end{array}$ & $\begin{array}{l}\text { Depth } \\
\operatorname{CSF}(\mathrm{m})\end{array}$ \\
\hline I & $\begin{array}{l}\text { Nannofossil ooze with minor but varying } \\
\text { amounts of clay, radiolarians, and } \\
\text { foraminifers; two thin intervals of diatom } \\
\text { nannofossil ooze. }\end{array}$ & $\begin{array}{l}\text { 320-U1336A- } \\
8 \mathrm{H}-7,5\end{array}$ & 73.05 & $\begin{array}{c}320-U 1336 \mathrm{~B}- \\
9 \mathrm{H}-5,84\end{array}$ & 75.14 \\
\hline II & $\begin{array}{l}\text { Nannofossil ooze, minor chert near base, } \\
\text { vivid redox coloring from pale yellow to } \\
\text { greenish gray, very low magnetic } \\
\text { susceptibility values. }\end{array}$ & $22 \mathrm{H}-4,20$ & 189.5 & $20 \mathrm{H}-7,58$ & $173.98^{\dagger}$ \\
\hline$\| I^{*}$ & Nannofossil chalk and chert. & $35 \mathrm{X}-\mathrm{CC}, 38$ & 299.6 & & \\
\hline
\end{tabular}

Notes: Intervals/depths are given for basal boundary of each unit. ${ }^{*}=$ unit extends through at least given interval and depth, but boundary was not cored, $\dagger=$ end of Hole U1336B. 
Table T3. Calcareous nannofossil datums, Site U1336. (See table note.)

\begin{tabular}{|c|c|c|c|c|c|c|c|}
\hline \multicolumn{2}{|c|}{ Core, section, interval $(\mathrm{cm})$} & \multirow[b]{2}{*}{ Marker species } & \multirow{2}{*}{$\begin{array}{l}\text { Age } \\
(\mathrm{Ma})\end{array}$} & \multicolumn{4}{|c|}{ Depth CSF (m) } \\
\hline Top & Bottom & & & Top & Bottom & Midpoint & \pm \\
\hline \multirow{2}{*}{$\begin{array}{c}\text { 320-U1336A- } \\
-\end{array}$} & 320-U1336A- & & & & & & \\
\hline & $1 \mathrm{H}-1,110$ & T Coronocyclus nitescens & 12.12 & & 1.10 & 1.10 & \\
\hline- & $1 \mathrm{H}-1,110$ & T Calcidiscus premacintyrei & 12.45 & & 1.10 & 1.10 & \\
\hline $2 \mathrm{H}-4,80$ & $2 \mathrm{H}-6,80$ & Tc Cyclicargolithus floridanus & 13.33 & 13.30 & 16.30 & 14.80 & 1.50 \\
\hline $2 \mathrm{H}-\mathrm{CC}$ & $3 \mathrm{H}-2,90$ & T Sphenolithus heteromorphus & 13.53 & 17.68 & 19.90 & 18.79 & 1.11 \\
\hline $4 \mathrm{H}-2,90$ & $4 \mathrm{H}-4,90$ & Tc Discoaster deflandrei & 15.66 & 29.40 & 32.40 & 30.90 & 1.50 \\
\hline $5 \mathrm{H}-4,64$ & $5 \mathrm{H}-6,35$ & B Discoaster petaliformis & 15.70 & 41.64 & 44.35 & 43.00 & 1.36 \\
\hline $7 \mathrm{H}-2,50$ & $7 \mathrm{H}-3,52$ & Bc Sphenolithus heteromorphus & 17.71 & 57.50 & 59.02 & 58.26 & 0.76 \\
\hline $7 \mathrm{H}-2,50$ & $7 \mathrm{H}-3,52$ & Tc Sphenolithus belemnos & 17.95 & 57.50 & 59.02 & 58.26 & 0.76 \\
\hline $7 \mathrm{H}-2,50$ & $7 \mathrm{H}-3,52$ & T Triquetrorhabdulus carinatus & 18.28 & 57.50 & 59.02 & 58.26 & 0.76 \\
\hline $8 \mathrm{H}-\mathrm{CC}$ & $9 \mathrm{H}-1,55$ & B Sphenolithus belemnos & 19.03 & 74.38 & 75.05 & 74.72 & 0.34 \\
\hline $13 \mathrm{H}-6,60$ & $13 \mathrm{H}-\mathrm{CC}$ & Tc Triquetrorhabdulus carinatus & 22.09 & 120.60 & 122.58 & 121.59 & 0.99 \\
\hline \multirow[t]{2}{*}{$15 \mathrm{H}-\mathrm{CC}$} & $16 \mathrm{H}-2,90$ & B Sphenolithus disbelemnos & 22.80 & 133.38 & 135.40 & 134.39 & 1.01 \\
\hline & & Oligocene/Miocene boundary & & & & & \\
\hline $17 \mathrm{H}-2,90$ & $17 \mathrm{H}-4,90$ & T Sphenolithus delphix & 23.1 & 144.40 & 147.40 & 145.90 & 1.50 \\
\hline $17 \mathrm{H}-6,90$ & $17 \mathrm{H}-\mathrm{CC}$ & B Sphenolithus delphix & 23.2 & 150.40 & 151.84 & 151.12 & 0.72 \\
\hline $20 \mathrm{H}-5,100$ & $20 \mathrm{H}-\mathrm{CC}$ & T Sphenolithus ciperoensis & 24.4 & 177.50 & 180.13 & 178.82 & 1.32 \\
\hline $20 \mathrm{H}-5,100$ & $20 \mathrm{H}-\mathrm{CC}$ & $\mathrm{X} T$. longus/T. carinatus & 24.7 & 177.50 & 180.13 & 178.82 & 1.32 \\
\hline $19 \mathrm{H}-5,70$ & $19 \mathrm{H}-6,70$ & Tc Cyclicargolithus abisectus & 24.7 & 167.70 & 169.20 & 168.45 & 0.75 \\
\hline $24 X-1,112$ & $24 X-3,73$ & T Sphenolithus distentus & 26.8 & 203.52 & 206.13 & 204.83 & 1.30 \\
\hline $24 X-3,112$ & $24 X-5,53$ & T Sphenolithus predistentus & 26.9 & 206.13 & 208.93 & 207.53 & 1.40 \\
\hline $24 X-5,53$ & $24 \mathrm{X}-\mathrm{CC}$ & B Sphenolithus ciperoensis & 27.1 & 208.93 & 209.62 & 209.28 & 0.34 \\
\hline $29 X-3,40$ & $29 \mathrm{X}-\mathrm{CC}$ & B Sphenolithus distentus & 30.0 & 253.80 & 254.52 & 254.16 & 0.36 \\
\hline $34 \mathrm{X}-\mathrm{CC}$ & $35 X-1,34$ & T Reticulofenestra umbilicus & 32.0 & 294.07 & 298.64 & 296.36 & 2.29 \\
\hline \multicolumn{8}{|c|}{ 321-U1336B- 321-U1336B- } \\
\hline $1 \mathrm{H}-\mathrm{CC}$ & $2 \mathrm{H}-\mathrm{CC}$ & T Coronocyclus nitescens & 12.12 & 1.68 & 11.88 & 6.78 & 5.10 \\
\hline $1 \mathrm{H}-\mathrm{CC}$ & $2 \mathrm{H}-\mathrm{CC}$ & T Calcidiscus premacintyrei & 12.45 & 1.68 & 11.88 & 6.78 & 5.10 \\
\hline $2 \mathrm{H}-\mathrm{CC}$ & $3 \mathrm{H}-\mathrm{CC}$ & Tc Cyclicargolithus floridanus & 13.33 & 11.63 & 21.16 & 16.40 & 4.77 \\
\hline $2 \mathrm{H}-\mathrm{CC}$ & $3 \mathrm{H}-\mathrm{CC}$ & T Sphenolithus heteromorphus & 13.53 & 11.63 & 21.16 & 16.40 & 4.77 \\
\hline $4 \mathrm{H}-\mathrm{CC}$ & $5 \mathrm{H}-\mathrm{CC}$ & Tc Discoaster deflandrei & 15.66 & 30.54 & 40.30 & 35.42 & 4.88 \\
\hline $6 \mathrm{H}-\mathrm{CC}$ & 7H-CC & Bc Sphenolithus heteromorphus & 17.71 & 49.87 & 58.68 & 54.28 & 4.41 \\
\hline $6 \mathrm{H}-\mathrm{CC}$ & 7H-CC & T Sphenolithus belemnos & 17.95 & 49.87 & 58.68 & 54.28 & 4.41 \\
\hline $6 \mathrm{H}-\mathrm{CC}$ & 7H-CC & T Triquetrorhabdulus carinatus & 18.28 & 49.87 & 58.68 & 54.28 & 4.41 \\
\hline $9 \mathrm{H}-\mathrm{CC}$ & $10 \mathrm{H}-\mathrm{CC}$ & B Sphenolithus belemnos & 19.03 & 77.72 & 87.80 & 82.76 & 5.04 \\
\hline $14 \mathrm{H}-1,149$ & $14 \mathrm{H}-2,149$ & Tc Triquetrorhabdulus carinatus & 22.09 & 117.29 & 118.79 & 118.04 & 0.75 \\
\hline \multirow[t]{2}{*}{$15 \mathrm{H}-1,10$} & $15 \mathrm{H}-2,10$ & B Sphenolithus disbelemnos & 22.80 & 125.40 & 126.90 & 126.15 & 0.75 \\
\hline & & Oligocene/Miocene boundary & & & & & \\
\hline $16 \mathrm{H}-\mathrm{CC}$ & $17 \mathrm{H}-1,150$ & lithu & 23.1 & 136.81 & 138.30 & 137.56 & 0.75 \\
\hline $17 \mathrm{H}-3,149$ & $17 \mathrm{H}-4,148$ & B Sphenolithus delphix & 23.2 & 141.29 & 142.78 & 142.04 & 0.75 \\
\hline
\end{tabular}

Note: $\mathrm{T}=$ top, $\mathrm{Tc}=$ top common, $\mathrm{B}=$ bottom, $\mathrm{BC}=$ bottom common, $\mathrm{X}=$ abundance crossover. 
Table T4. Radiolarian datums, Site U1336. (See table notes.)

\begin{tabular}{|c|c|c|c|c|c|c|c|c|c|}
\hline \multirow{2}{*}{$\begin{array}{c}\text { Geologic } \\
\text { age }\end{array}$} & \multirow[b]{2}{*}{ Zone } & \multirow[b]{2}{*}{ Marker species } & \multirow{2}{*}{$\begin{array}{l}\text { Age } \\
(\mathrm{Ma})\end{array}$} & \multicolumn{2}{|c|}{ Core, section, interval $(\mathrm{cm})$} & \multicolumn{4}{|c|}{ Depth CSF (m) } \\
\hline & & & & Top & Bottom & Top & Bottom & Midpoint & \pm \\
\hline \multirow{16}{*}{$\begin{array}{l}\text { middle } \\
\text { Miocene }\end{array}$} & RN6 & & & 320-U1336A- & 320-U1336A- & & & & \\
\hline & & B D. petterssoni & 12.11 & $1 \mathrm{H}-4,104-106$ & $1 \mathrm{H}-\mathrm{CC}$ & 5.54 & 8.19 & 6.87 & 1.33 \\
\hline & \multirow{8}{*}{ RN5 } & B C. japonica & 12.41 & $1 \mathrm{H}-4,104-106$ & $1 \mathrm{H}-\mathrm{CC}$ & 5.54 & 8.19 & 6.87 & 1.33 \\
\hline & & B L. neotera & 12.95 & $1 \mathrm{H}-\mathrm{CC}$ & $2 \mathrm{H}-2,105-107$ & 8.19 & 10.55 & 9.37 & 1.18 \\
\hline & & T C. robusta & 13.348 & $2 \mathrm{H}-\mathrm{CC}$ & $3 \mathrm{H}-2,105-107$ & 17.68 & 20.05 & 18.87 & 1.19 \\
\hline & & T S. armata & 13.5 & $2 \mathrm{H}-\mathrm{CC}$ & $3 \mathrm{H}-2,105-107$ & 17.68 & 20.05 & 18.87 & 1.19 \\
\hline & & T A. octopylus & 13.88 & $3 \mathrm{H}-2,105-107$ & $3 \mathrm{H}-4,105-107$ & 20.05 & 23.05 & 21.55 & 1.50 \\
\hline & & T C. costata & 14.229 & $3 \mathrm{H}-4,105-107$ & $3 \mathrm{H}-\mathrm{CC}$ & 23.05 & 27.47 & 25.26 & 2.21 \\
\hline & & $\mathrm{T} D$. dentata & 14.666 & $4 \mathrm{H}-2,105-107$ & $4 \mathrm{H}-4,105-107$ & 27.47 & 32.55 & 30.01 & 2.54 \\
\hline & & T L. stauropora & 14.826 & $4 \mathrm{H}-2,105-107$ & $4 \mathrm{H}-4,105-107$ & 27.47 & 32.55 & 30.01 & 2.54 \\
\hline & & D. dentata $>$ D. alata & 14.78 & $4 \mathrm{H}-2,105-107$ & $4 \mathrm{H}-4,105-107$ & 27.47 & 32.55 & 30.01 & 2.54 \\
\hline & \multirow{5}{*}{ RN4 } & B D. alata & 15.08 & $4 \mathrm{H}-\mathrm{CC}$ & $5 \mathrm{H}-2,105-107$ & 36.20 & 39.05 & 37.63 & 1.43 \\
\hline & & B L. parkerae & 15.03 & $4 \mathrm{H}-\mathrm{CC}$ & $5 \mathrm{H}-2,105-107$ & 36.20 & 39.05 & 37.63 & 1.43 \\
\hline & & T C. cingulata & 15.13 & $5 \mathrm{H}-4,105-107$ & $5 \mathrm{H}-\mathrm{CC}$ & 42.05 & 46.41 & 44.23 & 2.18 \\
\hline & & T L. elongata & 15.15 & $6 \mathrm{H}-2,105-107$ & $6 \mathrm{H}-4,105-107$ & 48.55 & 48.57 & 48.56 & 0.01 \\
\hline & & B L. renzae & 16.77 & $6 \mathrm{H}-2,105-107$ & $6 \mathrm{H}-4,105-107$ & 48.55 & 48.57 & 48.56 & 0.01 \\
\hline \multirow{20}{*}{$\begin{array}{c}\text { early } \\
\text { Miocene }\end{array}$} & & B C. costata & 17.49 & $6 \mathrm{H}-4,105-107$ & $6 \mathrm{H}-\mathrm{CC}$ & 48.57 & 55.14 & 51.86 & 3.29 \\
\hline & \multirow{4}{*}{ RN3 } & B D. dentata & 17.72 & $6 \mathrm{H}-\mathrm{CC}$ & 7H-2, 104-106 & 55.14 & 58.04 & 56.59 & 1.45 \\
\hline & & B L. stauropora & 17.72 & $6 \mathrm{H}-\mathrm{CC}$ & 7H-2, 104-106 & 55.14 & 58.04 & 56.59 & 1.45 \\
\hline & & T D. scambos & 18.53 & 7H-4, 104-106 & $\mathrm{7H}-\mathrm{CC}$ & 61.05 & 65.60 & 63.33 & 2.28 \\
\hline & & B S. wolffii & 18.57 & $8 \mathrm{H}-2,105-107$ & $8 \mathrm{H}-4,105-107$ & 67.55 & 70.55 & 69.05 & 1.50 \\
\hline & \multirow{7}{*}{ RN2 } & B D. forcipata & 18.61 & $8 \mathrm{H}-2,105-107$ & $8 \mathrm{H}-4,105-107$ & 67.55 & 70.55 & 69.05 & 1.50 \\
\hline & & T D. simplex & 18.69 & $8 \mathrm{H}-\mathrm{CC}$ & $9 \mathrm{H}-2,105-107$ & 74.38 & 77.05 & 75.72 & 1.34 \\
\hline & & T D. praeforcipata & 19.77 & $9 \mathrm{CC}$ & $10 \mathrm{H}-2,105-107$ & 84.60 & 86.56 & 85.58 & 0.98 \\
\hline & & B D. simplex & 20.34 & $10 \mathrm{H}-4,105-107$ & $10 \mathrm{H}-\mathrm{CC}$ & 89.55 & 93.78 & 91.67 & 2.12 \\
\hline & & B S. delmontensis & 20.68 & $11 \mathrm{H}-2,105-107$ & $11 \mathrm{H}-4,105-107$ & 96.05 & 99.05 & 97.55 & 1.50 \\
\hline & & T L. pegetrum & 20.89 & $11 \mathrm{H}-4,105-107$ & $11 \mathrm{H}-\mathrm{CC}$ & 99.05 & 103.48 & 101.27 & 2.22 \\
\hline & & T T. annosa & 21.38 & $12 \mathrm{H}-2,105-107$ & $12 \mathrm{H}-4,105-107$ & 105.55 & 108.55 & 107.05 & 1.50 \\
\hline & \multirow{5}{*}{ RN1 } & B C. virginis & 21.39 & $11 \mathrm{H}-\mathrm{CC}$ & $12 \mathrm{H}-2,105-107$ & 103.48 & 105.55 & 104.52 & 1.04 \\
\hline & & T E. mitodes & 21.95 & $13 \mathrm{H}-4,104-106$ & $13 \mathrm{H}-\mathrm{CC}$ & 118.04 & 122.58 & 120.31 & 2.27 \\
\hline & & B C. serrata & 22.04 & $15 \mathrm{H}-2,105-104$ & $15 \mathrm{H}-4,105-107$ & 126.05 & 129.05 & 127.55 & 1.50 \\
\hline & & B C. cornuta & 22.26 & $15 \mathrm{H}-4,105-107$ & $15 \mathrm{H}-\mathrm{CC}$ & 129.05 & 133.38 & 131.22 & 2.16 \\
\hline & & B C. tetrapera & 22.35 & $15 \mathrm{H}-4,105-107$ & $15 \mathrm{H}-\mathrm{CC}$ & 129.05 & 133.38 & 131.22 & 2.16 \\
\hline & \multirow{8}{*}{ RP22 } & T A. gracilis & 22.62 & $16 \mathrm{H}-2,105-107$ & $16 \mathrm{H}-4,105-107$ & 133.55 & 138.55 & 136.05 & 2.50 \\
\hline & & B E. diaphanes & 22.95 & $16 \mathrm{H}-\mathrm{CC}$ & $17 \mathrm{H}-2,105-107$ & 141.99 & 144.55 & 143.27 & 1.28 \\
\hline & & T D. cyclacantha & 22.98 & $16 \mathrm{H}-\mathrm{CC}$ & $17 \mathrm{H}-2,105-107$ & 141.99 & 144.55 & 143.27 & 1.28 \\
\hline \multirow{5}{*}{$\begin{array}{c}\text { late } \\
\text { Oligocene }\end{array}$} & & B D. cyclacantha & 23.29 & $17 \mathrm{H}-2,105-107$ & $17 \mathrm{H}-4,105-107$ & 144.55 & 147.55 & 146.05 & 1.50 \\
\hline & & T D. papilio & 23.31 & $17 \mathrm{H}-4,105-107$ & $17 \mathrm{H}-\mathrm{CC}$ & 147.55 & 151.84 & 149.70 & 2.15 \\
\hline & & T L. longicornuta & 24.12 & $18 \mathrm{H}-2,105-107$ & $18 \mathrm{H}-4,105-107$ & 154.04 & 157.05 & 155.55 & 1.51 \\
\hline & & T L. apodora & 24.50 & - & - & & & 0.00 & 0.00 \\
\hline & & B L. elongata & 25.05 & - & - & & & 0.00 & 0.00 \\
\hline
\end{tabular}

Notes: $\mathrm{B}=$ bottom, $\mathrm{T}=$ top. $-=$ not encountered. 
Table T6. Preservation and relative abundance of radiolarians, Hole U1336B. (See table notes.)

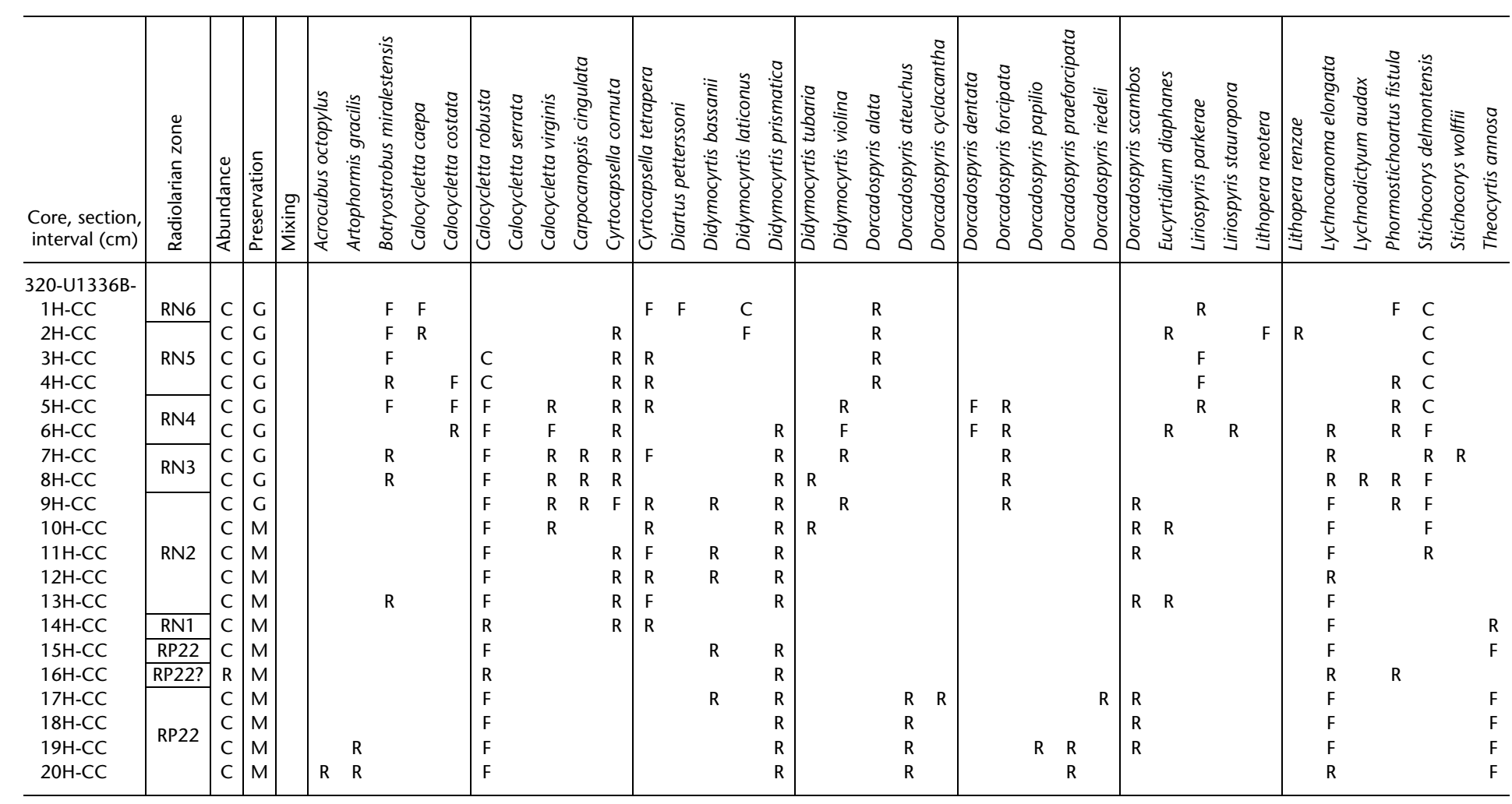

Notes: Abundance: $\mathrm{C}=$ common, $\mathrm{F}=$ frequent, $\mathrm{R}=$ rare. Preservation: $\mathrm{G}=$ good, $\mathrm{M}=$ moderate. Mixing: blank = no mixing of older specimens detected. 
Table T7. Distribution of diatoms, Site U1336. (See table notes.)

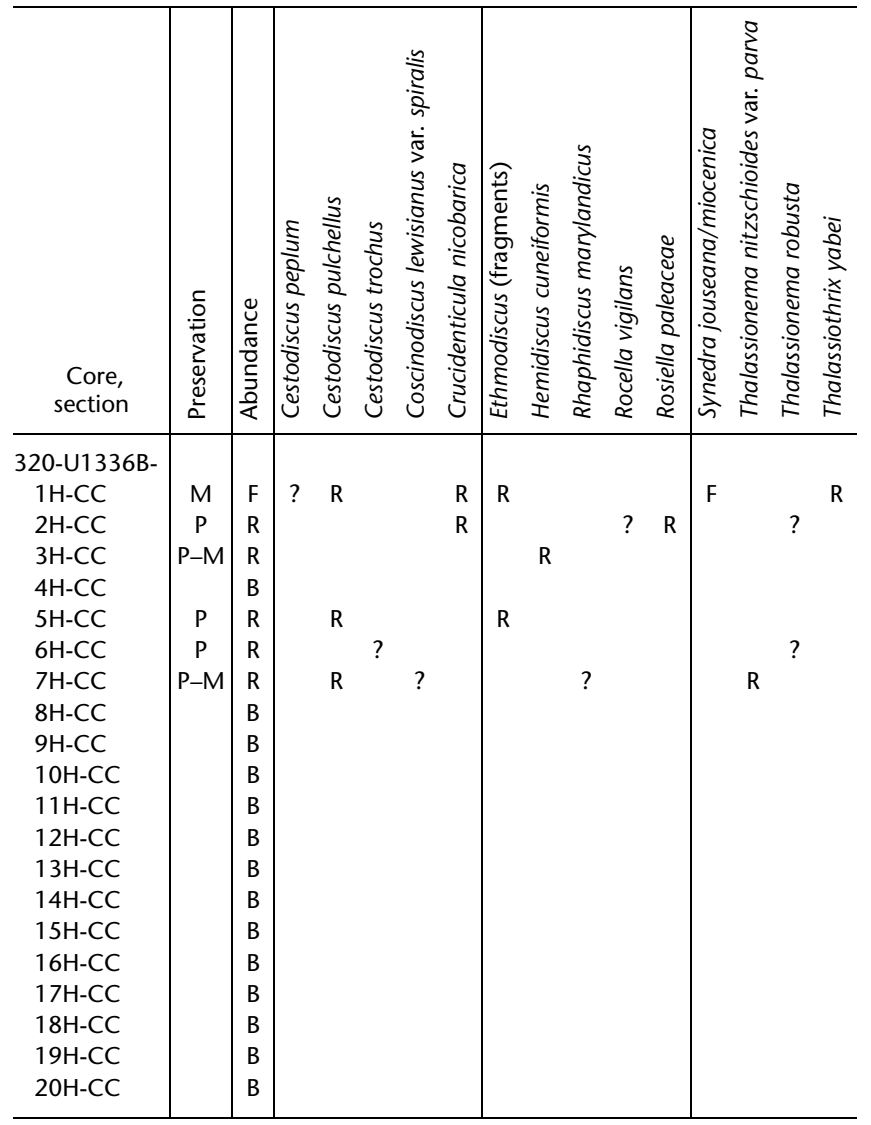

Notes: All samples are of middle Miocene age. Preservation: $M=$ moderate, $P=$ poor. Abundance: $F=$ few, $R=$ rare, $B=b a r r e n, ?=$ uncertainty. 
Table T8. Planktonic foraminifer datums, Site U1336. (See table note.)

\begin{tabular}{|c|c|c|c|c|c|c|c|}
\hline \multicolumn{2}{|c|}{ Core, section, interval $(\mathrm{cm})$} & \multirow[b]{2}{*}{ Marker species } & \multirow{2}{*}{$\begin{array}{l}\text { Age } \\
(\mathrm{Ma})\end{array}$} & \multicolumn{4}{|c|}{ Depth CSF (m) } \\
\hline Top & Bottom & & & Top & Bottom & Midpoint & \pm \\
\hline $\begin{array}{l}\text { 320-U1336A- } \\
-\end{array}$ & $\begin{array}{l}320-U 1336 \mathrm{~A}- \\
1 \mathrm{H}-3,38-40\end{array}$ & T Globorotalia (Fohsella) fohsi s.l. & 11.79 & 0.00 & 3.38 & 1.69 & 1.69 \\
\hline $1 \mathrm{H}-3,38-40$ & $1 \mathrm{H}-\mathrm{CC}$ & B Globorotalia (Fohsella) fohsi robusta & 13.13 & 3.38 & 8.19 & 5.79 & 2.41 \\
\hline $2 \mathrm{H}-\mathrm{CC}$ & $3 \mathrm{H}-2,38-40$ & B Globorotalia (Fohsella) fohsi s.l. & 13.41 & 17.68 & 19.38 & 18.53 & 0.85 \\
\hline $3 \mathrm{H}-2,38-40$ & $3 \mathrm{H}-5,38-40$ & B Globorotalia (Fohsella) "praefohsi" & 13.77 & 19.38 & 23.88 & 21.63 & 2.25 \\
\hline $3 \mathrm{H}-2,38-40$ & $3 \mathrm{H}-5,38-40$ & T Clavatorella bermudezi & 13.82 & 19.38 & 23.88 & 21.63 & 2.25 \\
\hline $3 \mathrm{H}-5,38-40$ & $3 \mathrm{H}-\mathrm{CC}$ & T Globorotalia (Fohsella) peripheroronda & 13.80 & 23.88 & 27.47 & 25.68 & 1.80 \\
\hline $3 \mathrm{H}-\mathrm{CC}$ & $4 \mathrm{H}-3,38-40$ & B Globorotalia (Fohsella) peripheroacuta & 14.24 & 27.47 & 30.38 & 28.93 & 1.46 \\
\hline $3 \mathrm{H}-5,38-40$ & $3 \mathrm{H}-\mathrm{CC}$ & B Orbulina spp. & 14.74 & 23.88 & 27.47 & 25.68 & 1.80 \\
\hline $3 \mathrm{H}-\mathrm{CC}$ & $4 \mathrm{H}-3,38-40$ & B Clavatorella bermudezi & 14.89 & 27.47 & 30.38 & 28.93 & 1.46 \\
\hline $5 \mathrm{H}-\mathrm{CC}$ & $6 \mathrm{H}-2,38-40$ & B Praeorbulina glomerosa & 16.27 & 46.41 & 47.88 & 47.15 & 0.73 \\
\hline $5 \mathrm{H}-\mathrm{CC}$ & $6 \mathrm{H}-2,38-40$ & B Praeorbulina sicana & 16.97 & 46.41 & 47.88 & 47.15 & 0.73 \\
\hline $8 \mathrm{H}-2,38-40$ & $8 \mathrm{H}-4,38-40$ & T Globoquadrina binaiensis & 19.09 & 66.88 & 69.88 & 68.38 & 1.50 \\
\hline $10 \mathrm{H}-\mathrm{CC}$ & $11 \mathrm{H}-2,30-32$ & T Paragloborotalia kugleri & 21.12 & 93.78 & 95.30 & 94.54 & 0.76 \\
\hline $10 \mathrm{H}-\mathrm{CC}$ & $11 \mathrm{H}-2,30-32$ & T Paragloborotalia pseudokugleri & 21.31 & 93.78 & 95.30 & 94.54 & 0.76 \\
\hline \multirow[t]{2}{*}{$15 \mathrm{H}-2,38-40$} & $15 \mathrm{H}-4,38-40$ & B Globoquadrina dehiscens & 22.44 & 125.38 & 128.38 & 126.88 & 1.50 \\
\hline & & Oligocene/Miocene boundary & & & & & \\
\hline $16 \mathrm{H}-\mathrm{CC}$ & $17 \mathrm{H}-2,38-40$ & B Paragloborotalia kugleri & 23.0 & 141.99 & 143.88 & 142.94 & 0.94 \\
\hline $19 \mathrm{H}-\mathrm{CC}$ & $20 \mathrm{H}-2,38-40$ & B Paragloborotalia pseudokugleri & 25.2 & 170.60 & 172.38 & 171.49 & 0.89 \\
\hline $23 \mathrm{X}-\mathrm{CC}$ & $24 X-2,41-43$ & T Paragloborotalia opima & 26.9 & 202.15 & 207.30 & 204.73 & 2.58 \\
\hline $25 X-2,45-47$ & $25 X-C C$ & Tc Chiloguembelina cubensis & 28.0 & 213.95 & 216.91 & 215.43 & 1.48 \\
\hline $27 X-C C$ & $28 X-2,20-22$ & B Globigerina angulisuturalis & 29.2 & 237.38 & 242.50 & 239.94 & 2.56 \\
\hline $29 X-2,24-26$ & $29 X-C C$ & T Subbotina angiporoides & 29.8 & 242.50 & 252.14 & 247.32 & 4.82 \\
\hline $29 \mathrm{X}-\mathrm{CC}$ & $30 X-2,38-40$ & T Turborotalia ampliapertura & 30.3 & 254.52 & 261.88 & 258.20 & 3.68 \\
\hline $29 \mathrm{X}-\mathrm{CC}$ & $30 \mathrm{X}-2,38-40$ & B Paragloborotalia opima & 30.8 & 254.52 & 261.88 & 258.20 & 3.68 \\
\hline 321-U1336B- & 321-U1336B- & & & & & & \\
\hline $1 \mathrm{H}-\mathrm{CC}$ & $2 \mathrm{H}-\mathrm{CC}$ & B Globorotalia (Fohsella) fohsi robusta & 13.13 & 1.73 & 11.85 & 6.79 & 5.06 \\
\hline $2 \mathrm{H}-\mathrm{CC}$ & $3 \mathrm{H}-\mathrm{CC}$ & B Globorotalia (Fohsella) fohsi s.l. & 13.41 & 11.88 & 21.13 & 16.51 & 4.63 \\
\hline $2 \mathrm{H}-\mathrm{CC}$ & $3 \mathrm{H}-\mathrm{CC}$ & B Globorotalia (Fohsella) "praefohsi" & 13.77 & 11.88 & 21.13 & 16.51 & 4.63 \\
\hline $2 \mathrm{H}-\mathrm{CC}$ & $3 \mathrm{H}-\mathrm{CC}$ & T Clavatorella bermudezi & 13.82 & 11.88 & 21.13 & 16.51 & 4.63 \\
\hline $3 \mathrm{H}-\mathrm{CC}$ & $4 \mathrm{H}-\mathrm{CC}$ & B Globorotalia (Fohsella) peripheroacuta & 14.24 & 21.16 & 30.54 & 25.85 & 4.69 \\
\hline $3 \mathrm{H}-\mathrm{CC}$ & $4 \mathrm{H}-\mathrm{CC}$ & B Orbulina spp. & 14.74 & 21.16 & 30.54 & 25.85 & 4.69 \\
\hline $3 \mathrm{H}-\mathrm{CC}$ & $4 \mathrm{H}-\mathrm{CC}$ & B Clavatorella bermudezi & 14.89 & 21.16 & 30.54 & 25.85 & 4.69 \\
\hline $4 \mathrm{H}-\mathrm{CC}$ & $5 \mathrm{H}-\mathrm{CC}$ & B Praeorbulina glomerosa & 16.27 & 30.57 & 40.27 & 35.42 & 4.85 \\
\hline $5 \mathrm{H}-\mathrm{CC}$ & $6 \mathrm{H}-\mathrm{CC}$ & B Praeorbulina sicana & 16.97 & 40.30 & 49.87 & 45.09 & 4.79 \\
\hline 7H-CC & $8 \mathrm{H}-\mathrm{CC}$ & T Catapsydrax dissimilis & 17.54 & 58.68 & 68.45 & 63.57 & 4.89 \\
\hline $8 \mathrm{H}-\mathrm{CC}$ & $9 \mathrm{H}-\mathrm{CC}$ & T Globoquadrina binaiensis & 19.09 & 68.50 & 77.72 & 73.11 & 4.61 \\
\hline $11 \mathrm{H}-\mathrm{CC}$ & $12 \mathrm{H}-\mathrm{CC}$ & T Paragloborotalia kugleri & 21.12 & 97.25 & 106.54 & 101.90 & 4.65 \\
\hline $13 \mathrm{H}-\mathrm{CC}$ & $14 \mathrm{H}-\mathrm{CC}$ & T Paragloborotalia pseudokugleri & 21.31 & 116.41 & 125.84 & 121.13 & 4.72 \\
\hline $14 \mathrm{H}-\mathrm{CC}$ & $15 \mathrm{H}-\mathrm{CC}$ & B Globoquadrina dehiscens & 22.44 & 125.84 & 134.83 & 130.34 & 4.50 \\
\hline \multirow[t]{2}{*}{$16 \mathrm{H}-1,52-54$} & $17 \mathrm{H}-3,80-82$ & T Globigerina ciperoensis & 22.90 & 134.83 & 140.60 & 137.72 & 2.88 \\
\hline & & Oligocene/Miocene boundary & & & & & \\
\hline $16 \mathrm{H}-1,52-54$ & $17 \mathrm{H}-3,80-82$ & B Paragloborotalia kugleri & 23.0 & 134.83 & 140.60 & 137.72 & 2.88 \\
\hline
\end{tabular}

Note: $\mathrm{T}=$ top, $\mathrm{B}=$ bottom, $\mathrm{Tc}=$ top common occurrence. 
Table T10. Distribution of planktonic foraminifers, Hole U1336B. (See table notes.) (Continued on next page.)

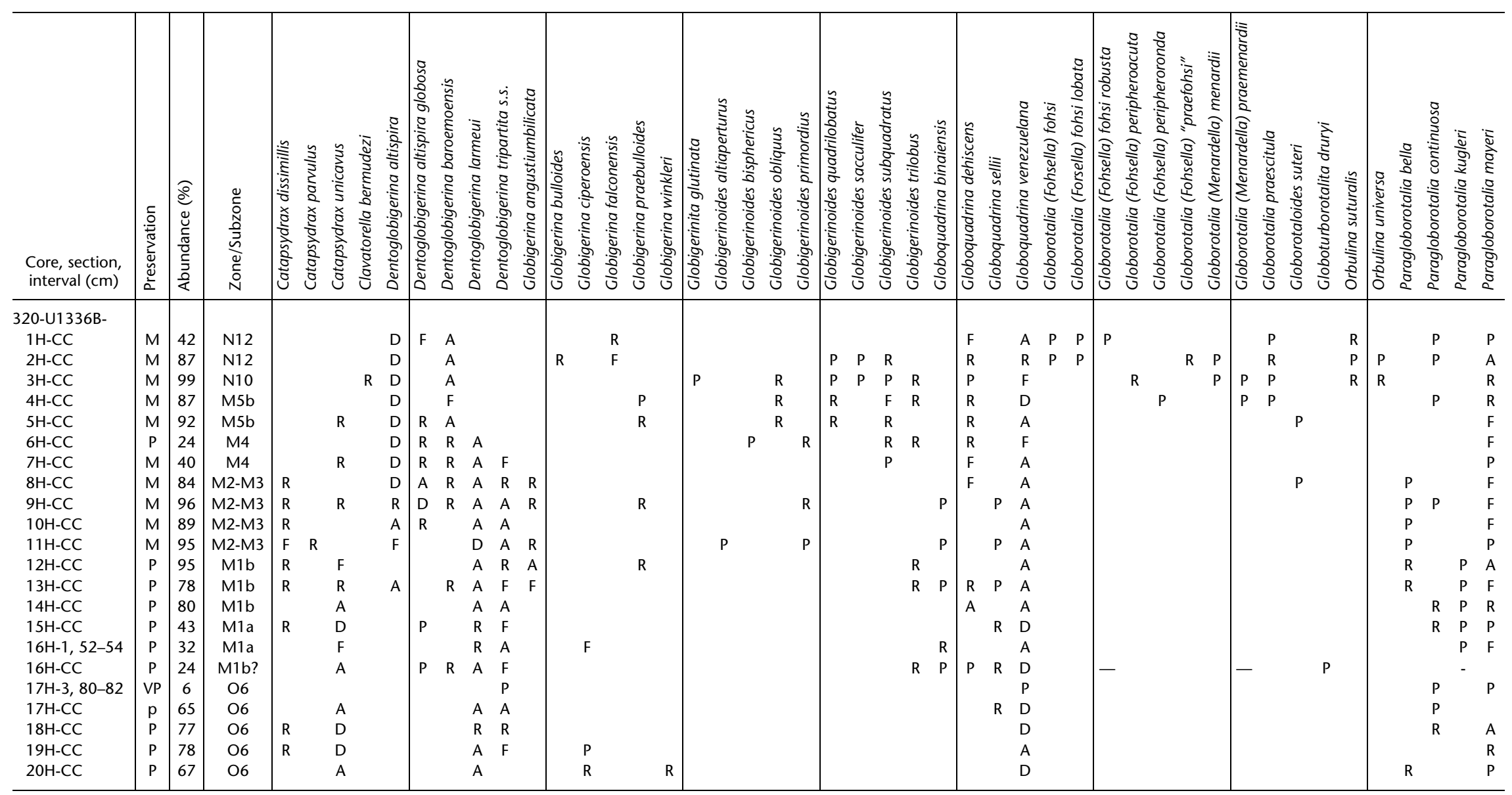

Notes: Preservation: $M=$ moderate, $P=$ poor, $V P=$ very poor. Abundance: $D=$ dominant,$A=$ abundant, $F=$ few, $R=$ rare, $P=$ present, $-=$ flow-in. 


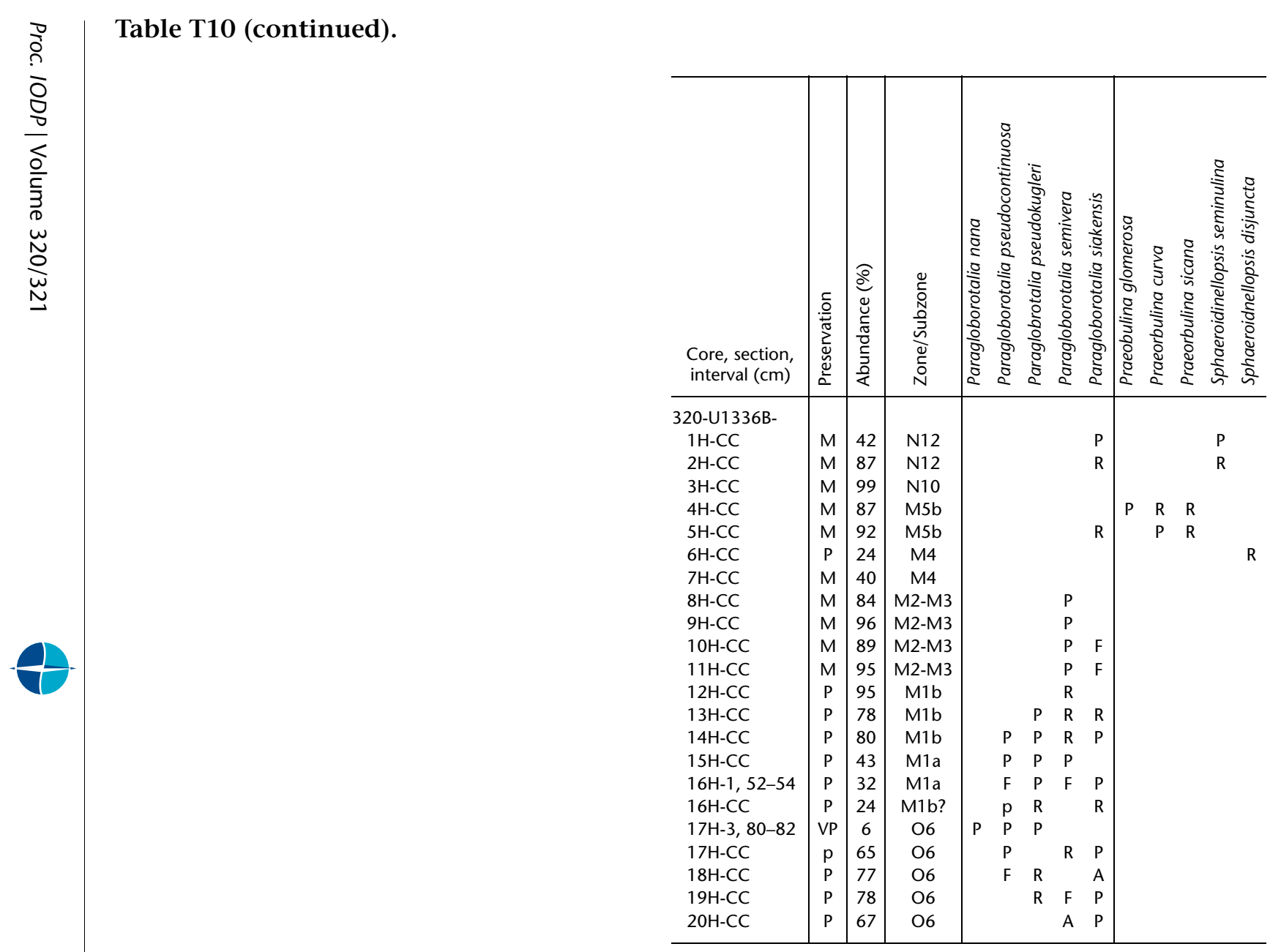




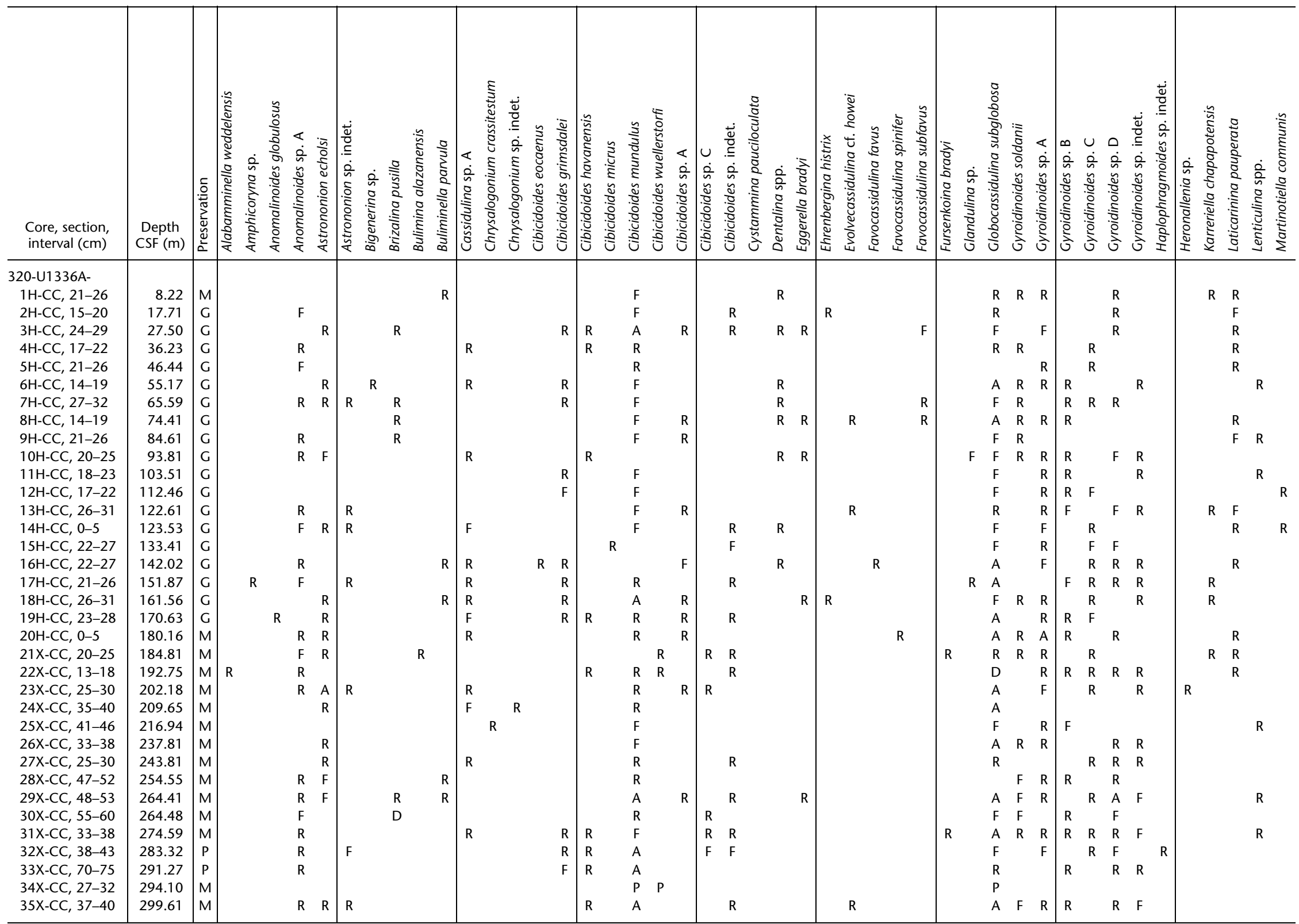




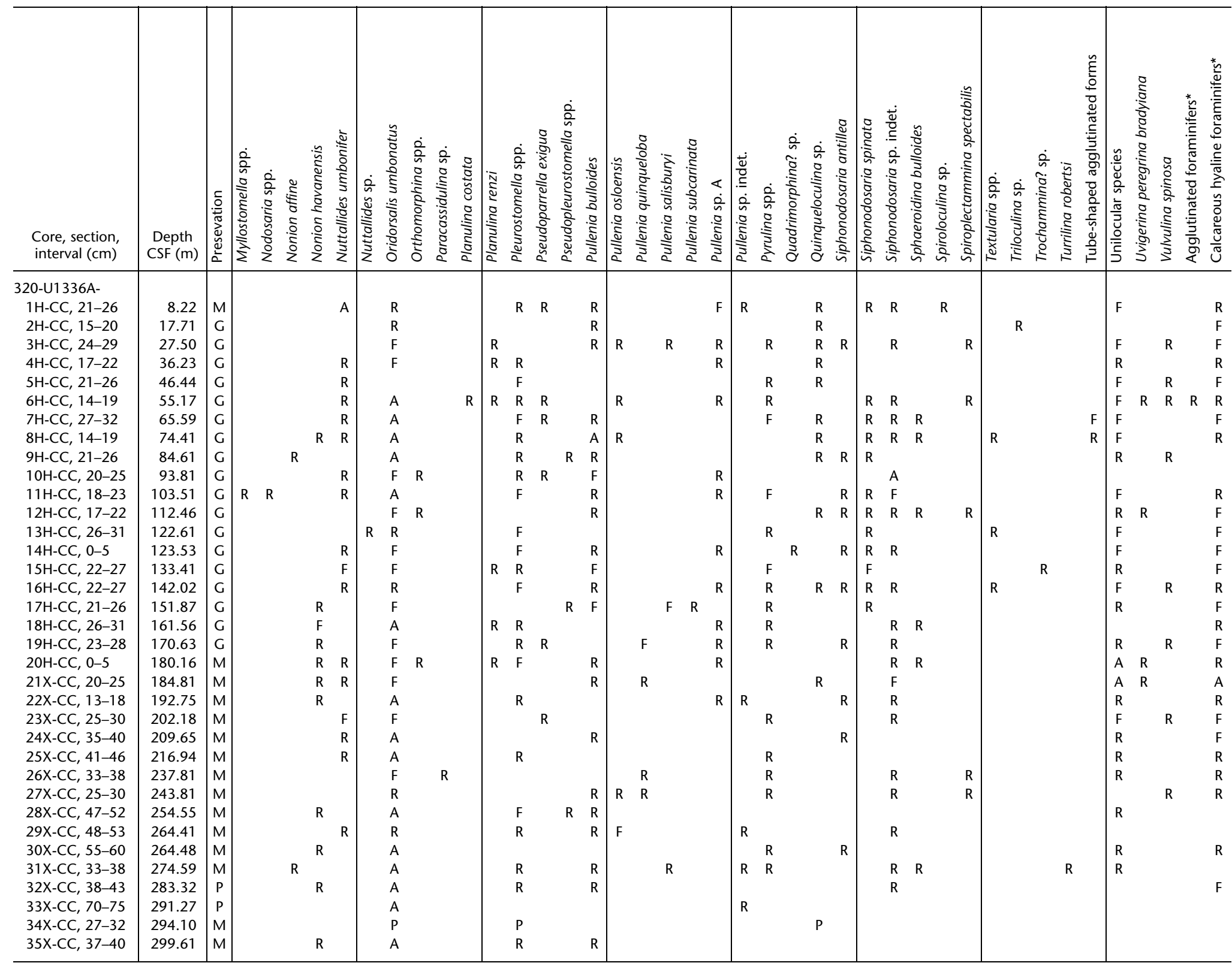


Table T12. Distribution of benthic foraminifers, Hole U1336B. (See table notes.) (Continued on next page.)

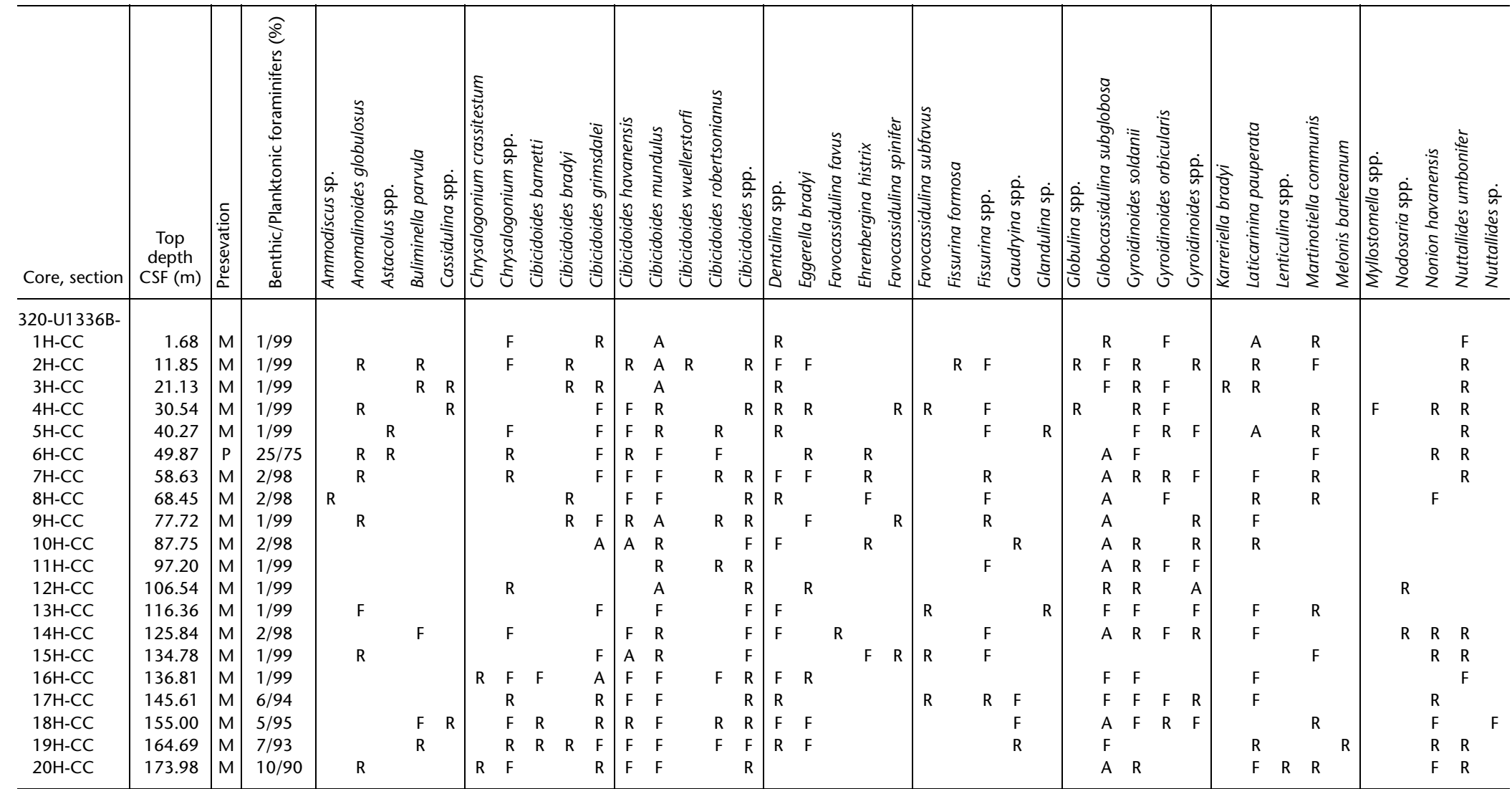

Notes: Bathymetry is lower bathyal to abyssal zones. Preservation: $\mathrm{M}=$ moderate, $\mathrm{P}=$ poor. Abundance: $\mathrm{A}=$ abundant, $\mathrm{F}=$ few, $\mathrm{R}=$ rare. ${ }^{*}=\mathrm{genus}$ and species indeterminate. 


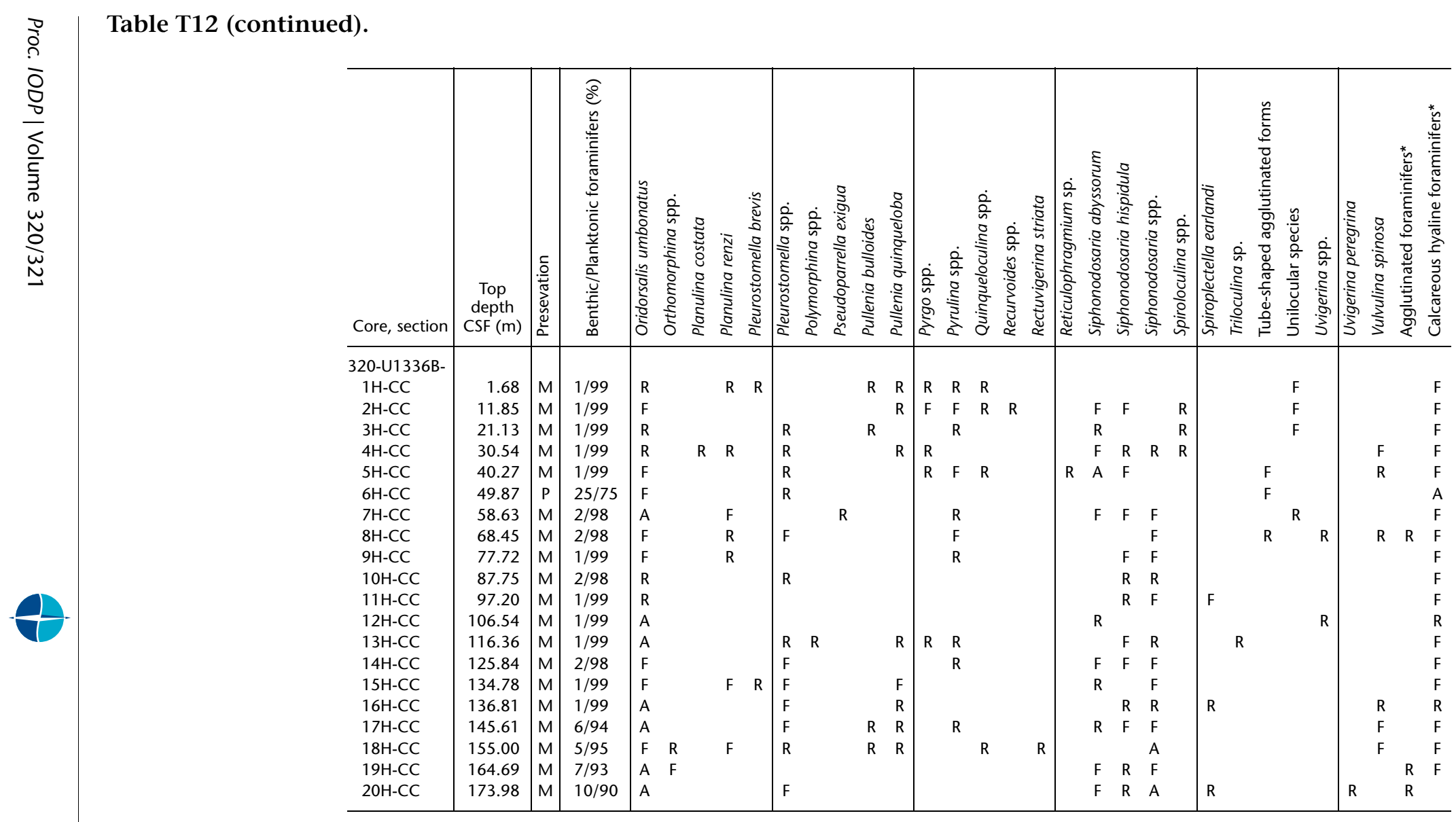


Table T13. Coring-disturbed intervals and gaps, Site U1336. (See table notes.)

\begin{tabular}{|c|c|}
\hline $\begin{array}{l}\text { Core, section, } \\
\text { interval }(\mathrm{cm})\end{array}$ & $\begin{array}{c}\text { Type of } \\
\text { disturbance }\end{array}$ \\
\hline \multicolumn{2}{|l|}{ 320-U1336A- } \\
\hline $1 \mathrm{H}-1,0-31$ & Minor \\
\hline $2 \mathrm{H}-1,0-76$ & Top of core \\
\hline $3 \mathrm{H}-1,0-127$ & Top of core \\
\hline $4 \mathrm{H}-1,0-142$ & Top of core \\
\hline $5 \mathrm{H}-1,0-12$ & Top of core \\
\hline $6 \mathrm{H}-1,0-34$ & Top of core \\
\hline $10 \mathrm{H}-1,0-64$ & Top of core \\
\hline $11 \mathrm{H}-1,0-6$ & Top of core \\
\hline $12 \mathrm{H}-1,0-84$ & Top of core \\
\hline $12 \mathrm{H}-7,8-70$ & Distorted liner \\
\hline $13 \mathrm{H}-1,0-111$ & Top of core \\
\hline $14 \mathrm{H}-1,0-150$ & Slurry \\
\hline $15 \mathrm{H}-1,0-30$ & Top of core \\
\hline $16 \mathrm{H}-1,0-82$ & Top of core \\
\hline $16 \mathrm{H}-3,100-150$ & Slight \\
\hline $16 \mathrm{H}-4,94-150$ & Drilling biscuits \\
\hline $16 \mathrm{H}-5,0-5$ & Drilling biscuits \\
\hline $16 \mathrm{H}-5,5-150$ & Flow-in \\
\hline $16 \mathrm{H}-6,0-127$ & Flow-in \\
\hline $17 \mathrm{H}-1,0-12$ & Top of core \\
\hline $19 \mathrm{H}-1,0-25$ & Top of core \\
\hline $21 \mathrm{H}-1,0-42$ & Top of core \\
\hline $22 \mathrm{X}-35 \mathrm{X}$, all sections & Drilling biscuits \\
\hline \multicolumn{2}{|l|}{ 320-U1336B- } \\
\hline $2 \mathrm{H}-1,0-60$ & Top of core \\
\hline $2 \mathrm{H}-1,85-87$ & Void \\
\hline $4 \mathrm{H}-1,0-25$ & Top of core \\
\hline $5 \mathrm{H}-1,0-5$ & Top of core \\
\hline $6 \mathrm{H}-1,0-50$ & Top of core \\
\hline $7 \mathrm{H}-1,0-55$ & Top of core \\
\hline $8 \mathrm{H}-1,0-60$ & Top of core \\
\hline $9 \mathrm{H}-1,0-130$ & Top of core \\
\hline $10 \mathrm{H}-1,0-10$ & Top of core \\
\hline $11 \mathrm{H}-1,0-20$ & Top of core \\
\hline $12 \mathrm{H}-1,0-20$ & Top of core \\
\hline $13 \mathrm{H}-1,0-10$ & Top of core \\
\hline $14 \mathrm{H}-1,0-10$ & Top of core \\
\hline $14 \mathrm{H}-4,122-150$ & Flow-in \\
\hline $14 \mathrm{H}-5,0-150$ & Flow-in \\
\hline $14 \mathrm{H}-6,0-150$ & Flow-in \\
\hline $14 \mathrm{H}-7,0$-end & Flow-in \\
\hline $15 \mathrm{H}-1,0-30$ & Top of core \\
\hline $16 \mathrm{H}-1,0-15$ & Top of core \\
\hline $16 \mathrm{H}-2,0-150$ & Disturbed \\
\hline $17 \mathrm{H}-1,0-15$ & Top of core \\
\hline $18 \mathrm{H}-1,0-20$ & Top of core \\
\hline $19 \mathrm{H}-1,0-10$ & Top of core \\
\hline $20 \mathrm{H}-1,0-10$ & Top of core \\
\hline $20 \mathrm{H}-7,20$-end & Deformed liner \\
\hline
\end{tabular}

Notes: When interval listed is $0-150 \mathrm{~cm}$, entire section is included even if true section length is $<150 \mathrm{~cm}$. Top of core $=$ myriad forms of voids, disturbance, and debris from uphole that affect top portion of most cores. For that reason, probably the top $20 \mathrm{~cm}$ or so of all cores should be avoided. 
Table T14. Principal component analysis results, Hole U1336A. (See table notes.)

\begin{tabular}{|c|c|c|c|c|c|c|c|}
\hline \multirow[b]{3}{*}{$\begin{array}{l}\text { Core, section, } \\
\text { interval }(\mathrm{cm})\end{array}$} & \multirow[b]{3}{*}{$\begin{array}{l}\text { Depth } \\
\operatorname{CSF}(\mathrm{m})\end{array}$} & \multicolumn{5}{|c|}{ PCA } & \multirow[b]{3}{*}{$\begin{array}{l}\mathrm{NRM} \\
(\mathrm{A} / \mathrm{m})\end{array}$} \\
\hline & & \multicolumn{2}{|c|}{ Declination } & \multirow[b]{2}{*}{$\begin{array}{l}\text { Inclination } \\
\left({ }^{\circ}\right)\end{array}$} & \multirow[b]{2}{*}{$\begin{array}{l}\text { MAD } \\
\left({ }^{\circ}\right)\end{array}$} & \multirow[b]{2}{*}{$\begin{array}{l}\text { Range } \\
(\mathrm{mT})\end{array}$} & \\
\hline & & $\begin{array}{l}\text { Azimuthally } \\
\text { unoriented }\left({ }^{\circ}\right)\end{array}$ & $\begin{array}{c}\text { Geographical } \\
\text { coordinates } \\
0^{\circ}-360^{\circ}\end{array}$ & & & & \\
\hline \multicolumn{8}{|l|}{ 320-U1336A- } \\
\hline $1 \mathrm{H}-2,85$ & 2.35 & 319.2 & 325.7 & 5.9 & 3.5 & $10-35$ & $6.58 \mathrm{E}-04$ \\
\hline $2 \mathrm{H}-2,85$ & 10.35 & 200.7 & 164.8 & -5.2 & 15.9 & $20-50$ & $6.99 \mathrm{E}-04$ \\
\hline $3 \mathrm{H}-2,85$ & 19.85 & 301.7 & 13.0 & 24.2 & 10.3 & $5-25$ & $6.05 \mathrm{E}-04$ \\
\hline $4 \mathrm{H}-2,85$ & 29.35 & NA & & NA & NA & NA & $9.41 \mathrm{E}-05$ \\
\hline $5 \mathrm{H}-2,85$ & 38.85 & 312.1 & 168.1 & 3.8 & 33.5 & $5-60$ & $3.77 \mathrm{E}-04$ \\
\hline $6 \mathrm{H}-2,85$ & 48.35 & 117.3 & 7.3 & 4.8 & 5.5 & $10-30$ & $1.03 \mathrm{E}-03$ \\
\hline $7 \mathrm{H}-2,85$ & 57.85 & 11.1 & 156.1 & -1.6 & 5.8 & $20-50$ & $1.79 \mathrm{E}-03$ \\
\hline $8 \mathrm{H}-2,85$ & 67.35 & 316.3 & 355.3 & 21.0 & 17.3 & $25-60$ & $6.78 \mathrm{E}-04$ \\
\hline $9 \mathrm{H}-2,85$ & 76.85 & 108.6 & 312.6 & 17.8 & 41.2 & $10-60$ & 4.69E-04 \\
\hline $10 \mathrm{H}-2,85$ & 86.35 & NA & & NA & NA & NA & $2.20 \mathrm{E}-04$ \\
\hline $11 \mathrm{H}-2,85$ & 95.85 & NA & & NA & NA & NA & $6.62 \mathrm{E}-05$ \\
\hline $12 \mathrm{H}-2,85$ & 105.35 & NA & & NA & NA & NA & 9.97E-05 \\
\hline $13 \mathrm{H}-2,85$ & 114.85 & NA & & NA & NA & NA & $1.59 \mathrm{E}-04$ \\
\hline $15 \mathrm{H}-2,85$ & 125.85 & 176.1 & 8.1 & 19.2 & 11.1 & $5-25$ & 7.47E-05 \\
\hline $16 \mathrm{H}-2,85$ & 135.35 & NA & & NA & NA & NA & $1.00 \mathrm{E}-04$ \\
\hline $17 \mathrm{H}-2,85$ & 144.35 & NA & & NA & NA & NA & 2.44E-04 \\
\hline $18 \mathrm{H}-2,85$ & 153.85 & NA & & NA & NA & NA & $1.82 \mathrm{E}-04$ \\
\hline $19 \mathrm{H}-2,85$ & 163.35 & 18.4 & 94.4 & -37.8 & 24.1 & $5-30$ & $2.39 \mathrm{E}-04$ \\
\hline $20 \mathrm{H}-2,85$ & 172.85 & NA & & NA & NA & NA & $2.23 \mathrm{E}-04$ \\
\hline $21 \mathrm{H}-2,85$ & 182.35 & 203.9 & 348.9 & 59.9 & 11.8 & $5-25$ & $2.29 \mathrm{E}-04$ \\
\hline
\end{tabular}

Notes: $\mathrm{PCA}=$ principal component analysis, $\mathrm{MAD}=$ maximum angular deviation, $\mathrm{NRM}=$ natural remanent magnetization after $20 \mathrm{mT}$ demagnetization. NA = not applicable. 
Table T15. Interpretation of polarity stratigraphy, Site U1336.

\begin{tabular}{|c|c|c|c|c|c|c|c|}
\hline \multirow[b]{2}{*}{ Chron } & \multirow[b]{2}{*}{$\begin{array}{l}\text { Age } \\
\text { (Ma) }\end{array}$} & \multicolumn{3}{|c|}{ Hole U1336A } & \multicolumn{3}{|c|}{ Hole U1336B } \\
\hline & & $\begin{array}{c}\text { Core, section, } \\
\text { interval }(\mathrm{cm})\end{array}$ & $\begin{array}{l}\text { Depth } \\
\text { CSF (m) }\end{array}$ & $\begin{array}{c}\text { Depth } \\
\text { CCSF-A }(\mathrm{m})\end{array}$ & $\begin{array}{l}\text { Core, section, } \\
\text { interval }(\mathrm{cm})\end{array}$ & $\begin{array}{l}\text { Depth } \\
\text { CSF (m) }\end{array}$ & $\begin{array}{c}\text { Depth } \\
\text { CCSF-A (m) }\end{array}$ \\
\hline $\mathrm{C} 1 \mathrm{n}$ & 0.000 & & & & & & \\
\hline C5r.3r/C5An.1n & 12.014 & $1 \mathrm{H}-1,52$ & 0.50 & 0.76 & $1 \mathrm{H}-1,82$ & 0.83 & 0.83 \\
\hline C5An.1n/C5An.1r & 12.116 & $1 \mathrm{H}-1,145$ & 1.43 & 1.69 & & & \\
\hline C5An.1r/C5An.2n & 12.207 & $1 \mathrm{H}-2,67$ & 2.14 & 2.40 & & & \\
\hline C5An.2n/C5Ar.1r & 12.415 & $1 \mathrm{H}-4,70$ & 5.20 & 5.46 & $2 \mathrm{H}-3,25$ & 5.05 & 5.58 \\
\hline C5Ar.1r/C5Ar.1n & 12.730 & & & & $2 \mathrm{H}-5,105$ & 8.85 & 9.38 \\
\hline C5Ar.1n/C5Ar.2r & 12.765 & & & & $2 \mathrm{H}-5,142$ & 9.22 & 9.75 \\
\hline C5Ar.2r/C5Ar.2n & 12.820 & $2 \mathrm{H}-1,102$ & 9.02 & 10.53 & $2 \mathrm{H}-6,68$ & 9.97 & 10.50 \\
\hline C5Ar.2n/C5Ar.3r & 12.878 & $2 \mathrm{H}-1,132$ & 9.34 & 10.85 & $2 \mathrm{H}-6,115$ & 10.47 & 11.00 \\
\hline C5Ar.3r/C5AAn & 13.015 & $2 \mathrm{H}-2,140$ & 10.89 & 12.40 & & & \\
\hline C5AAn/C5AAr & 13.183 & $2 \mathrm{H}-3,137$ & 12.37 & 13.88 & $3 \mathrm{H}-1,115$ & 11.44 & 14.00 \\
\hline C5AAr/C5ABn & 13.369 & $2 \mathrm{H}-5,15$ & 14.15 & 15.66 & $3 \mathrm{H}-2,35$ & 13.14 & 15.70 \\
\hline $\mathrm{C} 5 \mathrm{ABn} / \mathrm{C} 5 \mathrm{ABr}$ & 13.605 & & & & $3 \mathrm{H}-4,107$ & 16.88 & 19.44 \\
\hline $\mathrm{C} 5 \mathrm{ABr} / \mathrm{C} 5 \mathrm{ACn}$ & 13.734 & $3 \mathrm{H}-2,35$ & 19.35 & 21.18 & $3 \mathrm{H}-5,140$ & 18.69 & 21.25 \\
\hline C5ADn/C5ADr & 14.581 & & & & $4 \mathrm{H}-5,5$ & 26.82 & 31.00 \\
\hline C5ADr/C5Bn.1n & 14.784 & $4 \mathrm{H}-2,75$ & 29.25 & 32.05 & $4 \mathrm{H}-5,135$ & 28.12 & 32.30 \\
\hline C5Bn.1n/C5Bn.1r & 14.877 & $4 \mathrm{H}-3,20$ & 30.15 & 32.95 & $4 \mathrm{H}-6,52$ & 28.82 & 33.00 \\
\hline C5Bn.1r/C5Bn.2n & 15.032 & $4 \mathrm{H}-4,42$ & 31.95 & 34.75 & & & \\
\hline $\mathrm{C} 5 \mathrm{Bn} \cdot 2 \mathrm{n} / \mathrm{C} 5 \mathrm{Br}$ & 15.160 & $4 \mathrm{H}-5,55$ & 33.55 & 36.35 & $5 \mathrm{H}-1,50$ & 30.80 & 36.38 \\
\hline $\mathrm{C} 5 \mathrm{Br} / \mathrm{C} 5 \mathrm{Cn} .1 \mathrm{n}$ & 15.974 & $5 \mathrm{H}-6,102$ & 45.02 & 48.30 & $6 \mathrm{H}-1,105$ & 40.85 & 48.38 \\
\hline C5Cn.1n/C5Cn.1r & 16.268 & & & & $6 \mathrm{H}-4,20$ & 44.47 & 52.00 \\
\hline C5Cn.1r/C5Cn.2n & 16.303 & $6 \mathrm{H}-1,35$ & 46.36 & 53.00 & $6 \mathrm{H}-4,127$ & 45.57 & 53.10 \\
\hline C5Cn.2n/C5Cn.2r & 16.472 & $6 \mathrm{H}-1,100$ & 47.01 & 53.65 & $6 \mathrm{H}-5,35$ & 46.15 & 53.68 \\
\hline C5Cn.2r/C5Cn.3n & 16.543 & $6 \mathrm{H}-2,30$ & 47.80 & 54.44 & $6 \mathrm{H}-5,107$ & 46.87 & 54.40 \\
\hline $\mathrm{C} 5 \mathrm{Cn} .3 \mathrm{n} / \mathrm{C} 5 \mathrm{Cr}$ & 16.721 & $6 \mathrm{H}-2,110$ & 48.61 & 55.25 & $6 \mathrm{H}-6,37$ & 47.67 & 55.20 \\
\hline $\mathrm{C} 5 \mathrm{Cr} / \mathrm{C5Dn}$ & 17.235 & $6 \mathrm{H}-5,82$ & 52.82 & 59.46 & $7 \mathrm{H}-1,150$ & 50.81 & 59.50 \\
\hline C5Dn/C5Dr & 17.533 & & & & $7 \mathrm{H}-3,137$ & 53.68 & 62.37 \\
\hline C5Dr/C5Dr-1n & 17.717 & & & & $7 \mathrm{H}-5,50$ & 55.81 & 64.50 \\
\hline C5Dr-1n/C5Dr & 17.740 & $7 \mathrm{H}-2,5$ & 57.06 & 65.10 & $7 \mathrm{H}-5,102$ & 56.31 & 65.00 \\
\hline C5Dr/C5En & 18.056 & 7H-3, 105 & 59.56 & 67.60 & & & \\
\hline C5En/C5Er & 18.524 & $7 \mathrm{H}-6,140$ & 64.40 & 72.44 & $8 \mathrm{H}-4,42$ & 63.72 & 72.60 \\
\hline C5Er/C6n & 18.748 & $8 \mathrm{H}-1,92$ & 65.91 & 75.00 & $8 \mathrm{H}-5,120$ & 66.00 & 74.88 \\
\hline
\end{tabular}


Table T16. Interstitial water data from squeezed whole-round samples, Hole U1336B. (See table notes.)

\begin{tabular}{|c|c|c|c|c|c|c|c|c|c|c|c|c|c|c|c|c|c|}
\hline $\begin{array}{l}\text { Core, section, } \\
\text { interval }(\mathrm{cm})\end{array}$ & $\begin{array}{l}\text { Depth } \\
\text { CSF }(m)\end{array}$ & $\mathrm{pH}$ & $\begin{array}{l}\text { Alkalinity } \\
(\mathrm{mM})\end{array}$ & $\begin{array}{c}\mathrm{Cl}^{-} \\
(\mathrm{mM})\end{array}$ & $\begin{array}{l}\mathrm{Na}^{+} \\
(\mathrm{mM})\end{array}$ & $\begin{array}{l}\mathrm{SO}_{4}{ }^{2-} \\
(\mathrm{mM})\end{array}$ & $\begin{array}{l}\mathrm{HPO}_{4}^{-} \\
(\mu \mathrm{M})\end{array}$ & $\begin{array}{c}\mathrm{H}_{4} \mathrm{SiO}_{4} \\
(\mu \mathrm{M})\end{array}$ & $\begin{array}{l}\mathrm{Mn}^{2+} \\
(\mu \mathrm{M})\end{array}$ & $\begin{array}{l}\mathrm{Fe}^{2+} \\
(\mu \mathrm{M})\end{array}$ & $\begin{array}{l}\mathrm{Ca}^{2+} \\
(\mathrm{mM})\end{array}$ & $\begin{array}{l}\mathrm{Mg}^{2+} \\
(\mathrm{mM})\end{array}$ & $\begin{array}{c}\mathrm{B} \\
(\mu \mathrm{M})\end{array}$ & $\begin{array}{l}\mathrm{Sr}^{2+} \\
(\mu \mathrm{M})\end{array}$ & $\begin{array}{l}\mathrm{Ba}^{2+} \\
(\mu \mathrm{M})\end{array}$ & $\begin{array}{c}\mathrm{Li}^{+} \\
(\mu \mathrm{M})\end{array}$ & $\begin{array}{c}\mathrm{K}^{+} \\
(\mathrm{mM})\end{array}$ \\
\hline \multicolumn{18}{|l|}{ 320-U1336B- } \\
\hline $2 \mathrm{H}-2,145-15$ & 4.75 & 7.71 & 2.39 & 556 & ND & 26.2 & 1.65 & 329 & $\mathrm{BDL}$ & $\mathrm{BDL}$ & 10.1 & 50.0 & 422.5 & 83.7 & $\mathrm{BDL}$ & 23.88 & ND \\
\hline $2 \mathrm{H}-5,145-150$ & 9.25 & 7.96 & 2.71 & 557 & ND & 25.9 & 4.7 & 325 & & & 10.6 & 49.0 & 439.5 & 93.8 & $\mathrm{BDL}$ & 22 & ND \\
\hline $3 \mathrm{H}-2,145-150$ & 14.25 & 7.73 & 2.66 & 561 & ND & 26.9 & 0.91 & 426 & BDL & BDL & 11.6 & 49.9 & 455.0 & 109.5 & $\mathrm{BDL}$ & 23.16 & ND \\
\hline $3 \mathrm{H}-5,145-150$ & 18.75 & 7.75 & 2.69 & 559 & 488 & 26.0 & 0.43 & 514 & BDL & BDL & 11.7 & 48.1 & 461.2 & 115.6 & & 22.93 & 11.4 \\
\hline $4 \mathrm{H}-2,145-150$ & 23.75 & 7.78 & 2.72 & 563 & 492 & 25.4 & 0. & 47 & 0.18 & BDL & 12 & 46 & 454.9 & 21.9 & & 1.54 & 10.7 \\
\hline $4 \mathrm{H}-5,145-150$ & 28.25 & 7.74 & 2.84 & 566 & 491 & 26.8 & 0.3 & 564 & 1.11 & BDL & 13.7 & 48.1 & 452.1 & 134.6 & & 33 & 11.9 \\
\hline $5 \mathrm{H}-2,145-150$ & 33.25 & 7.76 & 2.79 & 568 & 496 & 25.1 & 0.42 & 488 & 2.91 & $\mathrm{BDL}$ & 13.8 & 45.9 & 433.4 & 142.9 & 0.51 & 21.29 & 10.3 \\
\hline $5 \mathrm{H}$ & 3 & 7.69 & 2.8 & 570 & 496 & 2 & & & 4. & $\mathrm{BL}$ & 14 & 46 & 4 & 8 & & 0.18 & 10.8 \\
\hline $6 \mathrm{H}-2,1$ & 42.75 & 7.62 & 2.7 & 567 & 49 & 24. & 0.42 & 5 & 5.53 & $\mathrm{BDL}$ & 14.5 & 44 & 438.2 & 154.5 & & 19.81 & 10.4 \\
\hline $6 \mathrm{H}-5,145-150$ & 47.25 & 7.61 & 2.60 & 567 & 491 & 27.3 & 0.40 & 594 & 5.38 & $\mathrm{BDL}$ & 15.8 & 47.6 & 436.8 & 157.6 & & 19.40 & 11.2 \\
\hline & & 7.70 & & 567 & 49 & & & & 623 & $B_{1}$ & & & & & & & 10.5 \\
\hline $8 \mathrm{H}-3,140-150$ & 63.20 & 7.76 & 2.63 & 565 & 493 & 24.6 & .29 & 607 & 6.29 & $\mathrm{BDL}$ & 16.0 & 43.5 & 430.5 & 176.9 & $\mathrm{BDL}$ & 17.50 & 9.9 \\
\hline $9 \mathrm{H}-3,140-150$ & 72.70 & 7.45 & 2.63 & 565 & 490 & 24.7 & 0.32 & 633 & 5.82 & $\mathrm{BDL}$ & 16.9 & 43.7 & 419.6 & 186.1 & $\mathrm{BDL}$ & 16.98 & 9.8 \\
\hline $10 \mathrm{H}-4,1$ & 83.70 & 7.59 & & 566 & 488 & 26.0 & & & 437 & RDI & 18.5 & 45.1 & & 201.0 & & 16.46 & 10.1 \\
\hline $11 \mathrm{H}-4,1$ & 93.20 & 7.61 & 2 & 567 & 493 & 24 & 0.27 & 68 & 3.17 & $\mathrm{BDL}$ & 18.3 & 41 & 406.5 & 211.4 & $\mathrm{BDL}$ & 16.54 & 9.3 \\
\hline $12 \mathrm{H}-4,140-150$ & 102.70 & 7.59 & 2.30 & 568 & 490 & 25.0 & 0.30 & 724 & 2.74 & 4.36 & 19.4 & 43.3 & 427.9 & 220.5 & $\mathrm{BDL}$ & 15.49 & 10.0 \\
\hline & & 7.78 & 2.66 & 567 & 492 & 24.0 & 0.35 & 730 & 2.34 & & 19.5 & 4 & & 231.1 & & & 9.4 \\
\hline 14 & 121 & 7.45 & ? & 56 & 492 & 24 & BD & 6 & 2.12 & 9.92 & 20 & 40.8 & 0 & 236.5 & $B_{B}$ & 14.06 & 9.3 \\
\hline $15 \mathrm{H}-4,140-150$ & 131.20 & 7.44 & 1.73 & 566 & 494 & 23.9 & $\mathrm{BDL}$ & 671 & 1.61 & 18.43 & 26.4 & 32.5 & 404.8 & 342.2 & $\mathrm{BDL}$ & 8.91 & 8.6 \\
\hline $18 \mathrm{H}-4,140-150$ & 151.30 & 7.08 & 1.34 & 569 & 497 & 23.1 & $\mathrm{BDL}$ & 818 & 1.75 & 14.88 & 28.4 & 29.8 & & 390.2 & D & 7.88 & 8.2 \\
\hline $19 \mathrm{H}$ & 159.30 & 7.52 & 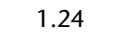 & 571 & 499 & 22.7 & $\mathrm{BL}$ & 85 & 1.77 & 11.74 & 28.7 & 29.2 & 404.5 & 404.2 & $\mathrm{BD}$ & 8.13 & 8.2 \\
\hline $20 \mathrm{H}-3,140-150$ & 168.80 & 7.24 & 1.01 & 569 & 498 & 22.2 & $\mathrm{BDL}$ & 800 & 1.76 & 17.08 & 28.9 & 28.4 & 396.7 & 417.8 & $\mathrm{BDL}$ & 8.84 & 7.9 \\
\hline
\end{tabular}

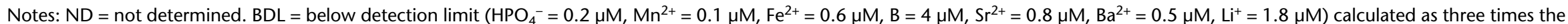
standard deviation of multiple measures of a blank. $\mathrm{H}_{4} \mathrm{SiO}_{4}$ values measured by different techniques during Expeditions 320 and 321 disagree significantly, especially for low values. Therefore, caution should be used concerning the $\mathrm{H}_{4} \mathrm{SiO}_{4}$ data and comparison between the different expeditions. 
Table T17. Carbon concentrations, Site U1336. (See table notes.) (Continued on next page.)

\begin{tabular}{|c|c|c|c|c|c|c|}
\hline \multirow{2}{*}{$\begin{array}{l}\text { Core, section, } \\
\text { interval }(\mathrm{cm})\end{array}$} & \multicolumn{2}{|c|}{ Depth $(m)$} & \multicolumn{4}{|c|}{ Carbon (wt\%) } \\
\hline & CSF & CCSF-A & $\mathrm{CaCO}_{3}$ & IC & $\mathrm{TC}$ & TOC \\
\hline \multicolumn{7}{|l|}{ 320-U1336A- } \\
\hline $1 \mathrm{H}-1,65-66$ & 0.65 & 0.91 & 76.5 & 9.2 & ND & ND \\
\hline $1 \mathrm{H}-2,65-66$ & 2.15 & 2.41 & 78.7 & 9.4 & ND & ND \\
\hline $1 \mathrm{H}-3,65-66$ & 3.65 & 3.91 & 92.2 & 11.1 & ND & ND \\
\hline $1 \mathrm{H}-4,65-66$ & 5.15 & 5.41 & 89.9 & 10.8 & ND & ND \\
\hline $1 \mathrm{H}-5,65-66$ & 6.65 & 6.91 & 89.8 & 10.8 & ND & ND \\
\hline $1 \mathrm{H}-6,25-26$ & 7.75 & 8.01 & 84.0 & 10.1 & ND & ND \\
\hline $2 \mathrm{H}-1,65-65$ & 8.65 & 10.16 & 80.6 & 9.7 & ND & ND \\
\hline $2 \mathrm{H}-2,65-66$ & 10.15 & 11.66 & 86.9 & 10.4 & ND & ND \\
\hline $2 \mathrm{H}-3,65-66$ & 11.65 & 13.16 & 78.4 & 9.4 & ND & ND \\
\hline $2 \mathrm{H}-4,65-66$ & 13.15 & 14.66 & 83.8 & 10.1 & ND & ND \\
\hline $2 \mathrm{H}-5,65-66$ & 14.65 & 16.16 & 87.5 & 10.5 & ND & ND \\
\hline $2 \mathrm{H}-6,65-66$ & 16.15 & 17.66 & 87.6 & 10.5 & ND & ND \\
\hline $2 \mathrm{H}-7,25-26$ & 17.25 & 18.76 & 88.0 & 10.6 & ND & ND \\
\hline $3 \mathrm{H}-2,65-66$ & 19.65 & 21.48 & 81.3 & 9.8 & ND & ND \\
\hline $3 \mathrm{H}-3,65-66$ & 21.15 & 22.98 & 92.0 & 11.0 & ND & ND \\
\hline $3 \mathrm{H}-4,65-66$ & 22.65 & 24.48 & 67.7 & 8.1 & ND & ND \\
\hline $3 \mathrm{H}-5,65-66$ & 24.15 & 25.98 & 83.6 & 10.0 & ND & ND \\
\hline $3 \mathrm{H}-6,65-66$ & 25.65 & 27.48 & 75.4 & 9.1 & ND & ND \\
\hline $3 \mathrm{H}-7,45-46$ & 26.95 & 28.78 & 82.0 & 9.8 & ND & ND \\
\hline $4 \mathrm{H}-2,65-66$ & 29.15 & 31.95 & 78.1 & 9.4 & ND & ND \\
\hline $4 \mathrm{H}-3,65-66$ & 30.65 & 33.45 & 89.2 & 10.7 & ND & ND \\
\hline $4 \mathrm{H}-4,65-66$ & 32.15 & 34.95 & 82.2 & 9.9 & ND & ND \\
\hline $4 \mathrm{H}-5,65-66$ & 33.65 & 36.45 & 72.3 & 8.7 & ND & ND \\
\hline $4 \mathrm{H}-6,45-46$ & 34.95 & 37.75 & 89.3 & 10.7 & ND & ND \\
\hline $4 \mathrm{H}-7,20-21$ & 35.51 & 38.31 & 71.8 & 8.6 & ND & ND \\
\hline $5 \mathrm{H}-1,65-66$ & 37.15 & 40.43 & 84.9 & 10.2 & ND & ND \\
\hline $5 \mathrm{H}-2,65-66$ & 38.65 & 41.93 & 85.9 & 10.3 & ND & ND \\
\hline $5 \mathrm{H}-3,65-66$ & 40.15 & 43.43 & 83.0 & 10.0 & ND & ND \\
\hline $5 \mathrm{H}-4,65-66$ & 41.65 & 44.93 & 81.9 & 9.8 & ND & ND \\
\hline $5 \mathrm{H}-5,65-66$ & 43.15 & 46.43 & 81.7 & 9.8 & ND & ND \\
\hline $5 \mathrm{H}-6,65-66$ & 44.65 & 47.93 & 84.2 & 10.1 & ND & ND \\
\hline $5 \mathrm{H}-7,40-41$ & 45.90 & 49.18 & 85.8 & 10.3 & ND & ND \\
\hline $6 \mathrm{H}-1,65-66$ & 46.65 & 53.29 & 80.3 & 9.6 & ND & ND \\
\hline $6 \mathrm{H}-2,65-66$ & 48.15 & 54.79 & 48.1 & 5.8 & ND & ND \\
\hline $6 \mathrm{H}-3,65-66$ & 49.65 & 56.29 & 71.4 & 8.6 & ND & ND \\
\hline $6 \mathrm{H}-4,65-66$ & 51.15 & 57.79 & 67.1 & 8.1 & ND & ND \\
\hline $6 \mathrm{H}-5,65-66$ & 52.65 & 59.29 & 76.7 & 9.2 & ND & ND \\
\hline $6 \mathrm{H}-6,65-66$ & 54.15 & 60.79 & 75.2 & 9.0 & ND & ND \\
\hline $7 \mathrm{H}-1,64-65$ & 56.14 & 64.18 & 85.5 & 10.3 & ND & ND \\
\hline $7 \mathrm{H}-2,64-65$ & 57.64 & 65.68 & 79.5 & 9.5 & ND & ND \\
\hline $7 \mathrm{H}-3,64-65$ & 59.14 & 67.18 & 84.0 & 10.1 & ND & ND \\
\hline $7 \mathrm{H}-4,64-65$ & 60.64 & 68.68 & 71.5 & 8.6 & ND & ND \\
\hline 7H-5, 64-65 & 62.14 & 70.18 & 80.7 & 9.7 & ND & ND \\
\hline $7 \mathrm{H}-6,64-65$ & 63.64 & 71.68 & 84.9 & 10.2 & ND & ND \\
\hline $7 \mathrm{H}-7,49-50$ & 64.99 & 73.03 & 84.4 & 10.1 & ND & ND \\
\hline $8 \mathrm{H}-1,65-66$ & 65.65 & 74.74 & 84.7 & 10.2 & ND & ND \\
\hline $8 \mathrm{H}-2,65-66$ & 67.15 & 76.24 & 85.3 & 10.2 & ND & ND \\
\hline $8 \mathrm{H}-3,65-66$ & 68.65 & 77.74 & 79.6 & 9.6 & ND & ND \\
\hline $8 \mathrm{H}-4,65-66$ & 70.15 & 79.24 & 85.1 & 10.2 & ND & ND \\
\hline $8 \mathrm{H}-5,65-66$ & 71.65 & 80.74 & 88.2 & 10.6 & ND & ND \\
\hline $8 \mathrm{H}-6,20-21$ & 72.70 & 81.79 & 86.6 & 10.4 & ND & ND \\
\hline $8 \mathrm{H}-7,65-66$ & 73.65 & 82.74 & 86.6 & 10.4 & ND & ND \\
\hline $9 \mathrm{H}-1,65-66$ & 75.15 & 84.92 & 90.9 & 10.9 & ND & ND \\
\hline $9 \mathrm{H}-2,62-63$ & 76.62 & 86.39 & 90.0 & 10.8 & ND & ND \\
\hline $9 \mathrm{H}-3,65-66$ & 78.15 & 87.92 & 87.8 & 10.5 & ND & ND \\
\hline $9 \mathrm{H}-4,65-66$ & 79.65 & 89.42 & 88.3 & 10.6 & ND & ND \\
\hline $9 \mathrm{H}-5,65-66$ & 81.15 & 90.92 & 86.5 & 10.4 & ND & ND \\
\hline $9 \mathrm{H}-6,65-66$ & 82.65 & 92.42 & 89.0 & 10.7 & ND & ND \\
\hline $9 \mathrm{H}-7,65-66$ & 84.15 & 93.92 & 88.0 & 10.6 & ND & ND \\
\hline $10 \mathrm{H}-1,89-90$ & 84.89 & 94.60 & 83.7 & 10.0 & ND & ND \\
\hline $10 \mathrm{H}-2,65-66$ & 86.15 & 95.86 & 86.8 & 10.4 & ND & ND \\
\hline $10 \mathrm{H}-3,65-66$ & 87.65 & 97.36 & 81.2 & 9.7 & ND & ND \\
\hline $10 \mathrm{H}-4,65-66$ & 89.15 & 98.86 & 90.1 & 10.8 & ND & ND \\
\hline $10 \mathrm{H}-5,65-66$ & 90.65 & 100.36 & 86.6 & 10.4 & ND & ND \\
\hline $10 \mathrm{H}-6,65-66$ & 92.15 & 101.86 & 84.5 & 10.1 & ND & ND \\
\hline $10 \mathrm{H}-7,50-51$ & 93.20 & 102.91 & 88.1 & 10.6 & ND & ND \\
\hline $11 \mathrm{H}-1,65-66$ & 94.15 & 105.94 & 91.1 & 10.9 & ND & ND \\
\hline
\end{tabular}

\begin{tabular}{|c|c|c|c|c|c|c|}
\hline \multirow{2}{*}{$\begin{array}{l}\text { Core, section, } \\
\text { interval }(\mathrm{cm})\end{array}$} & \multicolumn{2}{|c|}{ Depth $(m)$} & \multicolumn{4}{|c|}{ Carbon (wt\%) } \\
\hline & CSF & CCSF-A & $\mathrm{CaCO}_{3}$ & IC & TC & TOC \\
\hline $11 \mathrm{H}-2,65-66$ & 95.65 & 107.44 & 91.0 & 10.9 & ND & ND \\
\hline $11 \mathrm{H}-3,65-66$ & 97.15 & 108.94 & 85.3 & 10.2 & ND & ND \\
\hline $11 \mathrm{H}-4,65-66$ & 98.65 & 110.44 & 87.8 & 10.5 & ND & ND \\
\hline $11 \mathrm{H}-5,65-66$ & 100.15 & 111.94 & 88.5 & 10.6 & ND & ND \\
\hline $11 \mathrm{H}-6,65-66$ & 101.65 & 113.44 & 89.1 & 10.7 & ND & ND \\
\hline $11 \mathrm{H}-7,45-46$ & 102.95 & 114.74 & 90.1 & 10.8 & ND & ND \\
\hline $12 \mathrm{H}-2,65-66$ & 105.15 & 118.03 & 89.0 & 10.7 & ND & ND \\
\hline $12 \mathrm{H}-3,65-66$ & 106.65 & 119.53 & 91.3 & 11.0 & ND & ND \\
\hline $12 \mathrm{H}-4,65-66$ & 108.15 & 121.03 & 90.6 & 10.9 & ND & ND \\
\hline $12 \mathrm{H}-5,65-66$ & 109.65 & 122.53 & 88.2 & 10.6 & ND & ND \\
\hline $12 \mathrm{H}-6,55-56$ & 111.05 & 123.93 & 90.7 & 10.9 & ND & ND \\
\hline $12 \mathrm{H}-7,45-46$ & 111.95 & 124.83 & 92.0 & 11.0 & ND & ND \\
\hline $13 \mathrm{H}-2,65-66$ & 114.65 & 128.87 & 90.3 & 10.8 & ND & ND \\
\hline $13 \mathrm{H}-3,65-66$ & 116.15 & 130.37 & 88.5 & 10.6 & ND & ND \\
\hline $13 \mathrm{H}-4,65-66$ & 117.65 & 131.87 & 89.9 & 10.8 & ND & ND \\
\hline $13 \mathrm{H}-5,65-66$ & 119.15 & 133.37 & 87.2 & 10.5 & ND & ND \\
\hline $13 \mathrm{H}-6,65-66$ & 120.65 & 134.87 & 79.7 & 9.6 & ND & ND \\
\hline $13 \mathrm{H}-7,35-36$ & 121.85 & 136.07 & 91.6 & 11.0 & ND & ND \\
\hline $15 \mathrm{H}-1,65-66$ & 124.15 & 140.38 & 89.5 & 10.7 & ND & ND \\
\hline $15 \mathrm{H}-2,65-66$ & 125.65 & 141.88 & 87.3 & 10.5 & ND & ND \\
\hline $15 \mathrm{H}-3,65-66$ & 127.15 & 143.38 & 89.0 & 10.7 & ND & ND \\
\hline $15 \mathrm{H}-4,65-66$ & 128.65 & 144.88 & 88.0 & 10.6 & ND & ND \\
\hline $15 \mathrm{H}-5,65-66$ & 130.15 & 146.38 & 91.0 & 10.9 & ND & ND \\
\hline $15 \mathrm{H}-6,65-66$ & 131.65 & 147.88 & 83.7 & 10.0 & ND & ND \\
\hline $15 \mathrm{H}-7,40-41$ & 132.90 & 149.13 & 88.3 & 10.6 & ND & ND \\
\hline $16 \mathrm{H}-1,121-122$ & 134.21 & 155.71 & 87.8 & 10.5 & ND & ND \\
\hline $16 \mathrm{H}-2,65-66$ & 135.15 & 156.65 & 89.7 & 10.8 & ND & ND \\
\hline $16 \mathrm{H}-3,65-65$ & 136.65 & 158.15 & 83.2 & 10.0 & ND & ND \\
\hline $16 \mathrm{H}-4,65-65$ & 138.15 & 159.65 & 88.9 & 10.7 & ND & ND \\
\hline $16 \mathrm{H}-5,110-111$ & 140.10 & 161.60 & 90.3 & 10.8 & ND & ND \\
\hline $16 \mathrm{H}-6,65-65$ & 141.15 & 162.65 & 90.0 & 10.8 & ND & ND \\
\hline $17 \mathrm{H}-1,65-66$ & 142.65 & 166.06 & 89.0 & 10.7 & ND & ND \\
\hline $17 \mathrm{H}-2,65-66$ & 144.15 & 167.56 & 90.2 & 10.8 & ND & ND \\
\hline $17 \mathrm{H}-3,65-66$ & 145.65 & 169.06 & 80.9 & 9.7 & ND & ND \\
\hline $17 \mathrm{H}-4,65-66$ & 147.15 & 170.56 & 89.0 & 10.7 & ND & ND \\
\hline $17 \mathrm{H}-5,65-66$ & 148.65 & 172.06 & 86.6 & 10.4 & ND & ND \\
\hline $17 \mathrm{H}-6,65-66$ & 150.15 & 173.56 & 87.2 & 10.5 & ND & ND \\
\hline $17 \mathrm{H}-7,40-41$ & 151.40 & 174.81 & 85.4 & 10.2 & ND & ND \\
\hline $18 \mathrm{H}-1,65-66$ & 152.15 & 175.56 & 76.8 & 9.2 & ND & ND \\
\hline $18 \mathrm{H}-2,65-66$ & 153.65 & 177.06 & 82.9 & 9.9 & ND & ND \\
\hline $18 \mathrm{H}-3,65-66$ & 155.15 & 178.56 & 86.5 & 10.4 & ND & ND \\
\hline $18 \mathrm{H}-4,65-66$ & 156.65 & 180.06 & 88.5 & 10.6 & ND & ND \\
\hline $18 \mathrm{H}-5,65-66$ & 158.15 & 181.56 & 89.7 & 10.8 & ND & ND \\
\hline $18 \mathrm{H}-6,65-66$ & 159.65 & 183.06 & 83.7 & 10.0 & ND & ND \\
\hline $18 \mathrm{H}-7,50-51$ & 161.00 & 184.41 & 83.9 & 10.1 & ND & ND \\
\hline $19 \mathrm{H}-1,65-66$ & 161.65 & 185.06 & 87.1 & 10.5 & ND & ND \\
\hline $19 \mathrm{H}-2,65-66$ & 163.15 & 186.56 & 86.4 & 10.4 & ND & ND \\
\hline $19 \mathrm{H}-3,65-66$ & 164.65 & 188.06 & 88.8 & 10.7 & ND & ND \\
\hline $19 \mathrm{H}-4,65-66$ & 166.15 & 189.56 & 88.7 & 10.6 & ND & ND \\
\hline $19 \mathrm{H}-5,65-66$ & 167.65 & 191.06 & 84.7 & 10.2 & ND & ND \\
\hline $19 \mathrm{H}-6,65-66$ & 169.15 & 192.56 & 88.2 & 10.6 & ND & ND \\
\hline $19 \mathrm{H}-7,20-21$ & 170.20 & 193.61 & 89.1 & 10.7 & ND & ND \\
\hline $20 \mathrm{H}-1,64-65$ & 171.14 & 194.55 & 88.2 & 10.6 & ND & ND \\
\hline $20 \mathrm{H}-2,64-65$ & 172.64 & 196.05 & 87.4 & 10.5 & ND & ND \\
\hline $20 \mathrm{H}-3,64-65$ & 174.14 & 197.55 & 86.5 & 10.4 & ND & ND \\
\hline $20 \mathrm{H}-4,64-65$ & 175.64 & 199.05 & 88.3 & 10.6 & ND & ND \\
\hline $20 \mathrm{H}-5,64-65$ & 177.14 & 200.55 & 90.7 & 10.9 & ND & ND \\
\hline $20 \mathrm{H}-6,64-65$ & 178.64 & 202.05 & 90.2 & 10.8 & ND & ND \\
\hline $21 \mathrm{H}-1,65-66$ & 180.65 & 204.06 & 90.8 & 10.9 & ND & ND \\
\hline $21 \mathrm{H}-2,65-66$ & 182.15 & 205.56 & 88.7 & 10.6 & ND & ND \\
\hline $21 \mathrm{H}-3,65-66$ & 183.65 & 207.06 & 90.5 & 10.9 & ND & ND \\
\hline $21 \mathrm{H}-4,25-26$ & 184.25 & 207.66 & 93.0 & 11.2 & ND & ND \\
\hline $22 X-1,65-66$ & 185.45 & 208.86 & 89.7 & 10.8 & ND & ND \\
\hline $22 X-2,65-66$ & 186.95 & 210.36 & 91.2 & 11.0 & ND & ND \\
\hline $22 X-3,60-61$ & 188.40 & 211.81 & 89.0 & 10.7 & ND & ND \\
\hline $22 X-4,65-66$ & 189.95 & 213.36 & 91.1 & 10.9 & ND & ND \\
\hline $22 X-5,65-66$ & 191.45 & 214.86 & 90.9 & 10.9 & ND & ND \\
\hline $2 X-6,4-5$ & 192.14 & 215.55 & 92.4 & 11.1 & ND & D \\
\hline
\end{tabular}


Table T17 (continued).

\begin{tabular}{|c|c|c|c|c|c|c|}
\hline \multirow{2}{*}{$\begin{array}{l}\text { Core, section, } \\
\text { interval }(\mathrm{cm})\end{array}$} & \multicolumn{2}{|c|}{ Depth (m) } & \multicolumn{4}{|c|}{ Carbon (wt\%) } \\
\hline & CSF & CCSF-A & $\mathrm{CaCO}_{3}$ & IC & $\mathrm{TC}$ & TOC \\
\hline $23 X-1,58-59$ & 194.98 & 218.39 & 92.2 & 11.1 & ND & ND \\
\hline $23 X-2,59-60$ & 196.49 & 219.90 & 91.1 & 10.9 & ND & ND \\
\hline $23 X-3,59-60$ & 197.99 & 221.40 & 91.2 & 10.9 & ND & ND \\
\hline $23 X-4,58-60$ & 199.48 & 222.89 & 91.2 & 11.0 & ND & ND \\
\hline $23 X-5,60-61$ & 201.00 & 224.41 & 90.2 & 10.8 & ND & ND \\
\hline $24 X-1,62-63$ & 203.02 & 226.43 & 93.1 & 11.2 & ND & ND \\
\hline $24 \mathrm{X}-2,54-55$ & 204.44 & 227.85 & 92.1 & 11.1 & ND & ND \\
\hline $24 X-3,72-73$ & 206.12 & 229.53 & 94.3 & 11.3 & ND & ND \\
\hline $24 X-4,56-57$ & 207.46 & 230.87 & 92.4 & 11.1 & ND & ND \\
\hline $24 X-5,54-55$ & 208.94 & 232.35 & 91.0 & 10.9 & ND & ND \\
\hline $25 X-1,60-61$ & 212.60 & 236.01 & 91.8 & 11.0 & ND & ND \\
\hline $25 X-2,60-61$ & 214.10 & 237.51 & 90.7 & 10.9 & ND & ND \\
\hline $25 X-3,60-61$ & 215.60 & 239.01 & 87.5 & 10.5 & ND & ND \\
\hline $26 \mathrm{X}-1,62-63$ & 222.22 & 245.63 & 91.8 & 11.0 & ND & ND \\
\hline $26 \mathrm{X}-2,61-62$ & 223.71 & 247.12 & 92.5 & 11.1 & ND & ND \\
\hline $26 \mathrm{X}-3,60-61$ & 225.20 & 248.61 & 92.0 & 11.0 & ND & ND \\
\hline $26 X-4,72-73$ & 226.82 & 250.23 & 93.0 & 11.2 & ND & ND \\
\hline $26 X-5,68-69$ & 228.28 & 251.69 & 91.8 & 11.0 & ND & ND \\
\hline $26 \mathrm{X}-6,64-65$ & 229.74 & 253.15 & 89.1 & 10.7 & ND & ND \\
\hline $27 X-1,59-60$ & 231.79 & 255.20 & 92.2 & 11.1 & ND & ND \\
\hline $27 X-2,61-62$ & 233.31 & 256.72 & 92.2 & 11.1 & ND & ND \\
\hline $27 X-3,59-60$ & 234.79 & 258.20 & 92.7 & 11.1 & ND & ND \\
\hline $27 X-4,58-59$ & 236.28 & 259.69 & 92.6 & 11.1 & ND & ND \\
\hline $27 X-5,18-19$ & 237.18 & 260.59 & 92.6 & 11.1 & ND & ND \\
\hline $28 \mathrm{X}-1,42-43$ & 241.22 & 264.63 & 91.7 & 11.0 & ND & ND \\
\hline $28 \mathrm{X}-2,30-31$ & 242.60 & 266.01 & 93.0 & 11.2 & ND & ND \\
\hline $29 X-1,54-55$ & 250.94 & 274.35 & 92.5 & 11.1 & ND & ND \\
\hline $29 X-2,66-67$ & 252.56 & 275.97 & 93.2 & 11.2 & ND & ND \\
\hline $29 X-3,57-58$ & 253.97 & 277.38 & 92.5 & 11.1 & ND & ND \\
\hline $30 X-1,62-63$ & 260.62 & 284.03 & 91.7 & 11.0 & ND & ND \\
\hline $30 X-2,64-65$ & 262.14 & 285.55 & 92.8 & 11.1 & ND & ND \\
\hline $30 X-3,45-46$ & 263.45 & 286.86 & 92.0 & 11.0 & ND & ND \\
\hline $31 X-1,55-55$ & 270.15 & 293.56 & 92.7 & 11.1 & ND & ND \\
\hline $31 X-2,60-61$ & 271.70 & 295.11 & 92.0 & 11.0 & ND & ND \\
\hline $31 X-3,42-43$ & 273.02 & 296.43 & 93.1 & 11.2 & ND & ND \\
\hline $32 X-1,62-63$ & 279.82 & 303.23 & 92.1 & 11.1 & ND & ND \\
\hline $32 X-2,54-55$ & 281.24 & 304.65 & 91.3 & 11.0 & ND & ND \\
\hline $32 X-3,32-33$ & 282.52 & 305.93 & 89.4 & 10.7 & ND & ND \\
\hline $33 X-2,47-48$ & 289.42 & 312.83 & 89.3 & 10.7 & ND & ND \\
\hline $35 X-1,74-75$ & 299.04 & 322.45 & 90.0 & 10.8 & ND & ND \\
\hline
\end{tabular}

\begin{tabular}{|c|c|c|c|c|c|c|}
\hline \multirow{2}{*}{$\begin{array}{l}\text { Core, section, } \\
\text { interval }(\mathrm{cm})\end{array}$} & \multicolumn{2}{|c|}{ Depth (m) } & \multicolumn{4}{|c|}{ Carbon (wt\%) } \\
\hline & CSF & CCSF-A & $\mathrm{CaCO}_{3}$ & IC & TC & TOC \\
\hline \multicolumn{7}{|l|}{ 320-U1336B- } \\
\hline $1 \mathrm{H}-1,71-72$ & 0.71 & 0.71 & 78.6 & 9.4 & 9.49 & 0.18 \\
\hline $2 \mathrm{H}-2,72-73$ & 4.02 & 4.55 & 94.4 & 11.3 & 11.33 & 0.07 \\
\hline $2 \mathrm{H}-6,72-73$ & 10.02 & 10.55 & 74.6 & 9.0 & ND & ND \\
\hline $3 \mathrm{H}-2,72-73$ & 13.52 & 16.08 & 91.1 & 10.9 & 10.93 & 0.08 \\
\hline $3 \mathrm{H}-6,72-73$ & 19.52 & 22.08 & 86.0 & 10.3 & ND & ND \\
\hline $4 \mathrm{H}-2,72-73$ & 23.02 & 27.20 & 89.5 & 10.7 & 10.70 & 0.08 \\
\hline $4 \mathrm{H}-6,72-73$ & 29.02 & 33.20 & 90.7 & 10.9 & ND & ND \\
\hline $5 \mathrm{H}-2,72-73$ & 32.52 & 38.10 & 84.6 & 10.2 & 10.16 & 0.08 \\
\hline $5 \mathrm{H}-6,72-73$ & 38.52 & 44.10 & 79.8 & 9.6 & ND & ND \\
\hline $6 \mathrm{H}-2,72-73$ & 42.02 & 49.55 & 88.6 & 10.6 & 10.63 & 0.05 \\
\hline $6 \mathrm{H}-6,72-73$ & 48.02 & 55.55 & 80.6 & 9.7 & ND & ND \\
\hline $7 \mathrm{H}-2,72-73$ & 51.52 & 60.21 & 85.4 & 10.3 & 10.22 & 0.10 \\
\hline $7 \mathrm{H}-4,72-73$ & 54.52 & 63.21 & 89.2 & 10.7 & ND & ND \\
\hline $7 \mathrm{H}-6,72-73$ & 57.52 & 66.21 & 82.4 & 9.9 & ND & ND \\
\hline $8 \mathrm{H}-2,72-73$ & 61.02 & 69.90 & 77.7 & 9.3 & 9.36 & 0.05 \\
\hline $8 \mathrm{H}-6,72-73$ & 67.02 & 75.90 & 82.7 & 9.9 & ND & ND \\
\hline $9 \mathrm{H}-2,72-73$ & 70.52 & 79.33 & 86.7 & 10.4 & 10.35 & 0.06 \\
\hline $9 \mathrm{H}-6,72-73$ & 76.52 & 85.33 & 92.6 & 11.1 & ND & ND \\
\hline $10 \mathrm{H}-2,72-73$ & 80.02 & 90.21 & 90.5 & 10.9 & 10.83 & 0.05 \\
\hline $10 \mathrm{H}-6,72-73$ & 86.02 & 96.21 & 86.5 & 10.4 & ND & ND \\
\hline $11 \mathrm{H}-2,71-72$ & 89.51 & 100.20 & 91.9 & 11.0 & 10.99 & 0.05 \\
\hline $11 \mathrm{H}-6,83-84$ & 95.63 & 106.32 & 93.8 & 11.3 & ND & ND \\
\hline $12 \mathrm{H}-2,71-72$ & 99.01 & 111.52 & 88.0 & 10.6 & 10.55 & 0.05 \\
\hline $12 \mathrm{H}-6,71-72$ & 105.01 & 117.52 & 94.0 & 11.3 & ND & ND \\
\hline $13 \mathrm{H}-2,71-72$ & 108.51 & 122.77 & 94.0 & 11.3 & 11.21 & 0.14 \\
\hline $13 \mathrm{H}-6,71-72$ & 114.51 & 128.77 & 94.2 & 11.3 & ND & ND \\
\hline $14 \mathrm{H}-2,72-73$ & 118.02 & 135.00 & 87.1 & 10.5 & 10.42 & 0.30 \\
\hline $14 \mathrm{H}-4,70-71$ & 121.00 & 137.98 & 95.9 & 11.5 & ND & ND \\
\hline $15 \mathrm{H}-2,72-73$ & 127.52 & 145.31 & 92.9 & 11.2 & 11.09 & 0.17 \\
\hline $15 \mathrm{H}-6,72-73$ & 133.52 & 151.31 & 93.4 & 11.2 & ND & ND \\
\hline $16 \mathrm{H}-1,42-43$ & 135.22 & 153.01 & 94.1 & 11.3 & 11.24 & 0.15 \\
\hline $17 \mathrm{H}-2,72-73$ & 139.02 & 156.81 & 92.0 & 11.0 & 10.98 & 0.07 \\
\hline $17 \mathrm{H}-6,34-35$ & 144.14 & 161.93 & 91.1 & 10.9 & ND & ND \\
\hline $18 \mathrm{H}-2,71-72$ & 147.61 & 165.40 & 90.4 & 10.9 & 10.79 & 0.07 \\
\hline $18 \mathrm{H}-6,71-72$ & 153.61 & 171.40 & 84.8 & 10.2 & ND & ND \\
\hline $19 \mathrm{H}-2,71-72$ & 157.11 & 174.90 & 84.9 & 10.2 & 10.23 & 0.06 \\
\hline $19 \mathrm{H}-6,71-72$ & 163.11 & 180.90 & 90.6 & 10.9 & ND & ND \\
\hline $20 \mathrm{H}-2,71-72$ & 166.61 & 184.40 & 89.5 & 10.8 & 10.74 & 0.06 \\
\hline $20 \mathrm{H}-6,71-72$ & 172.61 & 190.40 & 92.8 & 11.1 & ND & ND \\
\hline
\end{tabular}

Notes: IC = inorganic carbon, $\mathrm{TC}=$ total carbon, $\mathrm{TOC}=$ total organic carbon determined by acidification method. ND = not determined. 
Table T18. Inorganic geochemistry of solid samples, Hole U1336B. (See table notes.)

\begin{tabular}{|c|c|c|c|c|c|c|c|c|c|c|c|c|c|c|c|}
\hline \multirow{2}{*}{$\begin{array}{l}\text { Core, section, } \\
\text { interval }(\mathrm{cm})\end{array}$} & \multicolumn{2}{|c|}{ Depth $(m)$} & \multicolumn{10}{|c|}{ Major element oxide (wt\%) } & \multicolumn{3}{|c|}{ Trace element (ppm) } \\
\hline & CSF & CCSF-A & $\mathrm{SiO}_{2}$ & $\mathrm{Al}_{2} \mathrm{O}_{3}$ & $\mathrm{Fe}_{2} \mathrm{O}_{3} \mathrm{~T}$ & $\mathrm{MnO}$ & $\mathrm{MgO}$ & $\mathrm{CaO}$ & $\mathrm{Na}_{2} \mathrm{O}$ & $\mathrm{K}_{2} \mathrm{O}$ & $\mathrm{TiO}_{2}$ & $\mathrm{P}_{2} \mathrm{O}_{5}$ & $\mathrm{Ba}$ & $\mathrm{Sr}$ & $\mathrm{Zr}$ \\
\hline \multicolumn{16}{|l|}{ 320-U1336B- } \\
\hline $1 \mathrm{H}-1,71-72$ & 0.71 & 0.71 & 8.93 & 1.495 & 1.248 & 0.312 & 0.768 & 43.5 & 1.833 & 0.302 & 0.0300 & 0.389 & 2143 & 1190 & 29.22 \\
\hline $2 \mathrm{H}-6,72-73$ & 10.02 & 10.55 & 11.78 & 1.601 & 1.783 & 0.202 & 0.847 & 41.6 & 1.735 & 0.320 & 0.0359 & 0.308 & 2466 & 1220 & 31.62 \\
\hline $3 \mathrm{H}-6,72-73$ & 19.52 & 22.08 & 5.81 & 0.814 & 1.109 & 0.160 & 0.587 & 46.7 & 1.279 & 0.176 & BDL & 0.175 & 1475 & 1246 & 19.81 \\
\hline $4 \mathrm{H}-6,72-73$ & 29.02 & 33.20 & 3.74 & 0.221 & 0.454 & 0.101 & 0.397 & 49.2 & 0.917 & 0.059 & $\mathrm{BDL}$ & 0.114 & 839 & 1072 & 8.50 \\
\hline $5 \mathrm{H}-6,72-73$ & 38.52 & 44.10 & 9.88 & 0.941 & 1.322 & 0.192 & 0.647 & 43.8 & 1.515 & 0.206 & 0.0063 & 0.191 & 1996 & 980 & 19.10 \\
\hline $6 \mathrm{H}-6,72-73$ & 48.02 & 55.55 & 9.97 & 0.974 & 1.076 & 0.131 & 0.548 & 43.5 & 1.382 & 0.223 & 0.0089 & 0.169 & 1546 & 1092 & 15.98 \\
\hline $7 \mathrm{H}-6,72-73$ & 57.52 & 66.21 & 8.85 & 0.772 & 1.312 & 0.193 & 0.583 & 45.0 & 1.332 & 0.172 & $\mathrm{BDL}$ & 0.201 & 1951 & 1146 & 15.70 \\
\hline $9 \mathrm{H}-6,72-73$ & 76.52 & 85.33 & 2.94 & 0.000 & 0.257 & 0.088 & 0.317 & 49.6 & 0.861 & 0.011 & BDL & 0.102 & 565 & 1018 & 6.30 \\
\hline $10 \mathrm{H}-6,72-73$ & 86.02 & 96.21 & 6.63 & 0.458 & 0.869 & 0.104 & 0.494 & 47.2 & 1.115 & 0.092 & BDL & 0.167 & 1567 & 1168 & 10.40 \\
\hline $11 \mathrm{H}-6,83-84$ & 95.63 & 106.32 & 2.68 & 0.023 & 0.156 & 0.089 & 0.253 & 50.9 & 0.655 & 0.016 & BDL & 0.108 & 708 & 1052 & 6.67 \\
\hline $12 \mathrm{H}-6,71-72$ & 105.01 & 117.52 & 2.14 & 0.031 & 0.131 & 0.081 & 0.241 & 50.1 & 0.717 & 0.022 & $\mathrm{BDL}$ & 0.105 & 692 & 1148 & 2.88 \\
\hline $13 \mathrm{H}-6,71-72$ & 114.51 & 128.77 & 2.29 & 0.044 & 0.153 & 0.088 & 0.225 & 51.1 & 0.582 & 0.014 & BDL & 0.125 & 787 & 1094 & 5.33 \\
\hline $14 \mathrm{H}-4,70-71$ & 121.00 & 137.98 & 1.12 & 0.013 & 0.012 & 0.075 & 0.189 & 52.1 & 0.323 & 0.000 & BDL & 0.114 & 824 & 904 & 2.88 \\
\hline $15 \mathrm{H}-6,72-73$ & 133.52 & 151.31 & 2.73 & 0.098 & 0.181 & 0.093 & 0.207 & 49.5 & 0.604 & 0.023 & $\mathrm{BDL}$ & 0.101 & 915 & 1066 & 7.12 \\
\hline $16 \mathrm{H}-1,42-43$ & 135.22 & 153.01 & 1.79 & 0.142 & 0.147 & 0.075 & 0.198 & 49.9 & 0.553 & 0.038 & $\mathrm{BDL}$ & 0.139 & 1365 & 997 & 6.89 \\
\hline $17 \mathrm{H}-6,34-35$ & 144.14 & 161.93 & 4.57 & 0.228 & 0.427 & 0.070 & 0.239 & 49.7 & 0.632 & 0.046 & $\mathrm{BDL}$ & 0.120 & 1366 & 1152 & 8.50 \\
\hline $18 \mathrm{H}-6,71-72$ & 153.61 & 171.40 & 8.94 & 0.474 & 0.615 & 0.077 & 0.300 & 44.7 & 0.818 & 0.093 & $\mathrm{BDL}$ & 0.152 & 2138 & 1152 & 11.59 \\
\hline $19 \mathrm{H}-6,71-72$ & 163.11 & 180.90 & 4.89 & 0.222 & 0.344 & 0.073 & 0.222 & 48.2 & 0.613 & 0.042 & BDL & 0.126 & 1398 & 1147 & 7.64 \\
\hline $20 \mathrm{H}-6,71-72$ & 172.61 & 190.40 & 3.46 & 0.169 & 0.334 & 0.072 & 0.209 & 49.1 & 0.541 & 0.029 & BDL & 0.095 & 1384 & 1168 & 8.07 \\
\hline
\end{tabular}

Notes: $\mathrm{BDL}=$ below detection limit $\left(\mathrm{Al}_{2} \mathrm{O}_{3}=0.003 \mathrm{wt} \%, \mathrm{~K}_{2} \mathrm{O}=0.007 \mathrm{wt} \%, \mathrm{TiO}_{2}=0.0014 \mathrm{wt} \%\right)$. Values for $\mathrm{Sr}$ and $\mathrm{Ba}$ are well above the calibration range $(\mathrm{Sr}<700 \mathrm{ppm}, \mathrm{Ba}<570 \mathrm{ppm}) . \mathrm{H}_{4} \mathrm{SiO}_{4}$ values measured by different techniques during Expeditions 320 and 321 disagree significantly, especially for low values. Therefore, caution should be used concerning the $\mathrm{H}_{4} \mathrm{SiO}_{4}$ data and comparison between the different expeditions. See "Geochemistry" in the "Methods" chapter for uncertainty estimates and assessment of accuracy. 
Table T19. Moisture and density measurements, Site U1336. (Continued on next page.)

\begin{tabular}{|c|c|c|c|c|c|c|}
\hline \multirow[b]{2}{*}{$\begin{array}{l}\text { Core, section, } \\
\text { interval }(\mathrm{cm})\end{array}$} & \multirow[b]{2}{*}{$\begin{array}{l}\text { Depth } \\
\operatorname{CSF}(\mathrm{m})\end{array}$} & \multirow{2}{*}{$\begin{array}{l}\text { Water } \\
\text { content } \\
\text { (wt\%) }\end{array}$} & \multicolumn{3}{|c|}{ Density $\left(\mathrm{g} / \mathrm{cm}^{3}\right)$} & \multirow[b]{2}{*}{$\begin{array}{l}\text { Porosity } \\
\text { (\%) }\end{array}$} \\
\hline & & & $\begin{array}{l}\text { Wet } \\
\text { bulk }\end{array}$ & $\begin{array}{l}\text { Dry } \\
\text { bulk }\end{array}$ & Grain & \\
\hline \multicolumn{7}{|l|}{ 320-U1336A- } \\
\hline $1 \mathrm{H}-1,75-76$ & 0.75 & 59.0 & 1.40 & 0.58 & 3.00 & 80.8 \\
\hline $1 \mathrm{H}-2,75-76$ & 2.25 & 48.5 & 1.54 & 0.80 & 2.95 & 73.1 \\
\hline $1 \mathrm{H}-3,75-76$ & 3.75 & 38.4 & 1.70 & 1.05 & 2.89 & 63.8 \\
\hline $1 \mathrm{H}-4,75-76$ & 5.25 & 39.6 & 1.68 & 1.02 & 2.91 & 65.1 \\
\hline $1 \mathrm{H}-5,75-76$ & 6.75 & 40.0 & 1.67 & 1.00 & 2.88 & 65.2 \\
\hline $1 \mathrm{H}-6,35-36$ & 7.85 & 46.7 & 1.56 & 0.83 & 2.86 & 71.0 \\
\hline $2 \mathrm{H}-1,75-76$ & 8.75 & 50.5 & 1.51 & 0.75 & 2.90 & 74.3 \\
\hline $2 \mathrm{H}-2,75-76$ & 10.25 & 44.5 & 1.59 & 0.88 & 2.87 & 69.2 \\
\hline $2 \mathrm{H}-3,75-76$ & 11.75 & 50.6 & 1.50 & 0.74 & 2.87 & 74.1 \\
\hline $2 \mathrm{H}-4,75-76$ & 13.25 & 45.9 & 1.55 & 0.84 & 2.77 & 69.6 \\
\hline $2 \mathrm{H}-5,75-76$ & 14.75 & 43.9 & 1.58 & 0.89 & 2.76 & 67.8 \\
\hline $2 \mathrm{H}-6,75-76$ & 16.25 & 44.2 & 1.57 & 0.88 & 2.73 & 67.9 \\
\hline $2 \mathrm{H}-7,35-36$ & 17.35 & 43.4 & 1.62 & 0.92 & 2.94 & 68.7 \\
\hline $3 \mathrm{H}-2,75-76$ & 19.75 & 46.5 & 1.56 & 0.83 & 2.86 & 70.8 \\
\hline $3 \mathrm{H}-3,75-76$ & 21.25 & 52.7 & 1.48 & 0.70 & 2.91 & 76.0 \\
\hline $3 \mathrm{H}-4,75-76$ & 22.75 & 52.1 & 1.48 & 0.71 & 2.88 & 75.4 \\
\hline $3 \mathrm{H}-5,75-76$ & 24.25 & 44.2 & 1.58 & 0.88 & 2.78 & 68.2 \\
\hline $3 \mathrm{H}-6,75-76$ & 25.75 & 48.7 & 1.51 & 0.78 & 2.77 & 71.9 \\
\hline $3 \mathrm{H}-7,55-56$ & 27.05 & 46.1 & 1.57 & 0.85 & 2.89 & 70.7 \\
\hline $4 \mathrm{H}-2,75-76$ & 29.25 & 48.8 & 1.56 & 0.80 & 3.08 & 74.1 \\
\hline $4 \mathrm{H}-3,75-76$ & 30.75 & 39.6 & 1.65 & 1.00 & 2.76 & 63.8 \\
\hline $4 \mathrm{H}-4,75-76$ & 32.25 & 45.0 & 1.58 & 0.87 & 2.87 & 69.6 \\
\hline $4 \mathrm{H}-5,75-76$ & 33.75 & 54.0 & 1.45 & 0.67 & 2.83 & 76.4 \\
\hline $4 \mathrm{H}-6,55-56$ & 35.05 & 42.1 & 1.62 & 0.94 & 2.81 & 66.6 \\
\hline $4 \mathrm{H}-7,30-31$ & 35.61 & 49.6 & 1.50 & 0.76 & 2.79 & 72.8 \\
\hline $5 \mathrm{H}-1,75-76$ & 37.25 & 48.9 & 1.50 & 0.77 & 2.72 & 71.8 \\
\hline $5 \mathrm{H}-2,75-76$ & 38.75 & 47.4 & 1.54 & 0.81 & 2.81 & 71.2 \\
\hline $5 \mathrm{H}-3,75-76$ & 40.25 & 49.6 & 1.50 & 0.76 & 2.79 & 72.8 \\
\hline $5 \mathrm{H}-4,75-76$ & 41.75 & 48.3 & 1.52 & 0.78 & 2.76 & 71.6 \\
\hline $5 \mathrm{H}-5,75-76$ & 43.25 & 50.0 & 1.49 & 0.74 & 2.73 & 72.7 \\
\hline $5 \mathrm{H}-6,75-76$ & 44.75 & 48.3 & 1.53 & 0.79 & 2.87 & 72.4 \\
\hline $5 \mathrm{H}-7,50-51$ & 46.00 & 47.4 & 1.55 & 0.82 & 2.90 & 71.9 \\
\hline $6 \mathrm{H}-1,75-76$ & 46.75 & 46.5 & 1.54 & 0.83 & 2.77 & 70.1 \\
\hline $6 \mathrm{H}-2,75-76$ & 48.25 & 58.5 & 1.38 & 0.57 & 2.72 & 78.9 \\
\hline $6 \mathrm{H}-3,75-76$ & 49.75 & 50.6 & 1.49 & 0.74 & 2.79 & 73.6 \\
\hline $6 \mathrm{H}-4,75-76$ & 51.25 & 48.6 & 1.52 & 0.78 & 2.81 & 72.2 \\
\hline $6 \mathrm{H}-5,75-76$ & 52.75 & 50.6 & 1.51 & 0.75 & 2.94 & 74.6 \\
\hline $6 \mathrm{H}-6,75-76$ & 54.25 & 45.4 & 1.56 & 0.85 & 2.74 & 69.0 \\
\hline 7H-1, 75-76 & 56.25 & 46.3 & 1.56 & 0.84 & 2.85 & 70.6 \\
\hline 7H-2, 75-76 & 57.75 & 48.7 & 1.51 & 0.78 & 2.78 & 72.0 \\
\hline 7H-3, 75-76 & 59.25 & 44.9 & 1.57 & 0.87 & 2.80 & 69.0 \\
\hline 7H-4, 75-76 & 60.75 & 45.0 & 1.56 & 0.86 & 2.73 & 68.6 \\
\hline 7H-5, 75-76 & 62.25 & 45.3 & 1.57 & 0.86 & 2.82 & 69.5 \\
\hline 7H-6, 75-76 & 63.75 & 44.3 & 1.59 & 0.89 & 2.85 & 68.8 \\
\hline 7H-7, 60-61 & 65.10 & 44.7 & 1.59 & 0.88 & 2.86 & 69.3 \\
\hline $8 \mathrm{H}-1,75-76$ & 65.75 & 48.1 & 1.53 & 0.80 & 2.83 & 71.9 \\
\hline $8 \mathrm{H}-2,75-76$ & 67.25 & 43.8 & 1.60 & 0.90 & 2.84 & 68.4 \\
\hline $8 \mathrm{H}-3,75-76$ & 68.75 & 45.4 & 1.56 & 0.85 & 2.75 & 69.1 \\
\hline $8 \mathrm{H}-4,75-76$ & 70.25 & 41.4 & 1.64 & 0.96 & 2.83 & 66.1 \\
\hline $8 \mathrm{H}-5,75-76$ & 71.75 & 42.1 & 1.61 & 0.93 & 2.75 & 66.1 \\
\hline $8 \mathrm{H}-6,30-31$ & 72.80 & 39.9 & 1.65 & 0.99 & 2.77 & 64.3 \\
\hline $8 \mathrm{H}-7,75-76$ & 73.75 & 42.5 & 1.62 & 0.93 & 2.82 & 67.1 \\
\hline $9 \mathrm{H}-1,75-76$ & 75.25 & 40.3 & 1.65 & 0.98 & 2.79 & 64.7 \\
\hline $9 \mathrm{H}-2,72-73$ & 76.72 & 42.3 & 1.62 & 0.93 & 2.80 & 66.7 \\
\hline $9 \mathrm{H}-3,75-76$ & 78.25 & 42.4 & 1.61 & 0.93 & 2.80 & 66.8 \\
\hline $9 \mathrm{H}-4,75-76$ & 79.75 & 42.3 & 1.62 & 0.94 & 2.83 & 67.0 \\
\hline $9 \mathrm{H}-5,75-76$ & 81.25 & 49.8 & 1.41 & 0.71 & 2.26 & 68.7 \\
\hline $9 \mathrm{H}-6,75-76$ & 82.75 & 41.3 & 1.64 & 0.97 & 2.87 & 66.4 \\
\hline $9 \mathrm{H}-7,75-76$ & 84.25 & 41.9 & 1.60 & 0.93 & 2.71 & 65.6 \\
\hline $10 \mathrm{H}-1,75-76$ & 84.75 & 46.6 & 1.50 & 0.80 & 2.53 & 68.4 \\
\hline $10 \mathrm{H}-2,75-76$ & 86.25 & 42.1 & 1.63 & 0.94 & 2.85 & 66.9 \\
\hline $10 \mathrm{H}-3,75-76$ & 87.75 & 42.7 & 1.61 & 0.92 & 2.79 & 67.0 \\
\hline $10 \mathrm{H}-4,75-76$ & 89.25 & 39.8 & 1.64 & 0.99 & 2.72 & 63.7 \\
\hline $10 \mathrm{H}-5,75-76$ & 90.75 & 42.4 & 1.63 & 0.94 & 2.90 & 67.6 \\
\hline $10 \mathrm{H}-6,75-76$ & 92.25 & 43.5 & 1.58 & 0.89 & 2.72 & 67.2 \\
\hline $10 \mathrm{H}-7,60-61$ & 93.30 & 40.7 & 1.66 & 0.98 & 2.88 & 65.9 \\
\hline $11 \mathrm{H}-1,75-76$ & 94.25 & 34.8 & 1.74 & 1.13 & 2.77 & 59.1 \\
\hline
\end{tabular}

\begin{tabular}{|c|c|c|c|c|c|c|}
\hline \multirow[b]{2}{*}{$\begin{array}{l}\text { Core, section, } \\
\text { interval }(\mathrm{cm})\end{array}$} & \multirow[b]{2}{*}{$\begin{array}{l}\text { Depth } \\
\text { CSF }(m)\end{array}$} & \multirow{2}{*}{$\begin{array}{l}\text { Water } \\
\text { content } \\
\text { (wt\%) }\end{array}$} & \multicolumn{3}{|c|}{ Density $\left(\mathrm{g} / \mathrm{cm}^{3}\right)$} & \multirow[b]{2}{*}{$\begin{array}{c}\text { Porosity } \\
\text { (\%) }\end{array}$} \\
\hline & & & $\begin{array}{l}\text { Wet } \\
\text { bulk }\end{array}$ & $\begin{array}{l}\text { Dry } \\
\text { bulk }\end{array}$ & Grain & \\
\hline $11 \mathrm{H}-2,75-76$ & 95.75 & 36.9 & 1.70 & 1.07 & 2.77 & 61.2 \\
\hline $11 \mathrm{H}-3,75-76$ & 97.25 & 40.3 & 1.64 & 0.98 & 2.75 & 64.5 \\
\hline $11 \mathrm{H}-4,75-76$ & 98.75 & 39.3 & 1.68 & 1.02 & 2.85 & 64.3 \\
\hline $11 \mathrm{H}-5,75-76$ & 100.25 & 42.3 & 1.61 & 0.93 & 2.77 & 66.5 \\
\hline $11 \mathrm{H}-6,75-76$ & 101.75 & 38.9 & 1.67 & 1.02 & 2.77 & 63.2 \\
\hline $11 \mathrm{H}-7,55-56$ & 103.05 & 37.2 & 1.69 & 1.06 & 2.76 & 61.4 \\
\hline $12 \mathrm{H}-2,75-76$ & 105.25 & 37.5 & 1.70 & 1.06 & 2.81 & 62.2 \\
\hline $12 \mathrm{H}-3,75-76$ & 106.75 & 38.1 & 1.67 & 1.04 & 2.75 & 62.3 \\
\hline $12 \mathrm{H}-4,75-76$ & 108.25 & 38.2 & 1.69 & 1.05 & 2.85 & 63.2 \\
\hline $12 \mathrm{H}-5,75-76$ & 109.75 & 35.4 & 1.73 & 1.12 & 2.78 & 59.7 \\
\hline $12 \mathrm{H}-6,65-66$ & 111.15 & 35.3 & 1.70 & 1.10 & 2.67 & 58.7 \\
\hline $12 \mathrm{H}-7,55-56$ & 112.05 & 37.0 & 1.72 & 1.08 & 2.86 & 62.1 \\
\hline $13 \mathrm{H}-2,75-76$ & 114.75 & 37.5 & 1.69 & 1.06 & 2.79 & 62.1 \\
\hline $13 \mathrm{H}-3,75-76$ & 116.25 & 39.2 & 1.65 & 1.00 & 2.72 & 63.2 \\
\hline $13 \mathrm{H}-4,75-76$ & 117.75 & 35.7 & 1.74 & 1.12 & 2.84 & 60.6 \\
\hline $13 \mathrm{H}-5,75-76$ & 119.25 & 38.7 & 1.68 & 1.03 & 2.85 & 63.7 \\
\hline $13 \mathrm{H}-6,75-76$ & 120.75 & 41.4 & 1.62 & 0.95 & 2.77 & 65.6 \\
\hline $13 \mathrm{H}-7,45-46$ & 121.95 & 35.6 & 1.73 & 1.12 & 2.81 & 60.2 \\
\hline $15 \mathrm{H}-1,75-76$ & 124.25 & 33.7 & 1.78 & 1.18 & 2.86 & 58.7 \\
\hline $15 \mathrm{H}-2,75-76$ & 125.75 & 16.4 & 2.57 & 2.15 & 3.65 & 41.2 \\
\hline $15 \mathrm{H}-3,75-76$ & 127.25 & 38.2 & 1.71 & 1.06 & 2.90 & 63.6 \\
\hline $15 \mathrm{H}-4,75-76$ & 128.75 & 34.3 & 1.77 & 1.16 & 2.87 & 59.4 \\
\hline $15 \mathrm{H}-5,75-76$ & 130.25 & 36.4 & 1.75 & 1.12 & 2.96 & 62.3 \\
\hline $15 \mathrm{H}-6,75-76$ & 131.75 & 32.1 & 1.81 & 1.23 & 2.82 & 56.6 \\
\hline $15 \mathrm{H}-7,50-51$ & 133.00 & 37.6 & 1.71 & 1.07 & 2.85 & 62.6 \\
\hline $16 \mathrm{H}-1,130-131$ & 134.30 & 36.8 & 1.69 & 1.07 & 2.72 & 60.8 \\
\hline $16 \mathrm{H}-2,75-76$ & 135.25 & 35.8 & 1.73 & 1.11 & 2.81 & 60.5 \\
\hline $16 \mathrm{H}-3,75-76$ & 136.75 & 38.1 & 1.68 & 1.04 & 2.78 & 62.6 \\
\hline $16 \mathrm{H}-4,75-76$ & 138.25 & 38.0 & 1.69 & 1.05 & 2.83 & 62.9 \\
\hline $16 \mathrm{H}-5,120-121$ & 140.20 & 35.6 & 1.75 & 1.13 & 2.89 & 60.9 \\
\hline $16 \mathrm{H}-6,75-76$ & 141.25 & 36.1 & 1.72 & 1.10 & 2.81 & 60.8 \\
\hline $17 \mathrm{H}-1,75-76$ & 142.75 & 38.1 & 1.69 & 1.04 & 2.80 & 62.8 \\
\hline $17 \mathrm{H}-2,75-76$ & 144.25 & 34.2 & 1.77 & 1.16 & 2.83 & 59.0 \\
\hline $17 \mathrm{H}-3,75-76$ & 145.75 & 36.8 & 1.70 & 1.08 & 2.78 & 61.3 \\
\hline $17 \mathrm{H}-4,75-76$ & 147.25 & 36.9 & 1.72 & 1.09 & 2.86 & 62.1 \\
\hline $17 \mathrm{H}-5,75-76$ & 148.75 & 34.9 & 1.77 & 1.15 & 2.89 & 60.1 \\
\hline $17 \mathrm{H}-6,75-76$ & 150.25 & 37.6 & 1.71 & 1.07 & 2.86 & 62.7 \\
\hline $17 \mathrm{H}-7,50-51$ & 151.50 & 36.8 & 1.70 & 1.08 & 2.78 & 61.2 \\
\hline $18 \mathrm{H}-1,75-76$ & 152.25 & 39.2 & 1.66 & 1.01 & 2.77 & 63.6 \\
\hline $18 \mathrm{H}-2,75-76$ & 153.75 & 36.3 & 1.71 & 1.09 & 2.75 & 60.5 \\
\hline $18 \mathrm{H}-3,75-76$ & 155.25 & 36.8 & 1.70 & 1.08 & 2.77 & 61.1 \\
\hline $18 \mathrm{H}-4,75-76$ & 156.75 & 34.9 & 1.74 & 1.13 & 2.77 & 59.3 \\
\hline $18 \mathrm{H}-5,75-76$ & 158.25 & 35.6 & 1.71 & 1.10 & 2.72 & 59.5 \\
\hline $18 \mathrm{H}-6,75-76$ & 159.75 & 34.4 & 1.76 & 1.15 & 2.82 & 59.0 \\
\hline $18 \mathrm{H}-7,60-61$ & 161.10 & 34.9 & 1.76 & 1.14 & 2.85 & 59.9 \\
\hline $19 \mathrm{H}-1,75-76$ & 161.75 & 33.8 & 1.78 & 1.18 & 2.85 & 58.7 \\
\hline $19 \mathrm{H}-2,75-76$ & 163.25 & 36.9 & 1.70 & 1.07 & 2.78 & 61.4 \\
\hline $19 \mathrm{H}-3,75-76$ & 164.75 & 37.2 & 1.70 & 1.07 & 2.81 & 62.0 \\
\hline $19 \mathrm{H}-4,75-76$ & 166.25 & 35.0 & 1.73 & 1.12 & 2.74 & 59.0 \\
\hline $19 \mathrm{H}-5,75-76$ & 167.75 & 33.9 & 1.75 & 1.16 & 2.76 & 58.1 \\
\hline $19 \mathrm{H}-6,75-76$ & 169.25 & 33.5 & 1.77 & 1.18 & 2.80 & 57.9 \\
\hline $19 \mathrm{H}-7,30-31$ & 170.30 & 34.2 & 1.75 & 1.15 & 2.76 & 58.4 \\
\hline $20 \mathrm{H}-1,75-76$ & 171.25 & 34.1 & 1.76 & 1.16 & 2.79 & 58.4 \\
\hline $20 \mathrm{H}-3,75-76$ & 174.25 & 36.6 & 1.71 & 1.09 & 2.81 & 61.3 \\
\hline $20 \mathrm{H}-4,75-76$ & 175.75 & 32.8 & 1.81 & 1.22 & 2.90 & 58.1 \\
\hline $20 \mathrm{H}-5,75-76$ & 177.25 & 31.8 & 1.84 & 1.25 & 2.92 & 57.0 \\
\hline $20 \mathrm{H}-6,75-76$ & 178.75 & 33.0 & 1.77 & 1.19 & 2.76 & 57.0 \\
\hline $21 \mathrm{H}-1,75-76$ & 180.75 & 31.0 & 1.81 & 1.25 & 2.77 & 54.8 \\
\hline $21 \mathrm{H}-2,75-76$ & 182.25 & 28.3 & 1.87 & 1.34 & 2.76 & 51.5 \\
\hline $21 \mathrm{H}-3,75-76$ & 183.75 & 29.6 & 1.86 & 1.31 & 2.84 & 53.8 \\
\hline $21 \mathrm{H}-4,34-35$ & 184.34 & 29.0 & 1.84 & 1.30 & 2.72 & 52.1 \\
\hline $22 X-1,72-73$ & 185.52 & 31.3 & 1.92 & 1.32 & 3.20 & 58.8 \\
\hline $22 \mathrm{X}-3,88-89$ & 188.68 & 28.2 & 2.10 & 1.51 & 3.56 & 57.8 \\
\hline $22 X-4,59-60$ & 189.89 & 30.7 & 1.83 & 1.27 & 2.82 & 54.9 \\
\hline $22 X-5,78-79$ & 191.58 & 30.3 & 1.84 & 1.28 & 2.82 & 54.4 \\
\hline $23 X-1,78-79$ & 195.18 & 29.9 & 1.86 & 1.31 & 2.87 & 54.5 \\
\hline $23 \times-2,78-79$ & 196.68 & 27.9 & 1.90 & 1.37 & 2.84 & 51.8 \\
\hline $23 X-3,75-76$ & 198.15 & 28.5 & 2.04 & 1.46 & 3.36 & 56.6 \\
\hline
\end{tabular}


Table T19 (continued).

\begin{tabular}{|c|c|c|c|c|c|c|}
\hline \multirow[b]{2}{*}{$\begin{array}{l}\text { Core, section, } \\
\text { interval }(\mathrm{cm})\end{array}$} & \multirow[b]{2}{*}{$\begin{array}{l}\text { Depth } \\
\text { CSF (m) }\end{array}$} & \multirow{2}{*}{$\begin{array}{l}\text { Water } \\
\text { content } \\
\text { (wt\%) }\end{array}$} & \multicolumn{3}{|c|}{ Density $\left(\mathrm{g} / \mathrm{cm}^{3}\right)$} & \multirow[b]{2}{*}{$\begin{array}{c}\text { Porosity } \\
\text { (\%) }\end{array}$} \\
\hline & & & $\begin{array}{l}\text { Wet } \\
\text { bulk }\end{array}$ & $\begin{array}{l}\text { Dry } \\
\text { bulk }\end{array}$ & Grain & \\
\hline $23 X-4,72-73$ & 199.62 & 29.3 & 1.86 & 1.31 & 2.81 & 53.2 \\
\hline \multicolumn{7}{|l|}{ 320-U1336B- } \\
\hline $1 \mathrm{H}-1,74-76$ & 0.75 & 53.4 & 1.44 & 0.67 & 2.72 & 75.3 \\
\hline $2 \mathrm{H}-2,74-76$ & 4.05 & 37.8 & 1.67 & 1.04 & 2.70 & 61.6 \\
\hline $2 \mathrm{H}-4,74-76$ & 7.05 & 39.9 & 1.64 & 0.99 & 2.75 & 64.0 \\
\hline $2 \mathrm{H}-6,74-76$ & 10.05 & 47.3 & 1.48 & 0.78 & 2.45 & 68.3 \\
\hline $3 \mathrm{H}-2,74-76$ & 13.55 & 43.2 & 1.58 & 0.90 & 2.70 & 66.7 \\
\hline $3 \mathrm{H}-4,74-76$ & 16.55 & 44.3 & 1.57 & 0.87 & 2.72 & 67.9 \\
\hline $3 \mathrm{H}-6,74-76$ & 19.55 & 45.6 & 1.53 & 0.83 & 2.61 & 68.2 \\
\hline $4 \mathrm{H}-2,74-76$ & 23.05 & 42.3 & 1.60 & 0.92 & 2.70 & 66.0 \\
\hline $4 \mathrm{H}-4,74-76$ & 26.05 & 38.1 & 1.67 & 1.03 & 2.72 & 62.1 \\
\hline $4 \mathrm{H}-6,74-76$ & 29.05 & 40.1 & 1.68 & 1.01 & 2.94 & 65.8 \\
\hline $5 \mathrm{H}-2,74-76$ & 32.55 & 49.0 & 1.51 & 0.77 & 2.77 & 72.2 \\
\hline $5 \mathrm{H}-4,74-76$ & 35.55 & 49.4 & 1.49 & 0.75 & 2.66 & 71.7 \\
\hline $5 \mathrm{H}-6,74-76$ & 38.55 & 52.9 & 1.46 & 0.69 & 2.80 & 75.5 \\
\hline $6 \mathrm{H}-2,74-76$ & 42.05 & 47.3 & 1.53 & 0.81 & 2.77 & 70.8 \\
\hline $6 \mathrm{H}-4,74-76$ & 45.05 & 47.3 & 1.52 & 0.80 & 2.68 & 70.1 \\
\hline $6 \mathrm{H}-6,74-76$ & 48.05 & 41.7 & 1.70 & 0.99 & 3.20 & 69.0 \\
\hline 7H-2, 74-76 & 51.55 & 44.6 & 1.57 & 0.87 & 2.77 & 68.5 \\
\hline $7 \mathrm{H}-4,74-76$ & 54.55 & 44.1 & 1.56 & 0.87 & 2.68 & 67.4 \\
\hline $7 \mathrm{H}-6,74-76$ & 57.55 & 45.9 & 1.54 & 0.83 & 2.67 & 68.9 \\
\hline $8 \mathrm{H}-2,74-76$ & 61.05 & 47.9 & 1.51 & 0.79 & 2.68 & 70.6 \\
\hline $8 \mathrm{H}-4,74-76$ & 64.05 & 43.8 & 1.57 & 0.88 & 2.68 & 67.1 \\
\hline $8 \mathrm{H}-6,74-76$ & 67.05 & 44.7 & 1.55 & 0.86 & 2.67 & 67.8 \\
\hline $9 \mathrm{H}-2,68-70$ & 70.49 & 42.6 & 1.60 & 0.92 & 2.77 & 66.8 \\
\hline $9 \mathrm{H}-4,74-76$ & 73.55 & 39.9 & 1.63 & 0.98 & 2.68 & 63.5 \\
\hline $9 \mathrm{H}-6,74-76$ & 76.55 & 40.3 & 1.63 & 0.97 & 2.69 & 64.0 \\
\hline $10 \mathrm{H}-1,74-76$ & 78.55 & 41.1 & 1.63 & 0.96 & 2.77 & 65.4 \\
\hline $10 \mathrm{H}-4,74-76$ & 83.05 & 43.0 & 1.58 & 0.90 & 2.67 & 66.3 \\
\hline
\end{tabular}

\begin{tabular}{|c|c|c|c|c|c|c|}
\hline \multirow[b]{2}{*}{$\begin{array}{l}\text { Core, section, } \\
\text { interval }(\mathrm{cm})\end{array}$} & \multirow[b]{2}{*}{$\begin{array}{l}\text { Depth } \\
\text { CSF (m) }\end{array}$} & \multirow{2}{*}{$\begin{array}{c}\text { Water } \\
\text { content } \\
\text { (wt\%) }\end{array}$} & \multicolumn{3}{|c|}{ Density $\left(\mathrm{g} / \mathrm{cm}^{3}\right)$} & \multirow[b]{2}{*}{$\begin{array}{c}\text { Porosity } \\
\text { (\%) }\end{array}$} \\
\hline & & & $\begin{array}{l}\text { Wet } \\
\text { bulk }\end{array}$ & $\begin{array}{l}\text { Dry } \\
\text { bulk }\end{array}$ & Grain & \\
\hline $10 \mathrm{H}-6,74-76$ & 86.05 & 42.7 & 1.59 & 0.91 & 2.70 & 66.2 \\
\hline $11 \mathrm{H}-2,74-76$ & 89.55 & 48.3 & 1.46 & 0.76 & 2.44 & 69.0 \\
\hline $11 \mathrm{H}-4,74-76$ & 92.55 & 40.3 & 1.62 & 0.97 & 2.69 & 63.9 \\
\hline $11 \mathrm{H}-6,79-81$ & 95.6 & 43.0 & 1.53 & 0.87 & 2.45 & 64.4 \\
\hline $12 \mathrm{H}-2,74-76$ & 99.05 & 43.3 & 1.59 & 0.90 & 2.77 & 67.3 \\
\hline $12 \mathrm{H}-4,74-76$ & 102.05 & 36.3 & 1.69 & 1.08 & 2.69 & 59.9 \\
\hline $12 \mathrm{H}-6,74-76$ & 105.05 & 38.1 & 1.66 & 1.03 & 2.71 & 62.0 \\
\hline $13 \mathrm{H}-2,74-76$ & 108.55 & 42.5 & 1.60 & 0.92 & 2.75 & 66.5 \\
\hline $13 \mathrm{H}-4,74-76$ & 111.55 & 30.9 & 1.87 & 1.29 & 2.99 & 56.6 \\
\hline $13 \mathrm{H}-6,74-76$ & 114.55 & 34.6 & 1.72 & 1.13 & 2.70 & 58.3 \\
\hline $14 \mathrm{H}-2,74-76$ & 118.05 & 42.5 & 1.59 & 0.91 & 2.67 & 65.9 \\
\hline $14 \mathrm{H}-4,72-74$ & 121.03 & 27.2 & 1.88 & 1.37 & 2.73 & 49.9 \\
\hline $15 \mathrm{H}-2,74-76$ & 127.55 & 33.0 & 1.78 & 1.19 & 2.78 & 57.3 \\
\hline $15 \mathrm{H}-4,74-76$ & 130.55 & 39.5 & 1.64 & 0.99 & 2.68 & 63.1 \\
\hline $15 \mathrm{H}-6,74-76$ & 133.55 & 30.7 & 1.80 & 1.25 & 2.70 & 53.9 \\
\hline $16 \mathrm{H}-1,44-46$ & 135.25 & 34.2 & 1.75 & 1.15 & 2.78 & 58.5 \\
\hline $17 \mathrm{H}-2,74-76$ & 139.05 & 36.9 & 1.70 & 1.08 & 2.79 & 61.5 \\
\hline $17 \mathrm{H}-4,74-76$ & 142.05 & 33.1 & 1.75 & 1.17 & 2.70 & 56.6 \\
\hline $17 \mathrm{H}-6,36-38$ & 144.17 & 35.1 & 1.72 & 1.11 & 2.70 & 58.8 \\
\hline $18 \mathrm{H}-2,74-76$ & 147.65 & 36.7 & 1.70 & 1.08 & 2.77 & 61.2 \\
\hline $18 \mathrm{H}-4,74-76$ & 150.65 & 39.5 & 1.63 & 0.99 & 2.67 & 63.0 \\
\hline $18 \mathrm{H}-6,74-76$ & 153.65 & 38.1 & 1.65 & 1.02 & 2.66 & 61.6 \\
\hline $19 \mathrm{H}-2,74-76$ & 157.15 & 36.4 & 1.70 & 1.08 & 2.74 & 60.5 \\
\hline $19 \mathrm{H}-4,74-76$ & 160.15 & 33.2 & 1.75 & 1.17 & 2.69 & 56.7 \\
\hline $19 \mathrm{H}-6,74-76$ & 163.15 & 34.3 & 1.73 & 1.13 & 2.70 & 57.9 \\
\hline $20 \mathrm{H}-2,74-76$ & 166.65 & 32.4 & 1.78 & 1.20 & 2.76 & 56.4 \\
\hline $20 \mathrm{H}-4,74-76$ & 169.65 & 33.6 & 1.74 & 1.16 & 2.70 & 57.1 \\
\hline $20 \mathrm{H}-6,74-76$ & 172.65 & 33.6 & 1.67 & 1.11 & 2.46 & 54.9 \\
\hline
\end{tabular}

Table T20. Split-core $P$-wave velocity measurements, Site U1336. (Continued on next page.)

\begin{tabular}{|c|c|c|c|c|c|c|c|c|c|c|c|c|c|c|}
\hline \multirow{2}{*}{$\begin{array}{l}\text { Core, } \\
\text { section }\end{array}$} & \multirow{2}{*}{$\begin{array}{c}\text { Depth } \\
\text { CSF }(\mathrm{m})\end{array}$} & \multicolumn{3}{|c|}{ Velocity $(\mathrm{m} / \mathrm{s})$} & \multirow{2}{*}{$\begin{array}{l}\text { Core, } \\
\text { section }\end{array}$} & \multirow{2}{*}{$\begin{array}{c}\text { Depth } \\
\text { CSF (m) }\end{array}$} & \multicolumn{3}{|c|}{ Velocity $(\mathrm{m} / \mathrm{s})$} & \multirow{2}{*}{$\begin{array}{l}\text { Core, } \\
\text { section }\end{array}$} & \multirow{2}{*}{$\begin{array}{c}\text { Depth } \\
\text { CSF }(m)\end{array}$} & \multicolumn{3}{|c|}{ Velocity $(\mathrm{m} / \mathrm{s})$} \\
\hline & & $x$-axis & $y$-axis & $z$-axis & & & $x$-axis & $y$-axis & $z$-axis & & & $x$-axis & $y$-axis & $z$-axis \\
\hline \multicolumn{5}{|c|}{ 320-U1336A- } & $4 \mathrm{H}-2$ & 29.84 & 1520 & & & $6 \mathrm{H}-5$ & 53.45 & 1506 & & \\
\hline $1 \mathrm{H}-1$ & 1.30 & 1519 & & & $4 \mathrm{H}-2$ & 29.93 & & 1509 & 1502 & $6 \mathrm{H}-6$ & 54.85 & & & 1507 \\
\hline $1 \mathrm{H}-1$ & 1.39 & & 1493 & 1488 & $4 \mathrm{H}-3$ & 31.37 & & & 1499 & $6 \mathrm{H}-6$ & 54.95 & 1516 & & \\
\hline $1 \mathrm{H}-3$ & 4.33 & 1547 & & & $4 \mathrm{H}-3$ & 31.45 & 1530 & & & $7 \mathrm{H}-1$ & 56.95 & 1507 & & \\
\hline $1 \mathrm{H}-3$ & 4.41 & & 1522 & 1514 & $4 \mathrm{H}-4$ & 32.88 & & 1505 & 1499 & $7 \mathrm{H}-2$ & 58.35 & & 1519 & \\
\hline $1 \mathrm{H}-4$ & 5.83 & 1535 & & & $4 \mathrm{H}-4$ & 32.96 & 1527 & & & $7 \mathrm{H}-2$ & 58.44 & 1526 & & \\
\hline $1 \mathrm{H}-4$ & 5.91 & & 1506 & 1502 & $4 \mathrm{H}-5$ & 34.32 & 1537 & & & $7 \mathrm{H}-3$ & 59.95 & 1554 & & \\
\hline $1 \mathrm{H}-5$ & 7.31 & 1535 & & & $4 \mathrm{H}-5$ & 34.41 & & 1515 & 1515 & $7 \mathrm{H}-4$ & 61.38 & & & 1504 \\
\hline $1 \mathrm{H}-5$ & 7.41 & & 1503 & 1501 & $4 \mathrm{H}-6$ & 35.23 & & 1400 & 1506 & $7 \mathrm{H}-4$ & 61.45 & 1522 & & \\
\hline $2 \mathrm{H}-1$ & 9.34 & & & 1452 & $4 \mathrm{H}-6$ & 35.30 & 1542 & & & $7 \mathrm{H}-5$ & 62.91 & & & 1503 \\
\hline $2 \mathrm{H}-1$ & 9.45 & 1532 & & & $5 \mathrm{H}-1$ & 37.85 & & & 1443 & $7 \mathrm{H}-5$ & 62.98 & 1532 & & \\
\hline $2 \mathrm{H}-2$ & 10.74 & 1551 & & & $5 \mathrm{H}-1$ & 37.95 & 1510 & & & $7 \mathrm{H}-6$ & 64.37 & & & 1506 \\
\hline $2 \mathrm{H}-2$ & 10.93 & & & 1831 & $5 \mathrm{H}-2$ & 39.35 & & 1509 & 1502 & $7 \mathrm{H}-6$ & 64.45 & 1526 & & \\
\hline $2 \mathrm{H}-3$ & 12.31 & 1521 & & & $5 \mathrm{H}-2$ & 39.45 & 1531 & & & $8 \mathrm{H}-1$ & 66.37 & & & 1507 \\
\hline $2 \mathrm{H}-3$ & 12.40 & & 1504 & 1502 & $5 \mathrm{H}-3$ & 40.85 & & & 1502 & $8 \mathrm{H}-1$ & 66.45 & 1511 & & \\
\hline $2 \mathrm{H}-4$ & 13.81 & 1540 & & & $5 \mathrm{H}-3$ & 40.96 & 1512 & & & $8 \mathrm{H}-2$ & 67.87 & & & 1511 \\
\hline $2 \mathrm{H}-4$ & 13.91 & & 1506 & 1494 & $5 \mathrm{H}-4$ & 42.36 & & & 1493 & $8 \mathrm{H}-2$ & 67.95 & 1527 & & \\
\hline $2 \mathrm{H}-5$ & 15.37 & & 1500 & 1494 & $5 \mathrm{H}-4$ & 42.45 & 1516 & & & $8 \mathrm{H}-3$ & 69.38 & & & 1511 \\
\hline $2 \mathrm{H}-5$ & 15.46 & 1540 & & & $5 \mathrm{H}-5$ & 43.86 & & 1509 & 1503 & $8 \mathrm{H}-3$ & 69.45 & 1523 & & \\
\hline $2 \mathrm{H}-6$ & 16.81 & 1529 & & & $5 \mathrm{H}-5$ & 43.95 & 1527 & & & $8 \mathrm{H}-4$ & 70.90 & & 1529 & 1518 \\
\hline $2 \mathrm{H}-6$ & 16.90 & & & 1445 & $5 \mathrm{H}-6$ & 45.35 & & & 1506 & $8 \mathrm{H}-4$ & 70.96 & 1535 & & \\
\hline $3 \mathrm{H}-2$ & 20.16 & 1527 & & & $5 \mathrm{H}-6$ & 45.45 & 1525 & & & $8 \mathrm{H}-5$ & 72.36 & & & 1515 \\
\hline $3 \mathrm{H}-3$ & 21.80 & 1545 & & & $6 \mathrm{H}-1$ & 47.45 & 1513 & & & $8 \mathrm{H}-5$ & 72.44 & 1536 & & \\
\hline $3 \mathrm{H}-3$ & 21.90 & & 1507 & 1503 & $6 \mathrm{H}-2$ & 48.87 & & & 1501 & $9 \mathrm{H}-1$ & 75.96 & 1516 & & \\
\hline $3 \mathrm{H}-4$ & 23.39 & & 1513 & 1503 & $6 \mathrm{H}-2$ & 48.95 & 1520 & & & $9 \mathrm{H}-2$ & 77.37 & & & 1518 \\
\hline $3 \mathrm{H}-4$ & 23.47 & 1546 & & & $6 \mathrm{H}-3$ & 50.45 & 1525 & & & $9 \mathrm{H}-2$ & 77.45 & 1548 & & \\
\hline $3 \mathrm{H}-5$ & 24.86 & & 1510 & 1508 & $6 \mathrm{H}-4$ & 51.86 & & & 1506 & $9 \mathrm{H}-3$ & 78.95 & 1566 & & \\
\hline $3 \mathrm{H}-5$ & 24.95 & 1534 & & & $6 \mathrm{H}-4$ & 51.95 & 1522 & & & $9 \mathrm{H}-4$ & 80.37 & & & 1468 \\
\hline $3 \mathrm{H}-6$ & 26.38 & & & 1497 & $6 \mathrm{H}-5$ & 53.37 & & 1514 & 1499 & $9 \mathrm{H}-4$ & 80.45 & 1538 & & \\
\hline
\end{tabular}


Table T20 (continued).

\begin{tabular}{|c|c|c|c|c|c|c|c|c|c|c|c|c|c|c|}
\hline \multirow{2}{*}{$\begin{array}{l}\text { Core, } \\
\text { section }\end{array}$} & \multirow{2}{*}{$\begin{array}{l}\text { Depth } \\
\text { CSF (m) }\end{array}$} & \multicolumn{3}{|c|}{ Velocity $(\mathrm{m} / \mathrm{s})$} & \multirow{2}{*}{$\begin{array}{c}\text { Core, } \\
\text { section }\end{array}$} & \multirow{2}{*}{$\begin{array}{l}\text { Depth } \\
\text { CSF (m) }\end{array}$} & \multicolumn{3}{|c|}{ Velocity $(\mathrm{m} / \mathrm{s})$} & \multirow{2}{*}{$\begin{array}{l}\text { Core, } \\
\text { section }\end{array}$} & \multirow{2}{*}{$\begin{array}{c}\text { Depth } \\
\text { CSF (m) }\end{array}$} & & ocity (m & \\
\hline & & $x$-axis & $y$-axis & $z$-axis & & & $x$-axis & $y$-axis & $z$-axis & & & $x$-axis & $y$-axis & $z$-axis \\
\hline $9 \mathrm{H}-5$ & 81.95 & 1545 & & & $18 \mathrm{H}-3$ & 155.95 & 1544 & & & $3 \mathrm{H}-2$ & 13.70 & & 1513 & 1498 \\
\hline $9 \mathrm{H}-6$ & 83.34 & & & 1516 & $18 \mathrm{H}-4$ & 157.45 & 1547 & & & $3 \mathrm{H}-2$ & 13.60 & 1585 & & \\
\hline $9 \mathrm{H}-6$ & 83.45 & 1514 & & & $18 \mathrm{H}-5$ & 158.95 & 1541 & & & $3 \mathrm{H}-4$ & 16.73 & & & 1504 \\
\hline $10 \mathrm{H}-1$ & 85.45 & 1530 & & & $18 \mathrm{H}-6$ & 160.45 & 1553 & & & $3 \mathrm{H}-4$ & 16.60 & 1583 & & \\
\hline $10 \mathrm{H}-2$ & 86.85 & & 1407 & & $19 \mathrm{H}-1$ & 162.45 & 1531 & & & $3 \mathrm{H}-6$ & 19.70 & & & 1497 \\
\hline $10 \mathrm{H}-2$ & 86.94 & 1528 & & & $19 \mathrm{H}-2$ & 163.94 & 1566 & & & $3 \mathrm{H}-6$ & 19.60 & 1551 & & \\
\hline $10 \mathrm{H}-3$ & 88.44 & 1554 & & & $19 \mathrm{H}-3$ & 165.45 & 1552 & & & $4 \mathrm{H}-2$ & 23.20 & & & 1499 \\
\hline $10 \mathrm{H}-4$ & 89.95 & 1543 & & & $19 \mathrm{H}-4$ & 166.95 & 1528 & & & $4 \mathrm{H}-2$ & 23.10 & 1557 & & \\
\hline $10 \mathrm{H}-5$ & 91.46 & 1546 & & & $19 \mathrm{H}-5$ & 168.45 & 1566 & & & $4 \mathrm{H}-4$ & 26.20 & & 1509 & 1498 \\
\hline $11 \mathrm{H}-1$ & 94.82 & 1548 & & & $19 \mathrm{H}-6$ & 169.95 & 1560 & & & $4 \mathrm{H}-4$ & 26.10 & 1583 & & \\
\hline $11 \mathrm{H}-1$ & 94.91 & & 1431 & & $20 \mathrm{H}-1$ & 171.94 & 1549 & & & $4 \mathrm{H}-6$ & 29.20 & & 1511 & 1513 \\
\hline $11 \mathrm{H}-2$ & 96.46 & 1557 & & & $20 \mathrm{H}-2$ & 173.45 & 1518 & & & $4 \mathrm{H}-6$ & 29.10 & 1570 & & \\
\hline $11 \mathrm{H}-3$ & 97.96 & 1551 & & & $20 \mathrm{H}-3$ & 174.95 & 1544 & & & $5 \mathrm{H}-2$ & 32.70 & & & 1499 \\
\hline $11 \mathrm{H}-4$ & 99.31 & 1515 & & & $20 \mathrm{H}-4$ & 176.45 & 1560 & & & $5 \mathrm{H}-2$ & 32.60 & 1582 & & \\
\hline $11 \mathrm{H}-4$ & 99.40 & & 1536 & & $20 \mathrm{H}-5$ & 177.95 & 1616 & & & $5 \mathrm{H}-4$ & 35.60 & 1573 & & \\
\hline $11 \mathrm{H}-5$ & 100.82 & 1523 & & & $21 \mathrm{H}-1$ & 181.66 & 1586 & & & $5 \mathrm{H}-6$ & 38.60 & 1588 & & \\
\hline $11 \mathrm{H}-5$ & 100.91 & & 1529 & 1529 & $21 \mathrm{H}-2$ & 182.91 & 1583 & & & $6 \mathrm{H}-2$ & 42.20 & & 1494 & 1496 \\
\hline $11 \mathrm{H}-6$ & 102.31 & 1553 & & & $22 X-1$ & 186.24 & 1698 & & & $6 \mathrm{H}-2$ & 42.10 & 1562 & & \\
\hline $11 \mathrm{H}-6$ & 102.40 & & 1558 & & $22 X-2$ & 187.75 & 1608 & & & $6 \mathrm{H}-4$ & 45.20 & & 1501 & 1502 \\
\hline $12 \mathrm{H}-2$ & 105.94 & 1541 & & & $22 X-3$ & 189.24 & 1683 & & & $6 \mathrm{H}-4$ & 45.30 & 1568 & & \\
\hline $12 \mathrm{H}-3$ & 107.37 & & 1553 & 1530 & $22 X-4$ & 190.66 & 1814 & & & $6 \mathrm{H}-6$ & 47.90 & & 1501 & 1497 \\
\hline $12 \mathrm{H}-3$ & 107.45 & 1522 & & & $22 X-5$ & 191.68 & 1651 & & & $6 \mathrm{H}-6$ & 47.81 & 1549 & & \\
\hline $12 \mathrm{H}-4$ & 108.87 & & & 1534 & $23 X-1$ & 195.85 & 1648 & & & 7H-2 & 51.63 & & 1494 & \\
\hline $12 \mathrm{H}-4$ & 108.95 & 1549 & & & $23 X-2$ & 197.36 & 1902 & & & $7 \mathrm{H}-2$ & 51.71 & 1570 & & \\
\hline $12 \mathrm{H}-5$ & 110.36 & & 1541 & 1532 & $23 X-3$ & 198.85 & 1802 & & & $7 \mathrm{H}-4$ & 54.69 & & 1400 & 1514 \\
\hline $12 \mathrm{H}-5$ & 110.45 & 1551 & & & $23 X-4$ & 200.33 & 1834 & & & $7 \mathrm{H}-4$ & 54.60 & 1555 & & \\
\hline $12 \mathrm{H}-6$ & 111.38 & & 1564 & 1486 & $23 X-5$ & 201.70 & 1890 & & & $7 \mathrm{H}-6$ & 57.61 & 1555 & & \\
\hline $12 \mathrm{H}-6$ & 111.46 & 1548 & & & $24 X-1$ & 203.73 & 1858 & & & $8 \mathrm{H}-2$ & 61.23 & & 1495 & 1494 \\
\hline $13 \mathrm{H}-2$ & 115.44 & 1557 & & & $24 X-2$ & 205.32 & 1891 & & & $8 \mathrm{H}-2$ & 61.12 & 1538 & & \\
\hline $13 \mathrm{H}-3$ & 116.87 & & 1425 & & $24 X-3$ & 206.74 & 1906 & & & $8 \mathrm{H}-4$ & 64.10 & 1564 & & \\
\hline $13 \mathrm{H}-3$ & 116.95 & 1546 & & & $24 X-4$ & 207.47 & 2016 & & & $8 \mathrm{H}-6$ & 66.94 & 1549 & & \\
\hline $13 \mathrm{H}-5$ & 119.86 & & 1403 & & $24 X-4$ & 207.47 & 7377 & & & $9 \mathrm{H}-2$ & 70.70 & 1624 & & \\
\hline $13 \mathrm{H}-5$ & 119.94 & 1537 & & & $25 X-1$ & 213.14 & 2015 & & & $9 \mathrm{H}-4$ & 73.81 & 1550 & & \\
\hline $13 \mathrm{H}-6$ & 121.36 & & 1414 & 1524 & $25 X-2$ & 214.61 & 1853 & & & $9 \mathrm{H}-6$ & 76.60 & 1592 & & \\
\hline $13 \mathrm{H}-6$ & 121.44 & 1529 & & & $25 X-3$ & 215.85 & 1896 & & & $10 \mathrm{H}-2$ & 80.10 & 1574 & & \\
\hline $13 \mathrm{H}-7$ & 122.20 & & 1546 & 1540 & $26 X-1$ & 222.93 & 1959 & & & $10 \mathrm{H}-4$ & 83.10 & 1562 & & \\
\hline $13 \mathrm{H}-7$ & 122.27 & 1549 & & & $26 X-2$ & 224.33 & 2069 & & & $10 \mathrm{H}-6$ & 86.10 & 1549 & & \\
\hline $15 \mathrm{H}-2$ & 126.35 & & & 1479 & $26 X-3$ & 225.97 & 1830 & & & $11 \mathrm{H}-2$ & 89.60 & 1620 & & \\
\hline $15 \mathrm{H}-2$ & 126.44 & 1529 & & & $26 X-4$ & 227.51 & 1963 & & & $11 \mathrm{H}-4$ & 92.60 & 1570 & & \\
\hline $15 \mathrm{H}-3$ & 127.88 & & 1433 & & $26 X-5$ & 228.93 & 1984 & & & $11 \mathrm{H}-6$ & 95.80 & & & 1499 \\
\hline $15 \mathrm{H}-3$ & 127.96 & 1561 & & & $26 X-6$ & 230.08 & 1999 & & & $11 \mathrm{H}-6$ & 95.70 & 1598 & & \\
\hline $15 \mathrm{H}-4$ & 129.36 & & 1448 & 1552 & $27 X-1$ & 232.57 & 2046 & & & $12 \mathrm{H}-2$ & 99.10 & 1560 & & \\
\hline $15 \mathrm{H}-4$ & 129.45 & 1565 & & & $27 X-2$ & 234.00 & 2181 & & & $12 \mathrm{H}-4$ & 102.10 & 1585 & & \\
\hline $15 \mathrm{H}-5$ & 130.83 & 1543 & & & $27 X-3$ & 235.30 & 2121 & & & $12 \mathrm{H}-6$ & 105.20 & & 1413 & \\
\hline $15 \mathrm{H}-5$ & 130.93 & & & 1530 & $27 X-4$ & 236.89 & 2007 & & & $12 \mathrm{H}-6$ & 105.10 & 1593 & & \\
\hline $15 \mathrm{H}-6$ & 132.22 & & 1440 & & $28 X-1$ & 242.27 & 1988 & & & $13 \mathrm{H}-2$ & 108.60 & 1578 & & \\
\hline $15 \mathrm{H}-6$ & 132.37 & & 1549 & & $28 X-2$ & 243.08 & 1847 & & & $13 \mathrm{H}-4$ & 111.69 & 1596 & & \\
\hline $15 \mathrm{H}-6$ & 132.45 & 1544 & & & $29 X-1$ & 251.73 & 2021 & & & $13 \mathrm{H}-6$ & 114.60 & 1591 & & \\
\hline $16 \mathrm{H}-2$ & 135.87 & & 1464 & & $29 X-2$ & 253.20 & 2068 & & & $14 \mathrm{H}-4$ & 120.99 & 1652 & & \\
\hline $16 \mathrm{H}-3$ & 137.34 & & & 1540 & $29 X-3$ & 253.65 & 2184 & & & $15 \mathrm{H}-2$ & 127.60 & 1559 & & \\
\hline $16 \mathrm{H}-3$ & 137.44 & 1539 & & & $30 X-1$ & 261.41 & 2137 & & & $15 \mathrm{H}-4$ & 130.60 & 1549 & & \\
\hline $16 \mathrm{H}-5$ & 140.36 & & 1544 & 1539 & $30 \times-2$ & 262.67 & 2037 & & & $15 \mathrm{H}-6$ & 133.48 & 1576 & & \\
\hline $16 \mathrm{H}-6$ & 141.63 & & 1535 & 1531 & $30 \times-3$ & 263.30 & 2058 & & & 17H-2 & 139.20 & & & 1540 \\
\hline 17H-1 & 143.31 & & & 1483 & $32 X-1$ & 280.53 & 2103 & & & 17H-2 & 139.10 & 1592 & & \\
\hline $17 \mathrm{H}-2$ & 144.87 & & 1563 & & $32 X-2$ & 281.98 & 2066 & & & 17H-4 & 142.20 & & 1466 & \\
\hline 17H-2 & 144.95 & 1561 & & & $32 X-3$ & 282.34 & 2174 & & & $17 \mathrm{H}-4$ & 142.10 & 1573 & & \\
\hline $17 \mathrm{H}-3$ & 146.37 & & 1553 & & $33 X-2$ & 289.35 & 2255 & & & 17H-6 & 144.21 & 1605 & & \\
\hline $17 \mathrm{H}-3$ & 146.45 & 1585 & & & $33 X-2$ & 289.35 & 10391 & & & $18 \mathrm{H}-2$ & 147.70 & 1539 & & \\
\hline $17 \mathrm{H}-4$ & 147.86 & & 1343 & 1540 & $320-U 13$ & $6 \mathrm{~B}-$ & & & & $18 \mathrm{H}-4$ & 150.70 & 1556 & & \\
\hline $17 \mathrm{H}-4$ & 148.09 & 1494 & & & $\begin{array}{c}1 \mathrm{H}-1 \\
20 \mathrm{O}\end{array}$ & 0.80 & 15 & & & $18 \mathrm{H}-6$ & 153.71 & 1550 & & \\
\hline $17 \mathrm{H}-5$ & 149.36 & & & 1542 & $2 \mathrm{H}-2$ & $\begin{array}{l}0.80 \\
4.20\end{array}$ & 15 & 1507 & 1515 & 19H-2 & 157.20 & 1571 & & \\
\hline 17H-5 & 149.44 & 1558 & & & $2 \mathrm{H}-2$ & 4.10 & 1576 & 1301 & 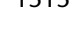 & $19 \mathrm{H}-4$ & 160.20 & 1595 & & \\
\hline 17H-6 & 150.87 & & & 1488 & $\begin{array}{l}2 \mathrm{H}-\mathrm{Z} \\
2 \mathrm{H}-4\end{array}$ & 7.20 & $15 / 0$ & & 1501 & $19 \mathrm{H}-6$ & 163.20 & 1630 & & \\
\hline 17H-6 & 151.11 & 1538 & & & $2 \mathrm{H}-4$ & 7.10 & 1558 & & & $20 \mathrm{H}-2$ & 166.70 & 1622 & & \\
\hline $18 \mathrm{H}-1$ & 152.94 & 1547 & & & $\begin{array}{l}2 \mathrm{H}-4 \\
2 \mathrm{H}-6\end{array}$ & 10.20 & 1508 & & & $20 \mathrm{H}-4$ & 169.70 & 1606 & & \\
\hline $18 \mathrm{H}-2$ & 154.45 & 1555 & & & $\begin{array}{l}2 \mathrm{H}-6 \\
2 \mathrm{H}-6\end{array}$ & 10.20 & 1524 & & 1492 & $20 \mathrm{H}-6$ & 172.70 & 1608 & & \\
\hline
\end{tabular}


Table T21. Thermal conductivity, Site U1336.

\begin{tabular}{crc}
\hline & & \\
$\begin{array}{c}\text { Core, section, } \\
\text { interval (cm) }\end{array}$ & $\begin{array}{c}\text { Depth } \\
\text { CSF }(\mathrm{m})\end{array}$ & $\begin{array}{c}\text { Thermal } \\
\text { conductivity } \\
(\mathrm{W} /[\mathrm{m} \cdot \mathrm{K}])\end{array}$ \\
\hline 320-U1336A- & & \\
$1 \mathrm{H}-3,115$ & 4.15 & 1.210 \\
$2 \mathrm{H}-3,115$ & 12.15 & 1.106 \\
$3 \mathrm{H}-3,115$ & 21.65 & 1.114 \\
$4 \mathrm{H}-3,115$ & 31.15 & 0.911 \\
$5 \mathrm{H}-3,115$ & 40.65 & 1.073 \\
$6 \mathrm{H}-3,115$ & 50.15 & 0.994 \\
$7 \mathrm{H}-3,115$ & 59.65 & 1.061 \\
$8 \mathrm{H}-3,115$ & 69.15 & 1.110 \\
$9 \mathrm{H}-3,115$ & 78.65 & 1.132 \\
$10 \mathrm{H}-3,115$ & 88.15 & 1.100 \\
$11 \mathrm{H}-3,115$ & 97.65 & 1.186 \\
$12 \mathrm{H}-3,115$ & 107.15 & 1.256 \\
$13 \mathrm{H}-3,115$ & 116.65 & 1.209 \\
$15 \mathrm{H}-3,115$ & 127.65 & 1.228 \\
$16 \mathrm{H}-3,115$ & 137.15 & 1.228 \\
$17 \mathrm{H}-3,115$ & 146.15 & 1.209 \\
$18 \mathrm{H}-3,115$ & 155.65 & 1.202 \\
$19 \mathrm{H}-3,115$ & 165.13 & 1.286 \\
$20 \mathrm{H}-3,115$ & 174.65 & 1.314 \\
$21 \mathrm{H}-2,115$ & 182.65 & 1.375 \\
$22 \mathrm{X}-3,115$ & 188.95 & 1.209 \\
$320-\mathrm{U} 1336 \mathrm{~B}-$ & & \\
$2 \mathrm{H}-4,75$ & 7.05 & 1.335 \\
$3 \mathrm{H}-4,75$ & 16.55 & 1.136 \\
$4 \mathrm{H}-4,75$ & 26.05 & 1.281 \\
$5 \mathrm{H}-4,75$ & 35.55 & 0.986 \\
$6 \mathrm{H}-4,75$ & 45.05 & 1.051 \\
$7 \mathrm{H}-4,75$ & 54.55 & 1.163 \\
$8 \mathrm{H}-4,75$ & 64.05 & 1.106 \\
$9 \mathrm{H}-4,75$ & 73.55 & 1.366 \\
$10 \mathrm{H}-4,75$ & 83.05 & 1.211 \\
$11 \mathrm{H}-4,75$ & 92.55 & 1.008 \\
$12 \mathrm{H}-4,75$ & 102.05 & 1.311 \\
$13 \mathrm{H}-4,75$ & 111.55 & 1.708 \\
$14 \mathrm{H}-4,75$ & 121.05 & 1.084 \\
$15 \mathrm{H}-4,75$ & 130.55 & 1.332 \\
$17 \mathrm{H}-4,75$ & 142.05 & 1.335 \\
$18 \mathrm{H}-4,75$ & 150.65 & 1.164 \\
$19 \mathrm{H}-4,75$ & 160.15 & 1.309 \\
$20 \mathrm{H}-4,75$ & 169.65 & 1.360 \\
\hline & &
\end{tabular}


Table T22. Shipboard core top, composite, and corrected composite depths, Site U1336.

\begin{tabular}{|c|c|c|c|c|}
\hline \multirow[b]{2}{*}{ Core } & \multirow{2}{*}{$\begin{array}{l}\text { Depth } \\
\text { CSF }(\mathrm{m})\end{array}$} & \multirow{2}{*}{$\begin{array}{l}\text { Offset } \\
(\mathrm{m})\end{array}$} & \multicolumn{2}{|c|}{ Top depth $(\mathrm{m})$} \\
\hline & & & CCSF-A & CCSF-B \\
\hline \multicolumn{5}{|c|}{ 320-U1336A- } \\
\hline $1 \mathrm{H}$ & 0.00 & 0.26 & 0.26 & 0.23 \\
\hline $2 \mathrm{H}$ & 8.00 & 1.51 & 9.51 & 8.41 \\
\hline $3 \mathrm{H}$ & 17.50 & 1.83 & 19.33 & 17.11 \\
\hline $4 \mathrm{H}$ & 27.00 & 2.80 & 29.80 & 26.37 \\
\hline $5 \mathrm{H}$ & 36.50 & 3.28 & 39.78 & 35.21 \\
\hline $6 \mathrm{H}$ & 46.00 & 6.64 & 52.64 & 46.58 \\
\hline $7 \mathrm{H}$ & 55.50 & 8.04 & 63.54 & 56.23 \\
\hline $8 \mathrm{H}$ & 65.00 & 9.09 & 74.09 & 65.56 \\
\hline $9 \mathrm{H}$ & 74.50 & 9.77 & 84.27 & 74.58 \\
\hline $10 \mathrm{H}$ & 84.00 & 9.71 & 93.71 & 82.93 \\
\hline $11 \mathrm{H}$ & 93.50 & 11.79 & 105.29 & 93.18 \\
\hline $12 \mathrm{H}$ & 103.00 & 12.88 & 115.88 & 102.55 \\
\hline $13 \mathrm{H}$ & 112.50 & 14.22 & 126.72 & 112.14 \\
\hline $14 \mathrm{H}$ & 122.00 & 15.73 & 137.73 & 121.89 \\
\hline $15 \mathrm{H}$ & 123.50 & 16.23 & 139.73 & 123.66 \\
\hline $16 \mathrm{H}$ & 133.00 & 21.50 & 154.50 & 136.72 \\
\hline $17 \mathrm{H}$ & 142.00 & 23.41 & 165.41 & 146.38 \\
\hline $18 \mathrm{H}$ & 151.50 & 23.41 & 174.91 & 154.79 \\
\hline $19 \mathrm{H}$ & 161.00 & 23.41 & 184.41 & 163.19 \\
\hline $20 \mathrm{H}$ & 170.50 & 23.41 & 193.91 & 171.60 \\
\hline $21 \mathrm{H}$ & 180.00 & 23.41 & 203.41 & 180.01 \\
\hline $22 x$ & 184.80 & 23.41 & 208.21 & 184.26 \\
\hline $23 x$ & 194.40 & 23.41 & 217.81 & 192.75 \\
\hline $24 X$ & 202.40 & 23.41 & 225.81 & 199.83 \\
\hline $25 x$ & 212.00 & 23.41 & 235.41 & 208.33 \\
\hline $26 x$ & 221.60 & 23.41 & 245.01 & 216.82 \\
\hline $27 X$ & 231.20 & 23.41 & 254.61 & 225.32 \\
\hline $28 \mathrm{X}$ & 240.80 & 23.41 & 264.21 & 233.81 \\
\hline $29 x$ & 250.40 & 23.41 & 273.81 & 242.31 \\
\hline $30 x$ & 260.00 & 23.41 & 283.41 & 250.81 \\
\hline $31 x$ & 269.60 & 23.41 & 293.01 & 259.30 \\
\hline $32 x$ & 279.20 & 23.41 & 302.61 & 267.80 \\
\hline $33 x$ & 288.80 & 23.41 & 312.21 & 276.29 \\
\hline $34 X$ & 293.80 & 23.41 & 317.21 & 280.72 \\
\hline $35 x$ & 298.30 & 23.41 & 321.71 & 284.70 \\
\hline \multicolumn{5}{|c|}{ 320-U1336B- } \\
\hline $1 \mathrm{H}$ & 0.00 & 0.00 & 0.00 & 0.00 \\
\hline $2 \mathrm{H}$ & 1.80 & 0.53 & 2.33 & 2.06 \\
\hline $3 \mathrm{H}$ & 11.30 & 2.56 & 13.86 & 12.27 \\
\hline $4 \mathrm{H}$ & 20.80 & 4.18 & 24.98 & 22.11 \\
\hline $5 \mathrm{H}$ & 30.30 & 5.58 & 35.88 & 31.75 \\
\hline $6 \mathrm{H}$ & 39.80 & 7.53 & 47.33 & 41.89 \\
\hline $7 \mathrm{H}$ & 49.30 & 8.69 & 57.99 & 51.32 \\
\hline $8 \mathrm{H}$ & 58.80 & 8.88 & 67.68 & 59.90 \\
\hline $9 \mathrm{H}$ & 68.30 & 8.81 & 77.11 & 68.24 \\
\hline $10 \mathrm{H}$ & 77.80 & 10.19 & 87.99 & 77.86 \\
\hline $11 \mathrm{H}$ & 87.30 & 10.69 & 97.99 & 86.72 \\
\hline $12 \mathrm{H}$ & 96.80 & 12.51 & 109.31 & 96.73 \\
\hline $13 \mathrm{H}$ & 106.30 & 14.26 & 120.56 & 106.69 \\
\hline $14 \mathrm{H}$ & 115.80 & 16.98 & 132.78 & 117.50 \\
\hline $15 \mathrm{H}$ & 125.30 & 17.79 & 143.09 & 126.62 \\
\hline $16 \mathrm{H}$ & 134.80 & 17.79 & 152.59 & 135.03 \\
\hline $17 \mathrm{H}$ & 136.80 & 17.79 & 154.59 & 136.80 \\
\hline $18 \mathrm{H}$ & 145.40 & 17.79 & 163.19 & 144.41 \\
\hline $19 \mathrm{H}$ & 154.90 & 17.79 & 172.69 & 152.82 \\
\hline $20 \mathrm{H}$ & 164.40 & 17.79 & 182.19 & 161.23 \\
\hline
\end{tabular}


Table T23. Splice tie points, Site U1336.

\begin{tabular}{|c|c|c|c|c|c|c|}
\hline \multirow{2}{*}{$\begin{array}{l}\text { Hole, core, section, } \\
\text { interval }(\mathrm{cm})\end{array}$} & \multicolumn{2}{|c|}{ Depth } & & \multirow{2}{*}{$\begin{array}{l}\text { Hole, core, section, } \\
\text { interval }(\mathrm{cm})\end{array}$} & \multicolumn{2}{|c|}{ Depth } \\
\hline & CSF & CCSF-A & & & CSF & CCSF-A \\
\hline $320-$ & & & & $320-$ & & \\
\hline U1336B-1H-1, 55 & 0.55 & 0.55 & Tie to & U1336A-1H-1, 29 & 0.29 & 0.55 \\
\hline U1336A-1H-5, 78 & 6.78 & 7.04 & Tie to & U1336B-2H-4, 21 & 6.51 & 7.04 \\
\hline U1336B-2H-7, 26 & 11.06 & 11.59 & Tie to & U1336A-2H-2, 58 & 10.08 & 11.59 \\
\hline U1336A-2H-6, 109 & 16.59 & 18.09 & Tie to & U1336B-3H-3, 123 & 15.53 & 18.09 \\
\hline U1336B-3H-7, 5 & 20.35 & 22.91 & Tie to & U1336A-3H-3, 58 & 21.08 & 22.91 \\
\hline U1336A-3H-6, 54 & 25.54 & 27.38 & Tie to & U1336B-4H-2, 90 & 23.20 & 27.38 \\
\hline U1336B-4H-6, 137 & 29.67 & 33.85 & Tie to & U1336A-4H-3, 105 & 31.05 & 33.85 \\
\hline U1336A-4H-7, 11 & 35.42 & 38.22 & Tie to & U1336B-5H-2, 84 & 32.64 & 38.22 \\
\hline U1336B-5H-6, 126 & 39.06 & 44.64 & Tie to & U1336A-5H-4, 36 & 41.36 & 44.64 \\
\hline U1336A-5H-6, 135 & 45.35 & 48.63 & Tie to & U1336B-6H-1, 130 & 41.10 & 48.63 \\
\hline U1336B-6H-6, 148 & 48.78 & 56.31 & Tie to & U1336A-6H-3, 67 & 49.67 & 56.31 \\
\hline U1336A-6H-6, 131 & 54.81 & 61.45 & Tie to & U1336B-7H-3, 46 & 52.76 & 61.45 \\
\hline U1336B-7H-7, 14 & 58.14 & 66.83 & Tie to & U1336A-7H-3, 29 & 58.79 & 66.83 \\
\hline U1336A-7H-7, 43 & 64.93 & 72.97 & Tie to & U1336B-8H-4, 79 & 64.09 & 72.97 \\
\hline U1336B-8H-6, 9 & 66.39 & 75.27 & Tie to & U1336A-8H-1, 119 & 66.19 & 75.27 \\
\hline U1336A-8H-7, 56 & 73.56 & 82.64 & Tie to & U1336B-9H-4, 103 & 73.83 & 82.64 \\
\hline U1336B-9H-7, 6 & 77.06 & 85.88 & Tie to & U1336A-9H-2, 11 & 76.11 & 85.88 \\
\hline U1336A-9H-4, 104 & 80.04 & 89.81 & Tie to & U1336B-10H-2, 33 & 79.63 & 89.81 \\
\hline U1336B-10H-6, 125 & 86.55 & 96.74 & Tie to & U1336A-10H-2, 153 & 87.03 & 96.74 \\
\hline U1336A-10H-6, 94 & 92.44 & 102.14 & Tie to & U1336B-11H-3, 115 & 91.45 & 102.14 \\
\hline U1336B-11H-6, 82 & 95.62 & 106.31 & Tie to & U1336A-11H-1, 102 & 94.52 & 106.31 \\
\hline U1336A-11H-4, 54 & 98.54 & 110.34 & Tie to & U1336B-12H-1, 103 & 97.83 & 110.34 \\
\hline U1336B-12H-6, 112 & 105.42 & 117.93 & Tie to & U1336A-12H-2, 55 & 105.05 & 117.93 \\
\hline U1336A-12H-4, 121 & 108.71 & 121.59 & Tie to & U1336B-13H-1, 103 & 107.33 & 121.59 \\
\hline U1336B-13H-6, 90 & 114.70 & 128.97 & Tie to & U1336A-13H-2, 75 & 114.75 & 128.97 \\
\hline U1336A-13H-6, 62 & 120.62 & 134.84 & Tie to & U1336B-14H-2, 56 & 117.86 & 134.84 \\
\hline U1336B-14H-7, 66 & 125.46 & 142.44 & Append to & U1336B-15H-1, 0 & 125.30 & 143.09 \\
\hline U1336B-15H-2, 67 & 127.47 & 145.25 & Tie to & U1336A-15H-4, 102 & 129.02 & 145.25 \\
\hline U1336A-15H-7, 61 & 133.11 & 149.35 & Append to & U1336A-16H-1, 5 & 133.05 & 154.55 \\
\hline U1336A-16H-3, 121 & 137.21 & 158.71 & Tie to & U1336B-17H-3, 112 & 140.92 & 158.71 \\
\hline U1336B-17H-7, 79 & 145.29 & 163.07 & Append to & U1336B-18H-1, 0 & 145.40 & 163.19 \\
\hline U1336B-18H-7, 15 & 154.55 & 172.33 & Tie to & U1336A-17H-5, 92 & 148.92 & 172.33 \\
\hline U1336A-17H-7, 58 & 151.58 & 174.99 & Append & & & \\
\hline
\end{tabular}


Table T24. Magnetostratigraphic and biostratigraphic datums, Site U1336. (See table note.) (Continued on next page.)

\begin{tabular}{|c|c|c|c|}
\hline Event & $\begin{array}{l}\text { Age } \\
(\mathrm{Ma})\end{array}$ & $\begin{array}{l}\text { Depth } \\
\text { CCSF-A } \\
(\mathrm{m})\end{array}$ & $\begin{array}{l}\text { Error } \\
\text { (m) }\end{array}$ \\
\hline \multicolumn{4}{|l|}{ Polarity chron } \\
\hline C5r.3r/C5An.1n & 12.014 & 0.55 & \\
\hline C5An.1n/C5An.1r & 12.116 & 1.45 & \\
\hline C5An.1r/C5An.2n & 12.207 & 2.19 & \\
\hline C5An.2n/C5Ar.1r & 12.415 & 5.19 & \\
\hline C5Ar.1r/C5Ar.1n & 12.730 & 7.99 & \\
\hline C5Ar. $1 \mathrm{n} / \mathrm{C} 5$ Ar. $2 \mathrm{r}$ & 12.765 & 8.46 & \\
\hline C5Ar.2r/C5Ar.2n & 12.820 & 9.00 & \\
\hline C5Ar.2n/C5Ar.3r & 12.878 & 9.38 & \\
\hline C5Ar.3r/C5AAn & 13.015 & 10.90 & \\
\hline C5AAn/C5AAr & 13.183 & 12.36 & \\
\hline C5AAr/C5ABn & 13.369 & 14.18 & \\
\hline $\mathrm{C} 5 \mathrm{ABr} / \mathrm{C} 5 \mathrm{ACn}$ & 13.734 & 19.38 & \\
\hline $\mathrm{C} 5 \mathrm{ADn} / \mathrm{C} 5 \mathrm{ADr}$ & 14.581 & 30.21 & \\
\hline C5ADr/C5Bn.1n & 14.784 & 32.05 & \\
\hline C5Bn.1n/C5Bn.1r & 14.877 & 33.56 & \\
\hline C5Bn.1r/C5Bn.2n & 15.032 & 34.84 & \\
\hline $\mathrm{C} 5 \mathrm{Bn} \cdot 2 \mathrm{n} / \mathrm{C} 5 \mathrm{Br}$ & 15.160 & 35.16 & \\
\hline $\mathrm{C} 5 \mathrm{Br} / \mathrm{C} 5 \mathrm{Cn} .1 \mathrm{n}$ & 15.974 & 45.01 & \\
\hline C5Cn.1n/C5Cn.1r & 16.268 & 46.13 & \\
\hline C5Cn.1r/C5Cn.2n & 16.303 & 46.13 & \\
\hline $\mathrm{C} 5 \mathrm{Cn} \cdot 2 \mathrm{n} / \mathrm{C} 5 \mathrm{Cn} \cdot 2 \mathrm{r}$ & 16.472 & 46.99 & \\
\hline C5Cn.2r/C5Cn.3n & 16.543 & 47.79 & \\
\hline $\mathrm{C} 5 \mathrm{Cn} .3 \mathrm{n} / \mathrm{C} 5 \mathrm{Cr}$ & 16.721 & 48.60 & \\
\hline $\mathrm{C} 5 \mathrm{Cr} / \mathrm{C} 5 \mathrm{Dn}$ & 17.235 & 52.83 & \\
\hline $\mathrm{C} 5 \mathrm{Dn} / \mathrm{C} 5 \mathrm{Dr}$ & 17.533 & 56.99 & \\
\hline C5Dr/C5En & 18.056 & 59.58 & \\
\hline C5En/C5Er & 18.524 & 64.39 & \\
\hline C5Er/C6n & 18.748 & 65.83 & \\
\hline \multicolumn{4}{|l|}{ Nannofossils } \\
\hline T Coronocyclus nitescens & 12.12 & 1.36 & \\
\hline T Calcidiscus premacintyrei & 12.45 & 1.36 & \\
\hline Tc Cyclicargolithus floridanus & 13.33 & 16.31 & 1.50 \\
\hline T Sphenolithus heteromorphus & 13.53 & 20.46 & 1.27 \\
\hline Tc Discoaster deflandrei & 15.66 & 33.70 & 1.50 \\
\hline B Discoaster petaliformis & 15.70 & 46.28 & 1.36 \\
\hline Bc Sphenolithus heteromorphus & 17.71 & 66.30 & 0.76 \\
\hline Tc Sphenolithus belemnos & 17.95 & 66.30 & 0.76 \\
\hline T Triquetrorhabdulus carinatus & 18.28 & 66.30 & 0.76 \\
\hline B Sphenolithus belemnos & 19.03 & 84.14 & 0.68 \\
\hline Tc Triquetrorhabdulus carinatus & 22.09 & 135.81 & 0.99 \\
\hline B Sphenolithus disbelemnos & 22.8 & 153.25 & 3.64 \\
\hline T Sphenolithus delphix & 23.1 & 169.31 & 1.50 \\
\hline B Sphenolithus delphix & 23.2 & 174.53 & 0.72 \\
\hline T Sphenolithus ciperoensis & 24.4 & 202.23 & 1.32 \\
\hline X T. longus/T. carinatus & 24.7 & 202.23 & 1.32 \\
\hline Tc Cyclicargolithus abisectus & 24.7 & 191.86 & 0.75 \\
\hline T Sphenolithus distentus & 26.8 & 228.24 & 1.31 \\
\hline T Sphenolithus predistentus & 26.9 & 230.94 & 1.40 \\
\hline B Sphenolithus ciperoensis & 27.1 & 232.69 & 0.34 \\
\hline B Sphenolithus distentus & 30.0 & 277.57 & 0.36 \\
\hline T Reticulofenestra umbilicus & 32.0 & 319.77 & 2.29 \\
\hline \multicolumn{4}{|l|}{ Radiolarians } \\
\hline B Diartus petterssoni & 12.11 & 7.12 & 1.33 \\
\hline B Cyrtocapsella japonica & 12.41 & 7.12 & 1.33 \\
\hline B Lithopera neotera & 12.95 & 10.25 & 1.80 \\
\hline T Calocycletta robusta & 13.35 & 20.53 & 1.35 \\
\hline T Stichocorys armata & 13.50 & 20.53 & 1.35 \\
\hline T Acrocubus octopyle & 13.88 & 23.38 & 1.50 \\
\hline T Calocycletta costata & 14.23 & 27.09 & 2.21 \\
\hline $\mathrm{T}$ Dorcadospyris dentata & 14.66 & 32.81 & 2.54 \\
\hline T Liriospyris stauropora & 14.83 & 32.81 & 2.54 \\
\hline D. dentata $>$ D. alata & 14.78 & 32.81 & 2.54 \\
\hline B Dorcadospyris alata & 15.08 & 40.67 & 1.67 \\
\hline B Liriospyris parkerae & 15.03 & 40.67 & 1.67 \\
\hline T Carpocanopsis cingulata & 15.13 & 47.51 & 2.18 \\
\hline
\end{tabular}


Table T24 (continued).

\begin{tabular}{|c|c|c|c|}
\hline Event & $\begin{array}{l}\text { Age } \\
(\mathrm{Ma})\end{array}$ & $\begin{array}{l}\text { Depth } \\
\text { CCSF-A } \\
(\mathrm{m})\end{array}$ & $\begin{array}{c}\text { Error } \\
(\mathrm{m})\end{array}$ \\
\hline T Lychnocanoma elongata & 15.15 & 55.20 & 0.01 \\
\hline B Lithopera renzae & 16.77 & 55.20 & 0.01 \\
\hline B Calocycletta costata & 17.49 & 58.49 & 3.29 \\
\hline B Dorcadospyris dentata & 17.72 & 63.93 & 2.15 \\
\hline B Liriospyris stauropora & 17.72 & 63.93 & 2.15 \\
\hline T Dorcadospyris scambos & 18.53 & 71.37 & 2.28 \\
\hline B Stichocorys wolffii & 18.57 & 78.14 & 1.50 \\
\hline B Dorcadospyris forcipata & 18.61 & 78.14 & 1.50 \\
\hline T Dorcadospyris simplex s.s. & 18.69 & 85.14 & 1.68 \\
\hline T Dorcadospyris praeforcipata & 19.77 & 95.32 & 0.95 \\
\hline B Dorcadospyris simplex s.s. & 20.34 & 101.37 & 2.12 \\
\hline B Stichocorys delmontensis & 20.68 & 109.34 & 1.50 \\
\hline T Lophocyrtis pegetrum & 20.89 & 113.06 & 2.22 \\
\hline T Theocyrtis annosa & 21.38 & 119.93 & 1.50 \\
\hline B Calocycletta virginis & 21.39 & 116.85 & 1.58 \\
\hline T Eucyrtidium mitodes & 21.95 & 134.53 & 2.27 \\
\hline B Calocycletta serrata & 22.04 & 143.78 & 1.50 \\
\hline B Cyrtocapsella cornuta & 22.26 & 147.45 & 2.16 \\
\hline B Cyrtocapsella tetrapera & 22.35 & 147.45 & 2.16 \\
\hline T Artophormis gracilis & 22.62 & 157.55 & 2.50 \\
\hline B Eucyrtidium diaphanes & 22.95 & 165.72 & 2.24 \\
\hline T Dorcadospyris cyclacantha & 22.98 & 165.72 & 2.24 \\
\hline B Dorcadospyris cyclacantha & 23.29 & 169.46 & 1.50 \\
\hline T Dorcadospyris papilio & 23.31 & 173.11 & 2.14 \\
\hline T Liriospyris longicornuta & 24.12 & 178.96 & 1.51 \\
\hline \multicolumn{4}{|l|}{ Foraminifers } \\
\hline T Globorotalia (Fohsella) fohsi s.l. & 11.79 & 1.95 & 1.69 \\
\hline B Globorotalia (Fohsella) fohsi robusta & 13.13 & 6.04 & 2.41 \\
\hline B Globorotalia (Fohsella) fohsi s.I. & 13.41 & 20.36 & 0.85 \\
\hline B Globorotalia (Fohsella) "praefohsi" & 13.77 & 23.46 & 2.25 \\
\hline T Clavatorella bermudezi & 13.82 & 23.46 & 2.25 \\
\hline T Globorotalia (Fohsella) peripheroronda & 13.80 & 27.51 & 1.80 \\
\hline B Globorotalia (Fohsella) peripheroacuta & 14.24 & 31.73 & 1.46 \\
\hline B Orbulina spp. & 14.74 & 27.51 & 1.80 \\
\hline B Clavatorella bermudezi & 14.89 & 31.73 & 1.46 \\
\hline T Praeorbulina glomerosa & 14.8 & 31.73 & 1.46 \\
\hline T Praeorbulina circularis & 14.58 & 34.68 & 1.50 \\
\hline B Praeorbulina glomerosa & 16.27 & 53.78 & 0.73 \\
\hline B Praeorbulina sicana & 16.97 & 53.78 & 0.73 \\
\hline T Globoquadrina binaiensis & 19.09 & 77.47 & 1.50 \\
\hline T Paragloborotalia kugleri & 21.12 & 106.33 & 0.76 \\
\hline T Paragloborotalia pseudokugleri & 21.31 & 106.33 & 0.76 \\
\hline B Globoquadrina dehiscens & 22.44 & 143.11 & 1.50 \\
\hline B Paragloborotalia kugleri & 23.00 & 166.35 & 0.94 \\
\hline B Paragloborotalia pseudokugleri & 25.2 & 194.90 & 0.89 \\
\hline T Paragloborotalia opima & 26.9 & 228.14 & 2.58 \\
\hline Tc Chiloguembelina cubensis & 28.00 & 238.84 & 1.48 \\
\hline B Globigerina angulisuturalis & 29.2 & 263.35 & 2.56 \\
\hline T Subbotina angiporoides & 29.8 & 270.73 & 4.82 \\
\hline T Turborotalia ampliapertura & 30.3 & 281.61 & 3.68 \\
\hline B Paragloborotalia opima & 30.8 & 281.61 & 3.68 \\
\hline
\end{tabular}

Note: $\mathrm{T}=$ top, $\mathrm{Tc}=$ top common, $\mathrm{B}=$ bottom, $\mathrm{BC}=$ bottom common, $\mathrm{X}=$ abundance crossover. 